Fernando Henrique de Oliveira Biolcati

\title{
Requisitos para a realização de pesquisas clínicas com menores incapazes e a responsabilidade civil no caso de danos
}

Dissertação apresentada ao programa de Pósgraduação Stricto Sensu do Departamento de Direito Civil, da Faculdade de Direito do Largo São Francisco da Universidade de São Paulo, para obtenção do título de Mestre.

Área de concentração: Direito Civil

Orientador: Professor Titular Doutor Fernando Campos Scaff

Universidade de São Paulo

Faculdade de Direito do Largo São Francisco

São Paulo

2012 
Nome: BIOLCATI, Fernando Henrique de Oliveira.

Titulo: Requisitos para a realização de pesquisas clínicas com menores incapazes e a responsabilidade civil no caso de danos.

Aprovado em:

Banca Examinadora

Prof. Dr.

Instituição:

Julgamento:

Assinatura:

Prof. Dr.

Instituição:

Julgamento:

Assinatura:

Prof. Dr.

Instituição:

Julgamento:

Assinatura: 
A meus pais, Jacira e Waldman, pelo apoio perene e inabalável.

A minha avó Walkíria, inspiração de vida.

A Patrícia, simplesmente fundamental. 


\section{AGRADECIMENTOS}

Inúmeras pessoas contribuíram indiretamente ao presente trabalho. Assim, não posso deixar de dizer muito obrigado aos meus irmãos queridos, "mãedrasta", tios, primos, sobrinhos, cunhados, sogros, amigos, de Araçatuba, da Faculdade de Direito, e de São Paulo, de um modo geral.

Já outras pessoas, especificamente, tiveram uma imediata e grande influência na presente dissertação, e por isso mais do que o desejo em agradecê-las, tenho o dever de fazê-lo nominalmente.

A meu orientador, Fernando Campos Scaff, que desde o início confiou na minha competência e me guiou, de maneira cuidadosa, entre os caminhos acadêmicos, com sabedoria, honestidade e sinceridade.

Ao Professor João Alberto Schützer Del Nero, meu mestre na época da graduação e orientador na Tese de Láurea, e que fez despertar em mim, através de sua grande dedicação à docência, e habilidade no desempenho desta, o desejo de estudar mais profundamente o Direito Civil. Além disso, agradeço sua participação em minha banca de qualificação e as sugestões e críticas naquela oportunidade tecidas, certeiras e muito úteis na continuação da pesquisa e elaboração do trabalho final.

À Professora Teresa Ancona Lopez, também integrante da minha banca de qualificação, que, com seu bom humor, carinho e inteligência, ofereceu apontamentos de muita valia para a condução da presente dissertação.

Aos meus pais, tão amados, que me deram todo o suporte, sobretudo afetivo, para que eu pudesse realizar meu sonho de cursar a Faculdade de Direito do Largo São Francisco e continuar nos estudos acadêmicos.

À Patrícia, incentivadora e crítica do presente trabalho, com seus contrapontos cirúrgicos, extremamente úteis para uma reflexão mais ponderada sobre certos posicionamentos.

À Márcia, minha cunhada, por realizar a revisão final desta dissertação de modo bastante acurado, com valiosas lições e sugestões. 


\section{RESUMO}

Este trabalho tem por escopo analisar o procedimento de experimentação de novos tratamentos médicos e farmacêuticos em seres humanos, mais especificamente, crianças e adolescentes. A partir da ideia da condição do menor de pessoa em formação e da proteção especial garantida pela ordem jurídica, busca-se, constatando a necessidade de realização de pesquisas clínicas com este grupo, analisar de que modo a doutrina dos denominados direitos humanos e fundamentais e a regulamentação bioética devem atuar no sentido de estabelecer normativamente os requisitos que garantam o desenvolvimento científico sem o sacrifício das prerrogativas humanas mais comezinhas, como a integridade física e psíquica, bem como a autonomia. Por fim, tendo em vista os conceitos de risco e precaução, são estabelecidos os pressupostos para o nascimento da responsabilidade civil, de pesquisadores, patrocinadores e responsáveis legais pelo menor, inclusive pais, com a abordagem, também, dos reflexos no poder familiar, quando eventuais danos venham a ser produzidos contra as crianças e adolescentes sujeitos de pesquisa.

Palavras-chave: pesquisas clínicas; crianças e adolescentes; bioética; direito à saúde; direitos humanos e fundamentais; risco e precaução; responsabilidade civil. 


\begin{abstract}
This work has as scope the analysis of the procedure regarding new medical and pharmaceutical treatments' testing in humans, more specifically children and teenagers. From the idea of the minor's status as person under development and the special protection guaranteed by law, it is intended with this work, considering the need of clinical researches involving this group, an examination of how the so-called human and fundamental rights as well as bioethics' regulation must act to standardize the requirements that ensure the scientific development without sacrificing the most basic human prerogatives, such as physic and psychological integrity and independence. Finally, in view of risk and precaution's concepts, the assumptions are set to the arise of researchers, sponsors and guardians' liability, including parents, also regarding the repercussion of such liability on parental authority, in the event of damages' occurrence in children and teenagers in the context of clinical trials.
\end{abstract}

Keywords: clinical research; children and teenagers; bioethics; health law; human and fundamental rights; risk and precaution; liability. 


\section{SUMÁRIO}

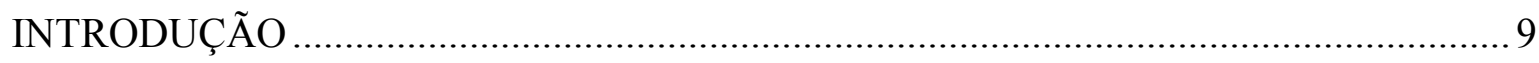

1. A PROTEÇÃO DA CRIANÇA E DO ADOLESCENTE .................................................. 13

1.1. Evolução do conceito de família e da relação entre seus membros ............................ 13

1.2. A proteção integral da criança e do adolescente....................................................... 19

1.3. O cuidado como pressuposto do atendimento do melhor interesse do menor ..........26

1.4. A positivação do cuidado e da proteção integral do melhor interesse da criança e do adolescente no Ordenamento jurídico brasileiro ............................................................. 28

1.5. O Ministério Público como ente garantidor dos direitos dos menores ...................... 31

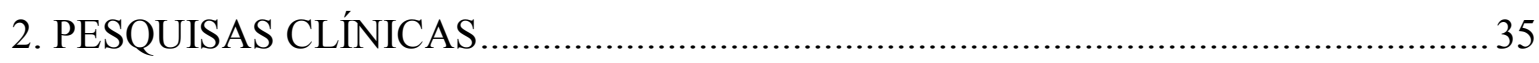

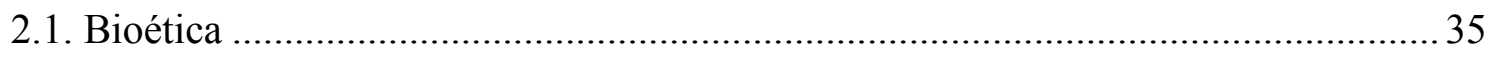

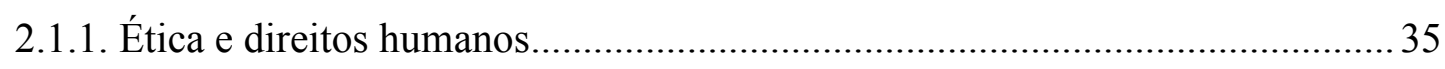

2.1.1.1. Ética: evolução do conceito e fundamento ………………………………..... 35

2.1.1.2. Dignidade da pessoa humana: conteúdo e limites ...................................... 47

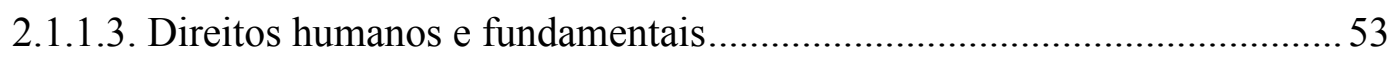

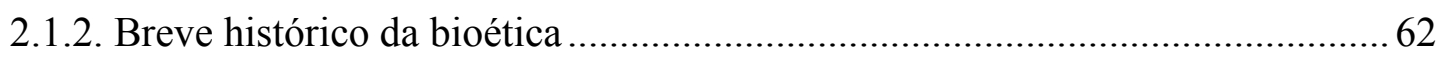

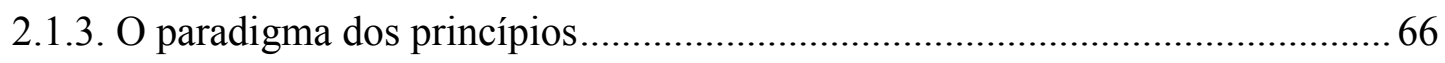

2.1.4. O papel do Direito na regulamentação bioética: a necessidade de normatização

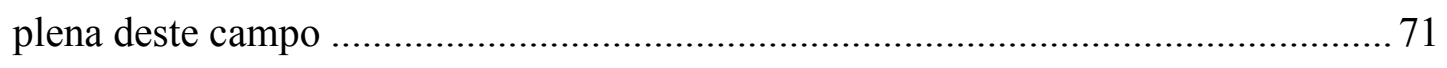

2.2. Pesquisas clínicas com crianças e adolescentes ...................................................... 75

2.2.1 Considerações sobre as experimentações clínicas em geral................................ 75

2.2.2. As fases dos testes com seres humanos de novos produtos médicos e

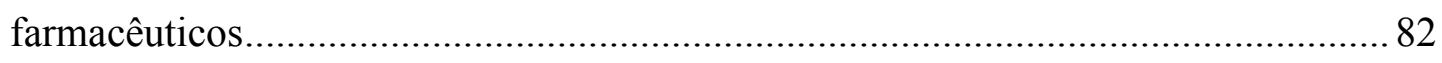

2.2.3. O consentimento livre e esclarecido como requisito básico para a realização de

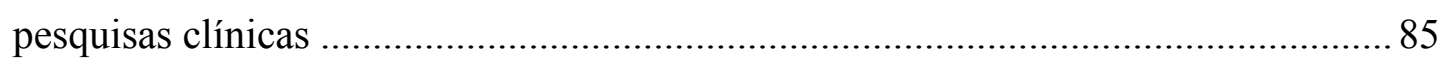

2.2.4. Os experimentos com crianças e adolescentes: considerações gerais ...............91

2.2.5. Requisitos iniciais para a participação de menores em testes clínicos..............93

2.2.6. A necessidade de intervenção do Ministério Público como agente fiscalizador das pesquisas clínicas com crianças e adolescentes .................................................... 99

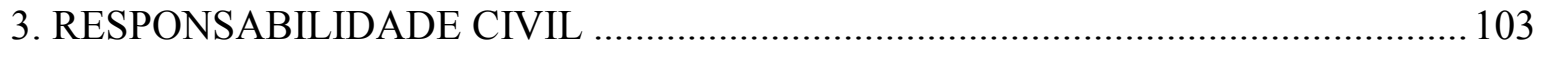

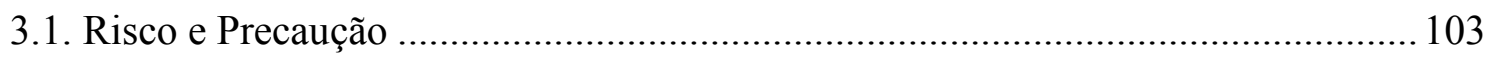


3.1.1. Reflexões sobre o conceito de risco

3.1.2. O processo decisório acerca da assunção dos riscos

3.1.3. O princípio da precaução: definição e diferenças com o princípio da prevenção

3.1.4. A aplicação do princípio da precaução no processo decisório sobre a assunção de riscos 118

3.2. A responsabilidade civil quanto aos danos materiais e morais sofridos por crianças e adolescentes sujeitos de pesquisa clínica 123

3.2.1. Da responsabilidade civil nas atividades médicas 123

3.2.1.1. Considerações gerais 123

3.2.1.2. Da natureza das relações entre pesquisadores e pacientes. 126

3.2.1.3. As obrigações médicas de meio 128

3.2.1.4. As obrigações médicas de resultado 134

3.2.1.5. A responsabilidade civil nas práticas médicas em geral 137

3.2.1.6. Responsabilidade civil de pesquisadores e patrocinadores por danos ocorridos em sede de pesquisas clínicas com crianças e adolescentes.

3.2.2. A responsabilidade civil dos pais e tutores 148

3.2.2.1. Obrigação de indenizar os filhos ou tutelados por danos ocorridos em pesquisas clínicas .......................................................................................... 148

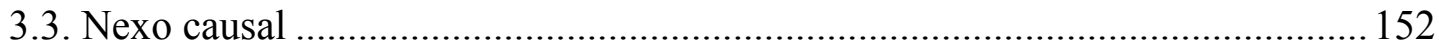

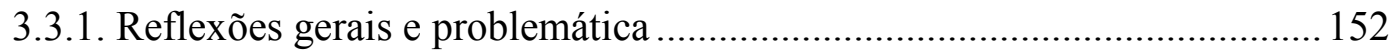

3.3.2. Teoria da perda de uma chance................................................................ 154

3.3.3. Teoria da responsabilidade civil pelo incremento dos riscos..................... 158

3.4. Suspensão e perda do poder familiar.............................................................. 161

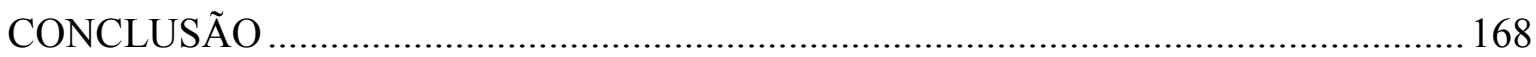

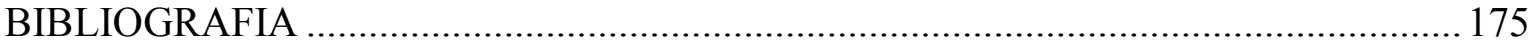




\section{INTRODUÇÃO}

Atualmente, há uma demanda cada vez maior por novos produtos médicos e farmacêuticos, como resultado da incessante busca pela melhora e o prolongamento da vida humana, o que acaba gerando a necessidade de realização de inúmeros experimentos científicos nesta área.

Observe-se que o mercado farmacêutico brasileiro de varejo, segundo a "IMS Health", companhia global que presta serviços de informação, consultoria e tecnologia para as indústrias do setor da saúde, movimentou, no ano de 2011, aproximadamente, R\$ 38 bilhões, o que representa um crescimento de $19 \%$ em relação ao ano anterior, com projeções de contínua expansão até 2017 , quando deverá atingir a marca de R\$ 87 bilhões ${ }^{1}$.

Nesse contexto, a pesquisa clínica, como fase de um estudo que envolve a aplicação experimental de uma nova substância em seres humanos, possui grande importância, já que permite a aferição concreta dos riscos e benefícios desta, para que a sua comercialização se dê do modo mais eficiente e seguro possíveis.

E este cenário não é diferente no que tange aos produtos destinados às crianças e adolescentes. Em muitos casos, a avaliação clínica de uma substância destinada a este público não poderá ser realizada, de modo correto, em adultos, o que acarreta a necessidade de que os menores sejam alçados à categoria de sujeitos passivos de pesquisas.

Ainda, de acordo com a ANVISA, entre 2003 e março de 2006 foram aprovados 564 estudos, sendo $64 \%$ patrocinados diretamente pela indústria farmacêutica ${ }^{2}$. Estas informações, aliás, acabam refletindo a tendência mundial nesta área.

Pela análise dos dados constantes dos parágrafos anteriores, é nítido o interesse que permeia a maior parte das pesquisas clínicas, qual seja o lucro, o que é legítimo, importante frisar, dentro de um sistema capitalista, sem se olvidar, por óbvio, a sua moldura científica.

Percebe-se, desse modo, uma nítida tensão entre o interesse econômico da poderosa indústria da saúde, a independência do pesquisador e, o mais importante de tudo,

Disponível em http://www.imshealth.com/portal/site/ims/menuitem.d248e29c86589c9c30e81 c033208c22a/?vgnextoid=5 f0ceb6973858310VgnVCM10000076192ca2RCRD. Acessado em 03.08.2012.

2 MENEGUIM, Silmara. Avaliação de como os sujeitos da pesquisa entendem sua participação em ensaios clínicos num hospital terciário. Tese(Doutorado pela Faculdade de Medicina da Universidade de São Paulo). São Paulo, 2009. 189p. p. 5. 
a autonomia dos sujeitos de pesquisa, bem como a proteção da sua incolumidade física e psíquica, tendo em vista a sua exposição, nestes experimentos, a riscos não totalmente mensurados.

Em um modo geral, a pesquisa clínica no Brasil é regida pela Resolução 196/96. No tocante às crianças e adolescentes, esta se mostra insuficiente, tanto em seu aspecto formal, na medida em que a matéria deveria ser regulada por instrumento normativo com força de Lei, como no aspecto material, pois não traz uma minuciosa regulação desta área.

A ausência de regramento detalhado se dá, principalmente, no que tange ao controle da atividade de pesquisa com menores e das condutas de precaução cabíveis no sentido de se evitar a ocorrência de danos, inclusive acompanhamento pós-estudo de longo prazo; não previsão da participação do Ministério Público, órgão que possui a atribuição precípua de zelar pelos interesses relativos à infância e à juventude; não disposição específica sobre a responsabilidade civil dos pesquisadores, patrocinadores e, principalmente, dos pais, quanto aos prejuízos eventualmente verificados.

Desse modo, em razão da importância e singularidade do tema tratado, observarse-á, no presente trabalho, a premente necessidade de que sejam estabelecidas regras que protejam a criança e o adolescente, ao mesmo tempo em que permita o avanço tecnológico na área médico-farmacêutica.

Primeiramente, será efetuada uma análise da posição jurídica dos menores, de como se dá a proteção conferida pelo ordenamento, procurando, a partir deste ponto, especificar tal análise no sentido da realização de pesquisas médicas com tais indivíduos. Bastante relevo no trato desta questão assume o principio da proteção do melhor interesse da criança e do adolescente. Enfoca-se, além disso, o perfil institucional do Ministério Público e sua importância na preservação dos direitos das crianças e adolescentes.

Sem dúvida, a bioética, e mais especificamente, as pesquisas clínicas, por lidarem com interesses existenciais das pessoas, como sua saúde e autonomia, estão ligadas aos denominados direitos humanos ou fundamentais, que visam a resguardar, exatamente, aquela esfera mínima intangível de prerrogativas individuais, de que são titulares todos os seres humanos.

Mostra-se imprescindível, pois, a construção de algumas reflexões sobre estes direitos humanos ou fundamentais, a sua qualificação na ordem jurídica, o modo de sua atuação concreta, e sua especificação no âmbito privado através dos chamados direitos da personalidade, a base moral e jurídica que lhes dão sustentação, e em que medida 
influenciam a normatização dos assuntos bioéticos, especialmente os atinentes aos experimentos com seres humanos. Ressalte-se que possuirá papel central neste tema a análise da autonomia individual, que ocasionará profundos reflexos na posterior tarefa de avaliação do chamado consentimento informado e da medida em que a decisão da criança e do adolescente deve influenciar a concretização de sua participação em experimentos clínicos.

Estabelecidas essas premissas, para que se cumpra uma das finalidades propostas, que é a de servir como ponto de reflexão sobre a adequação do ordenamento jurídico e, mais especificamente, do Direito Civil como efetivo instrumento de regulamentação social e proteção da pessoa humana na área dos experimentos, mostra-se necessário efetuar uma investigação histórica acerca da evolução da bioética e da disciplina da pesquisa clínica, de sua importância e das preocupações que rondaram o seu desenvolvimento nas diferentes épocas, bem como o seu estágio atual.

Efetuada tal investigação, importante abordar a noção de riscos, bem como o seu controle, já que estes, como será visto, são inerentes aos procedimentos de pesquisa clínica. Avaliar-se-á em que medida devem ser efetuadas as decisões acerca da assunção ou não de riscos nesta atividade, e como se deve dar a aplicação do princípio da precaução neste processo, na medida em que os interesses das crianças e adolescentes, por sua peculiar condição de seres em desenvolvimento, demanda condutas antecipatórias em relação aos possíveis danos.

Nesse contexto, será extremamente necessário identificar os possíveis problemas e conflitos que possam surgir em relação ao tema proposto, efetuando uma rigorosa análise sobre a sua profundidade e eventuais soluções que possam ser apresentadas pelo próprio ordenamento jurídico ou mesmo pela teoria geral do Direito, tanto com bases preventivas, quanto "a posteriori”, nos casos em que surja um conflito.

E, finalmente, com a exata compreensão dos conceitos supramencionados, avaliar-se-á de que modo deve ser realizada a regulamentação desta área, tanto em termos preventivos, propugnando-se a intervenção do Ministério Público, como em termos reparadores, verificando-se quais os requisitos necessários à responsabilização civil de pesquisadores, patrocinadores, pais e responsáveis legais, especialmente tutores, inclusive no tocante ao exercício do poder familiar, nos casos em que tais pesquisas médicas realizadas com menores causem danos à sua saúde.

Portanto, o trabalho ora proposto almeja, ciente de suas limitações, contribuir para 
uma reflexão acerca dos atuais temas citados. Tal tarefa é imprescindível para que se busque a recolocação do Direito como efetivo instrumento regulatório da boa convivência em âmbito tão sensível como o das pesquisas clínicas com crianças e adolescentes. Desejase, além disso, oferecer críticas e sugestões que possuam como escopo o estabelecimento de parâmetros relativamente seguros, aptos a servirem como ponto de partida para uma modificação legislativa, bem como parâmetro ao aplicador do Direito diante do caso concreto. 


\section{A PROTEÇÃO DA CRIANÇA E DO ADOLESCENTE}

\subsection{Evolução do conceito de família e da relação entre seus membros}

A família como ambiente primeiro dos relacionamentos humanos interpessoais teve inúmeras variações estruturais de acordo com cada época e sociedade específicas. Difícil é identificar uma marcha clara e única de desenvolvimento desta instituição que, sem dúvida, foi primordial para a vida do homem em sociedade ${ }^{3}$.

Aliás, importante frisar, que "o grupo familiar sempre caminhou junto aos interesses econômicos, o que também contribuiu decisivamente para determinar os contornos e as finalidades das relações familiares"4. Todavia, em alguns momentos e no tocante a determinados aspectos, é possível identificar o tipo de relação existente entre os componentes da família e sua posição frente aos demais grupos da sociedade e mesmo ao Estado.

Pela influência histórica que nos foi legada de maneira marcante ${ }^{5}$, cumpre denotar a concepção da família, de acordo com as tradições romana e cristã, e as posteriores transformações históricas que sobre esses modelos foram operadas ${ }^{6}$.

Neste contexto, em um primeiro momento, especialmente em Roma, enxerga-se a família como uma ligação natural, mas nem sempre, entre várias pessoas, sob a chefia de um líder masculino, que possui, pois, poder sobre os demais membros. Há preponderância da ligação biológica entre os indivíduos, com acentuada prevalência da figura paterna, e a consideração dos demais membros como espécie de propriedade do chefe ${ }^{7}$.

A concepção cristã de família, construída no período medieval, partindo daquela

3 "Esse grupo teve muitas variações nas formas e configurações nos mais diversos pontos geográficos, nas mais diferentes épocas e nas mais diferentes culturas". COSTA, Maria Isabel Pereira da. "A responsabilidade civil dos pais pela omissão do afeto na formação da personalidade dos filhos". In: Revista Jurídica, ano 56, $\mathrm{n}^{\mathrm{o}}$ 368, junho de 2008. Porto Alegre, 2008. p. 47. No mesmo sentido, cf. GONÇALVES, Vitor Fernandes. "Da proteção da pessoa dos filhos no Brasil e na Inglaterra". In: Revista da Fundação Escola Superior do Ministério Publico do Distrito Federal e Territórios. v.2, n.94, jul./dez. 1994. Brasília, 1994.. pp. 199-216. pp. 202-204.

4 COSTA, Maria Isabel Pereira da. ob. cit. p. 50.

5 Devemos ressalvar, contudo, que tal influência não é a única, sendo o conceito de família no Direito e na sociedade brasileira fruto de amplo contato com outras culturas e mesmo com a construção dada a essa instituição por outros Estados.

6 Porém, mesmo entre tais tradições existem algumas variações acerca do que seja a família e como se deve dar a relação entre seus membros, o que não se mostra crucial ser analisado no presente trabalho.

7 RUSSO, José. “As sociedades afetivas e sua evolução”. In: Revista Brasileira de Direito de Família. Ano VII, no 32, out./nov. 2005, Porto Alegre: IOB Thomson, 2005. pp. 40-49. p. 41. 
legada pelos romanos, tem como fonte o casamento, restringindo o próprio tamanho do organismo, passando a mulher a ter uma importância, ainda que limitada, na organização da vida doméstica e na criação dos filhos ${ }^{8}$. Entretanto, a mulher e os filhos ainda estavam sob a égide da autoridade masculina, o que irá se modificar, principalmente, com a Revolução Industrial e o liberalismo, até por uma questão de utilidade, de liberação de mão-de-obra para o mercado de trabalho, redundando em uma visão mais igualitária entre os membros da família.

Observe que a concepção de família no Direito brasileiro espelha bem o estágio da sociedade de cada época. No império, e mesmo nos primeiros anos da República, em um país essencialmente agrário, o poder familiar, ou pátrio poder, era exercido preponderantemente pelo pai, somente sendo exercido pela mãe em caso de ausência ou incapacidade daquele ${ }^{9}$.

De fato, o artigo 380 do Código Civil de 1916 revelava a opção extremamente patriarcal e trazia em seu bojo a adoção de um conceito de família baseado "na hierarquização das funções, na desigualdade de direitos entre marido e mulher, na discriminação dos filhos, na desconsideração das entidades familiares não fundadas no casamento e no predomínio dos interesses patrimoniais em detrimento do aspecto afetivo" $"$.

Sem prejuízo desta constatação, há que se ressaltar, todavia, que já se começava a entender necessária a participação da mulher nas questões atinentes aos rumos da família, com o afastamento de uma concepção que enxergava na sociedade conjugal uma ditadura do marido em face da esposa.

O próprio artigo 240 do Código Civil de 1916, aliado a uma concepção católica da família que impunha uma especial consideração do marido com a esposa, justificava a adoção deste posicionamento que alçava a mulher casada à condição de auxiliar do homem nas situações domésticas. A desigualdade e a arbitrariedade nas relações conjugais,

\footnotetext{
Idem. p. 43.

9 "Da República, anota-se o Dec. 181, de 24.01.1890, que veio conceder à viúva o direito de exercer o pátrio poder, desde que não convolasse novas núpcias. Regra de significativa importância e que consistiu num marco da evolução do pátrio poder, por deixar de considerá-lo como prerrogativa exclusivamente masculina, ainda que o jugo do homem somente viesse a ser definitivamente superado quase cem anos depois”. COMEL, Denise Damo. Do poder familiar. São Paulo: Editora Revista dos Tribunais, 2003. p. 25.

10 SILVA, Cláudia Maria da. "Indenização ao filho". In: Revista Brasileira de Direito de Família, v. 6, n 25, ago./set. 2004. Porto Alegre: Síntese, IBDFAM, 2004. pp. 122-147. p. 129.
} 
portanto, não eram totalmente aceitas na sociedade, posição esta que iria ganhar força nos anos seguintes ${ }^{11}$, no sentido do estabelecimento da plena paridade decisória sobre os rumos familiares entre homens e mulheres.

Com o passar dos anos houve um abrandamento do poder legal único do pai, e mesmo da consideração dos filhos como meros objetos postos à disposição deste, o que levou a mulher a ganhar cada vez mais importância no ambiente familiar, refletindo a crescente inserção dela como efetivo ator social e a busca incessante pela igualdade com os homens. Além disso, desenrolou-se o nascimento do sistema protetivo das crianças e adolescentes, progressivamente ampliado ${ }^{12}$.

O citado artigo 380 do Código Civil de 1916 foi posteriormente modificado, preceituando que o pátrio poder seria exercido por ambos os pais, de maneira conjunta ${ }^{13}$. Durante anos, a legislação civil foi paulatinamente alterada no sentido de alargar o conceito de família e regular de maneira mais democrática a relação entre os seus sujeitos.

Pouco citada por sua construção autoritária, a Constituição de 1937 consubstancia a primeira normatização com vistas a garantir a proteção da integridade das crianças e jovens $^{14}$, através do quanto contido em seu artigo 127.

Quanto às disposições constitucionais, pouca coisa fora modificada até a entrada em vigor da Carta Magna de 1988, cuja disciplina foi complementada, posteriormente, pelo Estatuto da Criança e do Adolescente (Lei 8.069/1990). Essa Constituição trouxe ao

11 COMEL, Denise Damo. ob. cit. p. 27-28.

12 "Esse modelo da família começou a se alterar com o ingresso da mulher no mercado de trabalho e, ao mesmo tempo, com o desaparecimento da função dos pais de educar os filhos, decorrente da evolução das ciências e das técnicas, bem como da falta de tempo dos pais abarrotados de serviço em seus postos de trabalho". GONÇALVES, Vitor Fernandes. ob. cit. p. 201.

13 "Conquistou a mulher, assim, o direito subjetivo inerente ao pátrio poder. Entretanto, pelo fato de se ter atribuído o exercício ao pai com a colaboração dela, manteve-se de certa forma, o sistema anterior de chefia da casa pelo marido, auxiliado pelo mulher. Com relação aos filhos, ao menos no texto da lei, o pai continuava no primeiro plano e a mulher, no de coadjuvante". COMEL, Denise Damo. ob. cit. p. 34. Mas não deixamos de reconhecer que esta tímida conquista preparou terreno para os avanços em igualdade entre os cônjuges posteriormente introduzidos nas relações familiares.

14 "No que se refere ao tema proposto neste trabalho, este texto constitucional trouxe, pela primeira vez, o dever paterno de conferir tratamento igual entre os filhos naturais e os legítimos e, ainda previu, que deveriam ser objeto de cuidados e garantias especiais à infância e à adolescência, assegurando às crianças e aos adolescentes uma vida digna. Cuidou de, pioneiramente, dispor sobre a responsabilização dos pais pelo abandono dos filhos: Art 127 - A infância e a juventude devem ser objeto de cuidados e garantias especiais por parte do Estado, que tomará todas as medidas destinadas a assegurar-lhes condições físicas e morais de vida sã e de harmonioso desenvolvimento das suas faculdades. $\mathrm{O}$ abandono moral, intelectual ou físico da infância e da juventude importará falta grave dos responsáveis por sua guarda e educação, e cria ao Estado o dever de provê-las do conforto e dos cuidados indispensáveis à preservação física e moral. Aos pais miseráveis assiste o direito de invocar o auxílio e proteção do Estado para a subsistência e educação da sua prole”. SILVA, Cláudia Maria da. ob. cit. p. 125. 
ordenamento jurídico brasileiro a ideia de família em que a relação entre seus integrantes deve realizar-se com foco no afeto e não exclusivamente na patrimonialidade e na sujeição dos filhos ao poder dos pais ${ }^{15}$.

De todo modo, pode-se dizer que a atual Constituição Federal estabeleceu a necessidade de proteção integral dos direitos da criança e do adolescente no seio familiar e a busca pelo atendimento de seu melhor interesse. A Autoridade parental ${ }^{16}$ passa a ser responsável com o reconhecimento de direitos especiais aos filhos, calcados na condição de pessoa em desenvolvimento, e da democratização no ambiente familiar:

[a] partir dessa valorização dos membros da família e da importância dos interesses individuais desses sujeitos, a preocupação com a formação e o desenvolvimento da personalidade tornou-se imperiosa e mais evidente. Neste contexto, a filiação - notadamente quando se trata de menores ganha especial atenção, uma vez que se trata de seres com personalidade em formação, pelo que se faz ainda mais imperiosa a convivência familiar plena ${ }^{17}$.

Inegável que a dependência, tanto econômica quanto moral e intelectual, dos filhos, em seus primeiros anos de vida em relação aos seus pais, acaba por conduzir a uma visão destes como seres subordinados no seio familiar ${ }^{18}$.

15 "No Brasil e na Inglaterra, como de resto em todo o mundo, o Direito do Menor muito se desenvolveu, desde a aprovação pela Organização das Nações Unidas da Declaração dos Direitos da Criança, em 20 de fevereiro de 1959. A adoção, contudo, da Convenção das Nações Unidas sobre os Direitos da Criança, em 20.11.89, em a qual os países partes se comprometiam a adotar em seus ordenamentos internos um regime jurídico de proteção integral ao menor, está sendo decisiva na reformulação mundial de tal legislação. Caminha-se a passos largos para a unificação das regras de proteção à criança entre as nações civilizadas. Tanto o Brasil como a Inglaterra, signatários da acima citada convenção, reformularam por completo suas legislações: o Brasil com o Estatuto da Criança e do Adolescente (ECA), e a Inglaterra, com a Children act of 1989. Ambos adotam um regime jurídico de proteção integral à criança muito parecido". GONÇALVES, Vitor Fernando. ob. cit. p. 215.

16 "De fato, na hipótese examinada não havia como conciliar a regra constitucional com a do Código Civil de 1916, posto que a discriminação da mulher era evidente na norma civil, o que a tornava incompatível com aquela. Forçoso, portanto, era reconhecer que não foi recepcionada pela nova ordem jurídica. A rigor, então, se estava diante de uma lacuna da lei, uma vez que não havia legislação civil dispondo a respeito de como deveria ser exercido o pátrio poder em igualdade de condições pelo homem e pela mulher. E uma vez admitida a existência de lacuna, enquanto não vencida pelo Poder Legislativo, o suprimento deveria ser feito na forma do que dispõe o art. $4^{\circ}$ da LICC, ou seja, no caso concreto, mediante a analogia, os costumes e os princípios gerais de direito". COMEL, Denise Damo. ob. cit. p. 45. Apenas deve ser ressalvado que a Lei de Introdução ao Código Civil (Decreto-Lei 4567, de 1942), LICC, por força da alteração carreada pela Lei $\mathrm{n}^{\circ} 12.376$, de 2010, passou a ser denominada Lei de Introdução às normas do Direito Brasileiro.

17 SILVA, Cláudia Maria da. ob. cit. p. 131.

18 "O que a história mostra, e as histórias do pensamento e das instituições mostram junto, é que, se a relação entre homens e mulheres, em família, foi sempre baseada em uma concepção naturalista de 
Por conta dessa realidade, no passado, os filhos eram vistos de forma primariamente utilitarista, guiados e subordinados pelos pais, de maneira arbitrária, no sentido do atendimento dos próprios interesses destes, sem qualquer justificativa das próprias razões. Até tempos recentes, a ideia de poder, ainda que atenuada pela concepção de responsabilidade, era a vigente para a caracterização da relação de filiação, ou seja, o exercício potestativo de um direito dos pais sobre os filhos, algo resumido muito bem na expressão "pátrio poder", utilizada no Código Civil de $1916^{19}$.

Observa-se que tal visão perde sentido nos tempos atuais, na medida em que se consolida a ideia do menor como pessoa dotada de características peculiares que demandam o reconhecimento de direitos especiais, e a construção, de modo saudável, da personalidade destes indivíduos torna-se o principal objetivo da família.

Ora, a criança ou o adolescente, apesar da condição de dependência, é dotada de um certo grau de autonomia, sendo imprescindível a concessão de uma esfera de liberdade nos campos em que, de acordo com o seu estágio de desenvolvimento, possa decidir sozinha. Desconsiderar tais atributos dos menores, cerceando de maneira injustificável sua autonomia, concretiza efetivo desprezo ético ${ }^{20} \cdots$, não tolerável em uma sociedade democrática.

Tem-se, com base na concepção apresentada, uma situação diferenciada em que se busca enfocar a família não como mero conjunto de liames entre pessoas sujeitas a relações de poder impostas e, sim, como feixe de deveres, direitos e obrigações recíprocos, cuja finalidade é contribuir ao desenvolvimento das crianças e adolescentes como pessoas cada vez mais autônomas, o que se faz garantindo-se a formação saudável e íntegra delas, nos aspectos psíquico e físico ${ }^{21}$.

dependência e subordinação da mulher, com muito mais razão será apontada uma dependência e subordinação dos filhos em relação aos pais". HIRONAKA, Giselda Maria Fernandes Novaes. "Responsabilidade civil na relação paterno-filial". In: Novos Estudos Jurídicos, v.7. n.14. pp. 69-101. Abr. 2002, Itajaí, 2002. p. 79.

19 Para uma análise mais completa desta evolução, Cf. HIRONAKA, Giselda Maria Fernandes Novaes. $o b$. cit. pp. 70-86.

20 Idem. p. 87.

21 "Segundo a psicologia, o poder parental pode ser expresso por uma fórmula extremamente resumida, segundo a qual o bom pai (ou mãe) é aquele capaz de desempenhar papéis, desenvolver funções e ocupar lugares na rede de relações familiares, promovendo assim o desenvolvimento e o cuidado efetivo com seu filho. Assim, desempenhar um papel implica ocupar o lugar imaginário destinado pelo desenvolvimento cultural, ao homem/mulher. Apontar como, dentro de determinada cultura, os diferentes sexos se comportam, se desenvolvem, enfim, como vivem. Por seu turno, desenvolver funções significa cuidar, prover, e zelar pelo desenvolvimento biopsicossocial e emocional da prole, promovendo os cuidados de 
Essa preocupação primordial com o melhor interesse da criança depende da criação e contínua manutenção do afeto entre pais e filhos ${ }^{22}$. Esta relação baseada no afeto se mostra muito mais eficaz e adequada para a tarefa de desenvolvimento saudável dos menores, do que aquela baseada no poder, no medo, na arbitrariedade. A autoridade dos pais deve sempre ser dirigida ao atendimento daqueles objetivos acima tratados, sendo palavra de ordem a construção permanente da liberdade das crianças e adolescentes até atingirem a fase adulta, o que demanda o perene exercício do diálogo familiar.

Veja-se, inclusive, que a exemplo do quanto é utilizado nas legislações francesa, alemã e britânica, pugna-se pela melhor adequação das expressões "autoridade", "cuidado" ou "responsabilidade parental", respectivamente, em relação àquela utilizada pelo Código Civil brasileiro, qual seja "poder familiar"23.

É evidente que há uma hierarquia dos pais sobre os filhos, até por questões de experiência, de maior preparo, de possibilidades mais acertadas de orientação, mas cujo exercício é condicionado à proteção integral do melhor interesse da criança.

A família, nesse contexto, passa a ter uma finalidade constitucional de formação da criança e do adolescente e de proteção dos interesses deles. Ou seja, "[a] principal função da família é, sem dúvida, a de criar as condições para o desenvolvimento da personalidade dos filhos para que se tornem dignos integrantes da sociedade, sabendo

sobrevivência, saúde, educação, desenvolvimento cultural, intelectual e esportivo, além de subjetivá-lo, ou seja, transformar um ser, a princípio regido por respostas instintivas, em um ser com características únicas e diferenciadas que promovem sua individualidade e dignidade". MONACO, Gustavo Ferraz de Campos; CAMPOS, Maria Luiza Ferraz. "O Direito de audição de crianças e jovens em processo de regulação do exercício do poder familiar”. In: CANEZIN, Claudete Carvalho (coord.). Arte Jurídica Biblioteca Científica de Direito Civil e Processo Civil.. v. 3, nº1, Curitiba: Juruá, 2006. pp. 93-105. p. 94

22 "Conceber as famílias como associações determinadas pelo afeto significa necessariamente recusar que sejam determinadas por uma relação de dominação ou poder. Paralelamente, significa dar a devida atenção à necessidades manifestas pelos filhos em termos, justamente, de afeto e proteção. Poder-se-ia dizer, assim, que uma vida familiar na qual os laços afetivos são atados por sentimentos positivos, de alegria e amor recíprocos em vez de tristeza ou ódio recíprocos, é uma vida coletiva em que se estabelece não só a autoridade parental e a orientação filial, como especialmente a liberdade paterno-filial. Uma vida familiar que, ao contrário, é marcada pelas relações de ódio é claramente uma vida na qual se perdeu qualquer equilíbrio afetivo, porque já não se percebem, aí, identidades, semelhanças, generosidades. Pior: concebe-se que alguma paz só pode ser conquistada se se impuser, de qualquer das partes, uma tirania da opressão sobre a parte inimiga. Aí já não se trata mais de responsabilidade numa relação paterno-filial, mas de uma responsabilidade mais apropriada àquilo que Grotius chamava de direito de guerra". HIRONAKA, Giselda Maria Fernandes Novaes. ob. cit. p. 99.

23 FACHIN, Luiz Edson. "Do pater familias à autoridade parental. Elementos da travessia entre 'pátrio poder', 'poder familiar' e 'autoridade parental'". In: Revista do Advogado. Ano XXXI, nº 112, jul. 2011. São Paulo: AASP, 2011. pp. 99-103. pp. 100-101. 
também respeitar a dignidade de todos" 24 .

A transformação procedida pela Constituição acabou se refletindo, ainda que parcialmente $^{25}$, no Código Civil de 2002, que traz em seu bojo algumas inovações importantes no trato do Direito de Família, especialmente no que concerne ao reconhecimento do caráter instrumental e afetivo da entidade familiar (e não dos filhos), destinada a garantir o bem estar e segurança de todos seus membros, bem como o desenvolvimento e educação dos menores de idade.

Dessa maneira, de acordo com tal estágio de normatização é que surge a importância de se compreender as noções de proteção integral, de atendimento do melhor interesse da criança e do cuidado, que permitirão a tomada das atitudes corretas que visem a efetivar o comando constitucional.

\subsection{A proteção integral da criança e do adolescente}

Interessante ressaltar que a Constituição Federal, os documentos internacionais sobre proteção dos direitos da criança e do adolescente, bem como o Estatuto da Criança e do Adolescente concebem o princípio da cooperação, que pode ser entendido como um dever imposto à família, à sociedade ${ }^{26}$ e ao Estado de proteção dos interesses dos menores, sobremaneira do direito à vida e ao desenvolvimento saudável ${ }^{27}$. Há uma atribuição concorrente entre esses entes, sendo todos responsáveis concomitantemente e em caráter não exclusivo ${ }^{28}$ pela consecução do objetivo anteriormente delineado.

24 COSTA, Maria Isabel Pereira da. ob. cit. p. 57.

25 COMEL, Denise Damo. ob. cit. pp. 52-53.

26 Exemplo claro dessa necessária participação da sociedade na proteção dos direitos da criança e do adolescente são os Conselhos Tutelares, órgãos não jurisdicionais, autônomos e permanentes, cuja estruturação e atribuições estão previstas nos artigos 131 e ss. do Estatuto da Criança e do Adolescente. Haverá ao menos um destes conselhos em cada município, e seus membros são eleitos pela sociedade.

27 "Do nascimento à fase adulta, os filhos crescem e se desenvolvem em torno da auto estima, do senso de moralidade, responsabilidade, empatia e de outros tantos aspectos ligados à formação da personalidade. É por isso que a cautela em torno da convivência familiar nasce com o indivíduo, uma vez que são determinantes para sua personalidade a forma e o contexto familiar quando de seu ingresso à vida. A criança precisa e depende de seu criador. Se ela é negligenciada, maltratada, rejeitada e abandonada, não desenvolve suas capacidades básicas e sofre prejuízos em sua personalidade”. SILVA, Cláudia Maria da. ob. cit. p. 132.

28 "Não apenas a família é responsável, com a atribuição inicial dos valores fundamentais a respeito do bem agir no meio comunitário. Temos a obrigação concorrente por parte do Estado, na condição de ente com poder superior, que atuará sempre que houver necessidade, e da sociedade, na qualidade de agente cooperativo, e todos com o objetivo comum de propiciar aos infantes e jovens um ambiente sadio e livre de riscos. Destaca-se a importância do conceito a delinear o trinômio família-sociedade-Estado como 
A atribuição cooperativa ${ }^{29}$ deve ser destinada à proteção integral da criança e do adolescente, cuja ideia principal é trazida pelos diplomas normativos acima referidos. Tal concepção representa uma mudança total de rumo em relação ao que era acolhido no antigo Código de Menores, qual seja a teoria do direito tutelar, centrada na questão penal de condutas levadas a cabo pelo menor ou contra $\mathrm{si}^{30}$.

Aos direitos da personalidade das crianças e adolescentes são destinadas medidas especiais de defesa e fomento, com vistas a garantir o melhor desenvolvimento deles:

[c]ompreendem-se, em se tratando de proteção integral, todas as iniciativas por parte da família, da sociedade e do próprio Estado (no enfoque já abordado do que vem a ser o princípio da cooperação) no sentido de garantir à criança e ao adolescente um ambiente propício a seu regular e peculiar desenvolvimento. O paradigma da proteção integral dos infantes e jovens é estabelecido numa tomada de atitudes positivas, amplas e irrestritas por todos os envolvidos nesse processo ligado intimamente à vida das crianças e dos adolescentes, de modo que não se excluam quaisquer gestos a assegurar seus direitos fundamentais. Tanto essa noção de proteção integral engloba toda e qualquer iniciativa favorável aos infantes e jovens que o próprio artigo $3^{\circ}$ da Lei $n^{\circ} 8069 / 90$ diz que eles 'gozam de todos os direitos fundamentais inerentes à pessoa humana, sem prejuizo da proteção integral de que trata esta lei ${ }^{31}$.

decisivo para a implementação e respeito aos direitos da criança e do adolescente, não havendo a exclusão de um deles quando da atuação do outro. Aí reside o ponto fulcral do princípio da cooperação estabelecido pelo artigo 18 do Estatuto da Criança e do Adolescente. Poderá haver a soma de esforços entre os agentes para a consecução da finalidade de alcance de uma qualidade de vida satisfatória para crianças e adolescentes, Nunca se conceberá a exclusão. Nesse labor, há a colaboração de todos. Se do ponto de vista filosófico é imaginada a construção de uma mentalidade solidária em prol da infância e da juventude, protegendo-se crianças e adolescentes pelas suas próprias peculiaridades de vida incipiente, sob a ótica do Direito vemos plena responsabilidade dos três atores no plano de atendimento das necessidades infanto-juvenis". LAMENZA, Francismar. Os direitos fundamentais da criança e do adolescente e a discricionariedade do Estado. Tese(Doutorado pela Faculdade de Direito do Largo São Francisco da Universidade de São Paulo). São Paulo, 2006. 205 p. pp. 24-25.

29 "A família é uma instituição integrada - e não separada - na sociedade e no Estado. As instituições sociais e o Estado são susceptíveis de afectarem profundamente a natureza e a forma da família. As políticas do Estado podem atingir o funcionamento da família. Pelo mesmo motivo, a natureza e o funcionamento da família produzem efeitos, também significativos, noutras instituições sociais e no Estado. Esta imagem de simbiose parece mais adequada para descrever o modelo de família em relação com a sociedade e com o Estado do que a metáfora da separação de esferas. A família está situada na sociedade e no Estado família sociedade e Estado interagem. Alterações numa instituição repercutem-se, correspondentemente, na outra". TOMÉ, Maria João Romão Carreiro. "Algumas considerações sobre a dependência". In: CAMPOS, Diogo Leite de; CHINELlATO, Silmara Juny de Abreu (coords). Pessoa Humana e Direito. Coimbra: Almedina, 2009. pp. 295-348. pp. 336-337.

30 ELIAS, Telma de Melo. Direito à vida e à saúde no Estatuto da Criança e do Adolescente. Dissertação(Mestrado pela Faculdade de Direito do Largo São Francisco da Universidade de São Paulo). São Paulo, 2005. 142p. p. 23.

31 LAMENZA, Francismar. ob. cit. pp. 31-32 (grifo do autor). 
Baseado em tal premissa e associando-a ao princípio da cooperação, pode-se vislumbrar que a proteção integral da criança além de ser levada a cabo pela atuação familiar e por medidas de política pública emanadas do Poder Executivo, também depende do estabelecimento de legislação que busque a realização máxima desta proteção, e da atuação de órgãos de físcalização do cumprimento das medidas voltadas ao atendimento de tal função, como o Ministério Público e o Poder Judiciário.

Observa-se que essa preocupação está intimamente ligada à especial situação em que se encontram as crianças e adolescentes, de início da vida, da formação física, psíquica, intelectual e moral, em que qualquer dano produzido nesse desenvolvimento terá efeitos indeléveis para toda a sua existência ${ }^{32}$. Crianças e adolescentes são mais sensíveis, pois, a qualquer alteração no regular e esperado processo de amadurecimento e aprendizado, e demandam uma proteção cuidadosa de seus interesses, em todos os níveis.

Tanto a Declaração Universal dos Direitos da Criança, quanto a Convenção sobre os Direitos da Criança, incorporada na ordem jurídica interna mediante o Decreto Legislativo $\mathrm{n}^{\mathrm{o}} 28$, de 14 de setembro de 1990, promulgado pelo Decreto Presidencial $\mathrm{n}^{\circ}$ 99.710, de 21 de novembro de 1990, ressaltam, em seus preâmbulos, o referido peculiar estado de pessoa em desenvolvimento assumido pela criança e pelo adolescente, determinando uma atenção especial por parte da família, do Estado e da sociedade ${ }^{33}$.

A preocupação demonstrada nos dispositivos jurídicos acima tratados é exatamente garantir ao menor um ambiente em que possa desenvolver suas potencialidades, moldando-se um cidadão (no sentido lato da palavra) que tenha condições na vida adulta de, verdadeiramente e de modo integral, autodeterminar-se e conviver, de maneira pacífica, na sociedade, contribuindo também para o aprimoramento dela.

Aliás, é dentro dessa perspectiva que o Código Civil regulamenta o exercício do agora denominado "poder familiar", a que estão sujeitos os filhos menores não emancipados, ao estabelecer certas prerrogativas aos pais. Estas representam instrumentos

\footnotetext{
32 "Na fase infanto-juvenil da vida humana, há a estruturação da personalidade, com reflexos diretos na psique do ser que irão durar por toda a existência da pessoa. Também é nesse período fugaz que se processa o desenvolvimento físico da criança e do adolescente - e o bem estar depende dessa estrutura que está sendo construída durante o lapso do hiato que se estende por toda a infância e a adolescência. Com o atendimento integral dos direitos das crianças e dos adolescentes, garante-se a passagem para a vida adulta com um mínimo de qualidade de vida, eliminando-se riscos desnecessários para o corpo físico e para a esfera psíquica a envolver essas pessoas em condições diferenciadas de desenvolvimento. Idem. p. 34.

33 ELIAS, Telma de Melo. ob. cit. p. 14.
} 
voltados ao efetivo cumprimento dos deveres de educação, sustento, guarda, companhia, segurança, representação, assistência e provimento de bem estar da prole. Extingue-se este poder, conforme o artigo 1.635, do Código Civil, somente pela morte dos genitores ou do filho, pela emancipação, maioridade, adoção ou decisão judicial de perda.

Percebe-se que o poder familiar deve ser sempre exercido de acordo com o atendimento do melhor interesse da criança e do adolescente e com a proteção integral dos direitos a eles reconhecidos pela ordem jurídica brasileira.

Traduz-se, em realidade, não como um direito subjetivo ${ }^{34}$ dos pais, mas um poderdever $^{35}$, ou função, voltado à garantia do pleno e saudável desenvolvimento dos filhos, da defesa intransigente dos interesses destes perante eventuais prejuízos que possam sofrer ${ }^{36}$, e da construção de um ambiente calcado no afeto e na responsabilidade mútuas. Trata-se de uma relação de via dupla entre pais e filhos, em que direitos e deveres recíprocos servem ao alcance dos objetivos acima mencionados.

O Código Civil de 2002, apesar de reconhecer a mudança de paradigma de uma família patriarcal para uma entidade baseada no amor e na igualdade entre seus membros, o que aliás se impunha em razão da normatização estabelecida pela Constituição Federal, acabou procedendo apenas a modificações localizadas no trato do assunto em relação à disciplina civilista anterior. A regulação dos deveres e direitos que compõem a moldura do poder familiar, bem como das causas de suspensão e extinção desse, manteve-se, em geral, bem próxima daquela enunciada pelo Código de $1916^{37}$.

Importante ressaltar que a titularidade do poder familiar, salvo os casos de suspensão e extinção, pertence ao pai e à mãe, conjuntamente, que possuem comunhão de escopo na preservação do bem-estar da prole, sem prejuízo do exercício da referida função

34 Há certa divergência na doutrina acerca da real natureza jurídica do poder familiar. Para uma análise oportuna acerca das diferentes concepções encontradas, cf. PEREIRA JÚNIOR, Antônio Jorge. "Fundamentos de fiscalização e orientação do poder familiar". In: Revista da Faculdade de Direito da Universidade de São Paulo, vol. 97, jan-dez 2002. São Paulo, 2002. pp. 139-179. pp. 140-146.

35 Comentando o artigo 22, do Estatuto da Criança e do Adolescente, Romero de Oliveira Andrade aduz que “elenca os deveres dos pais para com os filhos menores, quais sejam: sustento, guarda, educação, e a obrigação de cumprir e fazer cumprir as determinações judiciais no interesse da criança e do adolescente. Trata-se de verdadeiro 'dever familiar', consequência do poder familiar, posto que a este corresponde aquele, como se fossem faces de uma mesma e valiosa moeda asseguradora de direitos da criança e do adolescente". In: CURY, Munir (coord.). Estatuto da Criança e do Adolescente Comentado. Comentários jurídicos e sociais. 11 a ed. São Paulo: Malheiros Editores, 2010. pp. 119-120. p. 119.

36 COMEL, Denise Damo. ob. cit. p. 62.

37 LOBO, Paulo Luiz Netto. Do poder familiar. Disponível em .http://www.ibdfam.org.br/?artigos\&artigo=127. Acessado em 30.05.2012. 
poder ocorrer, no plano da eficácia, mediante atuação de apenas um dos genitores ${ }^{38}$.

Assim, o ideal é que a atuação na realidade aconteça através de prévio concerto dos pais, principalmente nas questões mais complexas, que envolvam peculiares e sensíveis interesses dos filhos. Não obstante, nem sempre isso é possível, razão pela qual presume-se, relativamente, o consentimento do outro genitor na prática de determinado ato atinente à prole, quando levado a cabo por apenas um deles, salvo naqueles casos em que se exige a concordância expressa de ambos, como ocorre, por exemplo, com a emancipação ${ }^{39}$, ou que envolvam, como já citado, assunto de especial relevo, como aqueles ligados a direitos da personalidade, ou que possam acarretar consequências sérias ao menor.

Não se pode olvidar, ainda, aqueles casos, previstos pela legislação civil, em que o poder familiar se concentra nas mãos de apenas um dos genitores. É o que ocorre quando somente um dos pais for desconhecido, incapaz, falecido, ou estar, temporariamente ou definitivamente, privado da titularidade daquela função. As situações descritas, contudo, não modificam o modo ideal de exercício do poder familiar, sempre voltado, é importante frisar novamente, ao atendimento, de maneira prioritária, do melhor interesse da criança e do adolescente.

As constatações acerca do papel central exercido pela família no desenvolvimento dos menores não impede a atuação preventiva e repressiva do Estado $^{40}$ no sentido de garantir a proteção integral dos direitos da criança e adolescente, confirmando, aliás, o quanto enunciado no início do presente capítulo acerca da cooperação. A atuação estatal deve se restringir ao estritamente necessário, o que revela a necessidade de total

38 COMEL, Denise Damo. ob. cit. p. 80.

39 Conforme previsto pelo artigo $5^{\circ}$, parágrafo único, inciso I, do Código Civil.

40 "Pode-se imaginar a pessoa envolta por três círculos: mais próximo a ela está família, seguida pela sociedade (nas diversas entidades em que possa se manifestar e na própria sociedade política) e pelo Estado. O desconforto social do círculo mais íntimo faz-se sentir no meio social seguinte, e o desconforto deste, por sua vez, reflete no Estado. No que se refere ao menor de idade, a atuação insuficiente do primeiro círculo - família - exige de imediato a atuação do meio social seguinte. A insuficiência deste meio leva ao Estado. No entanto, ante a disfunção dos círculos sociais mais próximos ao indivíduo, o Estado é a entidade a quem primeiro se cobra uma providência. Nada mais razoável, uma vez que o Estado, entidade artificial, tem função instrumental de gerir os interesses da sociedade, e deve assumir, em primeiro lugar, a responsabilidade pelo indivíduo incapaz desatendido pelos pais, em nossos dias. $\mathrm{O}$ Estado assume a primeira posição na rede protetora de pessoas. Mas nem por isso deve manter-se como executor exclusivo da função de zelar pela situação do menor de idade, porque não compete a ele incumbir-se sozinho de tarefas cujas competência originária era de outros agrupamentos (família e sociedade civil) ou cuja competência concorrente (ou comum) deva com eles compartilhar". PEREIRA JÚNIOR, Antônio Jorge. ob. cit. pp. 165-166. 
pertinência entre os instrumentos de intervenção, as razões que legitimam a sua utilização e os objetivos visados, sempre considerando a preservação da autonomia da entidade familiar, ${ }^{41}$ (que de todo modo não é absoluta). Tal ingerência não pode, por óbvio, redundar em totalitarismo e é exercida, principalmente, pelo Ministério Público e pelo Poder Judiciário ${ }^{42}$.

Aliás, os artigos 1.631, parágrafo único do Código Civil, e 21, do Estatuto da Criança e do Adolescente, estabelecem que no exercício do poder familiar, havendo divergência entre os pais, qualquer um deles poderá levar a controvérsia ao Juiz para a solução. Esse dispositivo legal é bastante representativo dos objetivos da ordem jurídica acerca da proteção do melhor interesse da criança pela família e pelo Estado.

Ora, mesmo em um ambiente familiar de ótima consideração e respeito entre os membros, pode haver, de acordo com as posições pessoais de cada um, efetiva discordância entre os pais quanto a questões relevantes ligadas à criação dos filhos, que se indefinidas de modo permanente poderiam acarretar patentes prejuízos à prole, razão pela qual se faz plenamente justificável a atuação estatal em casos de impasse.

O maior problema em tal contexto é calibrar a maneira de agir por parte do Juiz, para que não se criem conflitos indesejáveis no seio familiar, o que acabaria por acarretar, igualmente, danos aos filhos. Ideal é que o Juiz busque a conciliação entre as partes, inclusive com apoio de psicólogos e assistentes sociais nas situações em que isto seja recomendado $^{43}$. O Magistrado deve, desse modo, procurar entender as relações familiares de maneira global, e não apenas pontual.

Essa maneira de proceder tem como objetivo proteger mais efetivamente os interesses dos menores e incutir nos pais a ideia de que a tomada de uma ou outra posição

${ }^{41}$ Idem. p. 172.

42 SCAFF, Fernando Campos. "Considerações sobre o Poder Familiar". In: CHINELLATO, Silmara Juny de Abreu; SIMÃO, José Fernando; FUJITA, Jorge Shiguemitsu; ZUCCHI, Maria Cristina. Direito de familia no novo milênio. Estudos em homenagem ao Professor Álvaro Villaça Azevedo. São Paulo: Editora Atlas S.A., 2010. pp. 571-582. p. 575.

43 "Vale salientar, mesmo que a intervenção judicial se caracterize como efetiva ingerência no âmbito da autonomia familiar, o certo é que ela existirá apenas em momentos de especial e excepcional vulnerabilidade, colocando-se o juiz como terceira pessoa supra partes, que respeitará evidentemente, e dentro do possível, a autonomia da família padecente de conflito insanável por suas próprias forças. Além do que, dependendo da natureza do conflito apresentado, pode ser que a intervenção judicial seja o caminho único para a manutenção da integridade efetiva da família. E não há que querer preservar a autonomia de uma família se ela não lograr manter sua coesão e unidade pela dinâmica própria. Some-se a isso que o poder familiar é um munus público, de modo que não somente é admissível como também inafastável, quando houver violação das normas a que deve subsumir-se, a intervenção judicial". COMEL, Denise Damo. ob. cit. pp. 232-233. 
não significa o melhor preparo do genitor que teve a sua opinião aceita, mas sim o fruto de uma decisão construída com a participação importante de ambos (e, se possível e pertinente, do menor envolvido) e que sirva como paradigma nos casos conflituosos futuros.

Ressalta-se que o modelo da tutela, atuante nas situações em que estejam privados do poder familiar o pai e (ou) a mãe, tenham falecido ou sejam ausentes ${ }^{44}$, segue as mesmas diretrizes de proteção integral do melhor interesse da criança e do adolescente, tendo em vista que o próprio Código Civil, em seu artigo 1740, "caput" e incisos, fixa os deveres e poderes do tutor que, de modo geral, assemelham-se àqueles relativos ao poder familiar.

Todavia, a tutela, por ser, expressamente, um "munus" público e por não ser baseada em uma presumida relação de afeto entre pais e filhos, sofre maior intervenção do Estado quanto ao seu exercício, submetendo o tutor a um controle maior, efetuado pelo Poder Judiciário e pelo Ministério Público. É o que ocorre, por exemplo, com a exigência de maiores cautelas quanto à venda dos bens do tutelado, a necessidade de prestação de contas pelo tutor, dentre outras ${ }^{45}$.

Em realidade, a abordagem procedida pela lei busca garantir, por um lado, a ampla e prioritária proteção dos interesses dos menores e, por outro, resguardar o próprio tutor que, nas decisões mais complexas, pode ser substituído institucionalmente pelo Estado.

Portanto, não se deseja estabelecer uma total e permanente ingerência do ente Estatal sobre a atuação dos pais no direcionamento das vidas de seus filhos, mas tão somente dotar a ordem jurídica de mecanismos que permitam ao Estado e à sociedade monitorar o desenvolvimento dessas relações, notadamente naquelas situações mais intrincadas em que estejam envolvidos direitos e bens de especial relevo. A preocupação é exatamente evitar, ou afastar de maneira célere, eventuais prejuízos que possam ter consequências indeléveis na vida de crianças e adolescentes. Busca-se preservar o interesse dos menores sempre com base no cuidado que deve pautar os casos em que estejam envolvidos.

44 PEREIRA, Caio Mário da Silva. "Instituições de Direito Civil”. v. 5, Direito de Família, 16ª ed., Atualizado por Tânia Silva Pereira. Rio de Janeiro: Forense, 2006. p. 443.

45 ELIAS, Telma de Melo. ob. cit. p.96. 


\subsection{O cuidado como pressuposto do atendimento do melhor interesse do menor}

A ideia de cuidado, princípio não expresso, mas que permeia toda normatização trazida pela Constituição e mesmo pela legislação infraconstitucional, possibilita a concretização das medidas adequadas e necessárias à proteção integral da criança.

O cuidado, como expressão da ética da responsabilidade, está relacionado à própria existência humana em sociedade, remetendo-se à ideia de alteridade, de respeito e adoção de condutas que permitam o pleno desenvolvimento dos demais seres humanos ${ }^{46}$.

Pode-se dizer que o cuidado, adicionalmente, é expressão da caracterização da proteção da integridade e dignidade do homem como principal bem a ser protegido por qualquer ordem constitucional democrática, o que, aliás, vem expresso em nossa Carta Magna $^{47}$.

A noção de cuidado, além disso, visa a resguardar a igualdade entre as pessoas, na medida em que pressupõe a tomada de atitudes que tenham por escopo proteger a condição humana de acordo com seu mínimo existencial, como ressaltado, sem discriminações de qualquer ordem, a não ser aquelas relacionadas à eliminação de eventual e peculiar vulnerabilidade ${ }^{48}$.

Aliás, a vulnerabilidade da criança, em que eventuais danos produzidos são

46 "É preciso identificar o cuidado dentre as responsabilidades do ser humano como pessoa e como cidadão; em nome do interesse público, exige-se do ser humano uma postura ética, a ética da co-responsabilidade que se fundamenta na solidariedade e na cidadania. O cuidado deve, assim, conduzir a efetivos compromissos, remetendo à idéia de alteridade. O cuidado representa uma atitude de ocupação, de preocupação, de responsabilização e de envolvimento com o outro, daí sua essência humana". GAMA, Guilherme Calmon Nogueira da. "A parentalidade responsável e o cuidado: novas perspectivas". In: Revista do Advogado, Ano XXVIII, no 101, São Paulo: AASP, dez. 2008. pp. 29-36. p. 29.

47 "A subordinação da realidade política, económica e cultural aos valores da pessoa humana, sem desvalorizar a componente social do homem, nem reduzir-se a um dissimulado individualismo egoísta, aponta um personalismo constitucional que faz da dignidade de cada pessoa humana viva e concreta o fundamento de validade de toda a ordem jurídica e razão de ser do Estado: é a dignidade da pessoa humana viva e concreta e os direitos fundamentais dela decorrentes que justificam o Estado e a Constituição e não o Estado ou a Constituição que outorgam os justificam a dignidade da pessoa humana e os direitos humanos". OTERO, Paulo. "Pessoa Humana e Constituição: contributo para uma concepção personalista do Direito Constitucional". In: CAMPOS, Diogo Leite de; CHINELLATO, Silmara Juny de Abreu (coords). Pessoa Humana e Direito. Coimbra: Almedina, 2009. pp. 349-380. p. 355.

48 "Neste último domínio [dos direitos sociais universais], a preocupação de garantir uma tutela mais eficaz e ampla da pessoa humana tem justificado o reconhecimento de direitos especiais a categorias específicas de indivíduos: é o que sucede quando se fala, por exemplo, em direitos dos trabalhadores, direitos da juventude, direitos do estudante, direitos dos idosos. Nunca poderá um tal fenómeno, todavia, ser perturbador do cerne do princípio da igualdade, criando privilégios infundados ou injustificados numa mesma sociedade". Idem. p. 368. 
potencializados e com maiores chances de se tornarem irreversíveis, embasa de maneira consolidada a adoção de medidas, prévias ou consequentes, que evitem ou minorem os efeitos desses prejuízos, quer proibindo certas atividades, quer restringindo e controlando de modo próximo à realização de outras, em verdadeira atitude de precaução e cuidado.

No caso da família, não há dúvida de que a estabilidade da convivência neste âmbito é valor a ser preservado, constituindo norma orientadora primordial da proteção da criança. A própria autoridade dos pais deve ser garantida, desde que sirva como instrumento do desenvolvimento da personalidade do menor e da proteção do melhor interesse dele.

Todavia, no caso concreto, é possível deparar com situações em que a manutenção do menor no seio familiar não seja recomendável, ou mesmo que o desejo dos pais deva ser rejeitado, em atendimento a outros interesses daquele que se mostrem mais importantes.. Assim é que pode ser vislumbrada a existência de relevantes meios legais para a solução desses problemas, e que serão tratados no terceiro capítulo. Leva-se em conta, no estabelecimento destas medidas, exatamente, o cuidado que se deve ter em relação ao menor, protegendo, acima de tudo, a integridade física e psíquica ${ }^{49}$ dele.

Ter em mente a noção de cuidado $^{50}$ como vetor e eixo principal de proteção à

49 “De qualquer forma, é preciso que a criança seja provida das funções maternas e paternas para que possa se desenvolver. A função paterna de proteger a criança ao mesmo tempo que impõe os interditos sociais (respeito, educação, crimes), contracena com a maternagem. Assim, não resta dúvida de que a criança e o adolescente possuem o direito de crescer no seio familiar, nos termos do artigo 19, da Lei no 8.069/1990, sendo que tal diretriz pode ser mitigada em face de violações dos seus direitos e garantias por parte dos responsáveis, os quais devem atender, de qualquer forma, ao melhor interesse da criança e do adolescente (viés interpretativo, ECA, art. $6^{\circ}$ ), o qual somente pode ser apurado a posteriori, ou seja, não se trata de um a priori, no sentido kantiano. Deve-se cotejar normativamente, em cada caso, qual dos Direitos Fundamentais (Ferrajoli) deve preponderar, superando, claro, a postura de ponderação. Isso porque o direito de convivência familiar não se pode dar ao preço do vilipêndio dos direitos e garantias da criança e do adolescente. Ambos são Direitos Fundamentais e, em caso de choque, deve ser aplicado o melhor interesse a partir do critério a se estabelecer ao sistema normativo, a saber, o cuidado. Trata-se, pois, de aparente conflite entre bens constitucionalmente protegidos. Em tais casos, há que se optar por aquele que se revela de maior proeminência em face do critério adotado (cuidado), informado, evidente, pela perspectiva da criança e do adolescente. Nessa linha de entendimento que o direito à vida (boa) é de maior magnitude do que o poder familiar irrestrito. De sorte que quando estão em colisão o direito dos genitores, da família biológica e da criança, deve-se levar em conta o critério do cuidado, entendido para além das questões objetivas, mas especialmente subjetivas da filiação" (grifo do autor). ROSA, Alexandre Morais da. "O cuidado como critério do princípio do melhor interesse da criança". A questão da destituição do poder familiar. In: Revista do Advogado, Ano XXVIII, n 101. São Paulo: AASP, dez. 2008. pp. 7-13. p 12.

50 Denise Damo Comel, não se referindo à expressão "cuidado", mas se abeberando do artigo 227, da Constituição Federal, ensina, no âmbito do poder familiar, que o dever de assistir como "a primeira obrigação dos pais com relação aos filhos menores, deve ser compreendido como uma declaração programática do que constitui o poder familiar. O preceito [artigo 227] deixa claro que a obrigação dos 
criança e ao adolescente, que possibilita a identificação da mais adequada opção com vistas a preservar o melhor interesse do menor, e de modo prioritário, torna possível adotar as cautelas e medidas adequadas à consecução do objetivo proposto.

Soma-se a isso, como elemento justificador de tal atitude de precaução, o fato de que a autonomia do menor, mais restrita, está sujeita à vontade de outrem, quer sejam seus pais, quer sejam seus tutores, ou outros responsáveis legais, como v.g. guardiães, podendo haver nesta situação uma tal fusão de escopos em que não se possa perceber, de antemão, se estão sendo considerados verdadeiramente os interesses atinentes à criança de modo prioritário ou se se está atendendo à mera vontade dos responsável.

Não se pode olvidar, que as crianças não possam, sob qualquer hipótese, ser utilizadas como meros meios de satisfação de terceiros. Em vista disso, deve-se levar em conta, sempre, primeiramente, o bem estar e integridade, presentes e futuros, da própria criança ou adolescente envolvidos, ainda que, secundariamente, haja o atendimento de interesses de outrem, ou mesmo da sociedade de uma forma geral.

Considerando as noções de cuidado e de melhor interesse, portanto, há que se ter responsabilidade frente aos menores, devendo ser adotadas todas as medidas, prévias ou não, preventivas e de precaução ou sancionatórias, para que se atinja, acima de tudo, a proteção integral da criança e do adolescente e de seu sadio desenvolvimento.

\subsection{A positivação do cuidado e da proteção integral do melhor interesse da criança e do adolescente no Ordenamento jurídico brasileiro}

Evidente medida de cuidado no que tange ao atendimento do melhor interesse da criança é o dever jurídico estabelecido pelo Estatuto da Criança e do Adolescente - ECA em seus artigos $28, \S 1^{\circ}$, e 168 , de oitiva do menor, sempre que possível, e respeitadas as

pais é extremamente abrangente, obrigando-os a estar presentes na vida do filho, ativa e diuturnamente, numa postura de ação e integração, prestando-lhe assistências de toda a ordem. Veja-se que o dever de assistir não tem fim em si mesmo, senão que abarca ampla gama de funções, em que se incluem todas aquelas que são específicas e precípuas do poder familiar, quais sejam, o dever de criar, o dever de educar, o dever de ter em companhia e guarde e o dever de representação e assistência, que serão estudados a seguir. Assim, pois, o dever de assistir será cumprido à medida que os pais assumirem todos os encargos com relação aos filhos, dando-lhes o suporte necessário ao pleno desenvolvimento da personalidade deles". ob. cit. pp. 94-95. Vê-se, pois, que as noção de dever de assistência e de cuidado possuem entre si uma identidade de conteúdos, ambos refletindo uma mesma realidade jurídica destinada a guiar a conduta dos responsáveis pela garantia do bem-estar físico e psíquico das crianças e adolescentes, quer no seio familiar, quer fora dele. 
suas condições peculiares de desenvolvimento. A legislação civil determina que a plena capacidade só é adquirida, desde que não haja nenhuma deficiência psíquica, aos 18 anos, além de considerar absolutamente incapaz o menor que não possua 16 anos completos.

O ECA, definindo como criança os menores de 12 anos, e adolescentes aqueles que possuam idade entre 12 e 18 anos, ao dispor da forma acima citada, procura inserir o menor, que normalmente não teria condições legais de exercer a sua vontade, nos processos decisórios que atinem aos seus direitos existenciais. Trata-se de medida elogiável e que deve ser plenamente exercida e incentivada.

Por consequência, como não poderia deixar de ser, pela intimidade e ligação de afeto que possuem com os filhos, os pais são os primeiros e, salvo situações excepcionais, os perenes responsáveis em salvaguardar os direitos ${ }^{51}$ do menor. Para tanto, devem pautar sua conduta de modo a dar preponderância, sobre todos os outros interesses eventualmente existentes, à proteção do desenvolvimento digno e sadio dos menores.

O Estatuto da Criança e do Adolescente é repleto de disposições normativas gerais voltadas à proteção integral ${ }^{52}$, intimamente ligada à noção do atendimento do melhor interesse da criança ${ }^{53}$. Em outras palavras, a finalidade do ordenamento, da sociedade, do

51 "O tipo de responsabilidade que se mostra vitalícia - ou quem sabe perpétua nas pessoas dos descentes atuais e futuros - vincula a pessoa a situações jurídicas existenciais e patrimoniais relacionadas ao seu filho, a sua descendência. Desse modo, a consciência a respeito da paternidade e da maternidade abrange não apenas o aspecto voluntário da decisão - de procriar -, mas especialmente os efeitos posteriores ao nascimento do filho, para o fim de gerar a permanência da responsabilidade parental principalmente nas fases mais importantes de formação e desenvolvimento da personalidade da pessoa humana: a infância e a adolescência, sem prejuízo logicamente das consequências posteriores relativamente aos filhos na fase adulta - como os alimentos entre parentes. Tal deve ser a consideração a respeito do sentido da parentalidade responsável, o que de certo modo se associa aos princípios da Dignidade da Pessoa humana e do Melhor Interesse da Criança e do Adolescente, dentro de uma perspectiva mais afetiva e social do que puramente biológica. Nessa acepção, a parentalidade responsável reporta-se à noção de cuidado em sua dimensão ontológica, ou seja, à idéia de que a pessoa humana é um ser consciente e live, que está no mundo com os outros, voltado para o futuro, precisando ser cuidado para viver e sobreviver, mas também cuidar dos outros, especialmente daquele que representarão sua continuidade como descendência". GAMA, Guilherme Calmon Nogueira da. ob. cit. p. 31 (grifo do autor).

52 "Exercendo importante função pedagógica e adotando o cuidado como princípio não expresso, mas fundamental e que emerge de suas diretrizes, o ECA introduziu normas da ordem jurídica, regulamentando os direitos à proteção integral - que compreende políticas sociais básicas, como saúde e educação - e à proteção especial, que inclui o resguardo contra toda forma de violência, além de um sistema para garantir esses mesmos direitos". TELLES, Marília Campos Oliveira; COLTRO, Antônio Carlos Mathias. "O Estatuto da Criança e do Adolescente: uma lei de gente grande". In: Revista do Advogado, Ano XXVIII, no 101. São Paulo: AASP, dez. 2008. pp. 70-76. p. 71.

53 "O Princípio do Melhor Interesse da Criança exige ser plenamente implantado e observado na ordem jurídica nacional não apenas como princípio geral, mas como critério de interpretação e de aplicação da norma jurídica nas questões relacionadas à criança e ao adolescente.- a exemplo do que se verifica no Direito Inglês e no direito norte-americano, com a diferença de que ele deve ser apreendido em todos os vínculos jurídicos relacionados à criança e ao adolescente, inclusive no seu cotidiano, o que envolve as 
Estado e da família deve ser a salvaguarda dos direitos especiais de que são titulares os menores, em razão da sua peculiar condição de pessoa em desenvolvimento ${ }^{54}$.

Como direitos essenciais, ou fundamentais, da Criança e do Adolescente carreados pelo Estatuto da Criança e do Adolescente, quatro se mostram mais importantes para o nosso trabalho, no que se referem às pesquisas clínicas, quais sejam o direito à vida, o direito à saúde, o direito à liberdade e o direito à dignidade.

Os dois primeiros são expressamente nomeados nos artigos $7^{\circ}$ e ss. do Estatuto ${ }^{55}$, e os terceiro e quarto nos artigos 15 e ss da mesma codificação ${ }^{56}$. Observe-se que tais direitos veem também expressamente previstos na Constituição Federal, em seu artigo 227, estabelecendo a prioridade absoluta na sua proteção ${ }^{57}$, como, aliás, já foi aqui consignado.

É evidente que o direito à vida é o principal e primeiro a ser protegido, na medida em que "a ausência dele nada significa, pois o viver é o existir. Sem a existência do titular dos diretos fundamentais, todos os demais perdem a razão de ser" ${ }^{\prime 58}$.

Contudo, essa vida, como dito anteriormente, possui características especialíssimas que devem ser priorizadas a fim de alcançar a proteção integral e efetiva. Não basta a existência de uma vida, mas sim uma vida qualificada pela salubridade de desenvolvimento físico e psíquico, pela dignidade, enfim, composta pelos demais direitos protegidos. Garante-se, dessa forma, o início da vida, bem como a sua posterior existência,

relações paterno-materno-filiais. GAMA, Guilherme Calmon Nogueira da. ob. cit. p. 33.

54 "Portanto, a família não tem apenas direito, mas também deveres de assegurar, juntamente com o Estado e a sociedade, os direitos fundamentais da criança e do adolescente, conforme determinação do art. 227 da Magna Carta, tais como o direito à vida, à saúde, à alimentação, à educação, ao lazer, à profissionalização, à cultura, ao respeito, à liberdade, e, principalmente, à dignidade e convivência familiar. Desta forma é dever dos pais colocar os filhos a salvo de qualquer forma de negligência, discriminação, exploração, violência, crueldade e opressão". CASSETARI, Christiano. "Responsabilidade civil dos pais por abandono afetivo de seus filhos - dos deveres constitucionais". In: Revista IOB de Direito de Família, v. 9, n 50, out./nov. 2008. Porto Alegre, 2008. pp. 87-99. p.91.

55 Art. $7^{\circ} \mathrm{A}$ criança e o adolescente têm direito a proteção à vida e à saúde, mediante a efetivação de políticas sociais públicas que permitam o nascimento e o desenvolvimento sadio e harmonioso, em condições dignas de existência.

56 Art. 15. A criança e o adolescente têm direito à liberdade, ao respeito e à dignidade como pessoas humanas em processo de desenvolvimento e como sujeitos de direitos civis, humanos e sociais garantidos na Constituição e nas leis.

57 Art. 227. É dever da família, da sociedade e do Estado assegurar à criança, ao adolescente e ao jovem, com absoluta prioridade, o direito à vida, à saúde, à alimentação, à educação, ao lazer, à profissionalização, à cultura, à dignidade, ao respeito, à liberdade e à convivência familiar e comunitária, além de colocá-los a salvo de toda forma de negligência, discriminação, exploração, violência, crueldade e opressão.

58 LAMENZA, Francismar. ob. cit. p. 47. 
de maneira autônoma, sadia e digna ${ }^{59}$.

A pertinência de qualquer atividade levada a efeito pela família, pelo Estado e pelos integrantes da sociedade, dessa maneira, será avaliada tendo por base exatamente ser ou não adequada ao atendimento dos direitos acima assegurados pela ordem jurídica Tal análise será primordial para se determinar em que proporção haverá responsabilidade por eventual insucesso na consecução de tais tarefas, causado omissiva ou comissivamente pelos entes acima referidos.

\subsection{O Ministério Público como ente garantidor dos direitos dos menores}

O Ministério Público vem previsto está concebido na Constituição Federal como instituição exercente de função essencial à justiça, tendo a incumbência, segundo o artigo 127, "caput", de defender a ordem jurídica, o regime democrático e os interesses sociais e individuais indisponíveis. Além disso, possui autonomia funcional ${ }^{60}$ e administrativa, segundo o $\S 1^{\circ}$ do mesmo dispositivo, bem como é dotado de inúmeras prerrogativas para a garantia do efetivo exercício das atribuições acima enumeradas. Um exemplo de tais atribuições, na área cível, é promover Ação civil pública e o Inquérito civil, com a possibilidade ampla de requisitar documentos e informações dos diversos entes públicos e privados.

59 "Outras medidas de proteção à criança e ao adolescente, que objetivam o seu desenvolvimento sadio e harmonioso, são encontradas nos artigos 81 e 82 do ECA. Consistem na proibição de venda à criança e ao adolescente de armas, munições e explosivos; bebidas alcoólicas; produtos cujos componentes possam causar dependência física ou psíquica ainda que por utilização indevida; fogos de estampido e de artifício, exceto aqueles que pelo seu reduzido potencial sejam incapazes de provocar qualquer dano físico em caso de utilização indevida; revistas e publicações a que alude o artigo 78 do ECA; bilhetes lotéricos e equivalentes. Ademais é proibida a hospedagem de criança e adolescente em hotel, motel, pensão ou estabelecimento congênere, salvo se autorizados ou acompanhados pelos pais ou responsável. Aqui se cuida, especificamente, da hospedagem ligada a relacionamento sexual. São medidas de salvaguarda dos interesses da criança e do adolescente, adotadas com fundamento no princípio da sua proteção integral". ELIAS, Telma de Melo. ob. cit. p. 68.

60 Ainda que seja questão de somenos importância, tendo em vista que o Ministério Público, como constatado, possui ampla autonomia, a maior parte da doutrina, (v.g. SILVA, José Afonso da. Curso de Direito Constitucional Positivo. 33 ${ }^{\mathrm{a}}$ ed. Sâo Paulo: Malheiros Editores, 2010. p. 598), em termos organizacionais, enquadra-o como vinculado ao Poder Executivo. Para uma análise mais completa, cf. LIMA, Fernando Antônio Negreiros. A intervenção do Ministério Público no Processo civil brasileiro como 'custos legis'. São Paulo: Método, 2007. pp. 86-96. 
A instituição ora tratada é composta pelo Ministério Público da União, integrado pelo Ministério Público do Trabalho, o Federal, o Militar e o do Distrito Federal e Território, e pelo Ministérios Públicos dos estados, sendo o respectivo âmbito de atribuições materiais definido de acordo com a competência do Órgão jurisdicional perante o qual atuam. Assim, exemplificativamente, o Ministério Público Federal, em regra, atua naquelas situações cuja análise seja de competência da Justiça Federal.

Portanto, trata-se de órgão constitucionalmente delineado para a proteção dos direitos fundamentais, individuais ou sociais, o que afasta qualquer tipo de ingerência ou pressão política no desenvolvimento de suas atividades.

Com o objetivo de alcançar o melhor cumprimento dessa missão, devem os seus membros estar sempre bem informados acerca da realidade nacional quanto às áreas de atuação. Dessa maneira, torna-se possível estabelecer uma constante e intensa aproximação entre a Instituição e a sociedade civil.

O Ministério Público, ao contrário do que normalmente deve ocorrer com o Poder Judiciário, não é inerte à espera de provocação. Imprescindível que a sua atuação se efetue de maneira oficiosa, utilizando-se de todos os instrumentos necessários, adequados à efetivação das atribuições que a ele competem. É verdadeiro órgão de fiscalização do cumprimento dos direitos fundamentais, tanto no domínio público, quanto no privado. Não pode ser movido por interesses próprios, corporativistas, mas somente pela necessidade de resguardar os direitos fundamentais de todas as pessoas, especialmente dos menores, com reflexão e ponderação, considerados de maneira individual ou sob o aspecto coletivo ou difuso $^{61}$. Finalmente, consubstancia o paradoxo de ser a parte imparcial.

O Estatuto da Criança e do Adolescente, através do artigo 201, especializa a caracterização constitucional do Ministério Público quanto à proteção dos direitos dos menores. Também eleva-o ao papel de maior protetor dos direitos fundamentais das crianças e adolescentes $^{62}$ e estabelece amplos poderes a esta instituição e aos seus membros no sentido de preservar e promover o atendimento com absoluta prioridade do

61 MAZZILI, Hugo Nigro. "O Ministério Público e o Estatuto da criança e do adolescente”. In: Revista de Informação Legislativa. Ano 29, n 114, abr/jun 1992. Brasília: Senado Federal, 1992. pp. 157-198. p. 162.

62 FERREIRA, Lucia Maria Teixeira.; BITTENCOURT, Sávio Renato. “As políticas públicas e o Ministério Público como agentes garantidores do direito à convivência familiar e comunitária de crianças e adolescentes abrigados". In: Revista do Advogado. Ano XXVIII, no 101, dezembro de 2008. São Paulo: AASP, 2008. pp. 62-69.p. 64. 
melhor interesse das crianças e adolescentes, inegavelmente uma de suas primordiais finalidades, segundo o inciso VIII ${ }^{63}$. Há ainda o $\S 2^{\circ}$ do dispositivo em comento que fixa uma verdadeira cláusula de abertura, ao dispor que as atribuições constantes no artigo não excluem outras, desde que compatíveis com a finalidade do Ministério Público.

Observa-se que a atuação do Ministério Público pode ocorrer de maneira preventiva e repressiva, dando-se principalmente naqueles casos em que o menor não esteja amparado pela sua família, ou ainda quando houver colisão entre os interesses emanados dos membros desta, notadamente os pais, e aqueles atinentes à criança ou ao adolescente.

O "parquet”, judicialmente e na área cível, possui a atribuição de promover as ações de responsabilidade contra aquelas pessoas envolvidas na violação de direitos dos menores, inclusive seus genitores, tendo em vista que essa atribuição se conforma adequadamente a sua feição constitucional acima delineada.

Sem deixar de considerar a importância da avaliação dos poderes e funções do Ministério Público no aspecto processual, o presente tópico foca a sua análise na atuação prévia de tal órgão como fiscalizador da adoção de medidas que visem a evitar danos às crianças e adolescentes.

Necessário frisar novamente que, por gozar da condição de pessoa em desenvolvimento, qualquer atividade que ponha em risco os menores pode acarretar consequências sérias, com o comprometimento substancial do processo de amadurecimento em que se insere, as quais podem repercutir mais tarde na vida adulta.

Tomando por base a constatação acima, a atuação preventiva é aquela que se mostra mais adequada e recomendada no sentido de assegurar a proteção dos direitos da criança e do adolescente. É óbvio que, em qualquer caso, evitar o dano é sempre melhor que o remediar, contudo, no que concerne aos interesses dos menores, esta afirmação

63 “A norma do inciso VIII do art. 201 do Estatuto é um desdobramento do art. 29, II, da Constituição da República. Com efeito, o papel do Ministério Público, nesses casos, é de verdadeiro ombudsman, podendo e devendo, nesse campo, receber petições, reclamações ou representações das pessoas e entidades interessadas; investigar as denúncias recebidas até mesmo pela imprensa; visitar estabelecimentos de toda a natureza, onde estejam ou possam estar crianças e adolescentes; atentar para as propagandas de produtos nocivos à sua saúde ou à sua segurança; exigir das autoridades públicas não só uma adequada política educacional e de saúde, como investimentos adequados; fiscalizar os gastos públicos com campanhas, construção de escolas e estabelecimentos próprios; denunciar na imprensa as irregularidades noticiadas; promover em juízo a responsabilidade dos particulares, das autoridades ou das pessoas jurídicas que, por ação ou omissão, causem dano a qualquer interesse defendido no Estatuto ou em qualquer norma de proteção à infância e juventude". MAZZILI, Hugo Nigro. ob. cit. p.191. 
ganha especial relevo.

Dessa forma, o sistema normativo deve possuir como objetivo garantir o melhor desenvolvimento das ações do Ministério Público naquelas situações em que, potencialmente, esteja em risco a incolumidade dos menores, quer por que expostos bens sensíveis destes, quer por haver a possibilidade concreta de prevalência de interesses que não correspondam àqueles titularizados pelas crianças e adolescentes. Em tal contexto, deve ser oportunizado à instituição tratada uma participação direta nos debates e decisões acerca do cabimento e da conveniência das atividades a serem desenvolvidas, o que permitiria a este ente um efetivo controle de tais atividades, sempre com vistas à proteção integral e com absoluta prioridade do melhor interesses dos menores.

No caso adiante analisado, relativo à participação de crianças e adolescentes em pesquisas clínicas, por estarem envolvidos tanto a preservação da saúde delas quanto o grau de maior risco que essas atividades representam, em comparação à administração de tratamentos médicos ou farmacêuticos cujas consequências já estão consolidadas, torna-se clara a necessidade afirmada de estabelecimento de mecanismos preventivos, o que inclui, como se analisará, a participação efetiva do Ministério Público. 


\section{PESQUISAS CLÍNICAS}

\subsection{Bioética}

\subsection{1. Ética e direitos humanos}

2.1.1.1. Ética: evolução do conceito e fundamento

Diz-se que o fator diferencial do homem em relação aos outros animais é ser dotado de racionalidade. Não há dúvidas acerca da correção dessa assertiva, desde que esteja o problema centrado, em realidade, na definição do que representa essa denominada racionalidade.

Pode-se inferir que a racionalidade consiste na capacidade do ser humano em se reconhecer como ente inserido no processo natural de vida, ao mesmo tempo não submetido aos limites estritos dele, apto a observá-lo sob um enfoque externo, reproduzi-lo e superá-lo, em certa medida ${ }^{64}$.

O homem, assim, caracteriza-se por não se submeter ao meio que o cerca sem qualquer tipo de indagação ou mudança dos rumos estabelecidos pelo processo natural. Como indivíduo produz a própria história, relacionando-se com os demais seres, principalmente seus pares, autodeterminando-se de acordo com os valores tidos como positivos pelo grupo social ao qual pertence, e que por isso convertem-se em finalidade de seu agir. Outra postura é a de compreender a si próprio, dessa maneira, como único ser dotado de valor intrínseco ${ }^{65}$.

Pode-se refletir, contudo, acerca de, basicamente, duas concepções de racionalidade, cujo enfoque se dá em um ou outro aspecto da ideia anteriormente desenvolvida, e que travam um embate constante no curso da história da humanidade.

64 "A grande especificidade do gênero humano reside no fato de que, embora produto e elemento integrante da biosfera, ele passou a alterá-la decisivamente no curso do processo evolutivo, e tornou-se, afinal, capaz de interferir na geração e sobrevivência de todas as espécies vivas". COMPARATO, Fábio Konder. Ética: direito, moral e religião no mundo moderno. $3^{\text {a }}$ reimpr. São Paulo: Companhia das Letras, 2006. p. 29.

65 "O homem é o valor fundamental, algo que vale por si mesmo, identificando-se seu ser com a sua valia. De todos os seres, só o homem é capaz de valores, e as ciências do homem são inseparáveis de estimativa". REALE, Miguel. Filosofia do Direito. $20^{\mathrm{a}}$ Ed, $8^{\mathrm{a}}$ tir. São Paulo: Saraiva, 2002. p. 210. 
De um lado, existe a racionalidade, caracterizada, de maneira mais marcante, pela aptidão do ser humano em observar a natureza, reproduzi-la e até mesmo superá-la, por meio do domínio da ciência e da técnica, respectivamente. Essa concepção, fruto da mais remota curiosidade humana, foi aperfeiçoada e aprofundada com o movimento iluminista, que se refletiu, no âmbito da política, no liberalismo, e da economia, no capitalismo.

Inegável que nos movimentos supracitados é dado ao homem um alto grau de liberdade para a realização das atividades que lhe competem, bem como é incentivado à busca incessante pelo progresso técnico e científico. Ambas as situações, em realidade, servem de maneira adequada aos propósitos de irrefreável consumo e aumento perene da capacidade de produção dos bens que irão alimentar esse mesmo consumo. Nesse aspecto, estabelece-se um movimento cíclico, cujo objetivo é consolidar a expansão constante do capitalismo.

Por outro lado, há outra concepção cujo alicerce se funda na tese de que a racionalidade se identifica com a igualdade material e a possibilidade da organização da vida em sociedade entre os homens. Em tal acepção, ficam estabelecidos certos fins axiológicos comuns e os instrumentos necessários para o alcance e concretização destes, tentando-se compatibilizar as diversas manifestações volitivas dos componentes dos vários grupos. A proteção do homem e de sua autonomia, concreta e individualmente considerada, deve ser a referência necessária de qualquer atividade levada a cabo pelos membros da sociedade. $\mathrm{O}$ avanço científico e, mais fortemente, o técnico encontram-se condicionados e limitados pelos fatores anteriormente aduzidos.

A abordagem foi muito bem sistematizada, abstrata e concretamente, na Grécia e Roma, respectivamente, na medida em que essas civilizações, sem se abandonar a observação da natureza e a busca por algum avanço técnico, deram especial relevo à reflexão acerca da organização social, política e jurídica da sociedade. À mesma proporção, houve a implementação dos mecanismos adequados ao estabelecimento das melhores formas desta organização. Há que se ressalvar que, nas civilizações citadas, o conceito de pessoa, merecedora de proteção especial e dotada de autonomia, não coincide com aquele de ser humano, já que apenas a pequenos e seletos grupos de homens eram conferidos, pela organização social e jurídica, tal atributo.

O que se percebe é que, na sucessão dos períodos históricos, os posicionamentos acima delineados revezam-se na primazia, sem isto significar, contudo, o desaparecimento 
da ideia contrária no que se refere à racionalidade, ainda que com menos força em virtude das condicionantes reais. A perene tensão entre ambas as concepções leva à construção de posições intermediárias e conciliatórias. Aliás, o radicalismo de uma ou outra acepção acaba sendo atenuado por esse constante processo dialético. É o que se verifica atualmente na contradição existente entre a expansão do capitalismo e os limites de sustentabilidade comportados pelo planeta.

A diversidade do tratamento da racionalidade acima estudada se reflete na incessante disputa por prevalência entre as ciências ditas positivas, que se ocupam dos objetos naturais e físicos principalmente ${ }^{66}$, cuja base explicativa, obtida a partir da observação da realidade constante (e que podem posteriormente ser transformadas em modo de ação, pelo domínio da técnica) funda-se nas relações de causalidade entre os diversos fenômenos, e as chamadas ciências culturais, cujo cerne está centrado naqueles objetos criados pelos homens para o manejo da vida em sociedade. As ciências incluídas nesta categoria baseiam suas assertivas em juízos de dever ser que condicionam o ser de maneira primariamente limitada, intermediados por certas pautas axiológicas. Ainda que se faça uma explicação baseada no princípio da causalidade, esta é, em realidade, mecanismo artificial, de mero controle das probabilidades, que se mostram mais ou menos consistentes de acordo com o ramo de estudo ${ }^{67}$.

A Ética e o Direito ${ }^{68}$ estão incluídas nesta última categoria estudada, consubstanciando ciências culturais compreensivo-normativas, na medida em que não se contentam com a observação das relações entre os homens, mas pretendem estabelecer, de modo imperativo, com suas conclusões, modos de agir a esses ${ }^{69}$, conforme certos valores e

66 A psicologia, em parte, também pode ser considerada uma ciência causal, mas a sua identificação com a tecnologia expansionista é menos clara do aquela verificada nas ciências mencionadas.

67 A redução conceitual efetuada é proposital, adequada aos limites do presente trabalho. Para um estudo bastante abrangente acerca das diferentes ciências e objetos de estudo, cf. REALE, Miguel. ob. cit.

68 No presente contexto, a palavra Direito pode ser compreendida como ramo científico e como realidade, ou objeto cultural, a ser estudado por este.

69 "Não basta dizer que a ciência do direito só deve ocupar-se com o que não é controverso: ela ficaria, então, na superfície formal do direito e não cumpriria o papel essencial de guia dos juízes em busca de soluções conformes ao direito e à eqüidade. Ela não pode cumprir esse papel sem a busca de justificações, que deixariam as decisões conformes à eqüidade e à segurança, ou seja, à justiça formal que exige que se trate da mesma forma situações essencialmente semelhantes. Mas, para alcançar esses fins, ela não pode dispensar argumentações que justificariam as soluções preconizadas. É o recurso a estas, à lógica jurídica por ela empregada, que explica as características próprias da deliberação, da motivação e do litígio em direito. Se se quisesse limitar a lógica jurídica à lógica formal, deformar-se-ia a própria realidade do raciocínio do s juízes e dos advogados". PERELMAN, Chaïm. Ética e direito. Trad. Maria Ermantina de Almeida Prado Galvão [rev. da trad. Eduardo Brandão]. 2ª ed. São Paulo: Martins Fontes, 2005. p. 419. 
cuja realização é tida como desejada. Buscam estas ciências converter certos fins em razões do agir.

O intérprete do Direito, ao efetuar a análise da ordem jurídica, depende de uma tomada de posição prévia, calcada exatamente em fatores axiológicos ${ }^{70}$. $\mathrm{Na}$ análise histórica e sociológica, ciências culturais não normativas, diferentemente, não se deseja incutir um modo de agir obrigatório, porém apontar que certas condutas humanas direcionadas ao alcance de valores redund(aram)am, provavelmente, em determinadas consequências $^{71}$.

A Ética, de um modo geral, portanto, é o estudo do bem agir em face de outros seres humanos e do meio em que vivem. Nessa linha, busca estabelecer, da mesma forma que o Direito, padrões de conduta que devem ser seguidos para o alcance de certos valores internalizados como desejáveis. De modo majoritário, entende-se a Ciência do Direito como um dos ramos da Ética, na medida em que se volta para a análise axiológica e imperativa da conduta humana sob um enfoque específico. Por consequência, o objeto cultural do Direito, ao lado da Moral, é realidade submetida à apreciação da Ética. Esta constatação, importante sublinhar, foi construída paulatinamente.

Pela natureza cambiável dos valores, na proporção em que não são dados e sim construídos ao longo do processo histórico de vivência humana, a Ética teve inúmeros conteúdos e acepções que foram constantemente superando-se ou somando-se no correr dos anos.

Em termos de desenvolvimento das relações sociais e dos ideários éticos que a governam, foi no chamado período axial, entre os séculos VIII a.C e 632 d.C (morte de Maomé) que ocorreram as mais profundas transformações econômicas, religiosas, filosóficas e políticas.

Antes desse período, a moral, o direito e a religião não possuíam uma distinção nítida entre si, sendo a vida social delineada, basicamente, pelos cultos e crenças religiosas. Além disso, cada diferente comunidade era isolada das demais, sem haver relevantes relações de troca entre estas. Cada qual possuía suas próprias organizações, baseadas em seus deuses particulares, incompatíveis com as demais.

70 REALE, Miguel. ob. cit. pp. 260 e ss.

71 Ainda que não haja neutralidade do cientista social ou historiador, as suas constatações não têm a pretensão e possibilidade de se tornarem diretamente vinculantes da ação humana, como ocorre na tarefa de interpretação das normas pelo jurista. 
Quando do início do período axial, o quadro se modifica, de maneira mais célere nas sociedades mediterrâneas, na medida em que cada vez mais os grupos locais se aproximam pelo desenvolvimento e espraiamento progressivos do comércio, dos instrumentos técnicos e dos consequentes desejos de conquista de novos territórios e poder. Esse movimento também teve reflexos no âmbito do direito, da moral e da religião, que tendiam a uma separação conceitual e de aplicação graças, principalmente, ao nascimento da filosofia e das primeiras religiões monoteístas universais. Nesse momento, cria-se uma certa tensão entre os ideários da razão, alcançados pela filosofia, e aqueles obtidos através da religião, baseados no sobrenatural, no inexplicável, ambos, porém, destinados à mesma tarefa: o governo da vida ética das pessoas ${ }^{72}$.

São traços marcantes da vida ética na antiguidade a importância fundamental da religião, o predomínio absoluto da tradição, a absorção do indivíduo pela coletividade e o desprezo sempre demonstrado pelos ofícios técnicos e pela profissão mercantil.

Observe-se que os povos antigos tinham como base não propriamente laços de sangue, mas sim os mesmos cultos religiosos aos deuses específicos do lar, característica que perdurou, ainda que de forma atenuada, durante a civilização greco-romana. Em Roma, por exemplo, o filho emancipado, ao deixar o lar, era considerado como “extraneus", sendo liberado do culto ao deus próprio de sua família original. Nota-se nesta fase histórica a importância da religiosidade atrelada ao culto aos mortos ${ }^{73}$.

Além disso, o respeito às instituições e regulamentações da vida em geral já consagradas é outro fator marcante na antiguidade. Os costumes, por serem fruto direto da tradição, gozavam de prestígio em face das leis escritas, o que conduz a uma ausência de separação clara entre a moral, o direito e a religião, e espraiavam sua normatização a todas as áreas da vida em sociedade, sejam elas religiosa, individual e familiar. É mister frisar que as leis escritas eram tidas não como fruto da vontade humana, mas tão somente como revelação de antigas normas já em vigor. A vida não se pautava por objetivos futuros, marcava-se pela convivência presente, baseada nos usos e costumes socialmente assentados e obedecidos sem uma criticidade acurada ${ }^{74}$.

Essas duas características acabam provocando a constatação da existência da

COMPARATO, Fábio Konder. ob. cit. p. 41.

Idem. pp. 50-51.

Ibidem. pp. 57-59. 
terceira, qual seja a absorção do indivíduo pela coletividade. A atribuição de direitos àquele tinha como referência legitimamente a qualidade de membro de um corpo político e não a autonomia privada. As normas tradicionais protegiam, regulando os pormenores da vida, a própria subsistência da sociedade e a convivência pacífica entre seus membros. Soma-se a isso, por fim, o desprezo pelas atividades mercantis e artesanais, consideradas vis na Grécia e em Roma, no comparativo com a atividade rural, justamente por se basear em relações de trocas artificiais, sem referibilidade natural ${ }^{75}$.

Deve-se ressalvar, todavia, o caráter universalizante do povo grego, não reducionista. Para esta civilização a ideia de justo ou injusto, certo ou errado, seria invariável, por conta de ir além, em sua teorização, de aspectos concretos ou relativos. Buscava-se o cerne geral das coisas, o que, aliás, se demonstra pelo nascimento da filosofia nos domínios daquele povo, com o intuito de atingir determinados conceitos e ideias gerais a respeito do homem, da vida e do mundo. Com esse movimento, é possível observar os primeiros sinais de aparecimento de uma ética racionalizada, como preceito obrigatório aos indivíduos sobre o modo de agir para o bem ${ }^{76}$. Não há, em tal período, nem mesmo no romano, uma sistematização clara nesse campo, entretanto, os primeiros sinais já estão ali.

Tanto a ética subjetiva, ou individual, quanto a objetiva, fundada no modo coletivo de vida, foram objeto de estudo dos gregos, porém, tanto em Aristóteles ${ }^{77}$ como

Idem ibidem. pp. 63-66.

76 "O homem é, por sua natureza, como dissemos desde o começo ao falarmos do governo doméstico e do dos escravos, um animal feito para a sociedade civil. Assim, mesmo que não tivéssemos necessidade uns dos outros, não deixaríamos de desejar viver juntos. Na verdade, o interesse comum também nos, pois cada um aí encontra meios de viver melhor. Eis, portanto, o nosso fim principal, comum a todos e a cada um em particular. Reunimo-nos, mesmo que seja só para por a vida em segurança. A própria vida é uma espécie de dever para aqueles a quem a natureza a deu e, quando não é excessivamente cumulada de misérias, é um motivo suficiente para permanecer em sociedade. Ela conserva ainda os encantos e a doçura neste estado de sofrimento, e quantos males não suportamos para prolongá-la! Mas não é apenas para viver juntos, mas sim para bem viver juntos que se fez o Estado, sem o quê, a sociedade compreenderia os escravos e até mesmo os outros animais”. ARISTÓTELES. A Política. Trad. Roberto Leal Ferreira. São Paulo: Martins Fontes, 2006. p. 53. Observa-se, na última parte da citação acima, que a noção de indivíduo dotado de um cabedal completo de direitos e deveres, para os gregos, resumia-se aos cidadãos, ou seja, aqueles que podiam participar da vida política.

77 “Assim, de inesgotável valor é que se perceba que o político e o ético se misturam. Isso porque, de acordo com a teologia aristotélica, a análise das noções do bem, entendido em sua faceta individual como 'bem singular', e em sua faceta coletiva como 'bem comum', está a apontar para uma unidade de princípios . À Ciência Maior, à Política, de reger os ditames arquitetônicos da vida em comum, de modo que leis, regras, diretrizes, normas, prescrições, valores, administração e pedagogia convirjam para a excelência (kalokagatía) do todo. Isso porque, para Aristóteles, a felicidade de um indivíduo depende do 'bem coletivo"'. BITTAR, Eduardo C. B. Curso de ética jurídica: ética geral e profissional. $4^{\mathrm{a}}$ ed. rev. São Paulo: Saraiva, 2007. p. 198. 
em Platão ${ }^{78}$, não são elas tratadas com razões distintas. Todavia, percebe-se, sobretudo no primeiro, uma diferenciação entre a justiça natural e aquela acordada entre os homens para o desenvolvimento de suas relações ${ }^{79}$, desenhando-se um esboço do que viria a concretizar, muito tempo depois, a efetiva separação entre Direito e Moral.

Não se pode olvidar o caráter sistemático e universalista do Direito Romano, destinado a uma aplicação geral a todo o vasto território do império (na verdade, convivia, em algumas áreas e situações específicas, com os direitos locais). Nos primeiros anos, como sabido, foi o Direito marcado por uma profunda sacralização das formas, algo que foi posteriormente modificado, acompanhando o espírito eminentemente prático dos romanos, representando, igualmente, uma atenuação da forte ligação que ainda iria subsistir, por um grande período de tempo, entre os preceitos éticos do Direito e aqueles advindos da Religião e da Moral.

Da alta para a baixa Idade Média, pode ser observado um movimento de intensificação do comércio e de aproximação entre os povos, perdido, de certa forma, no período anterior. As universidades são criadas e a Igreja encontra-se dotada de amplo poder e influência. Esses fatores irão ocasionar uma efervescência cultural cada vez mais forte, que se refletirá nos estudos científicos, inclusive no âmbito da ética, impulsionada pelas concepções dos teólogos cristãos acerca da natureza volitiva do pecado e, portanto, da

78 “A questão, o que é a Justiça? É originariamente colocada como a simples requisição de um conceito, mas se torna uma tentativa de caracterizar tanto uma virtude que pode se manifestar nas vidas privadas e uma forma de vida política, na qual o homem virtuoso estará em casa, na medida em que sempre eles podem estar em casa em um mundo de mudança e de irrealidade. Ambos já foram descritos no curso da explanação dos argumentos da República; o que resta é enfatizar a sua ligação interna. Na realidade, a moralidade e a política de Platão são bastante interdependentes. Cada qual necessita ser completada pela outra. (The question, What is justice? Is originally put as a simple request for a definition; but it becomes an attempt to characterize both a virtue which can be manifested in individual lives and a form of political life in which virtuous men will be at home, insofar as they can ever be at home in the world of change and of unreality. Both have already been described in the course of outlining the arguments of the Republic; what remains is to stress their internal connection. For in fact Plato's morals and Plato's politics are closely interdependent. Each logically requires to be completed by the other"). MACINTYRE, Alasdair. $A$ Short History of Ethics. $2^{\mathrm{a}}$ ed. reimp. Oxon: Routledge, 2005. p. 49.

79 "Revela-se, portanto, na cultura grega, mesmo antes dos sofistas, uma distinção clara entre o justo por natureza e o justo por convenção ou por lei. Esta doutrina, esclarecida por Platão, é depois desenvolvida de maneira exaustiva por Aristóteles, em cuja obra já encontramos os dados essenciais da problemática que ora nos preocupa. $\mathrm{O}$ estagirita reconhece que existe o justo por lei e o justo por natureza, afirmando que este tem por toda a parte a mesma força, por não depender das opiniões e dos decretos dos homem, expressão que é da natureza racional do homem. A lei é a inteligência menos a paixão, ou seja, depurada de todas as inclinações capazes de lançar um homem contra outro homem, esquecidos das exigências racionais, ambiciosos de mando e ávidos de bens". REALE, Miguel. ob. cit. p. 623. 
responsabilidade pessoal pelos atos praticados ${ }^{80}$.

Em São Tomás de Aquino, ganha relevo a ideia anteriormente construída pelos gregos, acerca da existência de um Direito Natural, como fruto da participação do homem na "lex aeterna", de todo modo condicionante da "lex humana", quer porque derivada daquela por dedução, quer porque representativa de uma escolha racional efetuada pelo homem segundo critérios de conveniência e oportunidade quando mais de um caminho se compatibiliza, no caso concreto, com os preceitos advindos do Direito natural ${ }^{81}$.

Observa-se, de acordo com tais assertivas, uma ainda não clara diferenciação entre os âmbitos do Direito, da Moral e da Religião, ainda que quanto a esta última já se vislumbre uma certa liberdade do chamado direito positivo no tocante a determinados casos concretos em que as possibilidades de escolha, como visto, sejam múltiplas.

Com a reforma protestante e a concepção de Lutero sobre a predestinação, que retira do ser humano qualquer liberdade frente à salvação, busca-se afastar o poder da Igreja sobre as pessoas na medida em que é desenvolvida a ideia de que o caminho ao paraíso independe da intercessão dela, antes tida como necessária. O movimento protestante, além disso, traz em seu bojo uma considerável complacência com a desigualdade política, no caso do poder temporal que se torna incontrastável, e a aversão à insubordinação a este, justificando sobremaneira o absolutismo despótico ${ }^{82}$.

Percebe-se com este movimento, a quebra da identidade antes existente entre Direito, Moral e Religião, tendo em vista que a realidade terrena não estaria mais condicionada pelas boas ações necessárias à salvação e mesmo pelo poder da Igreja, representando mundos totalmente diversos o da sociedade e da política, de um lado, e o da religião, de outro. Maquiavel representa bem tal modificação, pois busca estabelecer as bases e instrumentos necessários para a manutenção do Poder e da subordinação das pessoas a este, no sentido da preservação, a qualquer custo, da ordem ${ }^{83}$. O progressivo e contraditório desenvolvimento das noções de Direito natural e Direito positivo, já anteriormente esboçado, iria reforçar, nos anos vindouros, o fenômeno da cisão acima tratada.

${ }^{80}$ COMPARATO. Fábio Konder. ob. cit. p. 130.

81 REALE, Miguel. ob. cit. pp. 639-640.

82 MCINTYRE, Alasdair. ob. cit. p. 117.

83 Cf. MAQUIAVEL, Nicolau. O Príncipe e Escritos Politicos. Série “Os Pensadores". São Paulo: Ed. Nova Cultural, 1991. 
Adicionalmente, convém lembrar Jean Bodin e Thomas Hobbes ${ }^{84}$, os quais modificam o fundamento ético heterônomo do agir, que antes se encontrava em Deus, para o soberano, cuja tarefa é manter a paz e a ordem terrena ${ }^{85}$. Entende-se que não há um questionamento ético sobre o valor das ações do soberano, sendo justas as normas instituídas por ele, independente do conteúdo, na medida em que sejam fruto do acordo prévio de vontades entre todas as pessoas que se submetem ao seu Poder.

Essa quebra de identidade acarretou profundas implicações éticas nos séculos seguintes, como se observa claramente nas tentativas racionalistas de revelar, de maneira mais clara, as áreas específicas de domínio do Direito, da Moral e da Religião.

Deve-se ressalvar, todavia, que a concepção acerca do poder absoluto e inquestionável do soberano encontrou vozes dissonantes, que procuraram estabelecer, em razão da natureza do homem, fundamentos e limites éticos diferenciados.

Para John Locke, existem três tipos de Leis: a divina, a civil e a de opinião ou de reputação ${ }^{86}$. A primeira obviamente é aquela cujo autor é o próprio Deus. A segunda emana não de uma autoridade superior, mas da própria comunidade, conforme os homens livres, iguais e independentes, que apenas se submetem ao poder político de outrem mediante o seu consentimento, devendo o corpo político ser orientado, em suas ações, pela vontade da maioria, por ser impossível o acordo de todos, em constante renovação da concordância. Os homens, nessa submissão, não perdem o direito sobre aquilo que seja inerente a sua natureza humana, ou seja a vida, a liberdade e as suas posses que, portanto, devem ser respeitadas pela maioria soberana. Em tal fato nota-se um esboço importante do que viria a ser o entendimento acerca dos direitos humanos. A terceira lei, a de reputação ou opinião, diz respeito àquilo que é tido como bom ou mau no contexto social, variando de lugar para lugar, de tempo para tempo ${ }^{87}$.

Em Jean-Jacques Rousseau, desenvolve-se o argumento de que o progresso técnico e científico tende a aprofundar o processo de corrupção do homem, bom por natureza, à proporção em que torna os interesses individuais irrefreáveis e superiores aos

84 Cf. Leviatã, ou, Matéria, forma e poder de um estado eclesiástico e civil. Org. Richard Tuck; ed. bras. superv. por Eunice Ostrenky; trad. por João Paulo Monteiro e Maria Beatriz Nizza da Silva; trad. do aparelho crítico por Cláudia Berliner; rev. da trad. Eunice Ostrenky. 2a ed, São Paulo: Martins Fontes, 2008 .

85 COMPARATO. Fábio Konder. ob. cit. pp. 185-186.

86 MCINTYRE, Alasdair. ob. cit. p. 155.

87 COMPARATO, Fábio Konder. ob. cit. pp. 208-209. 
interesses coletivos, além de estabelecer objetivos artificiais, necessários para a manutenção da expansão mercanti1 ${ }^{88}$. Essa tese, aliás, será retomada nos momentos atuais por alguns autores, ainda que a abordagem ocorra de maneira diversa, como será melhor analisado no terceiro capítulo.

O pensamento de Immanuel Kant representa uma mudança considerável acerca do que seja efetivamente uma conduta ética, já que, para o citado autor, o ser humano não deve porque é livre, como apregoado pela doutrina católica citada, e sim é autônomo porque deve, ou age moralmente ${ }^{89}$. O cumprimento do dever ético, independente de qualquer objetivo ou preocupação com suas consequências, é que dá sustentação à autonomia, diferenciando o homem dos demais seres vivos.

Nesse sentido, desenvolve-se a ideia de imperativos hipotéticos, os quais estabelecem um dever-ser em razão de uma finalidade a ser alcançada, própria do domínio da técnica, e outros, chamados categóricos, próprios do domínio ético, ou moral, que impõem um agir ao indivíduo desvinculado de quaisquer objetivos. Os imperativos categóricos valem por si mesmo, no sentido de que "devo portar-me sempre de modo que eu possa também querer que minha máxima se torne em lei universal" (grifo do autor) ${ }^{90}$.

Partindo dessas premissas, para Kant, o Direito não impõe a conformidade interior do agente com o agir determinado, mas tão somente a exterior, razão pela qual nem toda a norma jurídica traduzirá um imperativo categórico, só o sendo aquela que, a par de erigir um dever-ser em lei, transforma-o também em motivos do cumprimento dessa lei. A norma jurídica seria aquela cumprida pela possibilidade de coação, podendo ou não, como visto, transmudar-se em uma norma moral, de cunho categórico. Delineia-se, claramente, uma nítida separação entre a Moral e o Direito.

Além disso, Kant afirma que somente o ser humano pode se guiar pelas leis

88 ROUSSEAU, Jean-Jacques. "Discurso sobre a origem e os fundamentos da desigualdade entre os homens". In: MAFFETONE, Sebastiano; VECA, Salvatore (orgs). A idéia de justiça de Platão a Rawls. São Paulo: Martins Fontes: 2005. pp. 177-210. p. 185.

89 "Para Kant, como para Rousseau, ser autônomo não é mera questão de obstinação ou ser independente dos outros ou das convenções sociais; é ter o modo de auto-determinação que leva em conta o das outras pessoas como um status moral. Ser kantianamente autônomo é agir moralmente (For Kant, as for Rousseau, to be autonomous is no mere matter of willfulness or independence from others or from social conventions; it is to have the mode of self-control that takes account of others' like moral status. To be kantianly autonomous is to act morally)". O'NEILL, Onora. "Kantian ethics". In SINGER, Peter (ed.). A companion to ethics. MALDEN/OXFORD/CARLTON: Blackwell Publishing. pp. 175-185. p. 179.

90 KANT, Immanuel. Fundamentação da metafísica dos costumes. Trad. António Pinto de Carvalho. São Paulo: Companhia Editora Nacional. p. 62. 
estabelecidas por ele mesmo e se revela aquele como um fim em si mesmo. Portanto, é o único que possui dignidade, aquilo que vale por si, sem referência a outros parâmetros.

Kant assume uma posição deveras formal de dever, ligando-o meramente à razão, sem qualquer referência aos limites e condicionantes histórico-temporais-sociais-culturais. Tal ideia foi frontalmente refutada por G.W.F. Hegel, que aduz que o homem se desenvolve de maneira intermitente e progressiva na história, por meio de um processo dialético de superação das contradições em sínteses, advindas do espírito, da razão, sem desconsiderar a realidade na qual esta se insere ${ }^{91}$.

É comum na doutrina jurídica se repetir que em Kant se encontra, determinado de maneira definitiva, o princípio da dignidade da pessoa humana, sem que a análise do seu conceito de dignidade seja corretamente situada nos pensamentos gerais do autor ora analisado. Isso leva à repetição de errôneas constatações que vão se perpetuando como verdades absolutas. O conceito kantiano extremamente formal conduz a intrincados problemas argumentativos. Afinal, o resultado de uma ação tem ou não relevância para a análise de seu valor ou desvalor ético? A resposta a essa indagação será melhor elucidada no transcorrer do presente trabalho, mas já se adianta a discordância com tal premissa.

Com o positivismo jurídico, a discussão ética se afasta do Direito, na medida em que a análise acerca da juridicidade de uma norma independe de seu conteúdo, e se liga tão somente à regularidade formal dela dentro de um esquema pré-definido de competências estatais e à possibilidade de seu descumprimento gerar a imposição coativa, mediante a utilização até mesmo da força física, de modo centralizado e institucionalizado.

Há, no pensamento formulado por Hans Kelsen ${ }^{92}$, uma tentativa de separação entre o dever-ser e o ser, ainda que esta, em alguns momentos, não se mostre tão clara, como ocorre na formulação do conceito que legitimaria toda a ordem jurídica piramidal, qual seja o da norma fundamental, cuja natureza é de um fato pressuposto, e em outra assertiva formulada pelo autor citado, no sentido de que a validade objetiva, ou vigência, de uma norma depende do seu cumprimento em certa medida.

A sistematização desta concepção neutra, em termos éticos, do Direito, servirá,

91 Cf. Fenomenologia do Espírito. Trad. de Paulo Meneses, com a colab. de Karl Heinz Efken e José Nogueira Machado. $4^{\mathrm{a}}$ ed. Petrópolis, RJ: Vozes: Bragança Paulista: Editora Universitária São Francisco, 2007.

92 Cf. Teoria pura do Direito. Trad. João Baptista Machado. $8^{\mathrm{a}}$ ed., $2^{\mathrm{a}}$ tir. São Paulo: WMF Martins Fontes, 2011. 
como amplamente sabido, à justificação de inúmeros atentados cometidos contra o homem por atores políticos que não encontraram quaisquer limites à implementação de suas convicções mais absurdas e que suprimiam a individualidade verdadeiramente autônoma.

Nos regimes governados por tais atores políticos, chamados totalitários, a autonomia privada dos indivíduos desaparece, ao passo que o Estado controla todo o espectro de ação humana. Dessa forma, consolida-se uma total uniformização da população, que se torna uma massa amorfa, guiada pelas razões de Estado ou da autoridade que detém o poder político-institucional.

De todo modo, não é pertinente enfocar a conduta ética sob uma perspectiva meramente formal, baseada no imperativo cego da obediência ao dever, independente dos resultados obtidos, ou excluir da análise jurídica considerações sobre o valor da conduta. Necessário, também, como Hans Jonas, prestigiar a ética da responsabilidade ${ }^{93}$, ou seja, aquela que leva em conta os possíveis resultados, negativos ou positivos, de uma conduta, impondo ao ser humano condutas de acordo com os valores cuja proteção se mostre eticamente necessária, em consideração igualitária ao seu semelhante. Uma ação "a priori" boa pode redundar em algo maléfico, do ponto de vista do resultado axiológico, devendo ser, portanto, evitada.

Reconhecer cada ser humano como merecedor de respeitos mínimos a certos atributos que garantam a perpetuação de sua autonomia, somente limitada por razões que sirvam à proteção da autonomia dos demais indivíduos, é o cerne principal do fundamento ético da ação das pessoas.

É inegável, sob a perspectiva histórica, como analisado anteriormente, que o fundamento da ética possui uma patente mutabilidade, ora reconhecendo-se algo como absoluto, ora como relativo, ou ainda com viés religioso, técnico ou humano. Na verdade, essa variação de embasamento tem mais relação com a teorização influenciada por vetores culturais de cada época que propriamente com a essência em si mesma deste fundamento, revelada pouco a pouco no curso dos tempos. Este alicerce repousa, em última análise, no ser humano, abstratamente considerado, como único ente capaz de ter autoconsciência do papel que assume como personagem histórico de transformação e superação da realidade de acordo com os próprios interesses ${ }^{94}$, qualidade esta que lhe obriga a observar o devido

93 Esta ideia será melhor analisada no capítulo três do presente trabalho.

94 "Em matéria ética, o critério ou modelo de vida deve valer, no essencial, para todos os homens e todas as 
respeito a este mesmo atributo também titularizado pelas demais pessoas.

São evidentes também o diálogo e a influência recíproca exercida pelo Direito e a Moral, o que impossibilita afirmar a existência de dois âmbitos estanques, devendo-se falar, na realidade, em maior adequação de um ou de outro para a normatização de determinadas situações.

O Direito está baseado em uma ordem construída e dotada de coercibilidade organizada, a qual paira acima das pessoas e estabelece modos de conduta a serem obrigatoriamente observados, mas cuja legitimidade está submetida à proteção da autonomia e dignidade destas. Já a Moral encontra sua referência direta na outra pessoa e no próprio indivíduo, não em um sistema coercível, impositivo. A bioética e o biodireito retratam bem, como será visto, tais constatações.

É importante ressaltar que o Nazismo e a Segunda Guerra Mundial, que culminaram com a Declaração Universal dos Direitos do Homem, trouxeram um novo significado à questão ética da conduta dos indivíduos em geral, reforçando a existência de um fundamento precípuo, qual seja a dignidade da pessoa humana que, muitas vezes, por retratar um conceito deveras aberto e fluido, tende a ser utilizada de maneira equivocada na justificação de determinadas atitudes e opiniões. E é exatamente nos direitos humanos ou fundamentais que este princípio da dignidade da pessoa humana encontrará a devida elucidação e concretização.

\subsubsection{Dignidade da pessoa humana: conteúdo e limites}

No item anterior, apontou-se que o fundamento ético da conduta se encontra na qualidade do homem como ser capaz de se autodeterminar ${ }^{95}$, o que o dota de um valor intrínseco inexorável, não passível de contraste perante qualquer outro valor. Chamou-se tal alicerce de dignidade da pessoa humana.

Dessa forma, qualquer ordem jurídica, objeto cultural criado pelo homem para a

civilizações”. COMPARATO. Fábio Konder. ob. cit. p. 439.

95 "A natureza forma o conteúdo da vontade e a possibilidade de auto-realização. A pessoa humana é sempre um certo modo de realização livre da humanidade (animalidade, racionalidade, sociabilidade), por isso nós falamos em pessoa 'humana'. Se o ser humano fosse determinado por sua natureza, não falaríamos de pessoa. Mas se o seu agir fosse completamente livre da natureza humana, não poderíamos falar de pessoa 'humana'”. BARZOTTO, Luiz Fernando. "Pessoa e reconhecimento - uma análise estrutural da dignidade da pessoa humana". In: ALMEIDA FILHO, Agassiz; MELGARÉ, Plínio (orgs.). Dignidade da pessoa humana. Fundamentos e critérios interpretativos. São Paulo: Malheiros Editores, 2010, pp. 39-67. p. 49. 
proteção, na vida em sociedade, de seus atributos inerentes, necessários à garantia da autonomia e do desenvolvimento de suas potencialidades, não pode se afastar, para que se tenha como minimamente legítima, desse objetivo primeiro, dessa referência essencial e direta ao ser humano ${ }^{96}$. Isso não significa dizer que somente o homem, ou algo necessariamente referido a ele, seja considerado como valor a ser assegurado pela ordem jurídica.

Conforme visto, a concepção kantiana de dignidade é aquela mais disseminada entre os autores, no sentido de que somente o ser humano a possui, em virtude de sua racionalidade e consequente possibilidade de agir autonomamente ou dever algo. Digno é o homem na proporção em que é o fim de tudo, não podendo ser instrumentalizado ${ }^{97}$, de modo arbitrário e contra a sua vontade (e mesmo de acordo com esta no tocante a valores específicos), para o alcance de outros objetivos. Todavia, esse delineamento se mostra deveras antropocêntrico, desprezando o valor que outras realidades possuem e que exigem do Direito prestígio e tutela ${ }^{98}$.

Identifica-se que nem toda a proteção jurídica é lastreada no ser humano, bastando afirmar, exemplificativamente a vedação de crueldade contra os animais. Tal reconhecimento não impede que se afirme a especificidade da dignidade da pessoa humana

96 "A noção de direitos humanos implica que se trata de direitos atribuíveis a cada ser humano enquanto tal, que esses direitos são vinculados à qualidade de ser humano, não fazendo distinção entre eles e não se estendendo a mais além. Reconheça-se ou não a origem religiosa do lugar especial reservado aos seres humanos nessa doutrina, proclama ela que a pessoa possui uma dignidade que lhe é própria e merece respeito enquanto sujeito moral, livre, autônomo e responsável. Daí a situação ímpar que lhe é reconhecida e que o direito tem de proteger". PERELMAN, Chaïm. ob. cit. p. 400.

97 Não se nega o fato real, por exemplo, da prestação de serviços remunerados em que alguém se submete às ordens de outrem de modo instrumental, não significando isso, porém, uma coisificação atentatória à dignidade humana, mas simples forma de convivência social, aceito pelos indivíduos de um modo geral. O prestador de serviço troca a força de seu trabalho por uma certa remuneração destinada a sua manutenção econômica. Diferentemente ocorre no caso do trabalho escravo, ou análogo, em que mesmo a concordância do trabalhador não retira a sua ilicitude e ferimento da dignidade da pessoa humana.

98 "Com a boa vontade de seu tempo exclusivamente para com os seres humanos, o pensamento de Kant acaba por justificar a destruição da natureza. É verdade que, antes dele, Descartes sustentou a idéia (que já ouvi, ainda hoje, repetida por grandes médicos) que o animal é uma máquina. Ora, é preciso acabar com essa concepção de que a vida na natureza é algo axiologicamente vazio, algo neutro, bruto, que pode ser manipulado e, depois, pago em dinheiro, por nós, 'os dignos'. A vida é um valor. A vida é um valor em si, um valor ontológico. A permanente afirmação da dignidade da pessoa humana, sem valorização da vida em geral, é uma grande arrogância. No fundo, estão dizendo que o homem é o rei da criação. Cada um de nós, um reizinho. Vejo, em momentos de alucinação, a imensa procissão dos 'dignos', caminhando pelo universo, todos com o rei na barriga, encabeçado pelos 'grandes do mundo' e seguidos, depois, pela fila infindável dos bilhões de 'dignos' (dignos deserdados) do planeta Terra". AZEVEDO, Antônio Junqueira de. "Crítica ao personalismo ético da Constituição da República e do Código Civil". In: AZEVEDO, Antônio Junqueira de; TÔRRES, Heleno Taveira; CARBONE, Paolo; (coords.). Princípios do novo Código Civil Brasileiro e Outros Temas. Homenagem a Tullio Ascarelli. $2^{\mathrm{a}}$ ed. São Paulo: Quartier Latin, 2010. pp. 20-31. pp.21-22. 
em relação aos demais valores não referidos a esta e que mereçam atenção da ordem normativa, como mencionado. De certa forma, é a própria dignidade do ser humano que impõe o reconhecimento do valor intrínseco de outras realidades que o cercam, razão pela qual diferencia o homem dos demais seres.

$\mathrm{Na}$ realidade, independentemente de se considerar que seres não humanos possuem ou não dignidade, o reconhecimento desta qualidade ao ser humano, baseada na autonomia e inerente responsabilidade pelos atos praticados, não o eleva a um patamar superior, contudo, impõe a observância de certos deveres para com outros seres e os mecanismos aptos a garantir a sua obrigatoriedade ${ }^{99}$.

O fato de o homem representar, de maneira abstrata, o único ser com possibilidade de construir a sua própria história, em que domina as condicionalidades naturais e possui a consciência de si mesmo como ator desse processo perene, fundamenta a exigência de uma proteção especial da pessoa. Ora, se a Filosofia, as Ciências, a Ordem jurídica são criações do espírito humano independente de uma qualquer discriminação social prévia, com o objetivo de aprimorar a vivência das pessoas, inegável que essas mesmos produtos devam manter em seu bojo, de forma contínua e inexorável, a mesma finalidade.

Há um movimento circular contínuo na medida em que criador e criação se ligam de maneira umbilical. Tal fato justifica a formulação de um conceito que, reconhecendo as qualidades inerentes daquele criador responsável pelo nascimento das criaturas, permita que essas não se desviem daquele, o que possibilita a reprodução constante desse processo de criação. Tolher essa faculdade do homem representa um atentado à dignidade da pessoa humana. Esse é o fundamento.

Apesar da referência ao ser humano abstratamente considerado ser necessária para a fixação exata dos elementos que permitam reconhecer qual ser é dotado de dignidade especial, a realização desse princípio se dá no âmbito concreto da individualidade, não sendo correta uma tal argumentação que procure sacrificar certos direitos mínimos individuais sob o argumento de proteção da pessoa humana como ente abstratamente considerado $^{100}$.

99 SARLET, Ingo Wolfgang. Dignidade da pessoa humana e direitos fundamentais na Constituição Federal de 1988. $8^{\mathrm{a}}$ ed., Porto Alegre: Livraria do Advogado Ed., 2010. pp. 39-41..

100 "Como ser em si, o ser humano é um todo, e não uma parte de um grupo, nação ou Estado: isto é, não pode ser sacrificado em nome do todo ou da maioria, como no utilitarismo. Como um ser com outrem, a pessoa traz consigo a exigência de reciprocidade. Como um ser para si, o ser humano é autofinalizado, 
Deve ser ressaltado, de acordo com o dito anteriormente, que a dignidade da pessoa humana não se restringe a um fator meramente biológico, entretanto, revela-se no curso do processo histórico e na vivência social experimentada por todos os seres humanos ${ }^{101}$. Ressalva-se que esse fato não significa aceitar certas práticas passadas como aceitáveis somente por estarem concordes com as concepções vigentes. Reconhecer a dignidade da pessoa humana de acordo com um critério biológico e cultural coincide em afirmar que só é possível tratar desta no contexto do reconhecimento do homem como ser social e superador da natureza. Trata-se de uma formulação apenas revelada, um ato de fé, pode-se dizer, não passível de qualquer rechaço ou predicação ${ }^{102}$.

Não há como submeter a pessoa humana a uma análise científica e instrumental, pois não se trata de algo evidente, adequado a certas constantes universais. A pessoa humana é na medida em que reconhecida pelo outrem como ser humano e em que reconhece a si e ao outro como homem ${ }^{103}$.

Apesar de o fundamento da dignidade da pessoa humana ser bastante claro, ao menos de acordo com o enquadramento acima efetuado de certo modo considerado majoritário, existe uma patente dificuldade em se definir precisamente e de maneira geral o conteúdo de tal princípio que encontre certo consenso doutrinário.

Evidente que formulações fracas não causam grandes querelas, mas tampouco definem de maneira satisfatória o conceito em tela. Esse tipo de abordagem, em realidade, reflete mais o fundamento da dignidade que propriamente a sua substância conceitual.

Além disso, pode-se questionar a utilidade acerca da definição do conteúdo da dignidade da pessoa humana, na proporção em que seja possível verificar, em vários casos, aquilo que efetivamente a contrarie, sendo isto suficiente para o Direito e a tutela conferida.

não podendo ser transformado em meio para fins externos a si, na expressão de Kant. Considerar o ser humano como pessoa é o que será denominado reconhecimento". BARZOTTO, Luiz Fernando. ob. cit. p. 50.

101 SARLET. Ingo Wolfgang. ob. cit. p. 54.

102 "A dignidade da pessoa humana, o valor de cada ser humano como pessoa, é matéria de constatação, e não de argumentação. Por isso, não há como ponderá-la com quaisquer princípios, regras, conveniências etc. $\mathrm{O}$ fundamento não pode ser ponderado com o fundamentado, o absoluto com o relativo. Reconhecer o ser humano como pessoa, em termos éticos, significa assumi-la como um absoluto, como transcendente à deliberação e à fundamentação". BARZOTTO. Luiz Fernando. ob. cit. p. 60.

103 MELGARÉ, Plínio. "Notas sobre a repersonalização do direito civil". In ALMEIDA FILHO, Agassiz; MELGARÉ, Plínio (orgs.). Dignidade da pessoa humana. Fundamentos e critérios interpretativos, São Paulo: Malheiros Editores, 2010, pp. 150-163. p. 158. 
Todavia, não se nega existência de situações limítrofes em que não é possível estabelecer, de antemão, uma clara separação entre o digno e o indigno, o que torna necessária a análise concreta para o estabelecimento da proteção jurídica, devendo uma prévia concepção da dignidade servir como alicerce mínimo de justificação de um sentido porventura escolhido.

Ainda assim, não se nega que mesmo nesse contexto certas situações somente poderão ser solucionadas de acordo com critérios não abstratamente estabelecidos, demandando o recurso à razoabilidade e proporcionalidade, analisadas no cap[itulo 3 do presente.

O grande problema reside no fato de a dignidade da pessoa humana ser utilizada como solucionadora de todos os problemas, sem preocupação com a formulação de um conteúdo mínimo além daquele tautológico referido, que leva em conta somente o seu fundamento, o que acaba por esvaziar sua utilidade como critério suprapositivo de resolução de conflitos.

Há de se recuperar a dignidade da dignidade como fator científico-hermenêutico, deixando a invocação a ela como última "ratio" naqueles casos em que outras regras, ou mesmo princípios jurídicos, não possam oferecer uma resposta adequada aos eventuais conflitos existentes.

Ingo Wolfgang Sarlet preceitua a dignidade da pessoa humana como:

a qualidade intrínseca e distintiva reconhecida em cada ser humano que o faz merecedor do mesmo respeito e consideração por parte do Estado e da comunidade, implicando, neste sentido, um complexo de direitos e deveres fundamentais que assegurem a pessoa tanto contra todo e qualquer ato de cunho degradante e desumano, como venham a the garantir as condições existenciais minimas para uma vida saudável, além de propiciar e promover sua participação ativa e co-responsável nos destinos da própria existência e da vida em comunhão com os demais seres humanos, mediante o devido respeito aos demais seres que integram a rede da vida ${ }^{104}$ [grifo do autor].

Em que pese a amplitude dessa formulação, a parte final representa aquilo defendido pelo presente trabalho, no sentido de que a dignidade da pessoa humana consiste em elaborar o aparato instrumental necessário à preservação da vida e, de maneira central,

104 Ob. cit. p. 70. 
da autonomia do ser humano ${ }^{105}$, desde que compatível com as dos demais.

Observa-se, adicionalmente, que a dignidade da pessoa humana caracteriza-se como inegável pauta axiológica bioética. O aspecto central de qualquer discussão que envolva os avanços tecnológicos e sua aplicação aos seres humanos é, sem dúvida, a busca de parâmetros e limites que permitam o melhor aproveitamento de tal desenvolvimento científico com o mínimo sacrifício dos direitos fundamentais das pessoas.

O relativismo não é a melhor saída no contexto de um mundo tão culturalmente fragmentado e cada vez mais sob o império da técnica em detrimento da ética, a fim de que se evite a perpetuação, de acordo com bandeiras meramente utilitaristas ${ }^{106}$, de agressões ao ser humano, à vida, à integridade física e, acima de tudo, à liberdade ${ }^{107}$, qualidade esta que o diferencia dos demais seres vivos e que justifica, como mencionado, a sociedade e, consequentemente, o próprio Direito.

Tal tarefa, além de ser bastante dificultosa, não concede um conceito hermético, acabado, imutável e sem dificuldades práticas de aplicação no caso concreto, ainda mais quando envolvidos, conflituosamente, direitos fundamentais com base direta ou indireta no princípio da dignidade da pessoa humana. O que se busca, desse modo, é tornar mais seguro e legítimo o processo argumentativo que leva à tomada de certas decisões.

105 "Os direitos humanos referem-se menos à forma que as pessoas 'são', do que sobre o quê elas poderiam se tornar. Eles tratam da moral, ao invés de tratarem da concepção natural ou jurídica de pessoa". (Human rights are less about the way people 'are' than about what they might become. They are about moral rather than natural or juridical persons)". DONNELY, Jack. Universal human rights in theory and practice. $2^{\mathrm{a}}$ ed. Ithaca: Cornell University Press, 2003. p. 15.

106 “Assim, ainda que se possa reconhecer a possibilidade de alguma relativização da dignidade pessoal e, nesta linha, até mesmo de eventuais restrições, não há como transigir no que diz com a preservação de um elemento nuclear intangível da dignidade, que justamente - e aqui poder-se-á adotar a conhecida fórmula de inspiração kantiana - consiste na vedação de qualquer conduta que importe em coisificação e instrumentalização do ser humano (que é fim, e não meio). Da mesma forma, vale lembrar que com isto não se está a sustentar a inviabilidade de impor certas restrições aos direitos fundamentais, ainda que diretamente fundadas na proteção da dignidade da pessoa humana, desde que, à evidência, reste intacto o núcleo em dignidade destes direitos". SARLET. Ingo Wolfgang. ob. cit. p. 59.

$107 \mathrm{O}$ princípio ético da dignidade da pessoa humana garante os básicos direitos à vida e à integridade, bem como o direito à auto-determinação, com a necessidade de obtenção de consentimento do indivíduo afetado, para todas as intervenções realizadas por terceiros. $\mathrm{Na}$ área médica, a auto-determinação dos pacientes é intensivamente discutida no que concerne ao 'consentimento informado' como pré-requisito a todas as atividades médicas, influenciando todas as decisões em medicina e pesquisa. (The ethical-legal principle of human dignity guarantees the basic rights of life and integrity as well as the right of selfdetermination, with the necessity of consent for all interventions of third persons. In the medical area the self-determination of patients is intensively discussed as the problem of 'informed consent' as a prerequisite for all medical activities, influencing all decisions in medicine and research)". SIMON, Jürgen. "Human dignity as a regulative instrument for human genome research". In: MAZZONI, Cosimo Marco (ed.). Ethics and law in biological research. The Hague/London/New York: Martinus Nijhoff Publishers/Kluwer Law International, 2002. pp. 35-45. p. 41. 


\subsubsection{Direitos humanos e fundamentais}

Fábio Konder Comparato leciona que a partir da Idade Média é que se moldou a concepção de pessoa que originou os chamados direitos humanos. Tal concepção tinha como conteúdo uma ideia de substância, espiritual e corporal própria dos seres humanos, que os identifica em relação aos demais seres vivos ${ }^{108}$.

Como visto, na Idade Moderna, com o advento do estado absolutista e perda de força do cristianismo, já se percebe uma cisão efetiva entre a moral dos homens e a dos príncipes, entre moral e direito, sendo manejadas as diretrizes éticas de acordo com os interesses prevalecentes em um certo Estado. Isso nega universalidade a qualquer princípio ético e, consequentemente, subjuga os indivíduos aos poderes quase ilimitados titularizados pelo soberano.

Ainda nessa fase, entretanto, não se pode esquecer a existência de alguns movimentos pontuais que procuraram atenuar este poder absoluto, estabelecendo determinados direitos mínimos aos cidadãos, como aqueles verificados na Inglaterra e que culminaram na proclamação da Magna Carta, do "Bill of Rights Act", do "Habeas Corpus Act", dentre outros ${ }^{109}$.

Com a Revolução Francesa e a Independência dos Estados Unidos ${ }^{110}$, restaura-se o desejo de universalização do respeito imprescindível ao homem como ser autônomo e

108 Ob. cit. p. 457.

109 'Não obstante e existência de antecedentes tão remotos como os 'fueros' espanhóis, as cartas inglesas, as declarações norte-americanas, etc., é com a Declaração dos direitos do homem e do cidadão de 1798, que se explicitou que a mera vontade dos mais fortes não é uma justificativa última das ações que comprometem interesses vitais dos indivíduos, e que a qualidade de ser humano por si constitui um título suficiente para alguém gozar de certos bens que são indispensáveis para que cada um eleja seu próprio destino com independência do arbítrio dos demais. (No obstante antecedentes tan remotos como los fueros españoles, las cartas inglesas, las declaraciones norteamericanas, etc., es con la Declaración de los derechos del hombre y del ciudadano de 1789, que se hace completamente explícito que la mera voluntad de los fuertes no es una justificación última de acciones que comprometen intereses vitales de los individuos, y que la sola cualidad de ser un hombre constituye un título suficiente para gozar de ciertos bienes que son indispensables para que cada uno elija su proprio destino con independencia del arbitrio de otros)". NINO, Carlos Santiago. Ética y derechos humanos. Un ensayo de fundamentación. $2^{\mathrm{a}}$ ed., $2^{\mathrm{a}}$ reimp.,Buenos Aires: Editorial Astrea, 2007. p. 2.

110 “'[O] artigo I da Declaração que 'o bom povo da Virgínia' tornou pública, em 12 de junho de 1776, constitui o registro de nascimento dos direitos humanos na história. É o reconhecimento solene de que todos os homens são igualmente vocacionados, pela sua própria natureza, ao aperfeiçoamento constante de si mesmos. A 'busca da felicidade', repetida na Declaração de Independência dos Estados Unidos, duas semanas após, é a razão de ser desses direitos inerentes à própria condição humana. Uma razão de ser imediatamente aceitável por todos os povos, em todas as épocas e civilizações. Uma razão universal, como a própria pessoa humana". COMPARATO. Fábio Konder. A afirmação histórica dos direitos humanos. $2^{\mathrm{a}}$ ed. São Paulo: Saraiva, 2001. pp. 47-48. 
portador de direitos intrínsecos, ainda que sob razões, de certa forma, utilitárias ao capitalismo industrial em nascimento, o que se demonstra nos ideários da igualdade, liberdade e fraternidade, embasadores da elaboração de uma concepção sistemática dos direitos humanos ${ }^{111}$.

Observa-se, porém, que o movimento possui contradições internas, já que, ao mesmo tempo, valoriza de modo excessivo a individualidade e a igualdade meramente formal entre os indivíduos. Isso redundou em abruptas fraturas no decorrer do processo histórico, como no caso do neocolonialismo, dos totalitarismos e das duas grandes guerras. Ainda hoje, a par da existência da Declaração Universal dos Direitos do Homem da Organização das Nações Unidas, existe uma não desprezível contenda acerca do caráter universal ou relativo dos direitos humanos.

Nesse contexto, podem ser identificadas três fases no que tange ao reconhecimento dos direitos humanos: a primeira, basicamente filosófica, tendente ao universalismo, ao ser referida ao homem abstratamente considerado, porém não positiva, que proclama algo que deveria ser buscado; a segunda, ocorrida com as primeiras declarações jurídicas (Americana e Francesa), reconhece a existência de certos direitos dos indivíduos frente ao Estado do qual sejam nacionais, atestando aquele ente, portanto, não como fim em si mesmo, mas como meio de vida das pessoas. Percebe-se nessa concepção a positividade ou concretude desses direitos e a não universalidade real, não obstante a Declaração dos Direitos do Homem e do Cidadão estabelecer como um dever-ser, a exemplo do que proclamado filosoficamente, o objetivo de asseguração a todos os homens daqueles direitos efetivamente conferidos aos nacionais; e uma terceira, iniciada com a Declaração Universal dos Direitos do Homem, universal e positiva, ainda que dependente da construção de um sistema para a sua garantia, obtida pelo consenso entre a maioria dos homens através de seus Estados de origem e sistematizada como um efetivo objetivo vinculante a esses Estados ${ }^{112}$.

Sem dúvida alguma que os chamados direitos humanos, ou fundamentais, visam a

111 “O individualismo, e a doutrina dos direitos humanos que é sua expressão mais contundente, é uma concepção burguesa que, ganhando forma no Renascimento, impôs-se à consciência ocidental no século XVII e sobretudo no século XVIII. Anteriormente e durante séculos, as autoridades religiosas e políticas, em geral confundidas, quase não toleravam oposição. Apenas os detentores do poder conheciam a verdade e nem se podia pensar em conceder ao indivíduo um direito à autonomia, à liberdade de pensamento e de expressão". PERELMAN, Chaïm. ob. cit. p. 406.

112 BOBBIO, Norberto. A era dos direitos. Trad. Carlos Nelson Coutinho. Rio de Janeiro: Campus, 1992. pp. 28-30. 
concretizar o fundamento ético de conduta em sociedade, consubstanciado no respeito à pessoa humana, imputando certos atributos e consequentes prerrogativas a todos os seres humanos de modo inexorável e intangível. São direitos morais que independem de reconhecimento positivo para serem alegados, ainda que tal positivação tenha uma importância prática inegável ${ }^{113}$.

São direitos intrínsecos, inalienáveis e universais, titularizados por todo e qualquer ser humano, independente de sua condição política, social, jurídica ou econômica. $^{114}$.

Ressalva-se que há situações em que certos direitos são próprios de um grupo determinado, composto por indivíduos dotados de qualidades tais que justifiquem um tratamento diferenciado e mais protetivo, como no caso das crianças, ou dos idosos. A universalidade, nesse caso, refere-se ao fato de que qualquer pessoa que venha a possuir aquelas características atinentes ao grupo em questão será titular dos respectivos direitos. Afinal, uma proteção diferenciada apenas significa a especificação de direitos já tidos como humanos ou fundamentais ${ }^{115}$.

A questão de se efetuar a diferenciação terminológica entre direitos humanos e direitos fundamentais possui diversas vertentes em sede doutrinária. Há quem reconheça não haver diversidade efetiva entre os $\operatorname{conceitos}^{116}$, compreendendo outros que tratam de objetos diferentes. E, mesmo entre os que realizam a diferenciação, há certo dissenso quanto aos critérios.

Entende-se que o melhor fator de distinção seja tratar os direitos humanos como

113 NINO, Carlos Santiago. ob. cit. pp. 24-25.

114 DONNELY, Jack. ob. cit. p. 10.

115 NINO. Carlos Santiago. ob. cit. p. 42.

116 "Há quem separe direitos humanos de direitos fundamentais. Mas os direitos humanos e os direitos fundamentais não constituem dois institutos jurídicos distintos. Essa separação retira humanidade ao fundamental e fundamentalidade ao humano. Ademais, contra isso se opõem a teoria e a prática dos direitos humanos, os quais constituem um todo dialético, formado de direitos mais gerais (direitos estruturais) que interagem com direitos mais particulares (direitos conjunturais). Assim, no todo dialético dos direitos humanos, o fundamental e o operacional se apóiam e se influenciam reciprocamente, sem ficar separados um do outro. Dessa maneira, conjugando-se entre si, os direitos humanos fundamentais e os operacionais colocam em ação um só e mesmo instituto jurídico para atender a uma só e mesma finalidade: realizar toda a essência humana em toda a existência humana, ou seja, realizar o ser humano em todos os indivíduos humanos, nas condições de dignidade condizentes com cada época da história da civilização. Em verdade, não só realizar, mas também garantir a humanidade que tem sido realizada ao longo de sua história". BARROS, Sérgio Resende de. "Direitos humanos da família: dos fundamentais aos operacionais". In: PEREIRA, Rodrigo da Cunha (coord.). Afeto, Ética, Família e o novo Código Civil. Belo Horizonte: Del Rey, 2004. pp. 606-620. p. 609. 
aqueles reconhecidos na esfera internacional ${ }^{117}$, independente de sua positivação nas ordens jurídicas dos Estados soberanos, ao passo que os fundamentais seriam aqueles direitos, humanos ou não, que encontrem guarida primordial nos sistemas jurídicos internos $^{118}$. A diferença se dá em relação à base formal de cada conjunto de direitos mencionado, tendo em vista que o alicerce material de ambos se encontra no próprio ser humano.

Não há dúvidas de que a maioria dos direitos fundamentais acaba, quanto ao conteúdo, coincidindo com os ditos direitos humanos, entretanto, a ocorrência desse fato não é necessária, porque muitas vezes acontece de o catálogo de direitos fundamentais de um determinado Estado ser menor (mais frequente) ou maior do que aquele contido nos documentos jurídicos internacionais ${ }^{119}$.

A adoção da distinção acima efetuada não impede que se reconheça o caráter universal dos direitos humanos, em virtude de, ainda que não reconhecidos por uma determinada ordem interna, servirem como efetivo instrumento de pressão a própria internalização, bem como de intervenção no caso de sua violação ${ }^{120}$.

$\mathrm{Na}$ realidade, nenhum Estado ignora a existência dos direitos humanos, havendo certa diversidade formal quanto à extensão do catálogo positivado, ou mesmo sua implementação e interpretação. O certo é que os direitos humanos são uma realidade nas ordens internas e internacionais, ainda que o efetivo respeito a esses não seja concretamente verificado de maneira desejável. Mesmo países que possuem sérias deficiências no tratamento desses direitos não os desprezam, ainda que formalmente apenas, nas suas constituições político-jurídicas, utilizando-os, muitas vezes, até como justificativa de ações que, na verdade, colocam-nos em vulnerabilidade ${ }^{121}$.

117 Incluem-se nesta categoria, também, aqueles direitos não positivados internacionalmente, mas que podem ser considerados existentes pela sua referibilidade direta ao ser humano em sua condição autônoma essencial. Todavia, atualmente, difícil encontrar direitos humanos que não tenham sido carreados, ao menos indiretamente, pelos documentos jurídicos internacionais.

118 SARLET, Ingo Wolfgang. A eficácia dos direitos fundamentais. 9a ed., Porto Alegre: Livraria do Advogado Ed., 2008. p. 36.

119 Idem. p. 39.

120 "É irrecusável, por conseguinte, encontrar um fundamento para a vigência dos direitos humanos além da organização estatal. Esse fundamento, em última instância, só pode ser a consciência ética coletiva, a convicção, longa e largamente estabelecida na comunidade, de que a dignidade da condição humana exige o respeito a certos bens ou valores em qualquer circunstância, ainda que não reconhecidos no ordenamento estatal, ou em documentos normativos internacionais”. COMPARATO. Fábio Konder. $A$ afirmação histórica dos direitos humanos. p. 57.

121 "A necessidade de parecer estar agindo em nome dos direitos humanos, porém, diz muito sobre os valores 
Importante definir, em caráter geral, de que tratam, mais especificamente, estes chamados direitos humanos, ou fundamentais, conforme a perspectiva em que se visualize o fenômeno.

O conceito bastante difundido de gerações ou dimensões dos direitos humanos ou fundamentais busca agrupar os diferentes direitos de acordo com certas características semelhantes quanto ao conteúdo, bem como ao momento histórico em que foram introduzidos e consolidados nas ordens jurídicas internacionais e internas.

Trata-se de uma abordagem apenas conceitual com a finalidade de facilitar a compreensão do campo ora estudado, mas que não retrata a real dinamicidade existente no intermitente processo histórico de construção, afirmação e reafirmação dos direitos humanos e fundamentais.

Não se deve perder de vista que tais direitos nascem, extinguem-se, modificam-se, fortalecem-se e enfraquecem-se de acordo com as contingências existenciais experimentadas pelo homem no curso da vida em sociedade. Caracteriza-se como um processo com avanços e retrocessos, bastante acoplado aos campos jurídico e político.

Ainda que o termo geração seja utilizado, não se pode perder de vista que as diferentes gerações não são excludentes, fazendo parte de um cenário contínuo de nascimentos de novos direitos (e gerações) e acumulação com os já existentes. As diferentes gerações não são estanques entre si, possuindo, em realidade, uma inegável complementaridade no sentido da tutela efetiva do ser humano frente às diversas ordens políticas e aos demais homens.

Mais comumente se fala em direitos de primeira, segunda e terceira geração, existindo quem hoje afirme a presença daqueles quarta, quinta e até sexta geração.

Os chamados direitos de primeira geração são aqueles originados do pensamento liberal-burguês do século XVIII, de marcado cunho individualista. São precipuamente os direitos civis e políticos como o direito à vida, à liberdade, à igualdade formal perante à Lei, à propriedade, os direitos processuais e os de voto.

Já os direitos da segunda geração são uma resposta aos efeitos deletérios advindos do processo de industrialização, bem como da Primeira Guerra Mundial, criando massas de

e aspirações dominantes. Mesmo usos cínicos rendem tributo à exigência moral de comprometimento com os direitos humanos. (The need to appear to be acting on behalf of human rights, however, tells us much about dominant values and aspirations). Even cynical uses pay tribute to the moral imperative of a commitment to human rights". DONNELY, Jack. ob. cit. p. 39. 
excluídos sem acesso a um mínimo para a sobrevivência digna. São frutos diretos da doutrina comunista, inseridos, originariamente, nas Constituições do México, de 1917, e de Weimar, de 1919. Observa-se que o reconhecimento desses direitos teve guarida até mesmo nos Estados Unidos da América, de espírito deveras liberal, em razão da depressão de 1929 e implantação, entre os anos de 1933 e 1937, da política de estímulo à atividade econômica, por Franklin Delano Roosevelt, denominada "New Deal”, fenômeno retomado (ao menos de modo tentado, por ora) na atual administração do democrata Barack Obama $^{122}$. Busca-se com o reconhecimento desses direitos amenizar as profundas desigualdades sociais produzidas, impondo certos deveres positivos ao Estado de realizar prestações positivas no sentido de implementação do bem-estar social, sem esquecer que se referem também aos direitos dos trabalhadores.

Por fim, os direitos de terceira geração são aqueles de titularidade coletiva ou difusa nascidos para fazer frente a novas situações problemáticas "geradas, dentre outros fatores, pelo impacto tecnológico, pelo estado crônico de beligerância, bem como pelo processo de descolonização do segundo pós-guerra e suas contundentes consequências, o que acarreta profundos reflexos na esfera dos direitos fundamentais ${ }^{123}$. Como exemplo mais claro dessa geração está o direito ao meio ambiente equilibrado.

Sem dúvida, o progresso técnico contribui muito para o surgimento de questões problemáticas antes sequer cogitadas, o que ocasiona, após uma reflexão ética profunda e perene, o desencadeamento de um processo de reconhecimento, pelas ordens jurídicas internas e internacionais, de novos direitos que visem a resguardar aqueles bens das pessoas ou valores tidos como de relevância para incidência de proteção, atingidos pelas novas realidades decorrentes daquele avanço.

Além disso, com vistas a oferecer maior efetividade à proteção da pessoa em sua essencialidade, é preciso considerá-la não apenas abstratamente, como visto, mas em sua concretude, o que redunda, por exemplo e conforme ao tema do presente trabalho, em um mais específico resguardo dos direitos das crianças e adolescentes de acordo com o peculiar estado de ser humano em desenvolvimento.

Essas afirmativas demonstram que o processo de aperfeiçoamento dos direitos

\footnotetext{
${ }^{122}$ Nota-se a recente reforma do sistema público de saúde levada a cabo nos Estados Unidos ("Patient Protection and Affordable Care Act"), cuja constitucionalidade está sob julgamento da Suprema Corte, que busca ampliar o espectro de serviços e de pessoas que podem usufruí-los.

123 SARLET. Ingo Wolfgang. A eficácia dos direitos fundamentais. p. 56.
} 
humanos é contínuo e inesgotável. Exige, de modo intermitente, uma atitude de ponderação com vistas ao esclarecimento a respeito da existência das novas contingências nascidas, que procurem estabelecer a melhor maneira, jurídica e prática, de proteção das pessoas envolvidas com estas e de acordo com as especificidades reais. Não se pode olvidar que o ser humano é o referencial primeiro e último dos direitos fundamentais ${ }^{124}$.

Em algumas situações, exige-se uma diversidade de tratamento. Nesse caso, importante é que exista um fator de discrímen razoável e que justifique a diferenciação concedida. Em outros casos, relativos a certos direitos que dizem respeito ao ser humano de um modo geral, não dependendo seu reconhecimento de características especiais, a salvaguarda dos direitos de todos se dá indistintamente.

Não há dúvidas de que a ética e os direitos humanos, por consequência, são direcionados ao justo, ao bem viver do homem livre, modificando-se apenas o modo de obtenção ou confirmação do conteúdo dos comandos que lhes digam respeito.

Todavia, não é unicamente uma razão humana "a priori” que estabelece, de maneira definitiva, aquilo que seja ético e de acordo com os direitos humanos ou fundamentais, e sim o contínuo processo de abertura democrática e contraditória de crítica a determinadas escolhas normativas que, enquanto resistam a tal teste, possam ser consideradas como positivas ou, melhor dizendo, eticamente justificáveis.

Mister, portanto, além de o sistema jurídico definir certos conteúdos como direitos fundamentais, bem como estabelecer os instrumentos necessários à sua implementação e observância obrigatória, que seja garantido aos destinatários dos comandos normativos o controle de tais direitos, através do devido processo legal. O legislador apenas faz uma primeira opção, cujo controle ético é efetuado por aqueles que são os verdadeiros titulares do poder e destinatários da proteção normativa ${ }^{125}$.

124 “Essa multiplicação (ia dizendo 'proliferação') ocorreu de três modos: a) porque aumentou a quantidade de bens considerados merecedores de tutela; b) porque foi estendida a titularidade de alguns direitos típicos a sujeitos diversos do homem; c) porque o próprio homem não é mais considerado como ente genérico, ou homem em abstrato, mas é visto na especificidade ou na concreticidade de suas diversas maneiras de ser em sociedade, como criança, velho, doente, etc. Em substância: mais bens, mais sujeitos, mais status do indivíduo". BOBBIO. Norberto. ob. cit. p. 68.

125 "Na concepção democrática, a produção e a aplicação do direito passam pelo acertamento prévio dos direitos fundamentais no plano instituinte e constituinte (isegórico) como derivante lógico da isonomia que, como princípio processual, só é enunciável em base de simetria paridade entre os interlocutores. Portanto, a isonomia, como princípio jurídico instituinte da fundamentalidade constitucional de direitos, é encaminhadora de pressupostos de paridade dos atores jurídico-procedimentais a possibilitar o exercício do contraditório e da ampla defesa que integram a instituição do devido processo na constitucionalidade 
Em que pesem os direitos humanos significarem, originalmente, uma proteção ao indivíduo em face do Estado, ou satisfação de certos interesses por este, já se fala atualmente de uma feição vertical de tais prerrogativas fundamentais. Isso significa a aplicabilidade nas relações privadas entre partes que não se encontram em posição de hierarquia e subordinação.

Assim é que, no plano do direito privado, a concretização de alguns desses direitos fundamentais, sobretudo os de primeira geração, inerentes à pessoa, dá-se, exatamente, por meio do reconhecimento positivo dos chamados direitos da personalidade $^{126}$.

Os direitos da personalidade são direitos subjetivos, os quais têm como objeto os atributos essenciais do ser humano individualmente considerado, e de acordo com sua inserção no meio social em suas projeções físicas, intelectuais e morais ${ }^{127}$.

O reconhecimento da existência dos direitos da personalidade determina a salvaguarda de certos atributos titularizados por todos os seres humanos, em razão daquela condição especial acima retratada, dotando-os das qualidades de intransmissíveis, irrenunciáveis $^{128}$, imprescritíveis, impenhoráveis, vitalícios, extrapatrimoniais, alguns com repercussões “post-mortem”, necessários e oponíveis "erga omnes"129.

Há uma certa contenda acerca da existência de um direito geral de personalidade, ligado à própria natureza humana, e que serviria como fonte dos demais, ou pelo contrário, da necessidade de enumeração expressa de direitos de personalidade especiais, atomizados, só caracterizados como essenciais por conta do reconhecimento jurídico que lhes confere a ordem jurídica. O primeiro posicionamento vem ganhando relevância nos diferentes direitos positivos alienígenas ${ }^{130}$.

democrática, para criação, exercício e realização dos direitos fundamentais". LEAL, Rosemiro Pereira. "Processo e eticidade familiar constitucionalizada". In PEREIRA, Rodrigo da Cunha (coord.). Afeto, Ética, Família e o novo Código Civil. Belo Horizonte: Del Rey, 2004. pp. 593-606. p. 602.

126 GOGLIANO, Daisy. “Autonomia, bioética e direitos da personalidade”. In: Revista de Direito Sanitário. V. 1, nº 1, nov. de 2000. São Paulo: LTr, 2000. pp. 107-127. p. 112.

127 GARCIA, Enéas Costa. Direito geral da personalidade no sistema jurídico brasileiro. São Paulo: Editora Juarez de Oliveira, 2007. p. 20.

128 Em geral, já que o Código Civil, em seu artigo 11, ressalva o caráter cogente destas impossibilidades em casos previstos em Lei.

129 BITTAR, Carlos Alberto. Os direitos da personalidade. $3^{\mathrm{a}}$ ed. rev. e atual. por Eduardo C. B. Bittar. Rio de Janeiro: Forense Universitária, 1999. pp. 11-12.

130 SOUZA, Rabindranath V. A. Capelo de. O direito geral de personalidade. Tese(Doutoramento em Ciências Jurídicas pela Faculdade de Direito da Universidade de Coimbra). Coimbra: Coimbra Editora, 1995. pp. 84-91. 
Acolhe-se a pertinência de uma cláusula geral de personalidade, já que inegavelmente reforçadora das ideias anteriormente desenvolvidas sobre os direitos fundamentais, acerca da necessidade de proteção integral do ser humano, atestando-se, além disso, a sua adequação à realidade constitucional brasileira, com base na aclamada dignidade da pessoa humana, levando em conta as ressalvas e temperamentos efetuados acima.

É preciso ter em mente que, apesar de serem direitos em si não avaliáveis economicamente, ou seja, extrapatrimoniais, por razões diversas, podem acarretar situações pecuniariamente apreciáveis, como ocorre quanto à compensação por danos e utilização econômica de seus desdobramentos pelo titular, a exemplo das vantagens produzidas pelos denominados direitos do autor ${ }^{131}$.

Acrescente-se o fato de serem indisponíveis, não passíveis de alteração ou extinção pelo seu titular, visto que perpetuamente ligados aos atributos que visam a proteger, situação esta que não afasta a possibilidade de seu não exercício temporário e de modo não absoluto, bem como a transferência de eventuais repercussões econômicas a terceiros.

De qualquer modo, são mais relacionados ao objeto do presente trabalho os direitos da personalidade relativos à vida, à integridade física, psíquica e à autonomia do indivíduo.

O artigo 13, do Código Civil, é bem expressivo ao vedar a disposição do próprio corpo, quando importar diminuição permanente da integridade física ou contrariar os bons costumes. Enquadrados no espectro desse dispositivo estão, sem dúvida, a vida e a integridade psíquica.

Ora, a vida, como dito, é o substrato mínimo que permite o reconhecimento dos direitos da personalidade, motivo que afasta a possibilidade de tomadas de medidas injustificáveis, aptas ao perecimento desta. Por sua vez, a integridade física abrange a denominada psíquica, já que esta tem por objetivo a salvaguarda da incolumidade de um dos atributos relativos àquela, entendidas como as manifestações internas e individuais da pessoa, resultantes dos processos cerebrais de cunho biológico. Não fosse suficiente, o próprio reconhecimento de um direito geral de personalidade, baseado na condição única

${ }^{131}$ GARCIA, Enéas Costa. ob. cit. p. 44. 
do ser humano, como ser autônomo, impõe a proteção integral de todos os atributos inerentes à pessoa, o que impõe a vedação à violação da integridade psíquica.

Desse modo, pode-se afirmar que a participação dos seres humanos em pesquisas clínicas está, desde o início, condicionada pelo artigo de Lei citado, não podendo significar o sacrifício da vida e da integridade física-psíquica dos sujeitos, o que, na verdade, consubstancia tudo o quanto dito sobre a necessidade de concretização dos direitos fundamentais.

Evidente que tal constatação, feita de maneira meramente abstrata, parece fora de qualquer problemática, o que não se revela verdadeiro quando se está diante de um caso concreto. Na ocorrência das experimentações clínicas, especialmente as terapêuticas, em que se busca, além do avanço científico-tecnológico, a cura de uma determinada patologia individual do sujeito de pesquisa, como se verá, a situação resolve-se pela utilização do critério riscos $\mathrm{x}$ benefícios. Em tal questão não se permite a participação de uma pessoa quando a perspectiva sobre os riscos se mostrar mais plausível de acontecimento em relação àquela atinente à obtenção de benefícios.

\subsubsection{Breve histórico da bioética}

A Bioética, conforme entende a maior parte dos estudiosos sobre o assunto, é ramo nascido nos Estados Unidos, como resposta ao crescente avanço tecnológico na área médica (por exemplo, evolução do conceito de morte cerebral necessário para transplante de coração, regulação de pesquisas clínicas, criação de novos procedimentos que busquem os modos de aplicá-los da melhor maneira possível, tendo em conta os obstáculos técnicos e financeiros), e o conflito de interesses, referido anteriormente, entre os defensores da mera tecnicidade e aqueles dos direitos humanos e da personalidade. Trata-se da criação de uma classe de mediadores que buscam conciliar aqueles dois grupos opostos.

Segundo a maior parcela da doutrina, o primeiro a cunhar a expressão bioética ("bioethics") no artigo "Bioethics, science of survival"132, em 1970, e depois no livro, em 1971, "Bioethics: bridge to the future"133, teria sido Van Ressenler Potter. Todavia, o alemão Fritz Jahr, já em 1927, foi quem, sob a ideia do reconhecimento de obrigações

\footnotetext{
132 Persp. Biol. Med. 14. pp. 27-153.

133 Englewood Cliffs: Prentice Hall, 1971.
} 
éticas para com todos os seres vivos, usou, efetivamente, o termo bioética ("bio + ethik"), pela primeira vez, em um artigo publicado no periódico alemão "Kosmos"134.

$\mathrm{Na}$ verdade, Potter foi o responsável por sistematizar um conceito cuja definição vinha sendo ensaiada nos anos anteriores a sua obra, em que era cada vez mais crescente, com a evolução tecnológica acelerada, tanto a preocupação com os destinos do planeta, quanto com o do ser humano.

Potter denominou a bioética como ciência da sobrevivência humana, uma ponte entre a ciência biológica e a ética ${ }^{135}$, que procura avaliar o futuro do planeta e da espécie humana, focando sua análise primariamente nas questões ambientais e ecológicas, ou uma ligação entre as ciências biológicas e as ciências humanas. Essa visão, posteriormente, fora ampliada para abarcar outras disciplinas a fim de conceituar a bioética como ética global da vida.

Já o holandês André Hellegers, da Universidade de Georgetown, também utilizou a expressão bioética de maneira pioneira seis meses após o livro de Potter, criando o centro de estudos "Joseph and Rose Kennedy Institute for the study of human bioethics" "136. A este cientista atribui-se a utilização do termo bioética em seu sentido atualmente mais desenvolvido, consagrado e reproduzido, qual seja a da bioética como um vínculo entre a medicina, a filosofia e a ética ${ }^{137}$.

Esse movimento de humanização da ciência e reflexão acerca dos rumos da vida tornou-se mais agudo após a Segunda Guerra Mundial, em que o regime nazista, por meio das famigeradas condutas seletivas que ignoravam por completo a dignidade da pessoa humana, brutalmente mutilou, assassinou e submeteu inúmeros seres humanos a experimentos, expondo-os a graves riscos sob o pretexto da evolução científica.

Após tais acontecimentos, iniciou-se um processo de sistematização universal

134 GOLDIM, José Roberto. "Bioética: Origens e Complexidade”. In: Revista HCPA, 26(2). Porto Alegre, 2006 pp. 86-92. p. 87. Disponível em $<$ www.bioetica.ufrgs.br $>$ Acessado em 20.08.2010.

135 JONSEN, Albert R. "Bioética: Alguns aspectos de sua gênese e de seu desenvolvimento - O nascimento da bioética". In: PESSINI, Leocir; DE BARCHIFONTAINE, Christian de Paul. Problemas atuais de bioética. $8^{\mathrm{a}}$ ed. rev. e ampl. São Paulo: Edições Loyola, 2008. p. 47.

136 "Posteriormente, esta denominação foi alterada apenas para Kennedy Institute of Ethics, refletindo a sua posição de entender a bioética como uma ética aplicada. Esta instituição foi a responsável pela formação inicial de muitos profissionais que estavam interessados em atuar em bioética”. GOLDIM, José Roberto. "Bioética complexa: uma abordagem abrangente para o processo de tomada de decisão". In: Revista da AMRIGS, 53 (1): jan.-mar. 2009. Porto Alegre, 2009. pp. 58-63. p. 59. Disponível em $<$ www.bioetica.ufrgs.br $>$. Acessado em 23.08.2010.

137 JONSEN, Albert R. ob. cit. p. 48. 
do regramento das pesquisas em seres humanos com vistas à elaboração de um corpo normativo que possibilitasse o atendimento de mínimos padrões bioéticos, embora ainda não se utilizasse tal termo, aptos a proteger a saúde e a liberdade dos indivíduos, conhecido como o Código de Nuremberg ${ }^{138}$.

Percebe-se, portanto, uma dualidade de sentidos atribuídos à bioética no momento de seu nascimento. Uma que se atrela às questões ecológicas e de sustentabilidade do planeta e visa a discutir a própria existência da espécie humana e a sua convivência com a Terra, enquanto outra busca raciocinar criticamente sobre as consequências futuras advindas do rápido desenvolvimento tecnológico e sua influência sobre a vida humana.

A segunda abordagem interessa mais ao presente trabalho, ao analisar de que maneira pesquisas clínicas com crianças e adolescentes, essenciais ao desenvolvimento científico, devem se desenrolar.

De qualquer modo, é necessário ter como premissa básica para o presente estudo que:

[a] bioética é conseqüentemente aprimorada pelo diálogo entre as diferentes tradições do pensamento, sejam elas de vertente secular ou religiosa, refletindo a diversidade da esfera pública. Tal diálogo exige um conjunto de virtudes, que dizem respeito ao discurso global, entre outras, respeito mútuo, tolerância, civilidade e abertura para mudar a partir da clarificação dos fatos empíricos e persuasão dos outros ${ }^{139}$.

138 “A primeira declaração internacional atinente à investigação com seres humanos foi o 'Código de Nüremberg' de 1946, que surgiu por conta da Segunda Guerra Mundial, em razão dos desmandos nazistas nos campos de concentração, onde realizaram pesquisas abusivas com as pessoas. Com este Código nasceu o termo 'consentimento voluntário e informado'. Em 1964, um conjunto de regras foi adaptado pela Associação Médica Mundial na XVIII Assembléia Geral, com o nome de 'Declaração de Helsinki I'. Surge ali uma versão de novas e muito importantes disposições que prevêem que os protocolos experimentais para investigação em sujeitos humanos devem ser remetidos a um comitê independente especialmente designado para que os aprecie, faça observações e proporcione assessoria e controle. Posteriormente, em 1975, na XIX Assembléia de Tóquio, aparece a 'Declaração de Helsinki II' como versão integrativa e melhorada do Código de Nüremberg e da Declaração de Helsinki I. (La primera declaración internacional con respecto a la investigación con seres humanos fue el 'Código de Nüremberg' de 1946, que surgió a raíz de la Segunda Guerra Mundial, a propósito de los desmanes nazis en los campos de concentración donde experimentaron malévolamente con las personas. Con este Código nació el término 'consentimiento voluntario e informado'. En 1964, un conjunto de reglas fueron adaptadas por la Asociación Médica Mundial en la XVIII Asamblea General, con el nombre de Declaración de 'Helsinki I'. Surge allí una versión de nuevas y muy importantes disposiciones que prevén que los protocolos experimentales para investigación en sujetos humanos deben ser remitidas a un comité independiente especialmente designado para que los considere, haga observaciones y proporcione asesoramiento y control. Posteriormente, en 1975, en la XIX Asamblea de Tokio, aparece la 'Declaración de Helsinki II')". GALINDO, Gilberto Cely. "Principios bioéticos e investigación en clínica humana". In: El horizonte bioético de las ciencias. Santafé de Bogotá: Centro Editorial Javeriano, 1995. p. 312.

139 JONSEN, Albert R. ob. cit. p. 57. 
Em suma, a bioética é, acima de tudo, reflexão interdisciplinar entre as várias áreas do conhecimento, afinal busca estabelecer diálogos críticos entre as ciências médicas, a Filosofia, o Direito e os anseios sociais sobre a realidade das coisas, tendo como início, fim e limite o respeito ao ser humano ${ }^{140}$.

Cada avanço tecnológico, e o processo que culmina em tal, deve ser objeto das devidas discussões críticas direcionadas à aferição de sua efetividade e nível de respeito à incolumidade da vida humana. Não pode ser enxergada, assim, a bioética sob o único prisma da solução de conflitos "a posteriori"141.

Portanto, é evidente que não se pode delegar unicamente aos profissionais técnicos que trabalham na área médica a avaliação sobre as práticas no âmbito da saúde,

140 "Todos os seres humanos, os aplicadores do direito e em especial os médicos, os biólogos, os geneticistas e os bioeticistas devem intensificar a sua luta em favor do respeito à dignidade humana sem acomodações e com muita coragem, para que haja efetividade dos direitos humanos. A consciência destes é a maior conquista da humanidade, por ser o único caminho para uma era de justiça, solidariedade e respeito pela liberdade e dignidade de todos os seres humanos. A bioética e o biodireito estão inseridos nessa conquista, por serem instrumentos valiosos para a recuperação dos valores humanos". DINIZ, Maria Helena. $O$ estado atual do biodireito. $2^{\mathrm{a}}$ ed. aum. e atual. de acordo com o novo Código Civil (Lei $\mathrm{n}^{\mathrm{o}} 10.406$ de 10.01.2002). São Paulo: Saraiva, 2002. p.20.

141 "Com o dito até o momento, tem-se mostrado um nexo de união entre filosofia e bioética que vai além de uma relação de cercania. O ponto de partida consiste em que a bioética é uma parte da tarefa de reflexão racional sobre a conduta moral em que consiste a ética. A tese básica que defendi se resume na afirmação de que a bioética, concebida como mera ferramenta de resolução de conflitos, trata-se de uma insustentável instrumentalização que pode levar à pura e perigosa arbitrariedade. Por isto critiquei as aproximações que esquecem os elementos de fundamentação, restringindo sua atividade ao procedimento, e mostrei a tarefa ética como o quê fazer muito mais amplo e múltiplo. O elemento que tem servido de guia na análise é a consideração da pergunta antropológica como tema filosófico com graves consequências para a bioética. E temos concluído que os problemas bioéticos, na medida em que tratam da vida e, em muitos casos, especificamente da vida humana, fazem referência sempre a uma definição do ser humano. Finalmente, ao falar de uma ética da vida, a necessária distinção entre vida biológica e vida biográfica abriu ainda mais o panorama desta questão, enriquecendo e matizando a pergunta antropológica, e mostrando novas perspectivas na bioética. (Con lo dicho hasta el momento se ha mostrado un nexo de unión entre filosofía y bioética que va más de alla de una relación de cercanía. El punto de partida ha sido que la bioética es una parte de la tarea de la reflexión racional sobre la conducta moral en que consiste la ética. La tesis básica que he defendido se resume en la afirmación de que la bioética, concebida como mera herramienta de resolución de conflictos es una insostenible instrumentalización que puede llevar a la pura y peligrosa arbitrariedad. Por ello he criticado las aproximaciones que olvidan los elementos de fundamentación, restringiendo su actividad al procedimiento, y he mostrado la tarea ética como un quehacer mucho más amplio y múltiple. El elemento que ha servido de guía en el análisis ha sido la consideración de pregunta antropológica como tema filosófico con graves consecuencias para la bioética. Y hemos concluido que los problemas bioéticos, en tanto que tratan de la vida $\mathrm{y}$, en muchos casos específicamente de la vida humana, hacen referencia siempre a una definición del ser humano. Finalmente, al hablar de una ética de la vida, la necesaria distinción entre vida biológica y vida biográfica ha abierto aún más el panorama de esta cuestión, enriqueciendo y matizando la pregunta antropológica, y mostrando nuevas perspectivas en bioética)". GRANDE, Lydia Feito. "Por qué Bioética?". In: GRANDE, Lydia Feito (ed.). Estudios de Bioética. Madrid: Dykynson, 1997. pp. 3-18. p. 16. 
bem como os avanços tecnológicos de tais atividades, devendo tal análise necessariamente sofrer a interferência da Filosofia e de outros ramos de conhecimento, por exemplo, o Direito, para que se evitem abusos tendentes a ferir princípios básicos de respeito ao homem e à vida em sociedade.

\subsubsection{O paradigma dos princípios}

Inúmeros paradigmas foram doutrinariamente estabelecidos no sentido de pautar como deveria se realizar o estudo dos problemas relacionados à bioética. Pode-se identificar, dentre outros, os paradigmas antropológico, personalista, contratualista, do direito natural, do cuidado, narrativo, fenomenológico e hermenêutico, casuístico, das virtudes e libertário $^{142}$.

Todavia, aquele que foi e é ainda o mais reproduzido nos textos científicos e normativos sobre o tema bioética é, sem sombra de dúvidas, o denominado paradigma dos princípios.

O paradigma nasce com o Relatório Belmont (“Belmont Report”) de 1978, editado pela "National Commission for the protection of Human Subjects of Biomedical and Behavioral Research", órgão criado pelo governo dos Estados Unidos, em resposta à continuidade de experimentos clínicos abusivos mesmo após a Segunda Guerra Mundial $^{143}$.

Em tal documento está presente a finalidade de efetivar um completo estudo acerca das experimentações com seres humanos, buscando identificar os princípios orientadores dessas pesquisas a fim de evitar o cometimento de novas afrontas e de produção de resultados lesivos às pessoas. Assim é que esse relatório identificava três

${ }^{142}$ Cf. PESSINI, Leocir; DE BARCHIFONTAINE, Christian de Paulo. Problemas atuais de bioética. $8^{\mathrm{a}}$ ed. rev. e ampl. São Paulo: Ediçoes Loyola, 2008. pp. 62-67.

143 "É importante ressaltar que na origem da reflexão ética principialista norte-americana está a preocupação pública com o controle social da pesquisa em seres-humanos. Em particular, três casos notáveis mobilizaram a opinião pública e exigiram regulamentação ética: 1) em 1963, no Hospital Israelita de doenças crônicas de Nova York, foram injetadas células cancerosas vivas em idosos doentes; 2) entre 1950 e 1970, no hospital estatal de Willowbrook (NY), injetaram hepatite viral em crianças retardadas mentais; 3) desde os anos 40, mas descoberto apenas em 1972, no caso de Tuskgee study no Estado de Alabama, foram deixados sem tratamento quatrocentos negros sifilíticos para pesquisar a história natural da doença. A pesquisa continuou até 1972, apesar da descoberta da penicilina em 1945. O governo norteamericano, em 1996, pediu desculpas públicas àquela comunidade negra pelo que foi feito”. Idem. p. 77. 
princípios: o da autonomia, o do benefício ${ }^{144}$ e o da justiça.

Apesar de se referir, em um primeiro momento, às pesquisas clínicas, as conclusões contidas no relatório acabaram transbordando esses limites, espraiando sua atuação por todo o campo da bioética.

De qualquer modo, o Relatório Belmont define a autonomia como respeito pelas pessoas e incorpora em sua definição

ao menos duas convicções éticas: primeiro, que os indivíduos devem ser tratados como agentes autônomos, e segundo, que as pessoas com autonomia diminuída necessitam de proteção. O princípio do respeito com as pessoas, então, divide em duas as exigências morais: a necessidade de reconhecer a autonomia e a de proteger aqueles com autonomia diminuída ${ }^{145}$.

Observa-se que nessa ideia a autonomia do indivíduo, ainda que mitigada, é pressuposto básico para qualquer intervenção experimental que se efetue com este. É a viga mestra de todo sistema, garantindo ao menos a disposição do próprio corpo pelas pessoas. Caracteriza-se, dessa forma, o fundamento principal da bioética, reconhecendo, conforme o dito anteriormente, a condição especial do ser humano ${ }^{146}$. O respeito à autonomia, conforme se verá posteriormente, não é apenas formal, na verdade, demanda uma série de procedimentos aptos a assegurar que os indivíduos estarão, de maneira consciente, atuando livremente.

A autonomia, na relação médico-paciente, teve inúmeras modificações no correr dos tempos, passando-se de uma visão altamente paternalista, em que ao médico era dado decidir, de maneira inquestionável, os rumos de um tratamento, até se chegar a um cenário de igualdade relacional, com a participação cada vez mais ativa do paciente, essa é a abordagem conferida pelo Relatório Belmont.

Já o princípio do benefício impõe que o objetivo de qualquer procedimento biomédico seja trazer o bem à pessoa singularmente considerada, ou à humanidade, de

\footnotetext{
144 A maior parte dos textos brasileiros sobre bioética realiza a tradução literal do termo para princípio da beneficência. Entretanto, pelo significado mais específico que este termo possui, no sentido de filantropia, prefere-se utilizar o termo benefício.

145 "At least two ethical convictions: first, that individuals should be treated as autonomous agents, and second, that persons with diminished autonomy are entitled to protection. The principle of respect for persons thus divides into two separate moral requirements: the requirement to acknowledge autonomy and the requirement to protect those with diminished autonomy".

146 GOGLIANO, Daisy. ob. cit. p. 110.
} 
maneira mais geral, o que não permite a realização de intervenções que não sejam justificáveis sob esse prisma. De maneira estrita, deve ser entendida como "uma dupla obrigação, primeiramente a de não causar danos e, em segundo lugar, a de maximizar o número de possíveis benefícios e minimizar os prejuízos"147.

A justiça, em tal caso, relaciona-se à distribuição dos riscos e benefícios e ao tratamento dispensado às pessoas, que deve ser efetuado de modo equânime, sem quaisquer tipos de preconceitos e diferenciações infundadas ${ }^{148 .}$.

Posteriormente, Tom L. Beauchamp e James F. Childress ${ }^{149}$, valendo-se das ideias do Relatório Belmont, desenvolveram uma verdadeira teoria principialista, aplicável à prática clínica e assistencial, sem ser restrita às pesquisas médicas.

Para esses autores, os princípios seriam quatro: benefício (beneficência), nãomalefício $^{150}$, justiça e autonomia, que não teriam qualquer tipo de hierarquia entre $\mathrm{si}^{151}$.

${ }^{147}$ KIPPER, Délio José; CLOTET, Joaquim. "Princípios da beneficência e não-maleficência". In: COSTA, Sérgio Ibiapina Ferreira; GARRAFA, Volnei; OSELKA, Gabriel. Iniciação à bioética. Brasília: Conselho Federal de Medicina, 1998. p. 45.

148 "Quem deve receber os benefícios da pesquisa e suportar os seus encargos? Esta é uma questão de justiça, no sentido de 'equidade de distribuição', ou 'do que é merecido'. Uma injustiça ocorre quando algum benefício a que uma pessoa tem direito é negado sem uma boa razão, ou quando algum encargo é imposto indevidamente. Outra maneira de conceber o princípio da justiça seria aquela em que o igual deve ser tratado igualitariamente. No entanto, esta afirmação exige explicação. Quem é igual e quem é desigual? Quais considerações justificam o afastamento da distribuição igual? Quase todos doutrinadores permitem que as distinções baseadas na experiência, a idade, a privação, a capacidade, mérito e posição algumas vezes constituam critérios justificadores do tratamento diferenciado, para determinados fins. É necessário, então, explicar no quê as pessoas devem ser tratadas igualitariamente. (Who ought to receive the benefits of research and bear its burdens? This is a question of justice, in the sense of 'fairness in distribution' or 'what is deserved'. An injustice occurs when some benefit to which a person is entitled is denied without good reason or when some burden is imposed unduly. Another way of conceiving the principle of justice is that equals ought to be treated equally. However, this statement requires explication. Who is equal and who is unequal? What considerations justify departure from equal distribution? Almost all commentators allow that distinctions based on experience, age, deprivation, competence, merit and position do sometimes constitute criteria justifying differential treatment for certain purposes. It is necessary, then, to explain in what respects people should be treated equal)". ESTADOS UNIDOS DA AMÉRICA. Belmont Report (Relatório Belmont). Disponível em $<$ http://ohsr.od.nih.gov/guidelines/belmont.html $>$. Acessado em 13.01.2010.

149 Principles of biomedical ethics. $5^{\mathrm{a}}$ ed. New York: Oxford University Press, 2001.

150 Também nesse caso opta-se pela utilização deste termo, em detrimento daquele usado pela doutrina em geral, qual seja não-maleficência.

151 "Nos últimos vinte anos a opinião de Beauchamp e Childress conseguiu uma aceitação quase universal. Os autores assumem, em geral, que os quatro princípios são 'prima facie' do mesmo nível, acrescentando que somente as circunstâncias e as consequências podem ordená-los.(En los últimos veinte años la opinión de Beauchamp y Childress ha conseguido una aceptación casi universal. Los autores han asumido en general que los cuatros principios son prima facie del mismo nivel, añadiendo que sólo las circunstancias y las consecuencias pueden ordenarlos)". GRACIA, Diego. "Cuestión de Principios". In: GRANDE, Lydia Feito (ed.). Estudios de Bioética. Madrid: Dykynson, 1997. pp. 19-42. p. 26. Todavia, o autor rebate esta assertiva, aduzindo que " se todo este argumento é correto, então os quatro princípios da bioética devem se ordenar em dois níveis: um privado, que compreende os princípios da autonomia e 
Tais princípios seriam de observância obrigatória, assim como as regras postas.

Ressalta-se que se adicionou ao rol previsto pelo Relatório Belmont o princípio do não-malefício, com o desdobramento e mitigação dos limites do princípio do benefício, podendo aquele ser definido como a obrigação de não causar danos e estar este adstrito às noções de "prevenir danos, retirar danos e promover o bem"152.

A doutrina dos princípios foi adotada como modo de solução infalível e único pela bioética por muitos anos, porém atualmente foi atenuada, cedendo espaço à ideia da bioética como campo interdisciplinar e solidário, em que diversos pensamentos, regras e argumentos devem estabelecer uma profunda e constante comunicação reflexiva com vistas à solução dos problemas de vida e de viver ${ }^{153}$.

$\mathrm{Na}$ verdade, a doutrina acima descrita representou um modo didático de carrear aos profissionais da área da saúde conceitos bastante familiares aos atores do mundo jurídicos, elaborados de forma genérica e de fácil compreensão.

O Relatório Belmont e a obra de Beauchamp e Childress, apenas vieram sistematizar, em termos conceituais, os valores admitidos como positivos e que devem

benefício, e outro público, com o de não-malefício e justiça. Os dois primeiros princípios definem aquela parte da vida moral em que todos devemos ser respeitados em nossa diversidade; e os dois outros princípios, os deveres morais que devem ser iguais e comuns para todos os membros da sociedade (...). Brevemente, os quatro princípios bioéticos, longe de serem do mesmo nível, estruturaram-se em dois patamares distintos, que definem duas dimensões da vida moral: a privada, composta pelos princípios da autonomia e benefício, e a pública, formada pelos do não-malefício e justiça. A relação entre estes dois níveis se governam por duas regras. A primeira, ou genética, diz que cronologicamente o primeiro nível é anterior ao segundo. A segunda, ou hierárquica, afirma que em caso de conflito entre deveres desses níveis, os deveres do nível público possuem sempre prioridade sobre os do privado. ([s]i todo este razonamiento es correcto, entonces los cuatro principios de la bioética deben ordenarse en dos niveles: uno privado, que comprende los principios de autonomía y beneficencia, y otro publico, con los de no maleficencia y justicia. Los dos primeros principios definen aquella parte de la vida moral en la que todos debemos ser respetados en nuestra diversidad; y los otros dos principios, los deberes morales que deben ser iguales y comunes para todos los miembros de la sociedad (...). Brevemente, los cuatro principios bioéticos, lejos de ser del mismo nivel, se hallan estructurados en dos niveles diferentes que definen dos dimensiones de la vida moral: la privada, compuesta por los principios de autonomía y beneficencia, y la pública, formada por los de no-maleficencia y justicia. Las relaciones entre estos dos niveles se hallan gobernadas por dos reglas. La primera o genética dice que cronológicamente el primer nivel es anterior al segundo. La segunda o jerárquica afirma que en caso de conflicto entre deberes de esos dos niveles, los deberes del nivel público tienen sempre prioridad sobre los del nivel privado”. pp. 28- 29. Esta discussão assume importância na questão da conciliação entre os princípios em situações extremas, como por exemplo o conflito entre a autonomia e a justiça, em casos em que sejam produzidos benefícios aos indivíduos, sem qualquer tipo de manifestação prévia através de um termo de consentimento informado. Estas questões-limite serão melhor tratadas no capítulo destinado às pesquisas clínicas.

152 KIPPER, Délio José; CLOTET, Joaquim. ob. cit. p. 47.

153 "Nada pode colocar em dúvida a sua utilidade. O maior inimigo do principialismo é o sue próprio êxito e a excessiva simplificação de seu conteúdo. (Nadie puede poner en duda la suya utilidad. El mayor enemigo del principialismo es su propio éxito y la excesiva simplificación de su contenido)". GRACIA, Diego. ob. cit. p. 21. 
reger as relações que tenham por objeto a saúde da pessoa humana. Valores esses cuja encampação pelos sistemas jurídico-normativos é fruto da evolução ocidental acerca da Ética, do Direito e do paradigma do respeito ao homem.

Não há inovação propriamente dita, uma vez que tais princípios trazem em seu bojo parâmetros utilizados para a aferição da eticidade e licitude das condutas humanas, ainda que tais critérios tenham sido abandonados em algumas épocas, cedendo espaço ao abuso e ao horror.

É notável que estes princípios não excluem outros tidos como fundamentais no que tange à integridade física e psíquica do ser humano, como o da igualdade material, e dão conteúdo à chamada dignidade humana.

Além disso, nenhum desses princípios, por óbvio, tem aplicação absoluta, devendo a sua incidência ser verificada e ponderada caso a caso.

$\mathrm{Na}$ realidade, os princípios possuem a tônica de facilitar o trabalho dos agentes envolvidos no campo da bioética, com intuito de oferecer a estes atores conceitos mínimos cuja aplicação é mais facilmente justificável ${ }^{154}$. Todavia, não se pode mais incorrer no erro de conferir aos princípios o papel de única baliza bioética, que se deve pautar, como visto, por um diálogo interdisciplinar entre os vários campos do conhecimento. É preciso levar em consideração, também, as diferentes realidades e os diversos valores envolvidos que vão muito além do benefício, não malefício, autonomia e justiça.

O próprio conteúdo dos quatro princípios é de difícil alcance, o que não retira, entretanto, a necessidade de que sejam preenchidos, nem tampouco a sua utilidade para a avaliação das questões bioéticas.

Não se deve perder de vista que os diferentes modelos teóricos, quer baseados em virtudes, princípios ou casuísta dentre outros, são complementares entre si. O diálogo entre esses paradigmas é que permite o encontro da mais efetiva solução para os problemas que tangenciem a bioética dentro de uma determinada realidade.

A bioética necessita retomar, sobretudo, a tradição humanista de respeito às

154 “Os princípios da bioética representaram a busca de construção de uma ética normativa prática capaz de orientar médicos e cientistas sobre o que seria eticamente razoável diante dos novos questionamentos suscitados pelos avanços da ciência, especialmente no campo da genética - que fizeram surgir dúvidas até então inexistentes. Basearam-se, assim, nos valores tradicionalmente aceitos pela comunidade médica e científica e têm, ainda hoje, norteado a atuação de conselhos de medicina, comitês de ética de hospitais e institutos de pesquisa”. FERNANDES, Elizabeth Alves. Bioética e direitos humanos: a proteção da dignidade da pessoa humana na era da genética. Dissertação(Mestrado pela Faculdade de Direito do Largo São Francisco da Universidade de São Paulo). São Paulo, 2008. 163 p. p. 29. 
diversidades culturais e de opiniões, buscando sempre o melhor caminho possível para garantir a todos, de acordo com suas peculiaridades, a dignidade de vida desde o seu nascedouro até o término. Todavia, como se verá, esse mundo perfeito deve, em algumas ocasiões, ceder espaço à força impositiva do Direito, de acordo com os aspectos constitucionalmente definidos dentro de um Estado verdadeiramente democrático.

A Bioética é, assim, destinada à reflexão, decisão e regulamentação sobre as relações de vida e de modo de viver, estabelecidas entre o ser humano, seus pares e o mundo em que habitam ${ }^{155}$. Necessita, para ser efetiva, de uma constante reavaliação dos fatos, dos dados e opiniões anteriormente obtidos, em uma postura de aceitação perene de ideias divergentes, bem como das necessidades específicas de cada povo e de cada lugar do planeta, sem abandonar, contudo, um certo universalismo quanto a questões basilares que envolvam os atributos essenciais da pessoa humana.

Pensar e exercer a bioética é aceitar a diferença, a constante reflexão que tenha por norte o contato efetivo entre as ideias de diferentes ramos de conhecimento e a mudança de paradigmas, caso isso seja necessário à maior efetividade da proteção da pacífica, respeitosa e solidária convivência entre os homens e os elementos que compõem o ambiente que os cerca. A tomada de decisões, no tocante aos assuntos de bioética, pressupõe uma complexa troca de informações entre os diferentes personagens envolvidos.

\subsubsection{O papel do Direito na regulamentação bioética: a necessidade de normatização plena deste campo}

O Direito deve se valer da bioética como fonte informadora dos problemas e parâmetros gerais que norteiam as atividades objeto de sua análise.

A partir de tal visão, que se demonstra em seu nascedouro multidisciplinar, cabe ao Direito e aos estudiosos, além de regulamentar os conflitos existentes, agir de maneira mais ampla, definindo limites do que seja aceitável ou não no tocante à evolução biotecnológica, tendo em vista, sempre, o seu fim principal: a proteção do ser humano. E tal tutela cabe ao Direito como um todo, considerado em suas múltiplas especialidades.

Não se deseja afirmar que o Direito é autossuficiente; pelo contrário, está-se a

obre a adequação das ações que envolvem a vida e o viver”. GOLDIM, José Roberto. "Bioética: Origens e Complexidade". p. 91. 
constatar que a base de construção de normas jurídicas deve ser o diálogo estabelecido pela bioética. Em tal caso, caberia ao Direito, como sistema impositivo e dotado de coercibilidade, ingressar na discussão, bem como buscar mecanismos de controle que afastem os perigos advindos da evolução da prática biotecnológica.

O Direito, como instrumento por excelência das relações sociais e como encampador dos valores considerados como desejáveis pelos integrantes da comunidade e pelo Estado, deve ser informado pela bioética, ao mesmo tempo em que regulamenta o objeto de estudo desta e participa da construção dela.

Por mais que se preguem essas ideias nos âmbitos das ciências biológicas, não se pode deixar aos próprios operadores das áreas médicas e de pesquisa biológica e biomédica a tarefa de regulamentação total das próprias atividades, baseada em supostos valores éticos universais, ou mesmo construída sob uma lógica utilitarista, com sentido vago a permitir o manejo das mais variadas, assistemáticas e, por isso, perigosas maneiras.

Necessita a ordem jurídica tomar posição nessa seara, a fim de poder, baseada, por primeiro, nas disposições constitucionais, adequar o desejável avanço científico aos demais valores tidos como dignos de proteção, conformando a realização das pesquisas, especialmente em se tratando das clínicas, relativas a experiências com novas substâncias que atuem na saúde do indivíduo, ao quanto estabelecido pelo ordenamento como lícito. Não se deve admitir que determinada área, por que tenha diretrizes científicas próprias, escape à atuação cogente da Constituição e das outras leis que se estendem pelo ordenamento.

\begin{abstract}
À bioética, neste contexto, cabe o papel de levantar as questões, registrar as inquietações, alinhar as possibilidades de acerto e de erro, de benefício e de malefício, decorrentes do desempenho indiscriminado, não autorizado, não limitado e não regulamentado de práticas biotecnológicas e biomédicas que possam afetar, de qualquer forma, o cerne da importância da vida humana sobre a terra, vale dizer, a dignidade da pessoa humana. Mas o papel da bioética certamente esgota-se neste perfil, sem decidir qual a humanidade que a atual geração quer para si e para as futuras gerações. Este papel é o papel do biodireito, como se tem convencionado chamar" ${ }^{\text {"156. }}$.
\end{abstract}

156 HIRONAKA, Giselda Maria Fernandes Novaes. "Bioética e biodireito: revolução biotecnológica, perplexidade humana e prospectiva jurídica inquietante". In: CANEZIN, Claudete Carvalho (coord.). Arte Jurídica - Biblioteca Científica de Direito Civil e Processo Civil. v. 3, nº 1. Curitiba: Juruá, 2006. pp. 2337. p. 25. 
É óbvio que o rápido processo de desenvolvimento tecnológico demande respostas, ao Direito, cabíveis à realidade ${ }^{157}$, sendo imperioso que juristas e legisladores encontrem mecanismos que permitam, ao mesmo tempo, o progresso científico, com a realização de pesquisas clínicas e a proteção dos sujeitos envolvidos nela, principal finalidade da ordem jurídica.

Como se verá mais adiante, no tocante às pesquisas clínicas, já existem dispositivos normativos direcionados à regulamentação desta matéria, positivados sob a forma de Resoluções, principalmente, do Conselho Nacional de Saúde, como a de número 196/96, ou mesmo através de códigos deontológicos. Todavia, tais regulamentações se mostram insuficientes em relação a determinadas áreas de aplicação, como aquelas relacionadas aos experimentos com crianças e adolescentes, objeto principal do presente estudo, que necessitam ser adequadas aos mandamentos constitucionais e legais ora vigentes.

É certo que as disposições existentes possuem alguma utilidade, servindo de parâmetro, no atual momento, à realização dos testes de novos produtos médicos e farmacêuticos. Entretanto, é necessário, que as questões gerais, principalmente da bioética relativas à participação de crianças e adolescentes em pesquisas clínicas, sejam tratadas por Leis formais, que possuam suficiente força normativa dentro do contexto brasileiro.

Não se pode delegar exclusivamente ao Poder Executivo e aos próprios profissionais das áreas biomédicas o regramento de relevante matéria, o que vai de encontro a tudo quanto afirmado anteriormente acerca da necessidade de que o Direito estabeleça sua força diretiva e impositiva em âmbito tão sensível, sob o risco de se subverter todo o arcabouço constitucional. Ora, como admitir que mera resolução trate de pesquisas clínicas com crianças e adolescentes, desconsiderando todo o processo de proteção formado pela Constituição Federal e pelo Estatuto da Criança e do Adolescente, corpos normativos situados em níveis mais elevados da pirâmide jurídica? Impossível e ilegítimo $^{158}$.

\footnotetext{
157 “O que há é apenas este imenso descompasso entre o avanço tecnológico e a normatização jurídica, que precisa ser, com urgência, redimensionado". Idem. p. 36.

158 "Juntando-se todo este arcabouço de informações acerca da diversidade de papéis, o que resta de concreto, neste atual estágio de cuidados à volta do tema, é a de constatação, na atualidade, de uma perfeita ausência legislativa, de um total vazio de normas regulamentadoras de tais condutas e práticas (...).". E conclui, aduzindo, adicionalmente que "[t]ambém não integram o padrão de efetividade e de integral alcance que só a norma jurídica pode ter, as denominadas regulamentações alternativas, às quais
} 
Regulamentações efetuadas de tal maneira, em virtude da inexistência de um procedimento formal para sua modificação, tendem, além disso, a abrir uma possibilidade perigosa de transformações normativas sem um processo de discussão prévio e democrático, mais suscetíveis a interesses outros, como a eventual pressão da gigante indústria farmacêutica.

Nota-se que o Direito possui a tarefa de impor limites à técnica científica, ainda que o processo anterior de tomada das posições seja pautado pelo diálogo, conforme exposto, o que aliás deveria ser o norte aplicável a todas as elaborações normativas que tangenciem áreas extremamente sensíveis como as que presentemente são tratadas ${ }^{159}$. E mesmo que não haja um consenso entre os atores do campo científico, é imprescindível o desenvolvimento tecnológico ceder espaço à imposição Constitucional.

Portanto, defende-se neste trabalho o constante diálogo, no campo da bioética e, mais especificamente, das pesquisas clínicas, a perene troca de informações entre os diferentes setores sociais, para que se estabeleça um sistema normativo capaz de possibilitar o avanço científico e tecnológico, desde que em conformidade com os valores constitucionalmente eleitos como desejáveis, que, em última análise, refletem a preocupação com a efetiva proteção do ser humano ${ }^{160}$.

se tem recorrido - à fala daquelas outras - como, por exemplo, os códigos deontológicos. Tais regulamentações, por não serem legais, são desprovidas de juridicidade, são destituídas de cogência e de sanção, e,por isso mesmo, são ineficazes, não se prestando, por forma alguma, como substitutivas da norma legal. Permanece o vazio ...”. Ibidem. pp. 26-27.

159 Em sentido parcialmente diverso: “[a] força da ciência e técnica está, exatamente, em apresentar-se como uma lógica utópica de libertação que pode levar-nos a sonhar para o futuro inclusive com a imortalidade. Tudo isso deveria, pois, desaconselhar as tentativas de impor uma ética autoritária, alheia ao progresso científico. Deveria, além disso, induzir-nos a evitar formulações de regras jurídicas estabelecidas sobre proibições. É preferível que os vínculos e os 'limites' das leis sejam declinados positivamente e que seja estimulada uma moral autógena, não imposta mas inerente. Em outras palavras, é necessário que entre os sujeitos éticos-jurídicos não seja desprezada a contribuição daqueles que vivem a dinâmica própria da ciência e da técnica (os cientistas), sem chegar, todavia, a delegar a estes decisões que dizem respeito a todos". GARRAFA, Volnei. "Bioética e Ciência - Até onde Avançar sem Agredir". In: COSTA, Sérgio Ibiapina Ferreira; GARRAFA, Volnei; OSELKA, Gabriel. Iniciação à bioética. Brasília: Conselho Federal de Medicina, 1998. pp.99-109. p. 105.

160 "Nos grandes centros de pesquisa dos Estados Unidos não é perigoso participar de experimentos científicos. De acordo com a Comissão de Estudos de Problemas Éticos em Pesquisa Médica, Biomédica e Comportamental, ligada ao Ministério da Saúde dos Estados Unidos, a taxa de risco que pode ser atribuída à experimentação feita naquele país é extremamente baixa. Essa afirmativa mostra que não tem sentido proibir, pura e simplesmente, a pesquisa clínica com base na idéia de que os experimentos causam dano. Por outro lado, também não se deve concluir daí que não é preciso regulamentar a experimentação com seres humanos só porque nos experimentos conduzidos dentro dos Estados Unidos a possibilidade de dano é remota. É provável que as estatísticas americanas indiquem riscos tão baixos exatamente porque naquele país existe regulamentação para a experimentação com seres humanos". HOSSNE, William Saad; VIEIRA, Sonia. "Experimentação com seres humanos: aspectos éticos". In: SEGRE, Marco; COHEN, 


\subsection{Pesquisas clínicas com crianças e adolescentes}

\subsubsection{Considerações sobre as experimentações clínicas em geral}

A evolução das técnicas, tratamentos e produtos destinados ao melhoramento constante da saúde e bem-estar dos indivíduos é, em larga medida, acompanhada pelo desenvolvimento e aprofundamento das pesquisas científicas ${ }^{161}$.

Nesse contexto, ao passarmos para o âmbito dos experimentos com seres humanos, realizados após uma etapa laboratorial prévia, inclusive com a utilização de animais ${ }^{162}$, entra-se em um grande e delicado campo, envolvendo os riscos e limites que podem ou não ser assumidos e ultrapassados pelos condutores de tais pesquisas ${ }^{163}$.

Historicamente, inegável que o século XX foi o grande palco da evolução médica e farmacêutica, o que somente se tornou possível, em grande escala, mediante a administração de pesquisas envolvendo seres humanos ${ }^{164}$, quer em uma posição voluntária,

Cláudio. Bioética. 2a ed. ampl. São Paulo: EDUSP, 1999. pp. 126-146. p. 133.

161 "Do latim perquirere - procurar em diligência, procurar por toda a parte, indagar com profundidade, buscar com cuidado e empenho, pesquisa exprime tanto na jurídica, como nas demais ciências todo trabalho persistente no encaminhamento de um problema, de uma idéia particular ou de uma intuição que leve à descoberta de novos princípios e processos. Não há setor da natureza ou da atividade humana que por ela não possa ser abrangido, nem época da história da humanidade em que, mais do que a atual, centenas de milhares de especialistas no mundo inteiro não se lhe tenha dedicado". CHAVES, Antônio. "Pesquisa em seres humanos". In: Revista de Informação Legislativa, v. 27, no 108, out./dez. 1990. Brasília, 1990. pp. 229-252. p. 230.

162 "Todo avanço no tratamento da saúde e dos processos fisiológicos e patológicos devem necessariamente ser provados primeiro em animais de laboratório e em última instância em seres humanos.(Todo adelanto en el ejercicio de la salud y en los procesos fisiológicos y patológicos pertinentes deben necesariamente ser probados primero en animales de laboratorio y en ultima instancia en sujetos humanos)". GALINDO, Gilberto Cely. ob. cit. p. 309.

163 "Relembre-se que a pesquisa é, por excelência, o campo do risco, e que a responsabilização, quando envolvidos seres humanos, só deve ser admitida com estrita observância dos princípios constitucionais e éticos que a autorizam. A reparação de danos decorrentes de riscos desconhecidos e imprevisíveis, em algumas situações, acima designadas especiais, é imperativa, por força do princípio da solidariedade e da cláusula geral de tutela da pessoa humana. No caso da pesquisa envolvendo pessoa humana, essa tutela deve ser diferenciada, em razão da sua situação de vulnerabilidade potencializada, e em certos protocolos de pessoas já vulneradas, como os doentes". BARBOZA. Heloisa Helena. "Responsabilidade civil em face das pesquisas em seres humanos: efeitos do consentimento livre e esclarecido". In: MARTINSCOSTA, Judith; MÖLLER, Letícia Ludwig. Bioética e responsabilidade. Rio de Janeiro: Forense 2009. pp. 205-234. p. 217.

164 "A pesquisa em seres humanos é tão antiga quanto a medicina, pelo seu caráter especulativo e observador, e continuará sempre pela necessidade de avançar em novos processos diagnósticos, terapêuticos e preventivos. Já nos Cânones da Medicina, escrito pelos chineses 200 anos a.C., e no Juramento Hindu de Iniciação, havia referências ao assunto, embora muito vagamente. A experimentação científica foi mencionada de forma bem precisa, pela primeira vez no juramento da Escola Médica de Berlim". FRANÇA, Genival Veloso de. Direito médico. $9^{\mathrm{a}}$ ed. rev. atual. e ampl. Rio de Janeiro: Forense, 2007. p. 
quer em uma posição de execrável coação ${ }^{165}$.

Como já mencionado, após a Segunda Guerra Mundial, e as horríveis práticas efetuadas pelo nazismo, sob o pretexto da evolução científica, iniciou-se um processo de regramento universal dos estudos científicos em seres humanos com vistas à elaboração de um corpo normativo que possibilitasse o atendimento de mínimos padrões bioéticos ${ }^{166}$, aptos a proteger a saúde e a liberdade dos indivíduos.

Embora se possa identificar a gênese da normatização supra-referida, os anos que se seguiram ainda foram palco de inúmeras pesquisas realizadas sem qualquer preocupação legal e ética, consequentemente causando prejuízos à saúde e às vidas dos integrantes de comunidades inteiras, logo foram repetidos em menor escala e até em países desenvolvidos, os mesmos procedimentos adotados pelos regimes autoritários.

O aprofundamento da normatização dessas pesquisas ocorre, mais precisamente, a partir da década de 60, com a Declaração de Helsinque I, posteriormente modificada ${ }^{167}$,

413.

165 “Admite-se que as ciências experimentais, a partir das quais se desenvolveram os outros ramos da ciência, têm como marco inicial simbólico as contribuições e, sobretudo, a postura de Galileu no século XVI. Desde então os avanços científicos se fizeram de tal forma que, ao final de dois séculos, configurou-se e consolidou-se a chamada Revolução Científica. No século XX, a evolução científica e tecnológica apresentou ritmo tão vertiginoso a ponto de se pode falar em mais duas revoluções, no mesmo século: a revolução atômica, na primeira metade do século, e a revolução molecular, a partir da década de 50 e cujo auge está sendo vivenciado nos dias de hoje. Por outro lado, desde Galileu o número de cientistas vivos vem duplicando a cada 10 a 15 anos; estima-se que, hoje, o mundo dispõe de um número de cientistas maior, talvez, que o número total de cientistas que o mundo já teve e morreram, E, caso a curva do crescimento não sofra inflexão, daqui a 10-15 anos teremos o dobro de cientistas em relação aos dias atuais". FREITAS, Corina Bontempo D.; HOSSNE, William Saad. "Pesquisa com Seres Humanos". COSTA, Sérgio Ibiapina Ferreira; GARRAFA, Volnei; OSELKA, Gabriel. Iniciação à bioética. Brasília: Conselho Federal de Medicina, 1998. pp. 193-204. p. 193.

166 "Toda pesquisa em seres humanos deve ser realizada de acordo com três princípios éticos básicos: respeito pelas pessoas, beneficência e justiça". PESSINI, Leocir; DE BARCHIFONTAINE, Christian de Paul. ob. cit. p. 289.

167 A primeira modificação ocorreu com a Declaração de Helsinque II, referida anteriormente. Esta sofreu algumas modificações posteriores como se nota pelo trecho a seguir transcrito: "[f]oi atualizada novamente em 1983, na $35^{\circ}$ Assembléia Geral de Veneza; em 1989, na $41^{\circ}$ Assembléia Geral realizada em Hong Kong; em 1996, na 48 Assembléia Geral da WMA em Somerset West (África do Sul); e em 2000, durante a 52 ${ }^{\circ}$ Assembléia Geral de Edimburgo. Em 2002 e em 2004, foram produzidas duas notas de esclarecimento nos parágrafos 29 e 30 da declaração". Informes da Associação Médica Brasileira. Jornal da Sociedade Brasileira de Cardiologia, $\mathrm{n}^{\circ}$ 88, jul./ago. 2008, p.11., disponível em http://jornal.cardiol.br/2008/jul-ago/outras/amb.pdf. E por último, reforçando tal preocupação com a ética em pesquisas com seres humanos, de maneira complementar ao desenvolvimento do Código de Helsinque II, "[é] assim que surge o documento Diretrizes éticas internacionais para pesquisas biomédicas envolvendo seres humanos, elaborado pelo Conselho para Organizações internacionais de ciências médicas (CIOMS) em colaboração com a Organização Mundial da Saúde, (OMS), Genebra, em 1993. A revisão e atualização das Diretrizes de 1993 começaram em dezembro de 1998 e forma finalmente aprovadas em 2002. Esta última versão estabelece princípios éticos gerais e traz um preâmbulo de 21 diretrizes, contendo uma introdução e uma breve descrição de instrumentos e diretrizes anteriores". 
com o crescente ganho de relevância do chamado consentimento informado. Em relação ao Brasil, a matéria surge regulada em princípio, principalmente, pela Resolução 196/1996 e pela Resolução 251/1997 ${ }^{168}$, ambas do Conselho Nacional de Saúde.

Em relação aos países em desenvolvimento, grupo no qual se inclui o Brasil, em que os mecanismos de controle das pesquisas mostram-se pouco eficazes, o tema da bioética possui ares de atualidade e extrema importância prático-jurídica, para que se afastem os abusos já tantas vezes experimentados ${ }^{169}$.

Voltando à questão em foco, a causa e consequência, simultaneamente, de tal realidade de desenvolvimento tecnológico da medicina ${ }^{170}$, no atual estágio da vida em sociedade, está no fato de que a saúde ganhou relevante papel na vida das pessoas, assumindo verdadeira posição de bem de consumo cada vez mais economicamente explorado. Isso porque houve um aumento reiterado da ânsia dos indivíduos em se manterem com bom estado de saúde, se possível jovial, e em prolongarem a expectativa de vida, delineando-se uma verdadeira obsessão. Essa forte demanda impulsiona o mercado a buscar e descobrir novos produtos médicos e farmacêuticos capazes de atender tal finalidade ${ }^{171}$.

Alia-se a tal situação o fato de a sociedade contemporânea padecer de preocupantes graus de estresse e desenvolver maus hábitos de vida, o que faz nascerem, ou serem cientificamente descritas, novas patologias que sequer eram cogitadas em um passado não tão distante, ratificando, mais uma vez, a necessidade por novos produtos.

PESSINI, Leocir; DE BARCHIFONTAINE, Christian de Paul. ob. cit. pp.285-286 (grifo do autor).

169 “Outra pesquisa emergente é a das pesquisas realizadas por pesquisadores dos países ricos (onde há restrições éticas mais rigorosas) em regiões pobres do mundo, onde há menor rigor ético e legal para pesquisar. Nos países desenvolvidos há maior exigência de estudos das fases I e II e estudos básicos de fase III, além de estudos de vigilância da fase IV e de restrições a estudos com placebos, o que dificulta e encarece as pesquisas. Isso tende a deslocar as pesquisas clínicas para países onde a fiscalização é menos rigorosa. Nesses locais os comitês de ética são mais complacentes, os direitos de cidadania menos respeitados e, consequentemente, há maiores facilidades para pesquisar e custos menores". MOTA, Joaquim Antônio César. "A criança na pesquisa biomédica”. In: CASABONA, Carlos María Romeo; QUEIROZ, Juliane Fernandez (coords.). Biotecnologia e suas implicações ético-jurídicas. Belo Horizonte: Del Rey, 2005. pp. 46-62. p. 54.

170 "A melhoria das condições básicas de sobrevivência das populações decorrente do avanço tecnológico gerador de maiores excedentes de alimentos, de condições sanitárias mais adequadas, de medicamentos mais avançados e de um contínuo aumento das amenidades da vida em geral - é um dos fatores que explicam a crescente preocupação com as questões vinculadas à saúde, característica das sociedades contemporâneas". SCAFF, Fernando Campos. Direito à saúde no âmbito privado. Contratos de adesão, planos de saúde e seguro-saúde. São Paulo: Saraiva, 2010. p. 15.

.pp.14-16. 
No que tange à saúde, por possuir características especiais, já que inerente à própria personalidade e existência viável dos indivíduos, o desenvolvimento de novos produtos para posterior disponibilização ao público em geral requer a realização de uma complexa e longa etapa preparatória, em que é avaliada, de maneira crucial, a eficácia de tais produtos, bem como a sua potencialidade danosa ${ }^{172}$.

Exatamente nesse contexto preparatório surge a pesquisa aplicada em seres humanos, ou clínicas ${ }^{173}$, como imprescindível ferramenta apta a possibilitar a maximização dos resultados com o menor risco de dano possível ao indivíduo no contato com tais produtos relacionados à saúde.

Observa-se que, tecnicamente, existe uma subdivisão em pesquisas nãoterapêuticas, em que se procura apenas avaliar os riscos e benefícios de um novo procedimento em desenvolvimento, e terapêuticas, em que, além desse fim, busca-se proporcionar um benefício direto aos sujeitos pesquisados ${ }^{174}$.

172 "A investigação tem início com a construção de hipóteses e essas são então testadas em laboratórios, in vitro, e em animais. Para que os achados sejam clinicamente úteis, é necessária a realização de experiências em seres humanos; embora cuidadosamente desenhadas, tais pesquisas acarretam algum grau de risco para os participantes. Esse risco justifica-se não por qualquer benefício pessoal ao pesquisador ou à instituição pesquisadora, mas sim pelo seu benefício aos participantes envolvidos e por sua contribuição potencial ao conhecimento humano ou ao prolongamento da vida". PESSINI, Leocir; DE BARCHIFONTAINE, Christian de Paul. ob. cit. p. 283. No mesmo sentido, "[o] desenvolvimento de um novo fármaco é uma operação muito difícil, extremamente técnica e custosa, fruto de pesquisas complexas que exigem a contribuição de cientistas de diversas áreas (química, bioquímica, farmacologia, toxicologia, técnica farmacêutica, bioestatística, bem como, naturalmente, os diversos ramos da medicina), o emprego de aparelhagem sofisticada, a disponibilização de grandes investimentos. ([1]a messa a punto di un nuovo farmaco è un'operazione molto difficile, estremamente tecnica e costosa, è il frutto di ricerche complesse che richiedono l'apporto di scienziati di discipline assai diverse tra loro (chimica, biochimica, farmacologia, tossicologia, tecnica farmaceutica, biostatistica, oltre che naturalmente i diversi rami della medicina), 1 'impiego di attrezzature sofisticate, la disponibilità di ingenti investimenti)". FERRANDO, Gilda. "L`sperimentazione sull'uomo". In: BARNI, Mauro; SANTOSUOSSO, Amedeo. Medicina e Diritto. Milano: Giuffrè, 1995. pp. 231-257.231.

173 "Qualquer investigação em seres humanos, destinada a descobrir ou verificar os efeitos farmacodinâmicos, farmacológicos, clínicos e/ou outros efeitos de produto(s) e/ou identificar reações adversas ao produto(s) em investigação e/ou para estudar absorção, distribuição, metabolismo e excreção dos produto(s) em investigação, com o objetivo de averiguar sua segurança e/ou eficácia. (Any investigation in human subjects intended to discover or verify the clinical, pharmacological and/or other pharmacodynamic effects of an investigational product(s), and/or to identify any adverse reactions to an investigational product(s), and/or to study absorption, distribution, metabolism, and excretion of an investigational product(s) with the object of ascertaining its safety and/or efficacy)". Definição contida no "Guideline for Good Clinical Practice" (Manual de Boas Práticas Clínicas) de 1997, da "European Medicines Agency" (EMEA). Disponível em $<$ http://www.ema.europa.eu/docs/en_GB/document_library/Scientific guideline/2009/09/WC500002874. pdf $>$. Acessado em 22.01.2011.

174 "A distinção se dá entre pesquisa destinada a beneficiar o sujeito e experimentação sem esta finalidade que são comumente referidas como pesquisas terapêuticas e não-terapêuticas. (The distinction was between research intended to benefit the subject and research with no such intention - what are 
Há uma efetiva tensão, no seio dos estudos clínicos, entre riscos e benefícios, sendo que a realização dos experimentos somente será justificável, do ponto de vista da legalidade, quando os prós superarem os contras associados a qualquer procedimento experimental. Esse balanceamento de interesses permite, de maneira ao menos teórica, sustentar a licitude das pesquisas clínicas, o que não afasta a possibilidade de que, em caso concreto, este teste sobre a legalidade apresente-se como negativo.

Evidente que a aplicação de novos produtos em pessoas, com consequências ainda desconhecidas e que possam acarretar danos sérios à saúde delas, inclusive com a possibilidade de óbito, deve ser tratada com o máximo cuidado, merecendo os aspectos jurídicos uma detida análise ${ }^{175}$.

Reconhecida tal realidade e os parâmetros abstratos e concretos que permitam afirmar a licitude de uma experimentação, deve-se atuar no sentido da construção de um sistema que permita minorar aqueles riscos, ou, ao menos, compensá-los, de certa forma, quando inevitavelmente se traduzam em danos ${ }^{176}$.

commonly referred to as therapeutic research and non-therapeutic research)". STEINBOCK, Bonnie; ARRAS, John D.; LONDON, Alex John. Ethical issues in modern medicine. $6^{\mathrm{a}}$ ed. Boston: McGraw-Hill, 2003. p. 794.

175 "Um aspecto particular do progresso e do poder da biomedicina, concerne à atividade médica destinada ao progresso do conhecimento e das chances diagnósticas e terapêuticas, definidas como experimentações no homem, no entanto só legitimamente conduzidas se respeitarem os direitos da pessoa e, portanto, deontologicamente e juridicamente admissíveis se não produtoras de perigos à vida, à integridade, à dignidade e à liberdade da pessoa. (Un aspetto tutto particolare del progresso e della potestà della biomedicina riguarda l'attività medica diretta al progresso delle conoscenze e delle opportunità diagnostiche e terapeutiche, definibile come sperimentazione nell'uomo, peraltro legittimamente attuabile solo nel rispetto dei diritti della persona e pertanto deontologicamente e giuridicamente ammissibile solo se non produttiva di pericoli per la vita, per la integrità, per la dignità e per la libertà della persona)". BARNI, Mauro. Diritti - Doveri. Responsabilità del medico dalla bioetica al biodiritto. Milano: Giuffrè, 1999. p. 177.

176 “É muito importante perceber que o erro humano é, no final, inevitável. Com isto em mente, Perrow afirma ser necessário considerar as possíveis conseqüências dos acidentes que eventualmente ocorrem em todos os ramos da atividade humana e pesar estas em face da utilidade social da atividade em questão. No caso da indústria nuclear, ele conclui que as potenciais consequências de um acidente são tão graves, que a continuidade não pode ser justificada. Por outro lado, ele sugere que a perda ocasional de vidas, ou mesmo as catástrofes muito graves que ocorrem de tempos em tempos na aviação, medicina, transporte e mineração, por exemplo, são justificáveis em relação à sua magnitude e benefícios globais dessas atividades para a sociedade. Isso não significa que nada deve ser feito sobre os acidentes nesses campos de atuação. Embora se tenha que admitir que acidentes nunca serão completamente eliminados, o foco deve estar sempre na melhoria do sistema afim de garantir o maior nível possível de segurança. (It is very important to realize that human error is, in the end, inevitable. With this in mind, Perrow argues that it is necessary to consider the possible consequences of the accidents that will eventually happen in every branch of human endeavour and weigh these against the social utility of the activity in question. In the case of the nuclear industry, he concludes that the potential consequences of an accident are so serious that its continuation cannot be justified. On the other hand, he suggests that the occasional loss of life, or even the quite serious disasters that occur from time to time in aviation, medicine, shipping and mining, 
Desse modo, não há teoria na experimentação com seres humanos, existe realidade, a qual afeta a esfera individual das pessoas envolvidas. A partir desse ponto, é possível concluir que a necessidade de regramentos e questionamentos éticos e jurídicos recai também sobre os procedimentos de experimentação ${ }^{177}$.

Deve-se ressaltar que a fusão entre prática e ciência, e também a necessidade de regulamentação do processo, não se restringe a resultados particulares, mas se amplia para abarcar o próprio procedimento de experimentação em si, cuja realização, que vai além da mera observação, gera efeitos sobre bens altamente sensíveis. ${ }^{178 .}$

É necessário ter em mente, ao analisar as pesquisas clínicas, que os pacientes participantes estão sacrificando um direito individual em prol da sociedade e de interesses econômicos da indústria médica e farmacêutica. Ainda que as pesquisas clínicas possuam fins terapêuticos, remanesce um fundo de solidariedade em relação aos sujeitos de participantes, já que de qualquer modo estarão se submetendo a procedimentos cujos riscos e perigos à própria saúde não são tão previsíveis como o normalmente esperado e que poderão trazer, no futuro, efetivos benefícios às demais pessoas.

Diante de tal afirmação, considerando que tais sujeitos ao ingressarem em experimentos colocam em risco a própria saúde, a legitimidade desta participação e, consequentemente, da pesquisa a ser realizada, depende da avaliação da autonomia da individuo e da importância das finalidades da pesquisa clínica ${ }^{179}$.

for example, are justified in relation to their magnitude and overall benefits to society of these activities. This does not mean that nothing should be done about accidents in these fields of endeavour. Although it has to be accepted that accidents will never be eliminated completely, the focus should always be on improving the system to ensure the greatest possible level of safety)". MERRY, Alan; SMITH, Alexandre McCall. Errors, Medicine and the Law. Cambridge: Cambridge University Press. 2001. p. 52.

177 "Na medida em que o exercício da ciência se interpenetra com a ação prática no mundo, recai sobre o mesmo o predomínio do direito e da lei, da censura social e da aprovação ou desaprovação moral a que está submetida toda ação exterior em um sistema comum. (En la medida en que la ejecución de la ciencia se interpola con la acción en el mundo, cae abajo él mismo predominio del derecho y la ley, la censura social y la aprobación o desaprobación moral, a la que está sometida toda acción exterior en un sistema común)". JONAS, Hans. Técnica, medicina y ética. Sobre la práctica del principio de responsabilidad. Trad. para o espanhol Carlos Fortea Gil. $1^{\text {a }}$ ed. em espanhol. Barcelona: Paidós, 1997. p. 71.

178 "E no que se refere aos experimentos sobre objetos animados, não serve nenhuma imitação, nenhum modelo representativo, já que necessário empregar um original completamente real, e a neutralidade ética termina, no mais tardar, ali onde se chega nos sujeitos humanos. O que se realiza é um ato real, para cuja moralidade o interesse do conhecimento não concede nenhum cheque em branco. ( $Y$ en lo que se refiere a los experimentos sobre objetos animados, no sirve ninguna imitación, ningún modelo representativo, sino que hay que emplear un original totalmente real, y la neutralidad ética termina a más tardar allí donde llega a los sujetos humanos. Lo que se le hace es un acto real, para cuya moralidad el interés del conocimiento no extiende ningún cheque en blanco)". Idem. p. 70

179 "Há sempre aspectos positivos e negativos que permeiam todo este desenvolvimento; é necessário que se 
A decisão sobre a exposição da saúde do ser humano a riscos não pode ceder a pressões externas, tampouco frente a objetivos, comparativamente a tal bem existencial, de somenos importância. É necessário que a escolha tomada seja embasada em proteção significativa de interesse que estejam ao menos no mesmo patamar da liberdade individual e da saúde pessoal ${ }^{180}$.

Ainda assim, as pesquisas devem, mesmo após o ingresso do indivíduo participante, estar totalmente atentas à autonomia: afinal o participante poderá se liberar a qualquer momento do encargo ${ }^{181}$. A gratuidade da conduta do sujeito de pesquisa impõe, ainda, um dever de cuidado bastante acentuado aos pesquisadores e patrocinadores.

Com base no critério que é o da autonomia do indivíduo e da importância das finalidades das pesquisas, deve-se concluir que é necessário priorizar, na participação das experimentações, aqueles indivíduos cuja liberdade individual de escolha, não só psicologicamente, mas intelectualmente e materialmente, seja mais afinada.

tenha controle sobre o potencial de ambos os aspectos destacados, para que os excessos sejam coibidos. $\mathrm{O}$ desenvolvimento das pesquisas científicas precisa ser assegurado, sem o que a ciência não avança. O que precisa ser amplamente discutido, de forma interdisciplinar, é que tipo de avanços a coletividade almeja alcançar". OLIVEIRA, Simone Born de. Da bioética ao direito: manipulação genética e dignidade humana. $1^{\text {a }}$ ed. (ano 2002), $5^{\text {a }}$ tir. Curitiba: Juruá, 2006. p. 69.

180 "Mas no limite entre o mundo exterior comum, compartilhado com outros, e o interior mais próprio, nossa pele, todo direito público se detém. Nem o Estado, nem o próximo necessitado, tem o direito a um dos meus rins; igualmente, os órgãos de um paciente em coma irreversível não podem ser requeridos legalmente para a salvação de outras pessoas, tampouco o interesse público ou bem comum tem direito ao meu metabolismo, a minha circulação, minhas secreções internas, minha atividade neural, ou qualquer outro dos meus acontecimentos internos. Este é o mais privado do privado, a esfera própria não comum, inalienável. Se adicionamos a isto que dentro do progresso médico não estamos ante nenhum caso de emergência pública, não se tem que evitar nenhuma catástrofe (caso em que desaparecem inclusive os últimos direitos privados), que mais precisamente - dito seja de forma sóbria e estatística - a sociedade pode seguir existindo mesmo que o câncer e as doenças cardíacas sigam sem ser controladas por um tempo mais, ver-se-á que o contrato social tem pouco que fazer quanto a esta questão e a voluntariedade é inseparável dela. Existe, como já se pôde notar, uma diferença entre a aspiração moral a um bem comum (como sem dúvida é toda vitória sobre uma enfermidade) e um direito da sociedade a este bem e aos meios para sua realização. (Pero en el límite entre el mundo exterior común, compartido con otros, y el interior más proprio, nuestra piel, todo derecho público se detiene. Igual que nadie, ni el Estado ni el prójimo necesitado, tiene derecho a uno de mis riñones; igual que los órganos del yacente en coma irreversible no se pueden requerir legalmente para la salvación de otros, tampoco el interés publico o bien común tiene derecho a mi metabolismo, mi circulación, mis secreciones internas, mi actividad neural o cualquier otro de mis aconteceres internos. Esto es lo más privado de lo privado, la esfera propia no comunal, inalienable. Si añadimos a esto que dentro del progreso médico no estamos ante ningún caso de emergencia publica, no hay que evitar ninguna catástrofe (caso en el que desaparecen incluso los últimos derechos privados), que más bien - dicho sea de forma sobria y estadística - la sociedad puede seguir existiendo aunque el cáncer y las dolencias cardíacas sigan sin ser controladas por un tiempo más, se verá que el contrato social tiene poco que hacer en esta cuestión y la voluntariedad es inseparable de ella. Existe, como ya hemos hecho notar, una diferencia entre la aspiración moral a un bien común (como sin duda es toda victoria sobre una enfermedad) y un derecho de la sociedad a este bien y a los medios para su realización)". JONAS, Hans. ob. cit. p. 87.

n 77. São Paulo: RBCCRIM, 2009. pp. 7-39. p. 28. 
No presente trabalho, a análise foca-se nas pesquisas clínicas, propriamente ditas. Todavia, de um modo geral, as considerações expendidas poderão se espraiar por outros campos de pesquisas, os quais envolvam crianças e adolescentes, possuam alguma potencialidade lesiva a integridade física e psíquica do menor e que, por conta disso, demandem uma melhor regulamentação, como o caso dos estudos que envolvam novas técnicas cirúrgicas ou tratamentos psicológicos não medicamentosos, dentre outros.

Importa ressaltar que os conceitos bioéticos, já tratados no presente capítulo do trabalho, são aplicáveis às pesquisas clínicas, tendo em vista que este ramo de atividade contribuiu significativamente à etapa inicial do desenvolvimento da Bioética.

Assim, os tão aclamados princípios da autonomia, benefício, não malefício e justiça, também no âmbito ora tratado, possuem grande relevância, em que pese a sua insuficiência, como já criticado anteriormente, e assumem o papel de objeto de expressa encampação tanto pela Declaração de Helsinque, quanto pela Resolução 196/96.

\subsubsection{As fases dos testes com seres humanos de novos produtos médicos e farmacêuticos}

As pesquisas clínicas, necessárias à introdução de uma nova substância no mercado destinada à proteção da saúde dos indivíduos, devem ser compostas por uma série de fases que são estabelecidas pelas Resoluções 196/96 e 251/97, do Conselho Nacional de Saúde.

De pronto, o item III.3, da primeira Resolução citada, fixa as condições básicas para a realização de uma pesquisa envolvendo seres humanos em geral: a adequação científica e possibilidades reais de obtenção de respostas a incertezas; fundamentação prévia em testes realizados em laboratórios, em animais ou mediante outros instrumentos; o conhecimento a ser obtido não puder sê-lo por outro meio; e as probabilidades de benefícios prevalecerem sobre os riscos. Além disso, deve haver uma razoável correspondência entre os meios utilizados e os fins buscados.

Como determinado, existe a preocupação em se aferir, previamente, um mínimo de segurança à substância pesquisada, inclusive com a necessidade, desde que cabível ou não demonstrável por outro meio, de ser aplicada em animais.

Passada a fase preliminar, é imprescindível avaliar o comportamento de 
determinada substância no corpo humano, e assim passa-se à fase verdadeiramente clínica da pesquisa. A partir de então, mostra-se inexorável o acompanhamento por um comitê independente, denominado CEP - Comitê de Ética em Pesquisa, composto por profissionais de diferentes campos do conhecimento, inclusive das ciências humanas, como juristas. O Comitê possui funções aprobatórias, fiscalizatórias, consultivas e decisórias no tocante à determinadas pesquisas ${ }^{182}$.

É preciso ressaltar que a atuação dos CEPs é mais baseada em aspectos morais do que propriamente jurídicos. Não criam normas, ainda que morais, somente as aplicam no caso concreto. Por tal razão, a opinião dos comitês, na verdade, mostra-se como relativamente fraca, pois, além de ser casuísta, não representa um parâmetro seguro e constante aos próprios pesquisadores, instituições de pesquisa e empresas patrocinadoras. A eventual responsabilidade destes entes não é afastada pelo fato de sua conduta estar de acordo com aquilo recomendado pelo comitê de ética ${ }^{183}$.

Além disso, tais comitês não possuem qualquer garantia institucional, ou função constitucionalmente predeterminada que permita afastar de maneira mais efetiva, ainda que não completa, possíveis pressões externas sobre a atuação deles. As decisões não precisam ser exaustivamente justificadas, o que torna o controle dessas mais intrincado.

Questiona-se, desse modo, até que ponto foi prudente o Estado brasileiro deixar unicamente a estes órgãos (associados ou não ao referendo da Comissão Nacional de Ética em Pesquisa - CONEP em algumas situações como abaixo explicitado) decisões que digam respeito à saúde dos indivíduos, principalmente crianças e adolescentes, sem a participação de instituição vocacionada à proteção dos direitos dos menores, como é o Ministério Público, o que forneceria maior legitimidade e segurança jurídica ao processo de experimentação.

De qualquer forma, o acompanhamento pelos CEPs se dá durante toda a realização da pesquisa clínica em que estejam envolvidos os seres humanos, ou seja, em todas as quatro fases definidas pela Resolução 251/1997.

A fase I trata do primeiro estudo em seres humanos, em pequenos grupos de pessoas voluntárias, em geral sadias, de um novo tratamento. Estas pesquisas têm como

\footnotetext{
${ }^{182}$ Cf. item VII - COMITÊ DE ÉTICA EM PESQUISA - CEP, da Resolução 196/96.

183 EUSEBÍ, Luciano. "Controllo etico e tutela penale nella sperimentazione in ambito sanitario". In: Rassegna Italiana di criminologia. Indici 1993, Milano: Giuffrè Editore, 1993. pp. 47-75. pp. 62-63.
} 
escopo definir níveis preliminares da segurança e eficácia da substância ou técnica em estudo.

Na Fase II (Estudo Terapêutico Piloto), visa-se a demonstrar a atividade e estabelecer a segurança em curto prazo do princípio ativo em pacientes afetados por uma determinada enfermidade ou condição patológica. As pesquisas realizam-se em um número limitado de pessoas e frequentemente são seguidas de um estudo de administração.

A Fase III (Estudo Terapêutico Ampliado) representa estudos realizados em grandes e variados grupos de pacientes, com o objetivo de determinar o resultado do risco/ benefício em curto e longo prazo das formulações do medicamento e/ou especialidade medicinal (tratamento) em teste e, de maneira global, o valor terapêutico relativo. Analisam-se as reações adversas mais frequentes, assim como características especiais do tratamento, por exemplo, interações clinicamente relevantes, principais fatores modificativos do efeito tais como a idade, sexo, resistência, condições físicas etc.

Por fim, na fase IV, pesquisas são realizadas depois de comercializado o produto e/ou especialidade medicinal com o objetivo de monitorar o real valor terapêutico, o surgimento de novas reações adversas e/ou confirmação da frequência de surgimento das já conhecidas e as estratégias de tratamento. Nas pesquisas de fase IV devem ser seguidas as mesmas normas éticas e científicas aplicadas às fases anteriores.

A análise do presente trabalho tem mais pertinência com as fases II e III, pois a participação das crianças e adolescentes está condicionada a benefícios terapêuticos, o que exclui a fase I, e em razão do fato de que a fase IV não representa uma etapa de experimentação em que existam riscos e benefícios incertos, mas sim um controle daqueles tratamentos cuja comercialização em larga escala fora autorizada.

Por seu lado, as pesquisas de novas substâncias farmacológicas necessitam de prévia autorização por parte do CONEP, de composição plural, vinculado ao Conselho Nacional de Saúde, conforme previsto no item VIII. da Resolução 196/96.

Nesse ponto, existem sérias discussões com a finalidade de dar maior rapidez ao processo de instituição e desenvolvimento de pesquisas clínicas e desburocratizá-lo, no sentido de que ao CONEP sejam atribuídas apenas funções fiscalizatórias, e não de autorização, mesmo nas áreas específicas em que seja necessária ${ }^{184}$. Aliás, tal fato

184 "Está em discussão atualmente que a CONEP, que este ano completou dez anos, deixe de avaliar protocolos de pesquisa, Em vários outros países, particularmente do leste europeu, o tempo de aprovação 
justificaria ainda mais a tese defendida neste trabalho acerca da necessidade de intervenção do Ministério Público nas pesquisas com crianças e adolescentes.

Quanto aos experimentos clínicas com incapazes, grupo em que se incluem as crianças e adolescentes, existem, a par das acima tratadas, previsões especiais para garantir uma melhor proteção dos indivíduos que o compõem, que serão tratadas em itens posteriores.

\subsubsection{O consentimento livre e esclarecido como requisito básico para a realização de pesquisas clínicas}

Como vimos, a bioética e o biodireito possuem irrefutável embasamento nos chamados direitos humanos, ou fundamentais, que se transmudam em direitos da personalidade quando referidos a interesses especiais, individuais e indissociáveis da pessoa, protegidos pelo simples fato de sua condição humana.

Dentro desse contexto, especial relevo, como visto, até porque pressuposto de uma ordem jurídica a que se possa atribuir o qualitativo de legítima, possui a autonomia dos seres humanos, entendida como a capacidade de autodeterminação, aptidão de estabelecimento de certas condutas pessoais destinadas ao alcance de determinados objetivos em conformidade à ordem jurídica.

No aspecto jurídico, a autonomia pode dizer respeito a dois diferentes campos de atuação do indivíduo: um patrimonial, relativo à possibilidade de disposição dos bens economicamente apreciáveis, expressa na liberdade de contratar, constitucionalmente protegida por meio da livre iniciativa privada; e outro existencial, ligado aos demais direitos da personalidade titularizados por cada indivíduo. Nesse ponto se incluem as decisões pessoais sobre a própria vida e saúde, orientação sexual, estabelecimento de relações afetivas, dentre outras ${ }^{185}$.

de ensaios clínicos é muito mais rápido que no Brasil, que fica, assim, em situação desvantajosa em relação a eles, inclusive quanto à sua escolha como país onde tais estudos podem ser realizados passando a ter um papel de supervisionar o desempenho dos CEPs nesta função". NISHIOKA, Sérgio de Andrade. "Regulação da pesquisa clínica no Brasil: passado, presente e futuro". In: Prática Hospitalar, Ano VIII, n 48, Nov-Dez/2006. $\quad$ p. $25 . \quad 20$ Disponível <http://www.anvisa.gov.br/medicamentos/pesquisa/artigos/artigo ph 48 sergio nishioka.pdf?script=sci arttext \%C0\%03d=S0104-42302006000100025\&lng=en\&nrm=iso $>$. Acessado em 20 de janeiro de 2011.

185 MACHADO, Diego Carvalho. "Autonomia privada, consentimento e corpo humano: para a construção da 
Assim, a Constituição Federal garante como direito fundamental da pessoa a autonomia, o que significa preservar uma esfera de liberdade ao indivíduo em realizar as escolhas que entende pertinentes sobre sua vida, desde que não vedadas por Lei, ou atentatórias a outros direitos fundamentais, de acordo com uma consequente ponderação concreta dos interesses envolvidos em dado caso real.

No âmbito médico em geral, e das pesquisas clínicas em particular, o direito se expressa através da obrigatoriedade na obtenção do chamado consentimento informado daquele que se submeterá à atividade do profissional de saúde ou experimentação científica.

As primeiras referências pontuais a uma prerrogativa dos pacientes, que se assemelha ao que hoje chamamos de consentimento informado, podem ser notadas na jurisprudência dos séculos XVIII, XIX e início do século XX, respectivamente na Inglaterra, França e Estados Unidos, sendo tal noção sistematizada, todavia, apenas na segunda metade do século $\mathrm{XX}^{186}$.

A expressão em si consentimento informado ("informed consent") foi utilizada judicialmente pela primeira vez por um Tribunal da Califórnia, Estados Unidos, no caso em que um paciente de 55 anos, portador de arteriosclerose, passou por uma aortografia translombar diagnóstica, com a utilização de anestesia, que teve como efeito adverso a paralisação permanente de suas pernas. O paciente em questão não havia sido informado sobre o risco deste dano, o que determinou o entendimento por parte do órgão judicial de que o médico está obrigado a oferecer ao paciente todos os dados relevantes e necessários à obtenção de consentimento informado, consequência inexorável de sua autonomia. Tratase de decisão proferida em 1957, no caso "Salgo vs. Leland Stanford Jr. University Board of Trustees", 187.

Observa-se que na Alemanha, desde 1931, existia legislação determinando que,

própria esfera privada na era tecnológica". In: Revista Trimestral de Direito Civil - RTDC, ano 10, vol. 37, jan./mar. 2009. Rio de Janeiro, 2009. pp. 17-52. p. 24.

186 TEIXEIRA, Ivan Lobato Prado. Capacidade e consentimento na relação médico-paciente. Dissertação(Mestrado pela Faculdade de Direito do Largo São Francisco da Universidade de São Paulo). São Paulo, 2009. 210p. p. 99. Também cf. RODRIGUES, João Vaz. O consentimento informado para o acto médico no ordenamento jurídico português. Elementos para o estudo da manifestação da vontade. Coimbra: Coimbra Editora, 2001. pp. 29-35.

187 SIQUEIRA, Maria Fernanda Santos. "Consentimento informado: o direito do paciente à informação, o respeito à sua autonomia e a responsabilidade civil do médico". In: Revista da ESMAPE. Vol. 13, n²7, jan./jun. 2008, Recife, 2008. pp. 377-409. p. 381. 
para a utilização de novas terapias e realização de pesquisas clínicas, fosse obtido o prévio consentimento esclarecido do paciente, fator que não impediu a realização, pelos alemães durante a Segunda Guerra Mundial, de experimentos forçados e absolutamente aviltantes contra os judeus confinados nos campos de concentração. Consequentemente, com o fim da guerra, como citado, surgiu a elaboração do Código de Nuremberg, de pretensões universalistas, que incorpora a necessidade de obtenção do consentimento informado. ${ }^{188}$

Trata-se, portanto, o consentimento informado, de prerrogativa essencial, norteadora das relações interpessoais, especialmente aquelas vinculadas aos denominados direitos existenciais, como a saúde dos indivíduos, garantia inquestionável do basilar direito à autonomia, protegido constitucionalmente.

Indispensável que seja realçado o aspecto informação, com as necessárias precisão e clareza acerca das características dos males que acometem o indivíduo participante da terapia oferecida, o sopesamento dos riscos e benefícios, bem como sobre as demais possibilidades de tratamento disponíveis "a priori"189 ou, no caso de concretização dos riscos, anteriormente apenas potenciais, em prejuízos.

A obtenção do consentimento informado não pode ser encarada como uma mera formalidade vazia de conteúdo, etapa somente necessária ao desenvolvimento da atividade médica livre e exonerada de eventuais responsabilidades. Está-se diante de um processo complexo, de efetivas trocas informativas e opinativas realizadas entre profissionais da saúde e pacientes, em que uma das partes detém os conhecimentos técnicos e a outra, a última palavra sobre a disposição do próprio corpo ${ }^{190}$. A decisão, em realidade, deve ser construída em um ambiente de recíproca confiança, em que não é permitido ao agente de

${ }^{188}$ RODRIGUES, João Vaz. ob. cit. p. 35.

${ }^{189}$ Idem. p. 28.

190 "O consentimento informado refere-se a normas legais que prescrevem comportamentos para os médicos e outros profissionais da saúde em suas interações com os pacientes e prevêem sanções, sob certas condições, se os médicos se desviam de seus imperativos; a uma doutrina ética, centrada no aclamado valor social da autonomia, que promove o direito de autodeterminação dos pacientes no que tange aos tratamentos médicos; e a um processo interpessoal em que estas partes interagem reciprocamente no sentido de selecionar o curso apropriado do cuidado médico. (Informed consent refers to legal rules that prescribe behaviors for physicians and other healthcare professional in their interactions with patients and provide for penalties, under given circumstances, if physicians deviate from those expectations; to an ethical doctrine, rooted in our society's cherished value of autonomy, that promotes patients' right of selfdetermination regarding medical treatment; and to an interpersonal process whereby these parties interact with each other to select an appropriate course of medical care)". BERG, Jessica W.; APPELBAUM, Paul S.; LIDZ, Charles W.; PARKER, Lisa S. Informed consent. Legal theory and clinical practice. $2^{\mathrm{a}}$ ed. New York: Oxford University Press, 2001. p. 3 
saúde atuar no sentido de simplesmente subordinar o paciente ${ }^{191}$, sob o pretexto de uma prevalência técnica Faz-se mister observar que esta prerrogativa permite ao paciente até mesmo refutar o recebimento de informações, depositando toda a confiança no profissional de saúde responsável pelo seu cuidado.

Afora a previsão legal da Resolução 196/96, do Conselho Nacional de Saúde, bem como dos inúmeros documentos internacionais sobre o tema, a participação das pessoas em pesquisas clínicas por si só, em razão da necessidade de respeito aos direitos fundamentais, impõe, de maneira mais marcante, a obtenção do consentimento informado ${ }^{192}$.

A experimentação busca exatamente aferir a eficácia e a segurança de um novo tratamento, ainda sem aplicação em larga escala. Em tal realidade, os riscos envolvidos são muito maiores, já que as eventuais consequências deletérias não são bem conhecidas cientificamente. Ainda, eventuais benefícios terapêuticos, se previstos e possíveis (pois nas pesquisas clínicas, restritivamente, é aceita a participação de sujeitos saudáveis apenas para a verificação dos efeitos adversos), são igualmente incertos, sem uma comprovação segura, diferentemente do que ocorre com os tratamentos terapêuticos já consolidados ${ }^{193}$.

Nesse ambiente marcado de incertezas, não há como negar a necessidade de completa e adequada informação ao sujeito, para que sua decisão reflita de maneira segura um processo racional e verdadeiramente autônomo, com a ponderação dos efeitos positivos

191 “A doutrina anglo-saxã do consentimento informado pretendeu colocar um freio ao paternalismo médico e reconhece o princípio da autonomia de vontade como base. Esta doutrina objetiva promover a autonomia individual e, secundariamente, a adoção de decisões racionais. $\mathrm{O}$ direito à autodeterminação no que tange à integridade psicofísica, que é a sua consequência, é respeitado se cumpridos três requisitos: a) que o paciente atue de modo autônomo e seja dotado de capacidade; b) que exista um consentimento voluntário, livre e informado sobre as bases em que são propostos exames ou tratamentos; c) que se forneça as informações pertinentes. (La doctrina anglosajona del consentimiento informado pretendió poner un freno al paternalismo médico y reconoce con base el principio de la autonomía de la voluntad. Esta doctrina apunta a promover la autonomía individual y, secundariamente, la adopción de decisiones racionales. El derecho a la autodeterminación en cuanto a la integridad psico-física, que es su consecuencia, se respeta si se cumplen tres requerimientos: a) Que el paciente actúe en forma autónoma y dotado de capacidad; b) Que exista un consentimiento voluntario, libre e informado en aquellos supuestos en que se proponen exámenes o tratamientos; c) Que se le brinde información pertinente)". KRAUT, Alfredo Jorge. Los derechos de los pacientes. Buenos Aires: Abeledo-Perrot, 1997. pp. 148-149

192 "O consentimento informado para a experimentação clínica e a investigação em seres humanos evoluiu com alguma distância do consentimento informado para tratamento. Esta diferença evolutiva reside substancialmente, segundo alguma doutrina americana, no facto de o consentimento para tratamento ser um produto da casuística judiciária, enquanto que a experimentação ( e o respectivo consentimento) foi já objecto da actividade legislativa de inúmeros países, por influência, na maioria dos casos, do que se produziu em direito internacional, como reacção ás experiências levadas a cabo durante a II Guerra Mundial em campos de concentração". RODRIGUES, João Vaz. ob. cit. p. 158.

193 BARNI, Mauro; DELL'OSSO, Giuseppe. "I diritti del soggeto nella sperimentazione e nella pratica medica: aspetti medico-legali”. In DELL'OSSO, Giuseppe (coord.). Responsabilità e progresso medico. Milano: Giuffrè Editore, 1984. p. 32. 
e negativos que a tomada de decisões e a participação no experimento clínico podem acarretar.

Na maior parte das vezes, os sujeitos de pesquisa são pessoas de baixos níveis de escolaridade e renda, usuárias dos serviços públicos de saúde, logo, ao ingressarem em uma determinada experimentação, não possuem real consciência sobre o modo e importância da própria participação. São impelidos, geralmente, pelo oferecimento de cuidados especiais e pela autoridade do médico que sugere a inserção no estudo. Todos esses fatores exigem seriedade, cautela e boa-fé por parte dos pesquisadores/patrocinadores ao analisarem as condições pessoais do sujeito e avaliarem a maneira em que ocorrerá a abordagem escolhida ${ }^{194}$.

Claro está, assim, que o efetivo exercício da autonomia depende, sobremaneira, de possuir o paciente informações claras e detalhadas acerca do modo em que será realizada o teste clínico e sobre os riscos dele advindos, a fim de que efetivamente esteja apto a escolher entre ser ou não participante.

Entretanto, não basta fornecer um calhamaço de informações muitas vezes incompreensíveis para o sujeito, é necessário que o pesquisador apresente esses dados relevantes de maneira inteligível. O modo de oferecimento dessas informações deve ser comprometido com a idade, condição social, cultural e intelectual do sujeito voluntário, em um ambiente de tranquilidade e afastado de quaisquer pressões. Aliás, a necessidade de promoção e preservação da igualdade substancial impõe a observância dessa regra.

O oferecimento das informações não deve ser tratado como instrumento de exclusão da responsabilidade, até porque, como será tratado, não o é, precisa ser, na verdade, adequado meio de proteção da integridade, da dignidade do indivíduo. Não é mais uma etapa burocrática, e sim expressão mais alta do respeito e consideração ao próximo.

Além disso, deve haver uma preocupação extrema por parte daqueles que conduzem o estudo em garantir, de modo constante, a renovação das informações relevantes e o entendimento por parte dos sujeitos sempre que houver alguma modificação importante. Inexorável seja esclarecido ao sujeito a possibilidade de, a qualquer momento, abandonar o ensaio realizado, o que garante o pleno exercício de sua autonomia.

Contudo, a atuação dos pesquisadores no esclarecimento real dos pacientes

${ }^{194}$ MENEGUIN, Silmara. ob. cit. pp. 19-20. 
envolvidos nas pesquisas clínicas não tem seguido, de maneira exata, essas premissas. Não se está aqui dizendo haver má-fé dos profissionais, apenas que sua tarefa de informação não tem sido bem desempenhada.

Esta realidade indesejável é constatada em recente estudo, já mencionado em nota anterior do presente trabalho, levado a cabo pela autora Silmara Meneguim com sujeitos de pesquisa. No total foram entrevistadas e avaliadas oitenta pessoas, oriundas de seis diferentes ensaios realizados no Hospital das Clínicas da Universidade de São Paulo.

Verifica a citada autora que $25 \%$ dos sujeitos de pesquisa entrevistados afirmam não terem sido informados sobre a relevância da pesquisa e quase a metade (42,5\%) nem dos riscos e incômodos. Já $82,5 \%$ dos pacientes não receberam informação quanto à existência de tratamentos diferentes daqueles propostos no ensaio. A garantia de sigilo também era desconhecida por quase metade dos sujeitos no momento da entrevista (47,5\%). Ainda, 46,2\% dos sujeitos afirmaram o não recebimento de qualquer diretriz no que tange aos instrumentos adequados de reparação dos eventuais prejuízos advindos da participação na pesquisa. Entretanto, 76,2\% receberam a informação sobre o seu direito de desistência exercitável a qualquer momento, sem afetar o tratamento ordinário na instituição ${ }^{195}$.

Como já se mencionou, a Resolução 196/96, do Conselho Nacional de Saúde traz inúmeras regras a serem seguidas pelos pesquisadores/patrocinadores no tocante à obtenção do consentimento informado, exatamente nos moldes do quanto acima delineado $^{196}$. Na realidade, o modelo se reproduz em vários ordenamentos jurídicos

${ }^{195}$ Idem. p. 54-55.

196 "O respeito devido à dignidade humana exige que toda pesquisa se processe após consentimento livre e esclarecido dos sujeitos, indivíduos ou grupos que por si e/ou por seus representantes legais manifestem a sua anuência à participação na pesquisa.

IV.1 - Exige-se que o esclarecimento dos sujeitos se faça em linguagem acessível e que inclua necessariamente os seguintes aspectos:

a) a justificativa, os objetivos e os procedimentos que serão utilizados na pesquisa;

b) os desconfortos e riscos possíveis e os benefícios esperados;

c) os métodos alternativos existentes;

d) a forma de acompanhamento e assistência, assim como seus responsáveis;

e) a garantia de esclarecimento, antes e durante o curso da pesquisa, sobre a metodologia, informando a possibilidade de inclusão em grupo controle ou placebo;

f) a liberdade do sujeito se recusar a participar ou retirar seu consentimento, em qualquer fase da pesquisa, sem penalização alguma e sem prejuízo ao seu cuidado;

g) a garantia do sigilo que assegure a privacidade dos sujeitos quanto aos dados confidenciais envolvidos na pesquisa;

h) as formas de ressarcimento das despesas decorrentes da participação na pesquisa; e

i) as formas de indenização diante de eventuais danos decorrentes da pesquisa. 
estrangeiros, bem como nos diversos documentos internacionais sobre o tema ${ }^{197}$.

Revela-se, portanto, extremamente necessário seguir de maneira estrita os comandos normativos citados, o que evitaria um déficit informativo dos sujeitos de pesquisa que acaba por redundar em um patente desrespeito a sua autonomia, direito da personalidade indisponível e constitucionalmente garantido. O cuidado com o paciente e os seus direitos fundamentais devem nortear todo e qualquer ensaio clínico, prevalecendo até mesmo em face de outros interesses do paciente e da sociedade em geral, por exemplo, o direito à saúde das demais pessoas.

\subsubsection{Os experimentos com crianças e adolescentes: considerações gerais}

É cristalina a demanda para a criação de novos produtos médicos e farmacêuticos destinados aos juridicamente incapazes, como crianças, deficientes mentais e adolescentes, cujo desenvolvimento necessita da realização de pesquisas em seres humanos que compõem tais grupos ${ }^{198}$.

IV.2 - O termo de consentimento livre e esclarecido obedecerá aos seguintes requisitos:

a) ser elaborado pelo pesquisador responsável, expressando o cumprimento de cada uma das exigências acima;

b) ser aprovado pelo Comitê de Ética em Pesquisa que referenda a investigação;

c) ser assinado ou identificado por impressão dactiloscópica, por todos e cada um dos sujeitos da pesquisa ou por seus representantes legais; e

d) ser elaborado em duas vias, sendo uma retida pelo sujeito da pesquisa ou por seu representante legal e uma arquivada pelo pesquisador.

197 Além das citadas Declarações de Helsinque, Código de Nuremberg, Relatório Belmont, dentre outros, cf., v.g., Declaração Universal sobre bioética e direitos humanos; Convenção sobre os direitos do homem e a biomedicina (Europa); Lei 46/2004 (Portugal), art. 48; Codice de Deontologia Medica (Itália), Artigo 12; Real Decreto 561/1993 (Espanha). Ressalve-se que os ordenamentos jurídicos internos europeus vêm sendo paulatinamente adaptados às convenções estabelecidas no âmbito da União Europeia, como a referida Convenção sobre os direitos do homem e a biomedicina.

198 A partir do século XVIII, com o início das pesquisas clínicas com seres humanos, por terem papel marginal na sociedade, subordinado à vontade dos adultos, as crianças foram objeto de muitas pesquisas, expostas a extremos graus de risco a sua saúde e vida. Tal fato prosseguiu no correr dos séculos XIX e $\mathrm{XX}$, ainda que paulatinamente a criança tenha ganhado uma maior proteção, sobretudo em razão da revolução industrial em que passou a ser vista como força produtiva, perdurou ainda a sua submissão a pesquisas clínicas sem qualquer tipo de limites e preocupações com sua integridade. E note-se que em muito desses casos, isto contava com a anuência dos pais. Caso emblemático é de Albert Sabin, que testou nas suas duas filhas a vacina contra poliomielite, sem saber ao certo sobre a segurança de tal procedimento. Mesmo após a Segunda Guerra Mundial, o Código de Nuremberg, e a Declaração de Helsinque I, continuaram sendo realizadas pesquisas clínicas com crianças de maneira abusiva, inclusive com o apoio da comunidade médica internacional. Mais recentemente, há menos de uma década, as crianças dos países subdesenvolvidos foram as vítimas desses abusos, sendo submetidas a pesquisas clínicas no mínimo duvidosas do ponto de vista ético, como relata Joaquim Antônio César Mota. "A criança na pesquisa biomédica". In: CASABONA, Carlos María Romeo; QUEIROZ, Juliane Fernandez. 
Não há como admitir, em todas as ocasiões, que a execução de testes em adultos seja suficiente para garantir a eficácia e segurança dos novos produtos e procedimentos quando destinados a crianças. Haja vista serem pessoas em formação, cujo estado físico e psicológico difere muito daquele encontrado nos adultos.

As características anatômicas e fisiológicas dos menores, porque peculiares, exigem que os novos tratamentos sejam moldados perfeitamente a essa especificidade. $\mathrm{E}$ tal só é possível mediante a realização de experimentos clínicos com participantes crianças e adolescentes, modo único de considerar, de maneira séria e minuciosa, essas particularidades.

As pesquisas clínicas são necessárias para garantir a evolução científica que permita uma maior proteção da saúde das crianças em geral, com a atenuação dos riscos, que inclusive poderiam ser agravados no caso de se aplicarem tratamentos apenas testados em adultos.

Todavia, não se pode desconsiderar, com base no argumento acima aduzido, a necessidade de proteção individual das crianças que, porventura, venham a participar dessas pesquisas. Aliás, como visto, existe a necessidade imposta normativamente de que a experimentação realizada tenha finalidade terapêutica.

Observa-se, com tal abordagem, uma situação conflitual em que resta prejudicada a determinação prévia do que representa, verdadeiramente, cuidado em relação aos menores, proteção integral e atendimento dos melhores interesses desses indivíduos. Isso não afasta e, na verdade, impõe que sejam traçadas diretrizes gerais aptas a concretizar os princípios citados.

Exatamente por sua peculiar situação de pessoa em formação, e tendo em conta que pesquisas clínicas de novos tratamentos envolvem riscos cujo grau de cognoscibilidade ainda pode ser reduzido, importante tomar as devidas medidas acautelatórias, em verdadeira atitude de precaução. Tais cuidados possibilitam o avanço científico que, em última análise, poderá ser revertido em benefícios para os menores, associado à mitigação dos possíveis efeitos danosos que do processo experimental podem nascer.

Igualmente, surgem questões bastante problemáticas sobre $\mathrm{o}$ modo de implementação das medidas assecuratórias do bem-estar das crianças e dos adolescentes no 
que tange à adequação à demanda de pesquisas com incapazes ${ }^{199} \mathrm{e}$ à própria disposição do corpo desses participantes, com riscos à saúde, uma vez que o consentimento para tal ato sofrerá a efetiva intervenção de um terceiro, quer por meio de assistência, quer por meio de representação ${ }^{200}$.

Portanto, nessa seara, está-se diante de uma área conflituosa, em que a busca pelo cuidado e pela proteção integral e prioritária do melhor interesse da criança e do adolescente, com o devido respeito às especiais demandas e características de tais indivíduos, deva ser o norte de qualquer normatização a ser empreendida.

\subsubsection{Requisitos iniciais para a participação de menores em testes clínicos}

A participação de grupos mais vulneráveis em pesquisas clínicas, especificamente por terem autonomia reduzida, dependerá de uma maior importância dos objetivos visados por uma determinada experimentação. Quanto menor a autonomia do sujeito de pesquisa, mais relevantes devem ser as finalidades buscadas ${ }^{201}$. Mesmo assim, há um limite inferior que

é a capacidade de compreensão e de consentimento (é dizer, também de negá-lo) como tal. Isto exclui tanto os mentalmente deficientes como as relações de obediência militar. Não posso entrar aqui em uma casuística. Mostro somente o princípio de ordem de preferência, visto agora a partir do lado negativo: quanto mais pobre em conhecimento, motivação e liberdade de decisão é o grupo de sujeitos (e isto significa também, infelizmente, o grupo mais amplo e mais disponível), tanto mais cautelosamente, inclusive com resistência, há de ser empregada esta reserva e tanto mais coativa tem que ser a justificação compensatória tendo em conta o objetivo perseguido ${ }^{202}$.

199 "Se existe uma justificativa ética e científica para realizar uma pesquisa com indivíduos incapazes de dar consentimento informado, o risco de intervenções próprias da pesquisa que não proporcionem a possibilidade de benefícios diretos para o sujeito individual não deve ser maior que o risco associado a um exame médico ou psicológico dessas pessoas. Pode-se permitir incrementos leves ou menores desse risco quando existir uma fundamentação científica ou médica superior para esses incrementos e quando um comitê de avaliação ética os tiver aprovado." PESSINI, Leocir; DE BARCHIFONTAINE, Christian de Paul. ob. cit. p. 298.

200 Em sentido contrário, à primeira vista, e reverberando os ensinamentos de DÍEZ-PICAZO, Denise Damo Comel afirma que "[a]tos que impliquem cuidado como a saúde do filho, qual a realização de cirurgias, uma transfusão de sangue ou outra intervenção de natureza médica ou mesmo odontológica, incluem-se na função de criar o filho, de modo que não há que falar em representação legal ou assistência. O pai age no interesses do filho e em cumprimento do dever precípuo do poder familiar". ob. cit. p. 120.

201 JONAS, Hans. ob. cit. pp. 91-92.

202 ([E]s la capacidad de comprensión y de consentimiento (es decir, también de negativa) como tal. Esto 
É necessário, desse modo, reconhecer que a autonomia da criança e do adolescente não está totalmente estabelecida e construída, pois ambos, ainda em formação, não possuem todo o arcabouço informativo necessário à manifestação plena de liberdade, baseada em juízo de livre convencimento construído por suas próprias razões ${ }^{203}$.

Contudo, a participação de crianças e adolescentes em pesquisas clínicas que visem ao seu benefício não pode ser descartada, pois ainda que elas não tenham capacidade de fato, nos termos da lei civil, quer absoluta, quer relativa ${ }^{204}$, elas possuem autonomia, ainda que reduzida e cercada de precauções importantes, de decidirem sobre seu próprio corpo e saúde.

A incapacidade é diretamente relacionada a aspectos patrimoniais da criança e do adolescente, devendo ser garantida a eles certa participação, de acordo com o grau de discernimento que possuam, em escolhas que digam respeito a sua integridade psíquica e física, aos seus direitos da personalidade ${ }^{205}$.

Ressalta-se que o grau de autonomia dos menores será inversamente proporcional ao grau de intervenção dos pais nas decisões a serem tomadas por aqueles, no que tange ao

excluye tanto a los débiles mentales como a las relaciones de obediencia militar. No puedo entrar aquí en una casuística. Muestro sólo el principio de orden de preferencias, visto ahora desde el lado negativo: cuanto más pobre en conocimiento, motivación y libertad de decisión es el grupo de sujetos (y esto significa también, por desgracia, el grupo más amplio y más disponible), tanto más cautelosamente, incluso con resistencia, ha de ser empleada esta reserva, y tanto más coactiva tiene que ser la justificación compensatoria a través del objetivo) Idem. p. 93.

203 "Não há dúvida que a liberdade é um valor, mas que deve ser visto com a devida ponderação, critério e discernimento especialmente no que diz respeito às crianças e jovens que dependem, na fase inicial de suas vidas, do cuidado, do exemplo, da orientação que provêm sobretudo de seus pais, ou seja, das pessoas que deveriam ser as primeiras interessadas em garantir as melhores condições de evolução àqueles que foram por eles criados". SCAFF, Fernando Campos. "Considerações sobre o Poder Familiar". p. 581.

204 Art. $3^{\circ}$ São absolutamente incapazes de exercer pessoalmente os atos da vida civil:

I - os menores de dezesseis anos; (...).

Art. $4^{\circ}$ São incapazes, relativamente a certos atos, ou à maneira de os exercer:

I - os maiores de dezesseis e menores de dezoito anos; (...).

205 “ Com efeito, se operarmos a conexão entre a noção de discernimento (considerado como eixo da Teoria das Incapacidades) e a de bens da personalidade humana então poderemos perceber a existência de especificidades a tornar útil uma idéia nova, qual seja: a da ocorrência de situações em que não é apta ou suficiente a capacidade negocial, (assim compreendida a capacidade para deliberar acerca dos atos, atividades e negócios que impliquem avaliações econômicas ou patrimoniais), pois o que está em causa é exercício de atos atinentes ao núcleo mais irredutível da existência humana. Este núcleo está ancorado nos bens de personalidade 'por excelência', isto é, a vida e a saúde humanas". MARTINS-COSTA, Judith "Capacidade para consentir e esterilização de mulheres tornadas incapazes pelo uso de drogas: notas para uma aproximação entre a técnica jurídica e a reflexão bioética". In: MARTINS-COSTA, Judith; MÖLLER, Letícia Ludwig (orgs). Bioética e responsabilidade. Rio de Janeiro: Forense, 2009. pp. 299344. pp. 321-322. 
exercício dos seus demais direitos da personalidade, ou fundamentais. Conforme vão crescendo, se dotadas de normais condições intelectuais e psíquicas, o processo de aprendizagem e relacionamentos interpessoais acaba dotando-as, constantemente, de mais intenso grau de liberdade ${ }^{206}$.

Afirmar a necessidade de oitiva dos menores sobre o desejo de sofrer intervenções que repercutirão em seu corpo e em sua psique é simplesmente atestar serem titulares de direitos da personalidade e de estarem estes ligados, de maneira inseparável, a cada pessoa individualmente considerada ${ }^{207}$.

Aliás, esse reconhecimento é conferido pelo Estatuto da Criança e do Adolescente em várias passagens. Entretanto, especificamente no que tange às pesquisas clínicas, é necessário que sejam ouvidas as crianças e adolescentes sobre sua participação em experimentos, conforme nos mostra o seguinte dispositivo, alínea $a$, do item IV. 3 , contida na Resolução 196/96:

em pesquisas envolvendo crianças e adolescentes, portadores de perturbação ou doença mental e sujeitos em situação de substancial diminuição em suas capacidades de consentimento, deverá haver justificação clara da escolha dos sujeitos da pesquisa, especificada no protocolo, aprovada pelo Comitê de Ética em Pesquisa, e cumprir as exigências do consentimento livre e esclarecido, através dos representantes legais dos referidos sujeitos, sem suspensão do direito de informação do indivíduo, no limite de sua capacidade.

Regra semelhante é trazida pelo novo Código de Ética Médica, no parágrafo único de seu artigo $101^{208}$, e no item 28, da Declaração de Helsinque VII, de $2008^{209}$.

${ }^{206}$ TEIXEIRA, Ana Carolina Brochado; PENALVA, Luciana Dadalto. "Autoridade parental, incapacidade e melhor interesse da criança. Uma reflexão sobre o caso Ashey". In: Revista de informação legislativa. Ano 45, no 180. Brasília: Senado Federal, 2008. pp. 293-304. p. 296.

${ }^{207}$ BARBOZA, Heloísa Helena. "Poder familiar em face das práticas médicas". In: Revista do Advogado. Ano XXIV, no 76, junho de 2004. São Paulo: AASP, 2004. pp. 40-46. p. 44.

${ }^{208}$ Art. 101. Deixar de obter do paciente ou de seu representante legal o termo de consentimento livre e esclarecido para a realização de pesquisa envolvendo seres humanos, após as devidas explicações sobre a natureza e as conseqüências da pesquisa.

Parágrafo único. No caso do sujeito de pesquisa ser menor de idade, além do consentimento de seu representante legal, é necessário seu assentimento livre e esclarecido na medida de sua compreensão.

209 "Quando um potencial sujeito de pesquisa considerado incapaz está apto para opinar sobre as decisões relativas à participação no experimento, os médicos devem buscar a sua concordância em adição aos consentimento dos seus representantes legais. O dissenso do potencial sujeito deve ser respeitado. (When a potential research subject who is deemed incompetent is able to give assent to decisions about participation in research, the physician must seek that assent in addition to the consent of the legally authorized representative. The potential subject's dissent should be respected)". No mesmo sentido, "[p]otencialmente, a criança é autônoma, para que possa consentir com o tratamento ou cuidados 
Certamente tal processo deve ser efetuado com o maior cuidado, informando-se o menor, de acordo com as suas capacidades, das consequências e riscos envolvidos, buscando retirar ao máximo a influência do temor reverencial dos pais sobre esta escolha $^{210}$.

É necessário que seja utilizada uma linguagem própria de acordo com cada criança ou adolescente envolvido, devendo este procedimento ser acompanhado por uma comissão que envolva médicos pediatras, psicólogos e assistentes sociais, tudo com vistas a assegurar a proteção integral da criança e adolescente e do atendimento de seu melhor interesse.

Não se está a afirmar que deva ser excluída a participação dos pais ou responsáveis legais, ao contrário, tem-se claro que eles são os atores principais sobre o direcionamento da vida dos filhos menores, defendendo-se somente que tal processo decisório conte com efetivos subsídios para a tomada do caminho mais recomendável no sentido do melhor interesse da criança ${ }^{211}$, e sejam estabelecidos mecanismos seguros para a solução imparcial e rápida de eventuais conflitos que possam vir a existir.

Importante assinalar que há uma verdadeira atuação do princípio da precaução, estudado no capitulo 3 , nos procedimentos acima referidos e na complementação defendida no presente trabalho, uma vez que, diante de riscos, defende-se a adoção de procedimentos que tenham por finalidade atenuar a probabilidade de ocorrência desses, ou mitigar os

recebidos, deverá receber informações relevantes, explicações, ter tempo para questionamentos e discussões, a fim de que possa desenvolver conhecimentos relevantes. No simpósio Internacional sobre Bioética e Direito das Crianças, realizado em 2000, foi estabelecido que a criança deve participar das decisões relativas a sua saúde e educação à medida que a sua autonomia se afirmar. Quando houver diferenças de interesses, o interesse da criança deve prevalecer sobre o do adulto. Ou seja, caso a criança recuse a participar de uma pesquisa, sua decisão deverá ser respeitada”. TENGAN, Cristiana; VENANCIO, Paulo César; MARCONDES, Fernanda Klein; ROSALEM, Pedro Luis. "Autonomia e vulnerabilidade do sujeito da pesquisa". In: Revista de Direito Sanitário, vol. 6, ns 1/2/3, São Paulo: LTr, 2005. pp. 25-37. p. 33.

210 “Assim, no raciocínio por concreção, o intérprete deve primeiramente perquirir se o consentimento eventualmente concedido à prática do ato interventivo derivou da conjugação de uma circunstância objetiva (a informação, ou o esclarecimento que serão prestados pelo médico ao paciente para que ele possa discernir) e outra subjetiva (a capacidade do paciente para compreender, ponderar, avaliar, decidir e se autodeterminar em sentido congruente com a compreensão, ponderação e avaliação feitas), pois não se pode considerar 'informada' pelo médico a pessoa que não tem condições pessoais de intelecção e autodeterminação. Essa é a razão pela qual inclusive menores - desde que possam, em algum grau, compreender, avaliar e expressar a sua vontade - são destinatários da informação sobre o ato interventivo em sua saúde, como hoje é internacionalmente reconhecido, devendo ser considerados, para aquele efeito, como capazes de decisão, sendo-lhes atribuída uma espécie de ' maioria antecipada' para tal fim". MARTINS-COSTA, Judith. ob. cit. p. 328.

211 BARBOZA, Heloísa Helena. "Poder familiar em face das práticas médicas”. p. 44. 
efeitos danosos que possam nascer, com a necessidade, também, de que essa avaliação entre riscos, benefícios e medidas assecuratórias adequadas seja renovada durante todo o estudo clínico, e mesmo após.

Reitera-se, neste ponto, que os objetivos da pesquisa clínica devem ser de importância inversamente proporcional à autonomia das crianças envolvidas.

A própria Resolução 196/96, como analisado acima, reconhece a procedência dessa afirmação, impondo, ainda, que as pesquisas clínicas com vulneráveis só poderão ser realizadas caso os objetivos perseguidos não possam ser alcançados com experimentos efetuados com indivíduos que gozem de plena autonomia. Outra questão é que os testes científicos não representem riscos excessivos às crianças, além dos ordinários, considerados como aqueles atinentes aos verificados na vida comum, exceto se a pesquisa possuir em seu bojo a grande possibilidade de trazer efetivos benefícios às crianças e adolescentes envolvidos $^{212}$.

Exatamente por não possuírem autonomia plena, não se pode admitir a participação de menores em pesquisas não terapêuticas ${ }^{213}$, a menos que estas se apresentem como inofensivas, sendo que, nesse caso, a recusa da criança ou adolescente em participar do estudo é absoluta e não pode ser afastada de qualquer modo ${ }^{214}$.

${ }^{212}$ Nos Estados Unidos, seguindo este paradigma, há uma grande restrição às pesquisas com crianças, estendida aos outros incapazes: "[a]s atuais regulamentações federais permitem pesquisas com crianças que representem apenas um incremento ínfimo de mínimos riscos, estando caracterizados estes mínimos riscos quando 'a probabilidade e magnitude do dano ou desconforto previstos para a pesquisa não sejam maiores do que aqueles ordinariamente encontrados na vida cotidiana ou durante a realização de testes e exames físicos ou psicológicos rotineiros. ([t]he current federal regulations permit research on children that is a minor increment over minimal risk where minimal risk is defined as 'the probability and magnitude of harm or discomfort anticipated in the research are not greater in and of themselves than those ordinarily encountered in daily life or during the performance of routine physical or physicological examinations or tests')". STEINBOCK, Bonnie; ARRAS, John D.; LONDON, Alex John. ob. cit. p. 790. No mesmo sentido, MOTA, Joaquim Antônio César. ob. cit. p. 57.

${ }^{213}$ Genival Veloso de França defende que pesquisas clínicas, com quaisquer indivíduos, só podem ser consideradas lícitas se também tiverem finalidades terapêuticas: “[o] homem não é dono absoluto do seu próprio corpo. É apenas um administrador de sua vida, realizando seu destino, com direito a usufruir de sua existência. Não tem o direito ilimitado de autorizar uma prática lesiva contra si. Também não é lícito e admissível o cientista fazer experimentação em si próprio. O homem dispõe de um direito relativo sobre seu corpo. Aceita-se a licitude da experimentação quando ela responde unicamente ao interesse do próprio experimentado. Qualquer pesquisa científica sobre um paciente sem as considerações deste interesse é, indubitavelmente, condenável. O médico não pode usar seu paciente como simples material de estudo. Se o homem tem sobre seu corpo um direito limitado, muito mais limitado é o direito do médico, cuja missão é preservar a vida até onde suas forças e sua ciência o permitam. Toda experimentação deve ter um fim essencialmente terapêutico, e por isso não se pode considerar prática honesta o uso de pessoas humanas com o único objetivo de pesquisar". ob. cit. p. 415.

214 "Nos termos do art. 10. ${ }^{\circ}$, n. ${ }^{\circ}$, [Portugal - Decreto-Lei no $.97 / 94$ de 9 de abril sobre "os ensaios clínicos a realizar nos seres humanos"] 'No caso de menores ou incapazes, só é permitida a realização do ensaio 
No tocante às pesquisas terapêuticas, poderá existir um conflito entre a vontade dos menores em não se submeterem ao experimento e aquela dos pais, no legítimo exercício do seu poder familiar, no sentido da participação dos seus filhos, visando ao cuidado com saúde destes.

Não se adota uma posição apriorística que determine sempre o respeito ao quanto decidido pelos menores. Ao mesmo tempo em que especial e incompleta autonomia de crianças e adolescentes, contudo existente, demanda consideração da opinião deles, esta mesma peculiar situação exige que tal manifestação seja levada a efeito com reservas.

Muitas vezes um receio infundado, ou a impossibilidade de exata compreensão do procedimento experimental e dos benefícios que ele pode oferecer, pode levar o menor a recusar, de maneira injustificável, a participação dos menores em uma pesquisa clínica, ainda que isso signifique a obstrução de medidas necessárias ao cuidado da saúde. Nesses casos, a liberdade dos menores deverá sucumbir à proteção, ou melhor, à busca pelo atendimento do melhor interesse deles que, no caso em tela, significa a participação no experimento.

Se for verificado que a vontade dos pais não corresponde ao atendimento do melhor interesse do menor, no caso concreto posto à apreciação do aplicador do Direito, ela não deverá prevalecer, a exemplo do que ocorre em situações como as das testemunhas de Jeová, em que, por preceitos religiosos, não é permitida a realização de transfusões de sangue. Entre a vida da criança ou adolescente e a opção religiosa dos pais, que não são senhores absolutos dos direitos daqueles, deverá prevalecer a medida mais apta à salvaguarda do menor ${ }^{215}$.

Por óbvio, como imperativo legal e constitucional de respeito à autonomia e de proibição de excessos no exercício do poder familiar, a melhor alternativa é que o suprimento da vontade da criança e do adolescente, no caso conflitivo acima apontado, conte com a participação do Ministério Público, com a intervenção, em último caso, apenas, do Poder Judiciário ${ }^{216}$, conforme o disposto no artigo 1.631, parágrafo único, do

clínico quando resultar benefício clínico directo para o sujeito'. A lei é clara quando exclui os menores e os incapazes de toda a experimentação não terapêutica, ou que só possa ter um benefício futuro e eventual para o sujeito". OLIVEIRA, Guilherme. Temas de Direito da Medicina. Coimbra: Coimbra Editora, 1999. p.198.

215 TEIXEIRA, Ana Carolina Brochado; PENALVA, Luciana Dadalto. ob. cit. pp. 302-303.

216 Heloísa Helena Barboza, sustenta ser necessária sempre autorização judicial para a participação de crianças e adolescentes em pesquisas clínicas, ainda que terapêuticas, posição esta que, como visto, não se 
Código Civil.

A título ilustrativo, tratando-se do procedimento de adoção, e da necessidade de que haja expresso consentimento do adolescente (maior de 12 anos) para a efetivação do processo, conforme previsto no $\S 2^{\circ}$ do artigo 45 do Estatuto da Criança e do Adolescente, Roberto João Elias, entende que se não houver a concordância do adotando,

examinadas todas as circunstâncias, especialmente 'as reais vantagens para o adotando' do art. 43, o Magistrado, não obstante a falta de consentimento, poderá conceder a adoção. A filosofia do Estatuto, em conformidade com o preceito constitucional do art. 227, é assegurar à criança e ao adolescente o direito à convivência familiar, e isso deve ser respeitado ainda que contrariamente à vontade do menor ${ }^{217}$.

Nos dois casos, guardadas as devidas diferenças, está-se diante de escolhas que envolvam aspectos existenciais do menor e justificam a sua oitiva ${ }^{218}$, mas com a ressalva de que este direito de opinião conferido ao indivíduo em formação não é absoluto, não podendo suplantar a busca pelo seu melhor interesse.

Portanto, no cenário das pesquisas clínicas, por envolverem riscos aos menores na busca pela proteção da própria saúde, devem ser adotadas condutas de precaução que visem a efetivar, concretamente, a proteção integral, e de modo prioritário, dos melhores interesses das crianças e adolescentes, bem como é necessário que as disposições regulatórias sejam estabelecidas minuciosamente por meio de Lei, não comportando uma mera resolução a importância dos assuntos ora tratados.

\subsubsection{A necessidade de intervenção do Ministério Público como agente fiscalizador das pesquisas clínicas com crianças e adolescentes}

Como se pôde verificar anteriormente, a proteção da saúde do menor durante a

coaduna com aquela disposta no presente trabalho e que melhor concilia a imprescindível segurança e a busca da cura e avanço científico. "Poder Familiar em face das práticas médicas". p. 45.

217 Comentários ao Estatuto da Criança e do Adolescente: Lei n. 8.069, de 13 de julho de 1990. $4^{\mathrm{a}}$ ed. São Paulo: Saraiva, 2010. p. 56.

218 Ainda que no caso da adoção seja reconhecido tal direito expressamente somente ao adolescente, em outras passagens do próprio Estatuto da Criança e do Adolescente, admite-se a necessidade de que seja considerada a opinião da criança, que não possui a mesma força. 
pesquisa e posteriormente, por conta das suas especificidades como ser humano em desenvolvimento, mais sensível a danos de ordem moral e material, e da autonomia reduzida dele, deve ser bastante meticulosa. A qualidade constitucional do Ministério Público como guardião dos direitos das crianças e dos adolescentes justifica a necessidade de participação ativa deste nos ensaios clínicos que tenham menores como sujeitos.

Tal constatação não significa atribuir uma tarefa decisória ao Ministério Público acerca da realização e dos rumos científicos a serem tomados por uma pesquisa clínica. Propõe-se, na verdade, uma conduta fiscalizatória do "parquet", atribuindo-lhe a possibilidade de acompanhamento dos estudos, e das fases posteriores, para que se verifique a manutenção do processo de desenvolvimento sadio da criança e do adolescente. Para tanto, tem a prerrogativa de requisitar informações, emitir pareceres e buscar a tutela do Poder Judiciário nas situações extremas.

Atualmente, a Resolução 196/96 prevê o controle prévio das pesquisas clínicas, com capazes ou incapazes, efetuados pelos CEPs, que funcionam junto às instituições, previamente autorizadas, e realizam experimentos na área da saúde com seres humanos. Esses colegiados multidisciplinares têm a função de controlar o protocolo do estudo científico e zelar pela integridade dos sujeitos dele participantes. Em alguns casos, será necessário,, como citado, avaliação também por parte do CONEP, e de composição igualmente multidisciplinar ${ }^{219}$.

Todavia, defende-se no presente trabalho a insuficiência, nos atuais moldes, da atuação dos Comitês de Ética em Pesquisa, para o controle dos ensaios clínicos com crianças e adolescentes. Tais estudos, como reiterado aqui, por oferecerem riscos a interesses especiais de seres humanos mais sensíveis, devem ser acompanhados de uma rigorosa fiscalização. Isso porque, no Brasil, objeto de foco crescente dos grandes laboratórios, teve-se a oportunidade de demonstrar que as pesquisas clínicas, via de regra, envolvem pessoas dos patamares mais baixos da sociedade, com pouco acesso à educação e carecedoras dos mais básicos serviços de saúde ${ }^{220}$.

${ }^{219}$ Este modelo reproduz aquele da principal diretriz internacional sobre o tema, o manual de Boas Práticas Clínicas (Good Clinical Practice), e adotado, com pequenas variações, na maior parte dos países, como Itália (Decreto Legislativo 211/2003), Portugal (Lei $n^{\circ}$ 46/2004), Estados Unidos (Code of Federal Regulations, Title 21, Chapter I - Food and Drugs Administration, Subchapter A - General, Part 56, Institutional Review Boards) e Argentina (Resolución 1480/2011 - Ministerio de Salud - M.S.).

220 "O considerável aumento de investimentos em pesquisas clínicas no país e a procura de parceiros em países em desenvolvimento coloca o Brasil entre os países foco de interesse das pesquisas da indústria 
Imperioso que seja afastada, no máximo patamar possível, a possibilidade de criação de um ambiente de conflito de interesses, o qual pode envolver, de um lado, os Comitês de Ética em Pesquisa e a indústria farmacêutica, ou mesmo os pesquisadores, e de outro, os menores, sujeitos da experimentação. Este cenário, é inegável, demanda uma cautela específica, consistente na participação ativa do Ministério Público nos trabalhos desses Comitês.

Há a necessidade de estabelecimento de um ambiente de cooperação entre os CEPs e o Ministério Público e não de uma relação de subordinação daqueles a este, com a finalidade de permitir o desenvolvimento científico, bem como a proteção do próprio interesse dos menores.

O Ministério Público exerceria a função de fiscalização das decisões dos Comitês de Ética, podendo, para o cumprimento da tarefa, requisitar informações, oferecer parecer não vinculante quanto aos ensaios específicos em análise e, em excepcionalíssimos casos, propor as medidas judiciais cabíveis.

A atividade do Ministério Público, importante ressalvar, precisa levar em consideração um dado importante: o de que eventual paralisação infundada de uma pesquisa clínica determinada pode redundar em dano à saúde daquela criança ou adolescente que supostamente se busca resguardar, devido ao caráter terapêutico necessário.

É fato observável que o Ministério Público pode, judicialmente, tanto requerer a paralisação de um estudo em curso, bem como promover as pertinentes responsabilizações de pesquisadores, patrocinadores, pais e responsáveis legais envolvidos no teste clínico.

Além disso, faz-se necessário haver uma real coordenação entre o Ministério Público e o CONEP, em última análise órgão legalmente dotado de maiores conhecimentos técnico-informativos sobre pesquisas clínicas. O próprio CONEP, instado pelo "parquet" pode proceder à paralisação de um determinado ensaio, evitando o acesso desnecessário ao Poder Judiciário. A consulta prévia ao CONEP, aliás, nos casos em que se objetiva a

farmacêutica, junto de México e Argentina na América Latina, Leste Europeu e África do Sul. Entre os fatores que podem explicar tal interesse da indústria por estes países, destaca-se [sic] a prevalência de doenças de países menos desenvolvidos, uma população menos esclarecida em decorrência do baixo nível de escolaridade e submissa às solicitações do médico, e um sistema atual de saúde que gera múltiplas desigualdades que colocam sua população num estado de fragilidade e dependência". MENEGUIN, Silmara. ob. cit. p. 18. 
interrupção de uma pesquisa clínica em andamento, deve ser entendida como elemento necessário à propositura da ação judicial, para que seja preenchida a condição do interesse de agir, exceto nos casos mais urgentes, em que os abusos cometidos sejam evidentes, ou, ainda, possa também estar caracterizado um conflito de interesses no âmbito do CONEP.

Dessa maneira, reconhece-se a importância dos Comitês de Ética em Pesquisa, independentes e multidisciplinares e defende-se a manutenção desses como centro decisório sobre a regularidade dos ensaios científicos. Tal postura adiciona apenas uma nova garantia aos direitos das crianças e adolescentes, consistente na participação mais próxima do Ministério Público, o que atende, sem dúvida, os mandamentos constitucionais e legais já amplamente tratados. 


\title{
3. RESPONSABILIDADE CIVIL
}

\subsection{Risco e Precaução}

\subsubsection{Reflexões sobre o conceito de risco}

Até agora, o presente trabalho abordou várias vezes a questão sobre risco e a consequente precaução que deva ser adotada mediante a possibilidade de tal risco, especialmente no que tange às pesquisas clínicas com crianças e adolescentes. Entender o conceito do que vem a ser risco nessas situações, portanto, é de extrema importância para os fins desta análise, inclusive no que concerne às conclusões expendidas quanto à responsabilidade civil.

Como já se pôde abordar, vive-se atualmente em um mundo de constante evolução científica e tecnológica, que conduz o homem, entendido de forma generalizante, a fronteiras antes desconhecidas. Somos capazes de vislumbrar coisas até então inimagináveis, como o controle de nosso código genético, a criação e reconstrução de partes humanas e a troca de informações de maneira instantânea. $\mathrm{O}$ atual momento de grande desenvolvimento tecnológico, iniciado com a Revolução Industrial no século XVIII, difere muito da antiga visão de técnica. Isso porque, no desenvolvimento vigente antes deste período:

\begin{abstract}
[h]á uma diferença principal, indicada na denominação 'tecnologia', em que a técnica moderna é uma empresa e um processo, enquanto a anterior era um poder e um estado. Se o conceito 'técnica', grosseiramente descrito, denomina o uso de ferramentas e dispositivos artificiais para o negócio da vida, junto com seu invento original, fabricação repetitiva, melhoramento contínuo e, ocasionalmente, também adição ao arsenal existente, tão reflexiva descrição serve para a maior parte da técnica empreendida ao longo da história da humanidade (da mesma idade que ela), mas não para a moderna tecnologia. Isto porque, no passado, o inventário de procedimentos e ferramentas existentes costumava ser bastante constante e tender a um equilíbrio reciprocamente adequado, estático, entre fins reconhecidos e meios apropriados. Uma vez estabelecida esta relação, mantinha-se como um "optimum" de competência técnica sem mais exigências. É certo que se produziram revoluções, no entanto mais por casualidade do que por intenção ${ }^{221}$.
\end{abstract}

221 '(Hay una diferencia principal, la indicada en el nombre 'tecnología', en que la técnica moderna es una 
Pode-se afirmar, nessa esteira, que o risco sempre esteve presente na civilização humana. Todavia, a concepção era mais pessoal, ligada individualmente àqueles poucos que se lançavam a novas descobertas. Não estavam espraiados sobre toda a sociedade, ou seja, não tinham repercussão direta global e constante, como se vê hoje. Conforme relata Ulrich Beck, "[n]aquele período remoto, a palavra risco tinha uma nota de bravura e aventura, não de medo de auto-destruição de toda vida na Terra"222.

Há na perspectiva do risco, como entendido hoje, uma criação humana. É o homem quem cria a ideia de risco, de acordo com algum parâmetro (risco às gerações futuras, risco à vida) frente ao novo. O risco pode, inclusive, ser potencializado dentro da psique dos indivíduos na medida em que se forneçam informações exageradas ou equivocadas acerca da sua potencialidade/previsibilidade ${ }^{223}$.

$\mathrm{O}$ atual estado tecnológico pressupõe que cada nova descoberta abra um leque para novas experimentações, novas buscas, em um movimento incessante, que não provoca, pois, a estabilização da ciência e das técnicas implementadas por ela. $\mathrm{O}$ avanço tecnológico é constante e quase inesgotável, sendo que "[a] relação entre meios e fins neste campo não é linear em só sentido, mas circular em sentido dialético" 224.

A noção de risco é, dessa maneira, originária do processo de modernização, estando ligada ao avanço tecnológico contínuo e às consequências que isso pode acarretar para a existência saudável da sociedade como um todo e de seus componentes

empresa y un proceso, mientras la anterior era una posesión y un estado". Si el concepto 'técnica', burdamente descrito, denomina el uso de herramientas y dispositivos artificiales para el negocio de la vida, junto con su invento originario, fabricación repetitiva, continua mejora y ocasionalmente también adición al arsenal existente, tan reposada descripción sirve para la mayoría de la técnica a lo largo de la historia de la humanidad (de la misma edad que ella), pero no para la moderna tecnología. Porque en el pasado el inventario existente de herramientas e procedimientos solía ser bastante constante y tender a un equilibrio recíprocamente adecuado, estático, entre fines reconocidos y medios apropiados. Una vez establecida tal relación, se mantenía durante largo tiempo como un 'optimum' de competencia técnica sin más exigencias. Cierto, se produjeron revoluciones, pero más por causalidade que por intención). JONAS, Hans. ob. cit. p. 16.

222 "(In that earlier period, the word 'risk' had a note of bravery and adventure, not the threat of selfdestruction of all life on Earth). Risk Society. Towards a New Modernity. Trad. para o inglês Mark Ritter. $1^{\mathrm{a}}$ ed em inglês. $7^{\mathrm{a}}$ reimpr. London: SAGE Publications, 2007. p. 21.

223 Cf. SUSTEIN, Cass. "Para além do princípio da precaução". In: Interesse Publico, Ano VIII, no 37 . Porto Alegre: Notadez Informação, 2006. pp. 119-171. pp. 123-127. Este autor, em texto crítico ao princípio da precaução, enumera algumas razões que estão ligadas à percepção, pelas pessoas, da existência ou não dos riscos envolvidos em alguma atividade.

224 “(La relación entre medios e fines en este campo no es lineal en un sólo sentido, sino circular en sentido dialéctico). JONAS, Hans. ob. cit. pp. 18-19. 
considerados individualmente.

Trata-se de uma tentativa humana de controlar o futuro, de racionalizar, por métodos exatos, as probabilidades de ocorrência de prejuízos frente a novas tecnologias que nos tragam alguma utilidade ${ }^{225}$. É derivação imediata da própria natureza do homem voltada a justificar a tomada de um caminho em detrimento de outro que seria também viável. Consubstancia-se, além disso, em inegável manifestação do instinto de sobrevivência ínsito à existência da pessoa humana, ainda que muitas vezes haja a opção por alternativas que pareçam contrariar tal afirmação.

Analisam-se os danos individuais por óbvio, entretanto, são considerados também em uma dimensão geral. Isso significa que é preciso também estabelecer, em contínua reflexão, a proporção em que devam ser pautadas as atitudes tendentes a mitigar os possíveis efeitos da eventual e concreta efetivação de tais riscos, bem como o modo de distribuição dos resultados alcançados.

O avanço tecnológico, dentro da concepção apresentada, aumenta o arcabouço de situações que possam acarretar riscos, o que torna mais difícil o cálculo destes. Esse processo representa, pois, um contínuo caminho rumo ao novo, ao desconhecido, tocando áreas antes não atingidas, ou agravando os problemas em outros âmbitos de atuação humana ${ }^{226}$.

Avaliando-se o incessante projeto de evolução tecnológica na área farmacêutica e

225 "O risco deve ser avaliado dentro dos parâmetros risco/utilidade e custo/benefício". LOPEZ, Teresa Ancona. Princípio da precaução e evolução da responsabilidade civil. Tese(Concurso de Professor Titular da Faculdade de Direito da Universidade de São Paulo). São Paulo, 2008. 232 p. p. 33.

${ }^{226}$ Hans Jonas, após destrinchar as causas que entende serem as principais e mais palpáveis, mas não únicas, para esse impulso infindável da ciência e da tecnologia frente a novas descobertas, indica assim como tais a constante pressão por competência exercida sobre os profissionais desenvolvedores destas técnicas, a questão da escassez material, frente ao avanço populacional, a ideia utópica instilada nas pessoas de busca incessante por uma vida cada vez melhor, aduz que a verificação dessas causas, individualmente ou conjuntamente, não explicaria o assunto de maneira adequada, o que só poderia ser efetuado entendendo que "todos compartilham uma premissa sem a qual não poderiam fazer seu trabalho a longo prazo: a premissa de que pode haver um progresso ilimitado, por que sempre há algo novo e melhor para encontrar. (todos comparten una premisa sin la cual no podían hacer su trabajo a la larga: la premisa de puede haber un progreso ilimitado, porque siempre hay algo nuevo e mejor que encontrar)". E conclui, aduzindo que "[a] convicção complementar é, então, que uma tecnologia adaptada a uma natureza e uma ciência com tais horizontes abertos desfruta da mesma abertura, sempre renovada no momento de transformá-los em conhecimento prático de tal modo que cada um de seus passos inicia o seguinte e nunca se produz uma quebra por esgotamento interno das possibilidades. (La convicción complementaria es entonces que una tecnología adaptada a una naturaleza y una ciencia con tales horizontes abiertos disfruta de la misma apertura, siempre renovada, a la hora de transformarlos en conocimiento práctico de tal modo que cada uno de sus pasos inicia el siguiente y nunca se produce un parón por agotamiento interno de las posibilidades)". ob. cit. pp. 21/22. 
médica, pode ser percebido que a busca pela quimera da saúde perfeita incorpora ainda mais o objetivo entre os atuantes nessa área. O fato é perigoso, tendo em vista poder estabelecer procedimentos de experimentação sem qualquer tipo de limites, cuja motivação e base justificadora utilizadas serão exatamente estas duas premissas, que acabam se retroalimentando de maneira perene: o caráter absoluto do valor saúde e a não limitação das possibilidades de alcance do conhecimento científico e do progresso técnico ${ }^{227}$.

Desse modo, ganha relevante papel em uma sociedade baseada no risco a aferição da probabilidade de sua ocorrência e a concretização dos critérios que sirvam à legitimação daquilo que pode ou não ser assumido, bem como de que maneira se dará essa eventual assunção. Ou seja, é necessário esclarecer que não basta uma análise das intenções, das finalidades, dos possíveis benefícios, sendo inexorável também que se faça um enfoque crítico dos meios utilizados.

\subsubsection{O processo decisório acerca da assunção dos riscos}

Políticas públicas primordialmente têm o papel de buscar regular as situações que envolvam riscos, ao implementar paradigmas aptos a permitir uma clara aferição do que seja ou não aceitável pela sociedade, quais possíveis consequências danosas possam ser assumidas e as contrapartidas exigidas no sentido da atenuação desses resultados.

Para a consecução da tarefa, a intervenção estatal se dá quer através de programas executivos, quer através da legislação e atividade jurisdicional. Há que se ressalvar que a correção de tal controle deve ser baseada em alicerces mais precisos de aferição dos riscos,

227 "Pelo contrário, o processo científico mesmo se desenvolve em inter-relação com o tecnológico, e isto no sentido intimamente mais vital: para alcançar seus próprios objetivos teóricos a ciência necessita de uma tecnologia cada vez mais refinada e fisicamente forte como ferramenta que produz a si mesma, é dizer, que incrementa a tecnologia. $\mathrm{O}$ que se encontra com esta ajuda será o ponto de partida de novos começos no campo prático, e este em seu conjunto, é dizer, a tecnologia trabalhando no mundo proporciona, por sua vez, à ciência, com suas experiências, um laboratório em grande escala, uma incubadora de novas perguntas para ela e assim sucessivamente em um circuito sem fim. (Más bien el proceso científico mismo se desarrolla en interrelación con el tecnológico, y esto en el sentido íntimamente más vital: para alcanzar sus proprios objetivos teóricos la ciencia necesita una tecnología cada vez más refinada y físicamente fuerte como herramienta que se produce sí misma, es decir, que encarga a la tecnología. Lo que encuentre con esta ayuda será el punto de partida de nuevos comienzos en el terreno práctico, y éste en su conjunto, es decir, la tecnología trabajando en el mundo, proporciona a su vez a la ciencia con sus experiencias un laboratorio a gran escala, una incubadora de nuevas preguntas para ella e así sucesivamente en un circuito sin fin)". Idem. p. 23. 
que devem ser informados por critérios $\operatorname{científicos}^{228}$ pré-definidos (ainda que não baseados na certeza ${ }^{229}$ como se verá mais adiante na análise do princípio da precaução), sem que se abandone, contudo, as repercussões sociais, jurídicas, econômicas e culturais que possam vir a ocorrer.

Mesmo nessa análise dos parâmetros científicos, imprescindível seja levado em conta a existência, nos dias atuais, de uma efetiva fusão entre ciência e técnica, ou seja entre teoria e prática. Pode-se estabelecer que a prática influencia a ciência, determinando os fins que esta deve perseguir. De modo concomitante, a produção de resultados pela ciência condiciona a própria realidade, em um processo circular e contínuo, que impulsiona, assim, o avanço técnico científico.

Devido à conjunção entre ciência e realidade, muito evidente no âmbito dos produtos médicos e farmacêuticos, pois que voltados à melhoria da saúde e prolongamento da vida, os resultados alcançados geram novas demandas por mais melhorias e maior prolongamento. Portanto, não se pode reconhecer, como no passado, que a atividade científica é neutra. Esse fator aliado à própria questão do financiamento da atividade científica por agentes econômicos e da sua crescente profissionalização tende a impelir que ela sofra questionamentos éticos ${ }^{230}$ e que, dessa forma, esteja sujeita a condições e

${ }^{228}$ Quando se refere a ciência ou científico no presente trabalho sem um qualificativo posterior, está se analisando as ciências exatas e biológicas. Alusões a outros ramos do conhecimento são expressamente explicitadas, como quando se trata das ciências jurídicas.

229 "Muitos dos novos riscos (nucleares ou de contaminações químicas, poluentes em alimentos, doenças em larga escala) escapam completamente às possibilidades humanas de percepção direta, $\mathrm{O}$ enfoque se dá cada vez mais em riscos que em alguns caos não produzirão efeitos durante o tempo de vida das pessoas afetadas, mas sim durante aquele de seus filhos. (Many of the newer risks (nuclear or chemical contaminations, pollutants in foodstuffs, diseases of civilization) completely escape human powers of direct perception. The focus is more and more on hazards that in some cases may not even take effect within the lifespans of those affected, but instead during those of their children; (...))". BECK, Ulrich. $o b$. cit. p. 27.

230 'Embora o 'esoterismo' dos múltiplos campos do saber tenha crescido e ainda siga neste processo - até a virtual inacessibilidade para todos, exceto aos experimentados em cada especialidade - a influência de seus mais remotos frutos teóricos é enorme: uma influência não, como outrora no melhor dos casos, sobre o pensamento e a opinião, senão sobre as condições e formas de vida. E com isto se inicia seriamente o tema 'ciência e ética'. Porque seja qual for a influência da ação humana sobre o mundo real, e que portanto afete potencialmente o bem-estar dos outros, está submetida à valoração moral e eventualmente a barreiras legais. (Aunque el 'esoterismo' de las multiplicadas ramas de lo saber ha aumentado aún y sigue aumentando - hasta la virtual inaccesibilidad para todos, excepto los consagrados en cada especialidad -, la influencia de sus más remotas prestaciones teóricas es enorme: una influencia no, con antaño en el mejor de los casos, sobre el pensamiento y la opinión, sino sobre las condiciones y formas de la vida. Y con esto empieza en serio el tema 'ciencia y ética'. Porque sea cual sea la influencia de la acción humana sobre el mundo real, y lo que por tanto afecte potencialmente al bienestar de otros, está sometido a la valoración moral y eventualmente a barreras legales)". JONAS, Hans. ob. cit. p. 67. "Nesse debate, podese observar opiniões de expertos e cientistas de que a utilização de novas técnicas ou atividades não 
regramentos.

Por conseguinte, baseado em tal premissa, é importante salientar que a ciência não se basta sozinha, serve como ponto de partida para uma análise mais profunda, reflexiva e relacional com os diferentes campos do conhecimento daquilo que possa ser tolerado de maneira um mínimo pacífica pela sociedade ${ }^{231}$, o que, aliás, já foi constatado quando da análise da bioética.

As ciências humanas, naturais e exatas devem caminhar juntas na avaliação dos riscos a serem suportados pela sociedade, não obstante se verifica nesse processo de tomada da decisão a existência de tensão contínua entre esses diversos campos de conhecimento, cujos pontos de partida são bastante diferentes entre si.

Como é constante observar, há uma tendência de que cada área procure preponderar sobre as demais. O importante, nesse aspecto, é que cada ramo de conhecimento, e os denominados "experts", dialoguem entre si e reconheçam a necessária complementariedade, apesar da oposição, a fim de que sirva para a construção de um consenso. Outra postura a ser assumida é a de estabelecer de maneira clara os parâmetros que estejam sendo considerados em cada processo de avaliação e decisão: "[a] preocupação científica com os riscos do avanço industrial na realidade baseia-se nas expectativas sociais e julgamentos de valor, assim como a discussão social e a percepção sobre os riscos depende dos argumentos científicos" ${ }^{232}$.

As ciências exatas e biológicas devem procurar oferecer os dados que sirvam como base objetiva para uma tomada de decisão que, se apoiada em um mínimo necessário em tais premissas, será mais legítima. Não se pode, no processo, pela constatação de que a ciência não é meramente descritiva e neutra, deixar de dar voz a posições minoritárias que, no limite, servirão como um alerta no sentido da necessidade de aprofundamento do estudo

importa risco nenhum e paralelamente pode-se escutar qualificados componentes da comunidade científica advertindo, com inúmeras razões, acerca dos perigos irreversíveis que elas podem importar para a agricultura, os seres humanos e ecossistemas. É evidente que se deve agregar que o nível de informação do qual dispõe a sociedade é inadequado e muitas vezes tendencioso. Ora, que as empresas industriais procurem sempre obter maiores benefícios não é nada surpreendente. Talvez o surpreendente seja que agora persigam fins humanitários, sociais ou políticos". HAMMERSCHMIDT, Denise. "O risco na sociedade contemporânea e o princípio da precaução no direito ambiental". In: Revista dos Tribunais, $\mathrm{n}^{\circ}$ 808, fev. 2003, São Paulo: Revista dos Tribunais, 2003. pp. 39-56. p. 40.

231 BECK, Ulrich. ob. cit. p. 24.

232 "(The scientific concern with the risks of industrial development in fact relies on social expectations and value judgments, just as the social discussion and perception of risks depend on scientific arguments). Idem. ob. cit. p. 30 . 
e da discussão acerca de determinada atividade.

De qualquer modo, nesta tarefa de permitir ou não determinada atividade frente aos riscos que ela possa acarretar, um eventual isolamento entre os campos do conhecimento impedirá a correta aferição dos riscos suportáveis frente aos benefícios possíveis, o que conduziria a um freio desnecessário ao avanço tecnológico ${ }^{233}$.

Todavia, apesar de ser normalmente recomendável que os critérios científicos orientem o processo decisório, estes não serão as únicas fontes informadoras da opção a ser tomada. Por também gerir-se como um processo político, a assunção dos riscos, ou a sua não permissão, poderá pautar-se em outros critérios que não os próprios da ciência. Ou seja, ainda que a ciência ofereça subsídios claros sobre os riscos envolvidos em certa atividade, ou mesmo que haja divergências nos diálogos anteriormente comentados, a assunção dos riscos pela sociedade não necessariamente deverá ser baseada em paradigmas puramente científicos ${ }^{234}$, podendo ser fruto da própria consciência da coletividade do que seja ou não tolerável. A própria concepção de risco, como algo não certo, mas provável, traz em seu bojo a constatação expendida.

Em comunidades altamente religiosas, por exemplo, é possível haver uma relutância na realização de pesquisas com manipulação genética, recomendando que as autoridades públicas implementem medidas restritivas em relação a tais experimentos, o que pode não ocorrer nas sociedades mais liberais, em que se abre a possibilidade até mesmo de que tais experimentações sejam incentivadas pelo Estado.

Assim, é necessário levar em conta que o risco é um modo de programação humana frente ao novo, ao desconhecido, tomando por base a preocupação com as consequências que tais novidades possam trazer a bens essenciais da pessoa humana e a sua existência, como à saúde, ao meio ambiente, à paz, à integridade psíquica, à moralidade ${ }^{235}$. Não se conhecem de maneira certa os prejuízos possíveis advindos de um

233 Pode-se observar que Hans Jonas, ao longo da obra anteriormente citada, é muito mais cauteloso acerca dos limites do avanço tecnológico, propugnando, de maneira resumida, que deve o homem adotar uma conduta de freio ao consumismo, devendo o desenvolvimento tecnológico diminuir seu ritmo, sob pena de destruirmos o planeta, ou legá-lo em péssima situação às gerações futuras.

234 "Os efeitos sociais das definições de risco não dependem, portanto, da validade científica destas. (The social effects of risk definitions is therefore not dependent on their scientific validity)”. BECK, Ulrich. ob. cit. p. 32 .

235 "O centro da consciência sobre o risco encontra-se não no presente, mas no futuro. Na sociedade de risco, o passado perde o poder de determinar o presente. Seu lugar é tomado pelo futuro, por algo, então, não existente, inventado, fictício como a 'causa' da experiência atual e modo de ação. Tornamo-nos ativos hoje com o objetivo de evitar, aliviar ou tomar medidas de precaução contra os problemas e crises do amanhã e 
processo de pesquisa clínica, não obstante nenhum envolvido deseje assumi-los caso venham a ocorrer.

Não é possível também deixar de atentar para um fato relevante: o de que a maior pobreza material e intelectual e a luta diária para o suprimento das necessidades básicas acarrete uma maior exposição a riscos e atividades danosas por suas populações, exatamente sob a justificativa de suprimento dessa carência.

Contudo, justamente por tais condições, tende a se formar uma cadeia em que a pobreza incentiva atividades com riscos que não seriam toleráveis frente aos benefícios potenciais em grupos sociais mais desenvolvidos. As situações de miséria ou carência econômica, visto que as pesquisas possam trazer algum tipo de benefício material a essas comunidades que seja apto a facilitar a subsistência, acabam justificando uma maior permissividade das autoridades e dos ordenamentos jurídicos frente a essas atividades.

Inclusive no âmbito da pesquisa clínica pode se verificar tal problemática no que tange aos projetos desenvolvidos abusivamente em países africanos, asiáticos ou da América latina e sob a chancela das autoridades locais, a pretexto da injeção de recursos, ainda que pequenos, nas fragilizadas economias. Outro condicionante à aceitabilidade das pesquisas é o fato de que oferecem, de maneira eticamente questionável, algum tipo de vantagem econômica direta para os "voluntários"

Enfim, o cada vez mais rápido avanço tecnológico e a expansão das atividades econômicas produtivas, bem como a importância e dispersão dos bens atingidos por essas atividades, sejam a saúde ou o meio ambiente, fazem nascer, como se frisou, um maior temor por parte da sociedade no que se refere às consequências de tal fenômeno. Isso tende a revelar um aprofundamento da ideia de riscos e a necessidade de controle do surgimento destes e da atenuação dos seus possíveis efeitos.

Nota-se que a eventual concretização dos riscos afeta a todos de maneira direta, assim, com tal premissa, o gerenciamento dos riscos se constrói a partir de uma busca

do depois do amanhã - ou não fazer isto. (The center of risk consciousness lies not in the present, but in the future. In the risk society, the past loses the power to determine the present. Its place is taken by the future, thus, something non-existent, invented, fictive as the 'cause' of current experience and action. We become active today in order to prevent, alleviate or take precautions against the problems and crises of tomorrow and the day after tomorrow - or not to do so)". Idem. p. 34.

236 'Há uma sistemática 'atração' entre a pobreza extrema e o risco extremo (...). Em escala internacional é enfaticamente verdadeiro que a miséria material e a cegueira a riscos coincidam. (There is a systematic 'attraction' between extreme poverty and extreme risk (...). On the international scale it is emphatically true that material misery and blindness to hazards coincide)". Ibidem. p. 41 
constante do diálogo entre a completude dos integrantes da sociedade. Não se pode aceitar o monopólio da ciência sobre a avaliação dos riscos toleráveis. Esse é um processo conjunto de tomada de decisão, em que, na verdade, se alguém necessita ceder frente à constatação social, ética, jurídica ou política sobre a aceitabilidade de riscos é a própria percepção científica ${ }^{237}$.

Logo, não há razão para que se mantenham as ciências naturais e exatas em um patamar de monopólio do saber, intocáveis e inquestionáveis ${ }^{238}$. Pelo contrário, a experiência da sociedade absolutamente crente na ciência demonstrou ser uma catástrofe humanitária, como aquela do nazismo. Essa falibilidade da ciência é que conduz a legitimação das contestações sociais frente aos resultados por ela alcançados, possibilitando um processo decisório complexo, relacional e interdisciplinar frente aos riscos.

É fato que as pessoas, quando em face dos riscos, encontram-se em uma situação de impotência, pois a avaliação da positividade ou negatividade futura de uma determinada situação foge ao âmbito de atuação da percepção sensorial e da própria inteligência do indivíduo. Torna-se necessário buscar em fontes externas as informações daquilo que representa ou não um considerável risco:

[n]este sentido, posições de risco criam dependências que são desconhecidas em situações de classe; as partes afetadas estão se tornando incapazes em matéria de suas próprias aflições. Elas perdem uma parcela essencial de sua soberania cognitiva. O prejuízo, a ameaça, o hostil encontra-se em todo lugar, mas a tarefa de definição do negativo ou positivo está além do próprio poder de julgamento, estando reservada às suposições de produtores externos de conhecimento ${ }^{239}$.

Por se tratarem os riscos de uma construção baseada em verossimilhança ${ }^{240}$ e não

237 “A sociedade de risco está, nestes termos, também na ciência, na mídia e na sociedade da informação. (The risk society is in this sense also the science, media and information society)". Idem ibidem. p. 46

238 "A avaliação dos riscos num contexto de incerteza é uma questão política e jurídica e não tão somente uma problemática de método e de ontologia científica”. HERMITTE, Marie-Angelè; DAVID, Virginie. "Avaliação dos riscos e princípio da precaução". In: VARELLA, Marcelo Dias; PLATIAU, Ana Flávia Barros (coords.). Princípio da precaução. Belo Horizonte: Del Rey, 2004. pp. 93-155. p. 95.

239 "(In this way, risk positions create dependencies which are unknown in class situations; the affected parties are becoming incompetent in matters of their own affliction. They lose an essential part of their cognitive sovereignty. The harmful, threatening, inimical lies in wait everywhere, but whether it is inimical or friendly is beyond one's own power of judgment, is reserved for the assumptions of external knowledge producers)". BECK, Ulrich. ob. cit. p. 54.

240 “Já o princípio da constitucional da precaução, também diretamente aplicável, traduz-se, nas relações 
em concreção com base em resultados negativos pré-existentes, é essencial que novas atividades e tecnologias ligadas a interesses sensíveis e com efeitos ainda desconhecidos ${ }^{241}$ sejam submetidas a uma prévia e bem informada avaliação acerca das probabilidades de produção de eventos danosos, ou seja, dos riscos envolvidos e de quem possa ser afetado ao longo do processo.

Por outro lado, isto também significa que todas as decisões sobre riscos e perigos submetidas à produção de conhecimento não são nunca questões meramente acerca do conteúdo deste (inquirições, hipóteses, métodos, procedimentos, valores aceitos etc.). Elas são ao mesmo tempo sobre quem é afetado, a extensão e tipo de risco, os elementos da ameaça, a população referida, efeitos retardados, medidas a serem tomadas, responsabilidades e reinvindicações de compensação ${ }^{242}$.

Inegável que o caráter fluido de definição dos riscos, que tem como base o temor

frente ao desconhecido, ou conhecido de maneira apenas incipiente, possa provocar nas pessoas uma contrarreação de negação desses riscos.

Comum, desse modo, surgirem manifestações radicais contrárias àqueles que procuram construir a ideia de risco na sociedade, taxando-os de apocalípticos, ou mesmo denominando suas teorizações de devaneios injustificáveis e incomprovados ${ }^{243}$.

administrativas ambientais (mas não só), como o dever de o Estado motivadamente evitar, nos limites de suas atribuições e possibilidades orçamentárias, a produção de evento que supõe danosos, em face da fundada convicção (juízo de verossimilhança) quanto ao risco de, não sendo interrompido tempestivamente o nexo de causalidade, ocorrer um prejuízo desproporcional, isto é, manifestamente superior aos custos da eventual atividade interventiva". FREITAS, Juarez. "Princípio da precaução: vedação de excesso e de inoperância". In: Interesse Público. Ano VII, no 35, Porto Alegre: Notadez Informação, 2006. pp. 33-48. p. 36.

241 "O incerto não é algo necessariamente inexistente. Ele pode não estar bem definido. Ou não ter suas dimensões ou seu peso ainda claramente apontados. $\mathrm{O}$ incerto pode ser uma hipótese, algo que não foi ainda verificado ou não foi constatado. Nem por isso, o incerto deve ser descartado, de imediato. O fato de o incerto não ser conhecido ou de não ser entendido aconselha que ele seja avaliado ou pesquisado". MACHADO, Paulo Affonso Leme. "O princípio da precaução e a avaliação de riscos". In: Revista dos Tribunais. v. 856, fev. 2007, São Paulo: Revista dos Tribunais, 2007. pp. 35-50. p. 37.

242 "(On the other hand, this also means that all decisions on the risk and hazards of civilization falling within the compass of knowledge production are never just questions of the substance of knowledge (inquiries, hypotheses, methods, procedures, acceptable values etc.). They are at the same time also decisions on who is afflicted, the extent and type of hazard, the elements of the threat, the population concerned, delayed effects, measures to be taken, those responsible, and claims for compensation)". BECK, Ulrich. ob. cit. p. 54.

243 'Os cientistas insistem na questão da 'qualidade' de seu trabalho e mantém seus padrões teóricos e metodológicos elevados com a finalidade de assegurar suas carreiras e seu sucesso material. A partir de tal constatação, uma lógica peculiar resulta no seu trato com os riscos. A defesa de que ligações não foram verificadas pode parecer boa para um cientista e louvável em geral. Quando se lida com riscos, o contrário é ocasionado para as vítimas; os riscos são multiplicados. Aqui se preocupa com os perigos que devem ser evitados, cuja probabilidade, ainda que baixa, tem um efeito ameaçador. Se o reconhecimento 
A partir de tal raciocínio, é preciso entender que a contestação dos riscos é desejável para o estabelecimento de parâmetros mais seguros às novas tecnologias. Nesse sentido, deve a determinação de riscos representar um constante processo dialético e argumentativo, com o intuito de atingir um balanceamento entre a utilidade que essas novas tecnologias possam trazer, e os perigos que advenham delas, especialmente aos denominados direitos da personalidade.

Todavia, a negação dos riscos não contribui para esse processo, haja vista que, assim como seu contraponto, o do total medo e paralisia frente a esses perigos, possa provocar uma cisão entre os grupos e não um esforço comum de ponderação e diálogo.

Resta, por consequência, a certeza de que a ciência não foi capaz de resolver todos os problemas surgidos a partir dos avanços que ela própria proporcionou. Isso significa que a ciência, e o seu método tradicional de quebra de tabus e construções racionais baseadas em cálculos exatos ou observações empíricas, não pode por si só, de maneira isolada, afastar os danos irreversíveis a bens deveras sensíveis para a sociedade como um todo, e, individualmente considerados, a determinada pessoa. Aliás, é conclusão similar àquela empreendida quando da análise da importância da bioética e do biodireito.

Portanto, as ciências naturais e exatas passam a ocupar um outro papel, baseado em uma reflexão crítica e conjunta com membros de outros campos de conhecimento, com a sociedade e com o Poder Político, das consequências que os avanços científicos, sobretudo na área médica, porque objeto do presente trabalho, possam acarretar ${ }^{244}$.

de um risco é negado com base em um 'não claro' situação informativa, isto significa que as necessária medidas protetivas são negligenciadas e o perigo cresce. (Scientists insist on the 'quality' of their work and keep their theoretical and methodological standards high in order to assure their carriers and material success. From that very fact, a peculiar non-logic results in their dealing with the risks. The insistence that connections are not established may look good for a scientist and be praiseworthy in general. When dealing with risks, the contrary is the case for the victims; they multiply the risks. One is concerned here with dangers to be avoided, which even at low probability have a threatening effect. If the recognition of a risk is denied on the basis of an 'unclear' state of information, this meant that the necessary counteractions are neglected and the danger grows)". Idem. p. 62.

244 "É crescentemente notável que as ciências da engenharia estão diante de um dilema histórico: elas podem continuar a pensar e trabalhar com os desgastados modos do século XIX. Então, elas irão misturar os problemas da sociedade de risco com aqueles da nascente sociedade industrial. Ou elas podem encarar os desafios de um genuíno e preventivo gerenciamento dos riscos. Assim, elas devem repensar e mudar suas próprias concepções de racionalidade, conhecimento e prática, bem como as estruturas institucionais nas quais estas são postas em exercício. (It is increasingly apparent that the engineering sciences face a historic turning point: they can continue to think and work in the worn-out ways of the nineteenth century. Then they will confuse the problems of the risk society with those of early industrial society. Or they can face the challenges of a genuine, preventive management of risks. Then they must rethink and change their own conceptions of rationality, knowledge and practice, as well as the institutional structures in which these are put to work)". Ibidem. p. 71. 
A ideia de riscos norteia tal cenário, em conformidade com o que o conteúdo e a aceitabilidade destes sejam determinados a partir de um processo argumentativo que envolva os resultados científicos produzidos sobre determinados fenômenos, considerando os benefícios e as potencialidades danosas.

De acordo com o estado da técnica, e a definição social e política sobre a aceitação dos resultados alcançados pelo processo acima delineado como aptos ou não à aferição da segurança de determinada nova tecnologia, é que devem ser tomadas as pertinentes decisões, baseadas na precaução. Desse modo, estabelecer-se-ia um controle mais rígido sobre as técnicas e atividades avaliadas, até mesmo com a proibição ou restrição ampla de sua utilização.

A ciência deve aceitar a sua falibilidade e internalizar no processo de construção de dados a imprevisibilidade e a possibilidade de erros, para que se construa uma ideia mais verdadeira e crítica dos riscos ${ }^{245}$.

A crítica à ciência pode ser uma importante força para a sua transformação, na proporção em que faça surgir a necessidade de buscar uma resposta adequada a estas censuras, quer as confirmando, quer as negando. Não há uma negação absoluta da ciência, apenas uma relativização de resultados que apresenta, através da dúvida, da contestação do senso-comum.

Trata-se de uma relação dialética em que a ciência cria novas tecnologias e, frente ao temor das consequências dessas, outros setores da mesma área científica, a sociedade, o Estado e os demais campos de conhecimento procedem a um questionamento da potencialidade lesiva de tais invenções e mesmo do processo de desenvolvimento.

245 “Com boas razões alguém pode sustentar que a história das ciências foi sempre menos a história da aquisição do conhecimento, do que dos erros e lapsos práticos. Isto reflete a razão pela qual o 'conhecimento', as 'explicações', e a 'sugestão de soluções' práticas são contraditórias através dos tempos, em diferentes lugares, escolas de pensamento, culturas e assim por diante. Esta necessidade não implica qualquer perda de credibilidade da aclamada racionalidade científica, na medida em que as ciências podem lidar satisfatoriamente com seus enganos, erros e críticas às suas consequencias práticas essencialmente com a própria ciência. Nesse sentido, elas mantém o seu monopólio acerca da necessária racionalidade contra a esfera do público não especializado, por um lado, e de outro elas preparam um terreno disciplinado para discussões críticas . (With good reasons one can proceed from the perspective that the history of sciences was always less a history of the acquisition of knowledge than one of mistakes and practical lapses. That is why scientific 'knowledge', 'explanations', and practical 'suggested solutions' contradict each other diametrically over time, at different places, in different schools of thought, cultures and so on. This need not imply any loss in the credibility of scientific rationality claims so long as the sciences can succeed in handling the mistakes, errors and criticism of their practical consequences essentially within science. In that way they maintain their monopoly claim to rationality against the nonspecialized public sphere on the one hand, and on the other they prepare a forum for critical discussions within the discipline". Idem ibidem. p. 159. 
Com tal movimento, é possível ofertar um maior controle político e social. Gerase, a partir disso, a necessidade de o campo científico se debruçar mais detidamente sobre a plausibilidade de ocorrência dos riscos levantados como possíveis, com intuito de se alcançarem novos dados que informarão o constante processo de renovação da escolha sobre a conveniência da utilização dessas novas tecnologias. Tal processo deve sempre se atualizar, afinal possui em sua gênese a incerteza.

\subsubsection{O princípio da precaução: definição e diferenças com o princípio da prevenção}

O princípio da precaução, muito presente nas questões ligadas ao meio-ambiente, alastrou-se por todas as áreas da atividade humana, de acordo com o desenvolvimento tecnológico e científico. Nesse sentido, a criação de novos produtos, métodos, aparelhos, veículos etc. possibilitou ao homem o alcance de resultados até então inesperados e também redundou, por óbvio, na aproximação do desconhecido, conceito intimamente ligado, como visto anteriormente, à ideia de risco. Por seu lado, "o princípio da precaução aparece para tentar evitar ou diminuir os males da 'sociedade de risco'. Portanto, sempre que estivermos diante da incerteza sobre danos possíveis, o princípio da precaução deverá atuar como instrumento de gerenciamento dessa incerteza"246.

Esse princípio teve sua formulação iniciada no Direito Ambiental. O primeiro tratado que faz referência ao termo, relativo à proteção da camada de ozônio, é a Convenção de Viena de 1985, a qual estabelece o reconhecimento da necessidade de "medidas de precaução"247.

$\mathrm{Na}$ verdade, a ideia já era paulatinamente difundida, como se percebe na Declaração Ministerial da Conferência Internacional para a proteção do Mar do Norte, 1984, que em seu preâmbulo

refletiu a conscientização de que os Estados 'não devem esperar por provas de efeitos prejudiciais antes de entrarem em ação' uma vez que os danos ao ambiente marinho podem ser irreversíveis ou apenas

LOPEZ, Teresa Ancona. ob. cit. p. 86 (grifo da autora).

247 SANDS, Philippe. "O princípio da precaução". In: VARELLA, Marcelo Dias; PLATIAU, Ana Flávia Barros (coords.). Principio da precaução. Belo Horizonte: Del Rey, 2004. pp. 29-46. p. 31. 
remediáveis após longos períodos de tempo, e as medidas corretivas têm alto custo. Isso introduz a ideia de que a ação de precaução pode ser justificada por questões econômicas ${ }^{248}$.

Há que se destacar também que o princípio foi reafirmado várias vezes em tratados posteriores, ainda que não tenha sido referenciado nominalmente, estando presente, no entanto, o seu conteúdo nesses instrumentos. O percurso histórico da construção do princípio da precaução culmina na Declaração do Rio de 1992, que hoje é reconhecida, majoritariamente, como aquela que melhor expressa o sentido específico do termo, em seu princípio 15 .

De acordo com tal formulação, a ausência de uma ligação comprovada entre uma determinada conduta e a produção de prejuízos não pode ser apta a elidir a responsabilidade quanto à tomada de medidas que visem a afastar ou reduzir a probabilidade de ocorrência desses eventuais e possíveis danos ${ }^{249}$.

Interessante é diferenciar a precaução do conceito da prevenção ${ }^{250}$. Ambos se relacionam a um agir com prudência e se vinculam à ideia de antecipação aos danos. Além disso, cuidam das medidas que se mostrem necessárias a evitar a ocorrência dos prejuízos, fugindo do mero ressarcimento desses quando já concretizados.

No caso da prevenção, os danos que serão produzidos já estão cientificamente provados, cabendo tomar medidas diretas a evitar a eclosão dos prejuízos. As relações de causa e efeito são, pois, bem conhecidas, o que permite uma maior efetividade e precisão das condutas a serem tomadas e que estejam aptas a afastar ou mitigar a possibilidade de

248 Idem. p.31.

${ }^{249}$ Cass Sustein, denomina esta conceituação como versão fraca do princípio da precaução. Para este autor, “[a]s versões fracas do princípio da precaução declaram um truísmo o que é incontroverso e necessário somente para combater perplexidade pública ou demandas de interesse próprio de grupos privados postulando evidências inequívocas de danos, o que nenhuma sociedade racional precisa. Esta função não deve ser banalizada", e prossegue, aduzindo que "[p]ara a versão fraca, a principal tarefa atual é encontrar maneiras de ajustar a extensão da evidência com a extensão da resposta. Evidência fraca de dano, por exemplo, deve simplesmente sustentar pesquisa mais aprofundada, ao passo que evidência forte deve dar suporte a esclarecimento público do risco e evidência ainda mais forte deve fundamentar controles regulatórios. Um calibre mais refinado de evidências para responder seria um caminho importante para implementar a versão fraca”. ob. cit. pp. 132-133. Já quanto ás versões fortes do princípio da precaução, cuja formulação é criticada no texto em questão, define o autor que "sob o princípio da precaução, como o entendo, a prova do limiar [entre a atividade e o dano] é mínima e, uma vez encontrada, há algo como uma presunção em favor de controles regulatórios rígidos”. ob. cit. p. 132. Como veremos adiante, tal ideia liga-se àquela de "precaução na precaução".

250 "Enquanto o princípio da prevenção pode ser encontrado em tratados internacionais ambientais e em outros atos internacionais, pelo menos desde os anos 1930, o princípio da precaução começou a constar nos instrumentos legais internacionais em meados dos anos 1980". SANDS, Philippe. ob. cit. p. 29. 
produção de eventuais prejuízos.

Por outro lado, a precaução se liga aos danos cuja ocorrência não é absolutamente certa $^{251}$. Nota-se que a ciência aqui pode oferecer indícios de que determinadas atividades podem levar a eventos maléficos, não sendo imprescindível, entretanto, como se afirmou acerca da definição da ideia de riscos, que estes representem o fator único condicionante do processo de aplicação do princípio da precaução.

Nas palavras de Teresa Ancona Lopez, reproduzindo as ideias de Viney e Kourilsky,

as probabilidades não são da mesma natureza: no caso da precaução, trata-se da probabilidade de que a hipótese esteja certa; no caso da prevenção, o perigo é estabelecido e se trata de probabilidade de acidente. Os riscos potenciais, a despeito do seu caráter hipotético, podem ter uma probabilidade de realização elevada. Na prática, a precaução pode estar compreendida como prolongamento dos métodos de prevenção aplicados aos riscos incertos ${ }^{252}$.

A experiência prática mostrou que não se poderia esperar, para a tomada de medidas destinadas a evitar prejuízos consideráveis, que estes fossem concretamente conhecidos de acordo com dados cientificamente comprovados. Era preciso adotar certas condutas, frente aos novos avanços científicos, antes que a própria ciência conhecesse de maneira real as consequências eventualmente danosas, exatamente pela importância e extensão dos possíveis prejuízos que poderiam advir. A espera poderia significar a produção de resultados negativos irreparáveis ${ }^{253}$.

251 “[S]e estivéssemos tratando de riscos conhecidos, poderíamos exigir a prova antecipada da eficácia das medidas a serem tomadas para preveni-los (sendo essa a essência do princípio da prevenção). Ao tratarmos de riscos sobre os quais não há certeza científica, será praticamente impossível afirmar antecipadamente quais serão as medidas eficazes. Esse grau de incerteza é inerente ao princípio da precaução, mas como ressaltado por Kourilsky e Viney, incerteza não é sinônimo de desconhecimento. A análise dos riscos deve preceder as crises ao invés de seguir-se a elas e, para tanto, faz-se necessário conhecimento profundo e continuado". BOITEUX, Elza Antônia Pereira Cunha; BOITEUX, Fernando Netto. Poluição eletromagnética e meio ambiente: o princípio da precaução. Porto Alegre: Sergio Antonio Fabris Ed., 2008. p 179. Em sentido complementar: "[e]nfim, dessa comparação surge uma diferença que deve modular no debate social de nossos dias: enquanto a prevenção é um assunto de especialistas confiado em seus saberes, a precaução é um assunto que compete à sociedade em seu conjunto e deve ser gestionado em seu seio para orientar a tomada de decisões políticas sobre assuntos de relevância fundamental". HAMMERSCHMIDT, Denise. ob. cit. p. 49.

252 ob. cit. p. 90 (grifo da autora).

253 "O reconhecimento de que a prevenção dos riscos conhecidos e quantificados era insuficiente para prevenir a ocorrência de danos irreparáveis veio a originar o princípio da precaução, de maior amplitude". BOITEUX, Elza Antônia Pereira Cunha; BOITEUX, Fernando Netto. ob. cit. p. 144 
Desse modo, passou-se a considerar a ideia, fazendo um paralelo com o processo civil, de que a verossimilhança dos prejuízos seria suficiente para impor medidas restritivas cuja função seria proteger, de maneira mais ampla, a sociedade contra os riscos desconhecidos, porém, de certa forma, possíveis de acontecer. Enquanto a prevenção basear-se-ia em um juízo de cognição exauriente, a precaução seria tomada a partir de um juízo sumário. Nessa comparação, a prevenção seria o processo de conhecimento; a precaução, o processo cautelar.

\subsubsection{A aplicação do princípio da precaução no processo decisório sobre a assunção de riscos}

Convém ressaltar que o princípio da precaução deve ser utilizado de maneira cuidadosa ("precaução da precaução"254), não radical, o que sempre levaria em conta os princípios da razoabilidade e proporcionalidade.

Em particular atenção ao nosso trabalho, cumpre mencionar a crítica ao princípio da precaução relativa ao fato de que esse paralisaria a evolução científica ${ }^{255}$. Aqui não se concorda com tal premissa, já que a forma de aplicação deste padrão deve ser temperada, ou seja, tendendo a se conciliar com a necessidade de avanços possibilitados pelo progresso científico.

Solange Telles da Silva, na mesma esteira, defende que a aplicação do princípio

${ }^{254}$ Cf. LOPEZ, Teresa Ancona. ob. cit.

${ }^{255}$ Cass Sustein, na obra citada, atacando o que ele considera a versão forte do princípio da precaução, afirma que "o problema mais sério com a versão forte do princípio da precaução é que ele não oferece nenhum direcionamento - não que ela seja equivocada, mas ela proíbe todas as formas de ação, incluindo inação". p. 136. E para reforçar tal assertiva, analisa alguns casos concretos, como aquele que envolve o "drug lag" (atraso na aprovação de medicamentos), causado em decorrência de uma abordagem demasiadamente precavida para a introdução de noivos medicamentos e drogas no mercado. Se um governo sustenta tal abordagem, ele deve proteger pessoas contra danos decorrentes de drogas testadas inadequadamente, mas ele também impedirá pessoas de receber benefícios potenciais daquelas drogas. É 'precaução' demandar testes extensivos antes de introduzir ao mercado ou é fazer o contrário". p. 138. De fato, a noção corrente de que, no caso da existência de um mínimo patamar de riscos, o ônus da prova de acerca da não ocorrência destes recai naquele que deseja desenvolver determinada atividade não pode ser aceito de maneira generalizada, devendo-se a precaução ser aplicada com prudência, norteando os órgãos decisórios para que instituam medidas adequadas tanto à probabilidade de riscos, os danos que podem surgir, e os fins e benefícios almejados por aquela sociedade. O princípio da precaução, nessa análise, demanda que a avaliação dos riscos seja efetuada de maneira ponderada, e não baseada no medo insustentável. A regulação, conforme defendido nas linhas posteriores, deve ser proporcional. 
da precaução deve ser efetuada de acordo com a proporcionalidade "lato sensu", que dependeria, de acordo com sua visão, de uma avaliação da adequação, da necessidade e da proporcionalidade em sentido estrito de determinada medida, propugnando que

\begin{abstract}
[i]sso significa que o primeiro exame deve ser o da adequação, ou seja, devem-se buscar meios para que os riscos sejam minimizados. A avaliação científica fornece uma base para que o princípio da precaução venha a ser implementado, pois são as conclusões dessa avaliação que determinarão o nível adequado de proteção. E mesmo que não haja prova científica da existência de uma relação de causa e efeito, os atores políticos devem avaliar as consequências potenciais da falta de uma determinada ação sobre o meio ambiente e a saúde humana. A necessidade de atuação do poder público deve ser pautada em um exame comparativo. E, finalmente, o exame da proporcionalidade em sentido estrito deve pautar-se na dimensão do 'peso', isto é, do 'valor' dos princípios que venham a colidir. Deve-se ponderar entre os objetivos a serem alcançados por determinada atividade e as escalas do risco, estabelecendo-se uma ordem de prioridades em função das incertezas que caracterizam o próprio princípio da precaução. É evidente que serão os valores da sociedade que determinarão a ordem de prioridades e, neste sentido, a proteção do meio ambiente e da saúde humana, e da vida, em última análise, deve ser colocada como valor absoluto, pois a vida não tem preço $^{256}$.
\end{abstract}

Não se pode olvidar que o princípio da precaução seja considerado como fruto de uma sociedade baseada na prudência frente aos riscos desconhecidos e potencializados pelo desenvolvimento tecnológico. A saber, prudência frente aos riscos, para evitar a produção de danos contra as pessoas, cada vez atingidas em maior número e de modo negativo, no atual contexto social de massificação das relações.

Exatamente por tal fato, procura-se evitar, de maneira mais acurada, a produção de prejuízos que simplesmente a reparação destes cuja repercussão econômica é dificilmente aferível "a priori" e suportada, de acordo com os parâmetros do mercado capitalista, por toda a sociedade.

Todavia, não é apenas o fator econômico que explica a existência do princípio da precaução. $\mathrm{Na}$ realidade, em muitas áreas, como a relativa ao presente trabalho, é no respeito ao ser humano, à sua autonomia e vida saudável, como espécie e como indivíduo, como finalidade primordial de proteção do Direito, que se pauta o conteúdo do princípio.

\footnotetext{
${ }^{256}$ SILVA, Solange Teles da. "Princípio da precaução: uma nova postura em face dos riscos e incertezas científicas". In: VARELLA, Marcelo Dias; PLATIAU, Ana Flávia Barros (coords.). Princípio da precaução. Belo Horizonte: Del Rey, 2004. pp. 75- 92. p. 88.
} 
A necessidade de promoção da existência digna da pessoa, preservando-se a sua integridade física e moral, impõe um dever geral de cuidado de cada um frente aos outros, traduzidos por duas palavras bastante em voga: a solidariedade e a segurança, previstas em diversos textos normativos e resumidas dentro do princípio da precaução.

Defende-se, portanto, com essa afirmação, que não basta confinar ao âmbito da ética ou da moral tal princípio, em razão de, no Estado de Direito, ser imprescindível que este seja introduzido no sistema jurídico, a fim de que ganhem real força obrigatória os deveres por ele impostos e já tratados.

Além disso, a afirmação principiológica, apenas, não é suficiente para que se cumpra a tarefa de regulação efetiva do caso concreto, e imposição de condutas que permitam proteger o ser humano contra os riscos desconhecidos, ou perigos concretos. Estes princípios devem ser acompanhados de edições de regras, já que, de maneira sucinta, estas se complementam de maneira circular, cada qual com suas funções, mediatas e imediatas, para que se dê eficácia ao Direito ${ }^{257}$.

A adoção da precaução é imposta a todos os atores sociais, privados ou públicos, mediante a imposição de condutas ou de atribuição de deveres fiscalizatórios e decisórios:

[e]ssa atitude de prudência como virtude que engloba a prevenção e a precaução, deve ser obrigatória para seus atores. Os atores, que detêm o poder de decisão, podem ser, algumas vezes, os representantes do Ministério Público, que, tendo como instrumento a ação civil pública, podem bloquear certas atividades ou proibir produtos que pareçam apresentar riscos capazes de causar danos coletivos. A perícia nesses casos é cabal, pois as consequências sociais serão catastróficas em alguns casos. Esses representantes do Poder Público devem socorrer-se das opiniões científicas e técnicas para formar convicção, porquanto não possuem formação para esse tipo de avaliação. Acrescente-se a isso a atitude de prudência, da qual já falamos. Da mesma forma, deverão proceder todos os órgãos de decisão dentro da Administração Pública direta e indireta, sempre no uso dos princípios da razoabilidade e proporcionalidade $^{258}$.

257 “[C]omo as regras consistem em normas imediatamente descritivas e mediatamente finalísticas, a justificação da decisão de interpretação será feita mediante avaliação de concordância entre a construção conceitual dos fatos e a construção conceitual da norma. Como os princípios se constituem em normas imediatamente finalísticas e mediatamente de conduta, a justificativa da decisão de interpretação será feita mediante avaliação dos efeitos da conduta havida como meio necessário à promoção de um estado de coisas posto pela norma como ideal a ser atingido". ÁVILA, Humberto Bergmann. Teoria dos princípios: da definição à aplicação dos princípios. $5^{\mathrm{a}}$ ed. São Paulo: Malheiros, 2006. p.75.

258 LOPEZ, Teresa Ancona. ob. cit. pp. 116-117. 
A realização de determinadas atividades que se enquadrem naquelas geradoras de riscos, conforme a conceituação delineada deve ser submetida a critérios especiais de aferição, em que a tônica maior seja a aplicação do princípio da precaução, sempre com a devida proporcionalidade ${ }^{259}$.

Os princípios da motivação e da proporcionalidade é que irão possibilitar a constatação de que as medidas interventivas de precaução ou prevenção estejam ou não de acordo, considerados os pressupostos de fato e de direito, com a função a que se proponham e com o ordenamento, de um modo geral, sem ausência ou excesso de diligência $^{260}$.

Não se pode estabelecer qualquer tipo de apriorismo na concretização do princípio da precaução, sendo necessário que a análise seja feita sobre cada caso, levando em conta suas peculiaridades, probabilidades dos prejuízos, bens protegidos, riscos associados à inação. Necessário, também, que a avaliação em tela evite que os benefícios potenciais de determinada atividade sejam ignorados apenas pelo fato de que a ela estejam associados alguns riscos.

Outrossim, inexorável a motivação precisa de determinada escolha a qual permita o controle social do processo decisório, que será legítimo desde que reflita uma correta ponderação entre adequação e proporcionalidade dos meios aos fins. Tal postura possibilita, também, a contínua revisão da opção exercida naquele determinado momento, com os dados até então disponíveis. A aplicação de determinada medida, tendo em vista a ideia de riscos, é pautada na precariedade, na constante possibilidade de revisão, exatamente porque, como mencionado, a incerteza é subjacente a este processo

\footnotetext{
259 "A aplicação da abordagem da precaução, por sua vez, exige que os Estados tomem ações antes de tais crises, isso é, onde há uma prova prima facie de que tal crise possa ocorrer. Aqueles em favor de continuar a atividade em questão têm agora que provar cientificamente que tal crise não existe e que a atividade em questão não leva à crise". WOLFRUM, Rüdiger. "O princípio da precaução". In: VARELLA Marcelo Dias; PLATIAU; Ana Flávia Barros (coords.). Princípio da precaução. Belo Horizonte: Del Rey, 2004. pp. 13-28. p. 27. Não se concorda com tal afirmação, pelos motivos já expostos, sendo que se posiciona conforme Paulo Affonso Leme Machado, ao afirmar que "[e]ntre uma posição mais radical (que preconiza a completa inversão da prova, de exclusiva responsabilidade de quem decide a questão) e uma posição minimalista (que entende que o princípio da precaução não inverte a carga da prova ) apresentam uma posição intermediária que subordina a implementação do princípio da precaução ao anunciado de uma hipótese de risco cientificamente crível, que seja admitida como plausível por uma parte significativa da comunidade científica no momento da tomada de decisão. Essa posição intermediária deixa ao juiz a possibilidade de repartir o ônus da prova em função da verossimilhança e dos meios de que cada uma das partes disponha para trazer essa prova". ob. cit. p. 46.

${ }^{260}$ FREITAS, Juarez. ob. cit. p. 38.
} 
decisório $^{261}$.

Traçadas essas considerações, reforçam-se alguns posicionamentos defendidos anteriormente no correr desta dissertação. Exatamente, a precaução ante os riscos, associada à preservação do melhor interesse da criança e do adolescente de modo prioritário, impõe a constatação de que a participação dos menores em pesquisas clínicas seja cercada de inúmeras cautelas, como a consideração da vontade dos infantes, a participação do Ministério Público junto aos comitês de ética, e a regulamentação desses experimentos por intermédio de Lei formal, amplamente discutida pela sociedade, sem se negar o acesso, em última instância, ao Poder Judiciário.

Portanto, ainda que se chegue a situações-limite em que a aplicação do princípio da precaução não se mostre tão clara, a ponto de permitir um seguro e determinado caminho, esse princípio deverá servir, ao menos, como orientação inicial de que decisões a serem tomadas em casos mais complexos e intrincados sejam efetuadas de maneira reflexiva, participativa, com uma efetiva ponderação entre riscos e benefícios. E é precipuamente nesse sentido que deve caminhar a regulação da pesquisa clinica, ou seja, para que o processo de escolha sobre sua pertinência, em geral ou no caso individual, torne-se cada vez mais claro, motivado e proporcional, e não instrumento do medo excessivo ou da total desconsideração dos riscos envolvidos, sob o pretexto da impossibilidade de imposição de freios ao avanço científico e tecnológico.

261 “A significação ética do gerenciamento dos riscos é garantida por três fatores: a otimização que responde à necessidade de reduzir ao mínimo possível os riscos (dimensão objetiva do risco), a transparência que responde à necessidade ética de se levar em conta a aceitação cultural do risco (dimensão subjetiva do risco), e, finalmente, o controle dos procedimentos de otimização e transparência. (La significatività etica del risk management viene garantita da tre fattori: l'ottimizzazione che risponde alla necessità etica di ridurre il possibile il rischio (dimensione oggettiva del rischio), la trasparenza che risponde alla necessità etica di tenere conto dell'accettazione culturale del rischio (dimensione soggettiva del rischio), e infine il controllo sulle procedure di ottimizzazione e trasparenza)". MELE, Vincenza. "Bioetica della differenza nell'accettazione delle biotecnologie: diversità di paradigmi scientifici e/o di culturale". In: COMPAGNONI, Francesco; D'AGOSTINO, Francesco (edd). Il confronto interculturale: dibattiti bioetici e pratiche giuridiche. Bioetica, diritti umani e multietnicità. Milano: San Paolo, 2003. pp. 318335. p. 334. 


\subsection{A responsabilidade civil quanto aos danos materiais e morais sofridos por crianças e adolescentes sujeitos de pesquisa clínica}

\subsubsection{Da responsabilidade civil nas atividades médicas}

\subsubsection{Considerações gerais}

No atual contexto social e jurídico, a responsabilização de profissionais de saúde quando as atividades desenvolvidas por eles acarretarem prejuízos ao paciente é possível e amplamente aceita.

Todavia, tal cenário já foi bastante diferente em um passado não tão distante. A medicina, até o início do século XX, era vista como verdadeira magia, com a utilização de técnicas paliativas, muitas vezes sem qualquer resultado prático, que prescindiam de embasamento científico. A cura, quando ocorria, era um mero fruto do acaso. Não era possível, diante de tal moldura, identificar a existência de um dano atribuível à conduta de um profissional por absoluta ausência de fundamentos técnico-científicos da atividade médica até então desenvolvida.

Em decorrência de tal situação, aos médicos era concedido um alto "status" de reconhecimento dentro da pirâmide social, ainda que o conteúdo da atividade praticada realmente se aproximasse, e muito, como visto, do curandeirismo. A atividade médica exercida era muito valorizada, enxergada como manifestação da nobreza de caráter humano. Por sua vez, a cura de uma patologia, quando raramente ocorrida, era atribuída a dons especiais, até mesmo sobrenaturais, do médico. Falar em pagamento de um médico pelos serviços prestados poderia ser interpretado como uma verdadeira ofensa.

Em que pese, no passado, não ser vista a medicina como atividade econômica e negocial, em razão da estrutura cultural até então vigente, o exercício dela e o acesso dos indivíduos aos tratamentos oferecidos era bastante restrito. Apenas os integrantes dos estratos socioeconômicos mais elevados usufruíam de tais faculdades. As relações intersubjetivas concernentes à saúde eram, pois, em pequeno número e bastante pessoais, em muitos casos até mesmo familiares. E por gozarem a atividade médica e os próprios esculápios de alta reputação dentro da sociedade, a remuneração era bastante elevada, concedida como uma honraria do doente ou da família ao médico. Dessa prática é que se 
tem a origem do termo "honorários".

Com tais especificidades, a saber: a ausência de uma atividade médica verdadeiramente científica; a elevação do médico a patamares especiais dentro do conceito social; o pequeno número de pessoas com possibilidade de exercício da medicina e de acesso a ela; e, por fim, a pessoalidade e o caráter não econômico das relações travadas, não havia possibilidade de aplicação efetiva e sistemática da responsabilidade jurídica aos médicos, já incidente em outros ramos profissionais.

A situação começou a se modificar com o progressivo avanço científico da medicina, ocorrido a partir do início para meados do século $\mathrm{XX}^{262}$, e com o crescente incremento do Estado social. Assim surgiu uma demanda por atividades médicas até então contida por uma precária rede socioeconômica que alijava do acesso a tais serviços uma enorme camada da população que não possuía condições financeiras para tanto.

Ressalta-se que as próprias guerras mundiais aceleraram tal processo de democratização do acesso à medicina, tanto pela necessidade de surgimento de novas técnicas que permitissem a manutenção do maior número de soldados possível pelo mais extenso tempo no "front", bem como pela demanda de que aqueles não diretamente envolvidos na batalha pudessem suprir a continuidade do embate. Há, nesse contexto bélico, ainda, a necessidade de cada Estado em afirmar e estender os braços de sua soberania aos demais, o que passou, claramente, pelo desenvolvimento médico-científico

Mediante tamanho progresso das ciências médicas e gradativo aumento do acesso das pessoas aos tratamentos de saúde, é inegável que as relações médico-paciente deram um salto quantitativo, o que fez nascer uma visão econômica dessa atividade, aumentando os conflitos e demandando uma regulamentação jurídica que impedisse tanto o cometimento de abusos pelo Estado, quanto pautasse as condutas dos indivíduos nas relações entre os particulares.

Em um primeiro aspecto, alicerce de toda a discussão recente sobre o direito à saúde $^{263}$, a proteção jurídica visa a proteger os voluntários participantes de pesquisas

\footnotetext{
262 "O progresso científico abre as portas à verificação das regras e a medicina se transforma de arte, quase mágica, em ciência experimental. (Il progresso scientifico apre le porte alla verificabilità delle regole e la medicina si trasforma da arte, quasi magica, a scienza sperimentale)". In PINNA, Alice. "Autodeterminazione e consenso: da regola per i trattamenti sanitari a principio generale". pp. 589-610. In: Contratto e impresa. $\mathrm{n}^{\circ}$ 3, anno 22. CEDAM. Padova, 2006. p. 589.

${ }^{263}$ Destinado tanto à normatização das atividades de saúde desenvolvidas pelos Estados, quanto às relações travadas entre os particulares.
} 
clínicas, estabelecendo, como visto, a necessidade de obtenção de consentimento informado, bem como a responsabilização dos pesquisadores e patrocinadores pelos danos eventualmente ocasionados.

Surgem novos conceitos específicos que executam a difícil tarefa de conciliação entre a prestação de uma atividade e o objeto de tal prestação, a saúde dos indivíduos, valor tão delicado e inerente à personalidade humana.

Como já tratado, aumenta-se constantemente a demanda dos indivíduos por novos produtos e tratamentos que mantenham a boa saúde e prolonguem suas vidas, o que, consequentemente, faz crescer a necessidade de realização de experimentos a fim de atestar a eficácia das novas descobertas.

Por tal situação, a medicina do século XX e do atual desenvolve novas áreas que não possuem uma finalidade diretamente terapêutica, e isso acaba por criar novas exigências de conduta aos profissionais atuantes nestas áreas. É o caso dos tratamentos médico-estéticos, de um modo geral, das técnicas destinadas tanto à reprodução humana, quanto à esterilização, anestesiologia, dentre outros.

Quanto à natureza de tais obrigações, tenta-se conciliar uma visão clássica que identifica as obrigações médicas como de meio, com aquela referente às atividades descritas que não possuem um fim terapêutico imediato, consubstanciando evidentes obrigações de resultado. Por meio dessa compatibilização, procura-se identificar e desenvolver os elementos diferenciadores que permitam tratar as questões de acordo com as especificidades de cada ramo.

Ainda quanto à responsabilização civil dos profissionais atuantes na área da saúde, é possível identificar novas teorias que partem da premissa de que nas relações jurídicas de saúde nem sempre é possível identificar uma evidente ligação entre um dano e uma conduta ilícita. Em virtude disso, tais teorias buscam estabelecer novos paradigmas que instituem pontos de vista diversos dos tradicionais quanto ao chamado nexo causal, como as denominadas teorias da perda de uma chance e a de incremento dos riscos.

Portanto, analisar o atual estágio evolutivo das obrigações de saúde, identificar o caráter negocial das relações jurídicas daí advindas, bem como estabelecer o modo de aplicação da responsabilidade civil neste ramo, é tarefa de suma importância para que se permita ao Direito evitar ou corrigir a existência de situações litigiosas tão delicadas e com ampla repercussão individual e social, uma vez que ligadas a tão caro bem, indissociável 
da personalidade humana, como é a saúde.

3.2.1.2. Da natureza das relações entre pesquisadores e pacientes.

As relações jurídicas estabelecidas entre pesquisadores/patrocinadores e pacientes sujeitos de pesquisa clínica possui evidente traço negocial, notadamente em razão da relevância assumida pelo chamado consentimento informado ${ }^{264}$. Isso porque, por meio de um acordo de vontades, as partes regulam o modo de sua atuação no decorrer do processo de experimentação, estabelecendo-se os direitos e obrigações recíprocos ${ }^{265}$.

Destaca-se ainda que a manifestação de vontade concordante, no caso do paciente, deve ser precedida de uma fase de esclarecimento informativo acerca dos objetivos, maneira de realização, contrapartidas, riscos, benefícios, possibilidade de administração de placebos, se for o caso, acompanhamentos médicos acessórios a serem realizados, a liberdade de desligamento a qualquer instante, dentre outras especificidades analisadas no caso concreto.

Por ser voltada à aferição da segurança de administração de certos medicamentos ou da realização de procedimentos na área de saúde e por não envolver remuneração direta de qualquer uma das partes envolvidas, sem natureza econômica, pois, claro se mostra que não se está diante de uma verdadeira prestação de serviços.

${ }^{264}$ De maneira geral, na presente pesquisa, não se encontrou qualquer referência ao caráter contratual estabelecido entre pesquisador/patrocinador e paciente. Nesse sentido, como referência básica e primeira, foram utilizados os posicionamentos relativos às atividades médicas em geral, a fim de afastar eventuais argumentos que considerem a saúde como objeto insuscetível de ser parte de uma relação contratual, por suas especificidades. A posição majoritária, atualmente, está no sentido de as relações entre profissionais da saúde e pacientes poderem ser tipicamente contratuais. "Apesar de o Código Civil brasileiro colocar a responsabilidade médica dentre os atos ilícitos, não mais acende controvérsias caracterizar a responsabilidade médica como ex contractu". KFOURI NETO, Miguel. Responsabilidade Civil do Médico. $7^{\mathrm{a}}$ ed. rev. atual. e ampl. São Paulo: Editora Revista dos Tribunais, 2010. p. 74. No mesmo sentido: MATIELLO, Fabrício Zamprogna. A responsabilidade civil do médico. $3^{\mathrm{a}}$ ed. São Paulo: LTr, 2006. pp. 44-46; LORENZETTI, Ricardo Luis. Responsabilidad civil de los médicos. Tomo I. Buenos Aires: Rubinzal-Culzoni Editores, 1997. p. 312 e ss.

265 "Em suma, no período aproximado de uma década, a partir da afirmação da natureza extracontratual da responsabilidade, sustentou-se, em um primeiro momento, o princípio do concurso das responsabilidades, contratual e aquiliana, até se chegar, finalmente, à sua configuração como responsabilidade estritamente contratual, em paralelo com a modificação das regras sobre o nexo de causalidade e sobre o ônus da prova. (In breve, nell'arco di qualche decennio alla affermazione della natura extracontrattuale della responsabilità se è in un primo tempo affiancato il principio del concorso di responsabilità, contrattuale e aquiliana, per arrivare infine alla sua configurazione come responsabilità schiettamente contrattuale, in parallelo con la modificazione delle regole sul nesso di causalità e sull'onere della prova)". PARADISO, Massimo. "La responsabilità medica dal torto al contratto". In: Rivista di Dirito Civile. n 3, Anno XLVII, maggio-giugno 2001. Padova: CEDAM, 2001. pp. 325-352. p. 325. 
Trata-se de contrato bilateral, já que resultam obrigações para ambas as partes: ao paciente a participação na pesquisa de acordo com as recomendações do pesquisador/patrocinador; a este manter ao máximo informado aquele, bem como seguir os parâmetros estabelecidos no protocolo de pesquisas devidamente aprovado pelos órgãos competentes e pelo sujeito, com fim único de garantir o acompanhamento da saúde do participante e a tomada de medidas necessárias e adequadas à manutenção da incolumidade deste ou de atenuação de eventuais efeitos deletérios advindos do processo.

A situação pode assumir, também, a feição de contrato gratuito ou oneroso, caso se verifique, neste último caso, algum efeito positivo ao paciente, como sói ocorrer nas pesquisas terapêuticas. Desse modo, sempre se tem em vista a produção de reais benefícios aos pesquisadores/patrocinadores, consubstanciados na conclusão sobre a viabilidade ou não de um determinado tratamento médico, afora aqueles posteriores e pecuniários, caso o teste demonstre o cabimento da comercialização do produto experimentado.

É de se notar, ademais, que tal constatação, sobre a natureza do acordo em análise, possui efetiva influência sobre a verificação da posição ocupada pelo paciente em face dos pesquisadores e empresas atuantes na área da saúde e o tipo de responsabilização civil dos envolvidos, bem como quais as consequências advindas em razão da execução das pesquisas clínicas, quando da ocorrência de um dano.

Não há dúvida, ademais, que se está diante de um contrato de adesão, com cláusulas pré-definidas pelos pesquisadores/patrocinadores, e aprovadas pelos Comitês de Ética em Pesquisa e pelo CONEP, quando o caso, o que se mostra necessário para a conservação do rigor científico do trabalho realizado. Assim, resta ao paciente apenas a possibilidade de discussão de cláusulas meramente acessórias, como o oferecimento de transporte e alimentação gratuitos.

Não se trata, ainda, de relação sujeita, diretamente, às disposições do Código de Defesa do Consumidor, pois ausente a questão da prestação de serviço ou produto, e não se amoldam as partes contratantes aos conceitos de consumidor e fornecedor carreados pelos artigos $2^{\circ}$ e $3^{\circ}$, respectivamente, da mencionada $\mathrm{Lei}^{266}$.

Destarte estabelecida a natureza contratual das relações em análise, é mister

\footnotetext{
266 Já os contratos ordinários entre médicos e pacientes são regidos pelo Código de Defesa do Consumidor, mantendo-se, todavia, a responsabilidade subjetiva do médico, de acordo com o artigo $14, \S 4^{\circ}$.
} 
que se reconheçam as obrigações principais, objetos de tais contratos, e que se avaliem, também, as consequências oriundas do cometimento de um eventual ilícito contratual.

Todavia, para que se compreenda a efetiva caracterização dos elementos condicionantes da responsabilidade civil no que tange às pesquisas clínicas, é necessário realizar algumas ponderações sobre os delineamentos gerais dessa matéria, bem como no âmbito das relações médicas ordinárias.

\subsubsection{As obrigações médicas de meio}

Inegável que as obrigações médicas, classicamente, possuem finalidade diretamente terapêutica, ou seja, destinadas à cura de patologias que acometem os indivíduos. Tal ponto de partida, ainda que em certa medida relativizado no atual contexto social e científico, como melhor tratado em tópico posterior, é ainda o principal elemento identificador das características que permeiam as relações jurídicas contratuais entre médicos e pacientes.

E diante de tal realidade, a atividade médico-terapêutica, complexo de atos interdependentes destinados à finalidade de cura do paciente, lida com inúmeros fatores imprevisíveis ligados às especificidades anatômicas e biológicas de cada indivíduo submetido aos tratamentos que, infelizmente, não permitem aos médicos assegurar, nas diversas situações, a certeza do objetivo visado.

Propala-se que a atividade médica, nesse sentido, estaria permeada por alguns riscos cujo controle não poderia ser regido por aqueles que exercem a medicina e que poderiam, além de dificultar o atendimento da finalidade terapêutica, causar danos aos pacientes. Exatamente neste cenário, em que nos tratamentos influem tanto fatores ligados diretamente à conduta dos médicos, quanto fatores externos imprevisíveis e de difícil controle, e levando ainda em consideração a classificação entre obrigações de meio e de resultado, sistematizada juridicamente por Demogue ${ }^{267}$, é que surge a afirmação de que as obrigações médicas terapêuticas são daquelas classificadas como de meio.

Observa-se que a diferenciação referida terá importante repercussão quanto à verificação da ilicitude de uma determinada conduta ocasionadora de um suposto dano, antijuridicidade estabelecida, como se verá posteriormente, como pressuposto necessário à

${ }^{267}$ LORENZETTI, Ricardo Luis. ob. cit. p. 471. 
responsabilização civil subjetiva do agente.

Nos tipos de obrigações denominadas de meio, o conteúdo destas é a própria atividade desenvolvida pelo agente, conforme leciona Teresa Ancona Lopez ${ }^{268}$ :

[e]sse tipo de obrigação é o que aparece na maioria dos contratos de prestação de serviços de médicos, advogados, publicitários etc., quando a própria atividade do devedor é o objeto do contrato. Esta atividade tem de ser desempenhada da melhor maneira possível, com a diligência necessária para o melhor resultado, mesmo que este não seja conseguido.

Nota-se que a avaliação de um determinado tratamento médico, e do consequente adimplemento do contrato celebrado, será direcionada à conduta do médico durante o desenrolar da atividade, ou seja, se houve a correta utilização dos instrumentos adequados à obtenção do resultado da cura, ainda que este não tenha sido efetivamente atingido $^{269}$.

É evidente, de outro modo, que o resultado serve como parâmetro útil para aferição da adequação e aptidão dos meios ao alcance da finalidade terapêutica cabível e proposta por determinado procedimento médico.

Entretanto, danos podem emergir do desenvolvimento negligente da própria atividade exercida, sem necessariamente estarem ligados à adequação dos meios ao objetivo cura, exatamente por serem as obrigações médico-terapêuticas obrigações de meio, com enfoque, como visto, na própria atividade desenvolvida, situação esta em que se estará diante de um inadimplemento contratual ${ }^{270}$.

268 O dano estético: responsabilidade civil. $2^{\mathrm{a}}$ ed. Ed. Revista dos Tribunais, São Paulo, 1999. p.53.

2697 "Em razão da própria falibilidade da ciência, costuma-se dizer que a obrigação do médico é de meio e não de resultado. Dito de forma diferente: o profissional da medicina jamais deve prometer a cura do doente. Seu compromisso resume-se em prestar sempre um serviço diligente e cuidadoso, de acordo com os recursos técnicos existentes dos quais se possa utilizar". GUIMARÃES, José Alfredo Cruz. "Responsabilidade médico-hospitalar em face do Direito do Consumidor". pp. 128-140. Revista de Direito Privado, $\mathrm{n}^{\circ}$ 10, ano 3, abr./jun. 2002. Ed. Revista Dos Tribunais. São Paulo, 2002. p. 131.

2707 "Assim, o resultado da cura, certamente não devido, indica e seleciona as terapias adequadas e a sua (esperada) consecução: o médico, portanto, se o doente não é curado, terá adimplido a sua obrigação desde que haja diligentemente escolhido e aplicado os cuidados necessários à obtenção da cura. Será, ao invés, inadimplente quando a terapia tiver sido inadequada ou, ainda, haver sido escolhida essencialmente para um fim diverso da cura, como a experimentação de um novo fármaco ou de um novo método terapêutico. E, analogamente, o médico resultará também inadimplente, mesmo quando o doente for curado, caso ele não haja procedido ao cuidado apropriado ou tenha cometido um erro terapêutico. (Così, Il risultato della guarigione, certo non dovuto, indica e seleziona le terapie adeguate al suo (sperato) conseguimento: Il medico perciò, pur se Il malato non guarisca, avrà adempiuto la sua obbligazione ove abbia diligentemente scelto e applicato le cure appropriate per conseguire la guarigione. Sarà invece inadempiente quando la terapia sai stata inadeguata o, magari, sai stata scelta essenzialmente per un fine diverso dalla guarigione, come sperimentare un farmaco o un nuovo metodo terapeutico. E analogamente, 
Por outro lado, a avaliação dos meios utilizados deve se pautar tanto pelo padrão médio de bom profissional em relação a cada situação e patologia específicas, quanto pelos instrumentos à disposição do médico em um determinado local e tempo. Não é exigido dos médicos o domínio de todas as técnicas existentes, não obstante devem possuir o conhecimento ao menos das técnicas mais consolidadas na literatura científica. Analisa-se também se, para obtenção da cura, seriam pertinentes as técnicas utilizadas e se a eventual desconsideração de determinado procedimento é passível de aprovação pela prática corrente e de acordo com as circunstâncias de cada caso concreto.

De maneira ilustrativa, muitas vezes há o conhecimento por parte do profissional de determinadas técnicas, mas cuja aplicação fica prejudicada em razão das limitações instrumentais presentes em determinado tempo e lugar da prestação do serviço. Nesses casos, também não haverá motivos para se cogitar a falta de diligência do profissional.

A análise do cabimento e correção dos meios utilizados pelos agentes de saúde em determinados tratamentos terapêuticos, com a consequente verificação do adimplemento contratual, é relativa, variável e baseada em um padrão de conduta médio dos profissionais atuantes nessa área. Portanto, não se exige a extrema cautela ou o irrestrito conhecimento de todas as técnicas e instrumentos postos à disposição pela ciência $^{271}$.

Il medico risulterà comunque inadempiente, pur quando il malato sia guarito, ove egli abbia omesso le cure appropriate o commesso un errore terapeutico)". PARADISO, Massimo. ob. cit. pp. 329-330.

271 O artigo 2236 do Código Civil italiano dispõe que o prestador de um serviço, no caso de um problema técnico de especial dificuldade, somente responderá em caso de culpa grave ou dolo, norma que se aplica também às relações de saúde e que criaria, supostamente, um padrão mais atenuado daquele médio, no que tange à avaliação dos meios utilizados para atendimento de determinada finalidade. Discorrendo sobre a pertinência de tal norma, Massimo Paradiso tece as seguintes considerações: "[n]ão pouca doutrina contrária critica esta reconstrução, ainda que nem sempre com argumentos convincentes. Verdade é, contudo, ao meu modo de ver, que a disposição não representa uma disposição derrogatória da regra geral do art. 1.766 do C.C. e não atribui nenhuma especial exceção ao regime ordinário de responsabilidade. Primeiramente, seria simplesmente insensato que, quando se apresentam 'problemas técnicos de especial dificuldade', seja suficiente o exercício de uma competência inferior à média. Ao contrário, a própria presença de particulares dificuldades impõe a adoção de especiais cautelas e exige a detenção de uma competência superior à média: na falta desta seria já imprudente a assunção de tal caso clínico. A norma, então, baseia-se em realidade no pressuposto de que o caso exige uma capacidade superior à média, que possuem somente alguns, bem como em termos de aparelhamento e organização necessárias para enfrentar a emergência terapêutica. E também, é em consideração a este tal superior nível de competência - que o devedor, ordinariamente, não precisa possuir com o fim de adimplir exatamente sua obrigação - que a lei sanciona somente a 'culpa grave': e isto é a falta, em tal hipotético nível superior, do patamar mínimo necessário para enfrentar estas ocorrências nestes termos, portanto, entrando-se no critério geral, já que a competência 'mínima' exigida em tal nível de prestação se constitui 
Por outro lado, como se analisará mais detidamente em tópico posterior, presentes os elementos dano, culpa do agente e nexo causal entre a conduta ilícita e o prejuízo do paciente, haverá a responsabilização contratual e subjetiva do profissional médico. Pelas características das obrigações médico-terapêuticas, a análise da conduta do profissional se direcionará à diligência deste, ao cabimento, à adequação e à regular execução dos procedimentos com objetivos de cura, independentemente do atendimento do fim proposto, ainda que isto tenha certa utilidade, como mencionado.

Caberá, em regra, ao paciente supostamente prejudicado demonstrar que o dano experimentado teve efetiva ligação com uma imperita, negligente ou imprudente ${ }^{272}$

um máximo em relação ao patamar inferior ou ordinário, bem como representa um quantum que o devedor não é ordinariamente exigido a possuir e cuja falta o exonera até mesmo da responsabilidade. (Non poca dottrina per contro, critica tale ricostruzione, se pure con argomenti non sempre convincenti. Vero è comunque, a mio modo di vedere, che la disposizione non rappresenta affatto una disposizione derogatoria della regola generale dettata dall'art. 1176 c.c. e non attribuisce alcuna speciale esenzione rispetto all'ordinario regime di responsabilità. Anzitutto sarebbe semplicemente insensato che, quando si presentino 'problemi tecnici di speciale difficoltà', sai sufficiente l'impiego di una competenza inferiore alla media. Al contrario, proprio la presenza di particolari difficoltà impone l'adozione di speciali cautele e reclama di massima, il possesso di un livello di competenza superiore alla media: in mancanza di essa sarebbe già imprudente l'assumere tale caso clinico. La norma, dunque, muove in realtà dal presupposto che il caso richieda una competenza superiore alla media, che possiedono solo alcuni, anche in termini di apparecchiature e organizzazione necessarie per affrontare l'emergenza terapeutica. Ebbene, è rispetto a tale superiore livello di competenza - che Il debitore, ordinariamente, non è tenuto ad avere al fine di adempiere esattamente la sua obbligazione - che la legge sanzione solo la "colpa grave": e cioè la mancanza, in tale ipotetico livello superiore, del livello minimo necessario per affrontare tali evenienze in tali termini, peraltro, si rientra nel criterio generale, poiché la competenza 'minima' richiesta per tale livello di prestazioni costituisce già um 'massimo' per Il livello inferiore o ordinario ed è perciò un quantum che il debitore non è ordinariamente tenuto a possedere e la cui mancanza lo esonerebbe comunque da responsabilità). ob. cit. p. 340.

272 "O médico responde por sua conduta, penalmente e civilmente, na forma culposa. Essa se manifesta quando o médico age com imperícia, imprudência, negligência e inobservância das leis ou regulamentos. A imperícia consiste na inobservância das normas técnicas típicas da atividade médica. A jurisprudência considera a imperícia como aquele 'comportamento incompatível com o mínimo de cultura e experiência exigidos da parte que seja habilitada ao exercício profissional'; em outras ocasiões, os magistrados definem a imperícia como 'a violação da diligência comum, ligada ao grau médio de cultura e capacidade profissional, ou a violação de normas técnicas geralmente aceitas em uma dada área'. A negligência representa uma atitude passiva no confronto com as obrigações e deveres, por conta de desatenção, distração ou esquecimento. É um dos modos de culpa que mais se encontra nos casos postos à apreciação do Judiciário. A imprudência consiste em um agir afobado, sem qualquer cautela que a razão ou experiência devem ditar. Segundo a jurisprudência um comportamento é imprudente quando não prevê as consequências danosas da própria ação, contrariando os preceitos da essencial prudência. (Il medico risponde del suo operato di fronte alle norme penali e civili a titolo di colpa. Essa si manifesta quando il medico agisce con imperizia, imprudenza, negligenza e inosservanza di leggi o regolamenti. L'imperizia consiste nella inosservanza delle norme tecniche tipiche dell'attività medica. La giurisprudenza considera l'imperizia con quel 'comportamento incompatibile con il minimo di cultura ed esperienza da pretendersi da parte di chi sia abilitato all'esercizio della professione'; in altra occasione i giudici hanno definito l'imperizia come 'la violazione della diligenza comune rapportata al medio grado di cultura e capacità professionale, ovvero la violazione della diligenza comune rapportata al medio grado di cultura e capacità professionale [sic], ovvero la violazione di norme tecniche generalmente accolte in una data disciplina'. 
utilização dos instrumentos necessários à obtenção da cura, a fim de que o médico seja devidamente responsabilizado ${ }^{273}$, sofrendo as consequências cíveis que advêm do cometimento de ilícitos.

Importa ressaltar novamente que o dano poderá ter conexão com o não atendimento do resultado cura, mas poderá ser, de outro modo, desvinculado deste, caso resultado de uma falta de diligência na execução de um tratamento específico.

Assim, por serem as obrigações médico-terapêuticas típicas obrigações de meio, sujeitas a inúmeros fatores imprevisíveis e não controláveis, em que se verifica a correção de determinado tratamento e adimplemento do contrato sob o enfoque da diligência do profissional quanto aos procedimentos utilizados, independentemente da obtenção ou não da cura prevista, normalmente sustenta-se que se impõe à parte que suporta um dano demonstrar a culpa do médico na utilização dos instrumentos técnicos, para que o profissional possa ser responsabilizado.

Todavia, em razão de tal entendimento possibilitar a criação de uma situação de dificuldade extrema à vítima no sentido da comprovação da culpa do profissional, na medida em que dotada de menos conhecimentos técnicos e possuir parcas informações acerca do tratamento realizado, comparativamente aos profissionais de saúde causadores do dano ${ }^{274}$, já existe na doutrina crescente tendência admitindo a possibilidade de se efetuar a redistribuição do ônus probatório ${ }^{275}$.

La negligenza è atteggiamento passivo nei confronti di obblighi e doveri a causa di disattenzione, distrazione o dimenticanza. È una delle carenze che si riscontra con maggior frequenza nell'ambito delle vicende che arrivano all'attenzione dei giudici. L'imprudenza consiste in un agire avventato, senza quelle cautele che la ragione o l'esperienza dovrebbero dettare. Secondo la giurisprudenza un comportamento è imprudente quando non prevede le conseguenza dannose della propria azione contraddicendo ai precetti di elementare prudenza)". MARIOTTI, Paolo; MASARAKI, Gianlorenzo; RIZZI, Renato. I diritti dei malati. Giuffrè Editore: Milano, 1993. p. 271.

2737 "Pelo contrário, é o cliente que, ou sua família, que tem que provar que o médico agiu com negligência, imprudência ou imperícia, para que possa receber a indenização. Isto se dá exatamente porque a obrigação que existe é de meio e não de resultado, nada tendo a ver com o contrato que existe entre o profissional e o cliente". LOPEZ, Teresa Ancona. O dano estético: responsabilidade civil.. p. 54.

274 "O encargo probatório que recai sobre o paciente - um leigo na matéria, com um acesso, muitas vezes dificultado, ao registro médico - revela-se, pois, muito pesado. Tanto mais que o recurso a peritos é oneroso e nem sempre conclusivo. A dificuldade probatória converte-se, assim, num 'escudo' protector do profissional, quase inexpugnável para o doente. Por consequência, as regras relativas ao ónus da prova deixam de ser, nestes casos, meras regras de distribuição do encargo probatório e de repartição, entre as partes, do risco a ele inerente, transformando-se em mecanismo de pré-determinação sistemática de insucesso de uma delas (o doente), em favor da outra (o médico). PEDRO, Rute Teixeira. $A$ responsabilidade civil do médico. Reflexões sobre a noção da perda de chance e a tutela do doente lesado. Coimbra: Coimbra Editora, 2008. p. 87.

275 "Por um lado a regras rígidas que atinam à posição das partes: incumbe ao autor; tem de provar os fatos 
A explicação desse posicionamento se dá por meio da genericamente denominada teoria da carga probatória dinâmica, que tem como base o alcance da verdade real e a cooperação das partes processuais no sentido da formação da livre convicção motivada do Juiz.

Se ao Magistrado é dado pacificar as relações sociais e promover, na maior medida, a Justiça, o não desempenho do encargo probatório por aquele a quem a Lei ${ }^{276} \mathrm{o}$ atribui, quando existam elementos sérios e concretos que demonstrem a confiabilidade de suas alegações, e a possibilidade real e não excessivamente dificultosa de que a parte adversa proceda à tarefa da demonstração da inexistência da situação afirmada, não poderá servir como sustentáculo de uma decisão denegatória de seu direito. Não que a disposição legal seja despida de importância, apenas se sustenta o seu abrandamento, quando uma das partes tiver melhores condições concretas de comprovar o seu direito ${ }^{277}$.

Deve-se destacar que se trata de uma distribuição operada pelo próprio Magistrado, independente da existência dos pressupostos necessários à inversão do ônus da prova carreada no artigo $6^{\circ}$, inciso VIII, do Código de Defesa do Consumidor, quais sejam hipossuficiência ou verossimilhança, podendo ocorrer em qualquer tipo de relação jurídica litigiosa, consumerista ou não.

Tal redistribuição pode ser aplicada, principalmente, no que concerne ao objeto

constitutivos. De outro, as que levam em consideração a norma material: há de demonstrar os pressupostos de fato da pretensão que invoca. Tudo revolucionado por dois aspectos: - A introdução de princípios extraprocessuais: princípios protetivos pro damato parte débil, do consumidor. - A aparição de processos complexos. É claro que neste contexto não se pode manter uma posição rígida e surge a flexibilização. (Por un lado las reglas rígidas que atienden a la posición de las partes: incumbe al actor; hay que probar los hechos afirmativos. Por otro lado las que toman en cuenta la norma sustantiva: hay que demonstrar los supuestos de hecho de la pretensión que se invoca. Todo ello revolucionado por dos aspectos: - La introducción de principios extraprocesales: principio protectorios pro damato parte débil, del consumidor. - La aparición de procesos complejos. Es claro que en este contexto no puede mantener_-se una posición rígida y surge la flexibilización_”. LORENZETTI, Ricardo Luis. ob. cit. p. 217.

276 Artigo 333, do Código de Processo Civil.

277 “Impende esclarecer que o dever do médico é de colaborar e não de provar. Se cumprida a colaboração, mas o fato não restou provado, haverá de prevalecer a solução segundo o ônus da prova. Se há recusa de colaborar, o juiz poderá decidir contra a parte que assim agiu, porém não para tê-la, automaticamente, como culpada. Teria o magistrado de aplicar as regras sobre prova indiciária. Dos indícios existentes, reforçados pela conduta negativa, poderá o julgador formar sua convicção, segundo a experiência da vida. Não se trata, portanto, de criar um ônus da prova para quem legalmente não o tenha. $\mathrm{O}$ que há são critérios de análise da prova disponível, inspirados na técnica dos indícios e presunções (prova indireta). Sem prova alguma, enfim, jamais será possível ao juiz julgar contra o litigante que não tinha legalmente o onus probandi e que se absteve de colaborar na apuração da verdade, a não ser, como é óbvio, nas exceções de responsabilidade objetiva ou de presunção legal de culpa”. OLIVEIRA, Mariana Massara Rodrigues. Responsabilidade civil dos médicos. Curitiba: Juruá, 2008. p. 176. 
desta dissertação, à verificação sobre a existência do nexo causal entre a conduta do profissional e os danos sofridos pelo paciente, pois nem sempre entre o prejuízo alegado e a conduta do pesquisador/patrocinador da pesquisa haverá um liame direto e facilmente demonstrável por aquele, o que dificulta, mantida a visão estática de distribuição do ônus da prova, sobremaneira o seu eventual direito de reparação do dano sofrido. Esse aspecto será mais bem tratado quando da análise da teoria da perda de uma chance, bem como da responsabilidade civil pelo incremento dos riscos.

\subsubsection{As obrigações médicas de resultado}

Hodiernamente, com o crescente aumento do oferecimento de novos produtos com fins não diretamente terapêuticos, a visão das obrigações médicas como aquelas de meio já não é suficiente para uma efetiva e integral tutela do direito dos pacientes submetidos à atividade em comento. Isso porque, nos casos das obrigações não terapêuticas, por exemplo, tratamentos estéticos, anestesiologia, exames laboratoriais, procedimentos para controle da natalidade e técnicas reprodutivas, o atendimento da finalidade almejada com tais procedimentos é componente inexorável à aferição do adimplemento dessas obrigações.

Nesses tipos de tratamentos e procedimentos, ainda que sujeitos a riscos e fatores imprevisíveis, o objetivo proposto a ser alcançado é a razão da própria existência e viabilidade das atividades como ramos especiais da medicina. O fator álea, em tais casos, ao contrário do que ocorre nas obrigações de meio, mostra-se, pelos instrumentos técnicos disponíveis, bastante enfraquecido.

Ora, a natureza de um exame laboratorial pressupõe o diagnóstico sobre a presença ou não de determinada patologia. A realização de uma cirurgia estética está ligada indissociavelmente ao atendimento do resultado querido pelo paciente, sendo a obtenção de tal resultado inclusive a causa da decisão deste em se submeter a tal procedimento. $\mathrm{O}$ caso de aplicação de anestesias demanda que o paciente possa sofrer determinada intervenção cirúrgica de maneira tranquila, sem dores e sem reações adversas.

Exatamente por tais características, como se constata nos casos elencados, apregoa-se que tais obrigações seriam daquelas do tipo de resultado, em que o médico promete e se obriga ao cumprimento de determinada finalidade, sendo que caso isso não 
ocorra, não haverá adimplido a sua prestação. Todavia, este inadimplemento poderá ou não gerar a responsabilidade do agente, conforme possa ser imputado culposamente a si.

Assim, há casos em que o enfoque sobre a correção de determinado tratamento muda da atividade em si, como nas obrigações de meio, para o atendimento ou não do fim almejado pelo médico e pelo paciente com a realização da atividade proposta. $\mathrm{O}$ não alcance do resultado, previsto pelo profissional, pode gerar o inadimplemento contratual, fato este que, como visto, não ocorre, de maneira direta, no tocante às obrigações de meio $^{278}$.

Contudo, distingue-se que danos causados por uma eventual atitude culposa do médico quanto à execução dos meios, mesmo nas obrigações de resultados, podem gerar a responsabilização do profissional, exatamente pelo fato de que a boa utilização dos instrumentos técnicos durante o tratamento, necessários à consecução da finalidade almejada, integra também o conteúdo do contrato celebrado ${ }^{279}$.

O profissional de saúde, em qualquer caso, assume uma obrigação de

278 "Hoje, inversamente, ao médico requer-se outra coisa, tanto que se pode dizer superada a idéia da atividade médica como obrigação somente de meios e não de resultado. Isto reflete, na realidade, que se ordinariamente o objeto da atividade médica é o cuidado diligente, do qual esta além a cura como resultado devido, são cada vez mais numerosas as hipóteses nas quais no contrato vem claramente previsto um resultado, cujo não cumprimento caracteriza o inadimplemento e, se o caso, a responsabilidade. Basta pensar nas próteses dentárias, na cirurgia estética e reconstrutiva, nos exames laboratoriais; e ainda nos tratamentos farmacológicos de fortalecimento muscular e nas intervenções cirúrgicas de esterilização, de modificação do gênero sexual. Aqui, o interesse diretamente deduzido no contrato é o alcance de um certo resultado útil, não o certo interesse a uma mera atividade diligente $\mathrm{e}$ tanto menos somente o interesses de não sofrer danos injustos. E isto é, pois, a bem ver, o significado concreto que assumem determinadas conclusões jurisprudenciais sobre o tema da distribuição do ônus da prova, sobre o qual incidirá o seguinte: de fato, não poucas prestações médicas constituem atualmente verdadeiras obrigações de resultado. (Oggi viceversa al medico si chiede ben altro, tanto che può dirsi ormai superato lo stesso riferimento all'attività medica come obbligazione soltanto di mezzi e non di risultato. Si rifletta infatti che se ordinariamente oggetto dell'attività medica è la cura diligente, da cui esula la guarigione come esito dovuto, sono sempre più numerose le ipotesi in cui nel contratto viene schiettamente dedotto un risultato, il cui mancato conseguimento comporta inadempimento e, se del caso, responsabilità. Basti pensare alle protesi dentarie, alla chirurgia estetica e ricostruttiva, alle stesse analisi cliniche; e ancora ai trattamenti farmacologici di potenziamento muscolare e agli interventi chirurgici di sterilizzazione, di modificazione dei caratteri sessuali. Qui, l'interesse direttamente dedotto in contratto è Il conseguimento di un certo risultato e di un risultato utile, non certo l'interesse a una mera attività diligente $\mathrm{e}$ tanto meno il solo interesse a non subire danni ingiusti. E questo è poi, a ben vedere, il significato concreto che assumono certe affermazioni giurisprudenziale in tema di distribuzione dell'onere della prova, sulle quali ci si soffermerà nel prosieguo: di fatto, non poche prestazioni mediche costituiscono oggi vere e proprie obbligazioni di risultato (...))". In PARADISO, Massimo. ob. cit. p. 335

279 José de Aguiar Dias, com muita propriedade, lista outros deveres que integram o conteúdo da relação travada entre profissional de saúde e paciente: "[d]ecompondo as obrigações implícitas no contrato médico, verificamos que ele impõe aos médicos estes deveres: 1) conselhos; 2) cuidados; 3) obtenção do consentimento; 4) abstenção de abuso ou desvio de poder; 5) dever de sigilo". Da responsabilidade civil. $11^{\text {a }}$ ed. rev., atual. de acordo com o Código Civil 2002, e aum. por Rui Berford Dias. Rio de Janeiro: Renovar, 2006. p. 337. 
segurança, ou proteção, em relação ao paciente, assumindo ações voltadas a não lesá-lo, com vistas a evitar o agravamento dos riscos, bem como não diminuir as chances de obtenção da cura ou preservação da saúde almejadas ${ }^{280}$. Essa realidade não ocasiona, porém, caso haja seu descumprimento, o nascimento da responsabilidade objetiva do agente, já que é necessário indagar acerca da existência de culpa do agente.

Tal característica marcante das obrigações de resultado, ou seja, de necessidade de atendimento da finalidade colocada, tem efetiva repercussão no tocante ao ônus da prova quanto ao adimplemento de uma determinada prestação assumida por um profissional médico e à consequente responsabilização.

Ao modificar-se o prisma da avaliação para o atendimento do objetivo de um tratamento ou procedimento, fica caracterizado um efetivo inadimplemento ${ }^{281}$ nos casos em que tal fim, culposamente, não tenha sido alcançado. A não consecução da finalidade acaba por criar a presunção relativa, frise-se, acerca da responsabilidade do agente.

Demonstrado que determinado resultado, quer proposto pelo médico, quer decorrência intrínseca de determinado procedimento, seja querido ou esperado pelo paciente quando submetido àquela específica atividade médica, não foi alcançado, nasce para o profissional médico a necessidade de demonstrar que o não atendimento do fim se deu por fatores imprevisíveis ou não controláveis. Caberá ao profissional romper, exatamente, a presunção de culpa e a consequente ligação causal entre a não obtenção do resultado e a conduta assumida ao longo do processo. Tal presunção é, pois, do tipo relativa, que pode ser elidida por prova em contrário, e não gera qualquer responsabilização objetiva do médico, como se verá posteriormente ${ }^{282}$.

280 "Parece-nos, então, que o médico assume uma obrigação principal (de meios) de implementar todos os mecanismos que a ciência médica disponibiliza, para aproveitar as possibilidades (rectius, chances) que o doente apresenta de alcançar a finalidade pretendida, e ao mesmo tempo, uma obrigação de protecção (de resultado) de se abster de qualquer acto (positivo ou negativo) que diminua ou elimine essas possibilidades. PEDRO, Rute Teixeira. ob. cit. p. 82.

281 Entende-se neste trabalho que a transgressão de um preceito legal ou contratual caracteriza, por si só, o ato ilícito, sendo a determinação do dano e da culpa, naqueles casos em que esta tenha de ser demonstrada, uma questão de se aferir a existência da responsabilidade civil indenizatória. Por isso, nas obrigações de meio, o inadimplemento contratual só restará configurado quando provada a transgressão de um dever objetivo de conduta por parte do profissional, já nas de resultado, estará caracterizado o ilícito negocial, quando não cumprido o objetivo proposto, sendo a avaliação da culpa influente para se afirmar a obrigação de reparar o prejuízo pelo autor do ilícito.

2827 "Não se pode negar o óbvio, que decorre das regras de experiência comum; ninguém se submete aos riscos de uma cirurgia, nem se dispõe a fazer elevados gastos, para ficar mais feio do que já era, ou com a mesma aparência. O resultado que se quer é claro e preciso, de sorte que, se não for possível alcançá-lo, caberá ao médico provar que o insucesso - total ou parcial da cirurgia - deveu-se a fatores 
Diferente das obrigações de meio, no caso das obrigações de resultado, ao médico caberá o ônus da prova (havendo efetiva inversão deste encargo em um processo judicial, afinal caberá ao réu demonstrar a inexistência de culpa e nexo causal), desde que aquele que sofreu as repercussões dos prejuízos demonstre a não obtenção do resultado proposto.

As regras e características citadas aplicar-se-ão, também, nos casos em que o paciente consiga provar que o profissional prometeu e assegurou, de maneira inequívoca, o atendimento de determinado fim, posteriormente frustrado, ainda que se trate de típica obrigação de meio.

Há, portanto, uma efetiva inversão do ônus da prova, que não pode ser entendida como uma responsabilização objetiva do profissional. O mesmo juízo aplica-se quanto às obrigações de meio, caso haja uma indubitável promessa e garantia de alcance dos resultados propostos efetuadas pelo médico.

\subsubsection{A responsabilidade civil nas práticas médicas em geral}

Independentemente das obrigações serem de meio ou de resultado, conforme delineado, fato é que a atividade médica ordinária lida com fatores imponderáveis e que muitas vezes acabam por prejudicar, sem a participação de qualquer ato culposo comissivo ou omissivo por parte do profissional médico, o alcance do sucesso de determinado tratamento, ainda que não terapêutico.

Como visto, a diferenciação entre obrigações de meio e de resultado é útil conforme permita estabelecer a distribuição do ônus da prova, bem como qual enfoque tais provas deverão assumir em um eventual processo civil de responsabilização do profissional. Em ambas as situações, em geral, a responsabilidade do médico, caso ocorra um dano, estará afastada se os prejuízos experimentados ou o resultado não atingido estejam ligados causalmente a fatores não passíveis de previsão ou controle pelo

imponderáveis. E como se justifica essa obrigação de resultados do médico em face da responsabilidade subjetiva estabelecida no CDC para os profissionais liberais? A indagação só cria embaraços para aqueles que entendem que a obrigação de resultados gera responsabilidade objetiva; sempre sustentei, todavia, que a obrigação de resultado apenas inverte o ônus da prova; a responsabilidade continua sendo subjetiva, mas com culpa presumida". CAVALIERI FILHO, Sérgio. "A responsabilidade médico-hospitalar à luz do Código do Consumidor”. In: Revista Forense. v. 346, ano 95. Rio de Janeiro, abr./mai./jun. 1999. pp. 131141.p. 141. 
profissional.

E exatamente pela possibilidade da existência desses elementos imponderáveis, tradicionalmente está bem sedimentado que a responsabilização dos médicos depende da presença de conduta culposa ocasionadora do dano experimentado pela vítima, ainda que a culpa seja relativamente presumida, como nos casos das obrigações de resultado.

Ainda que se esteja, em geral, diante de uma relação contratual entre o agente de saúde e o paciente, é preciso ressalvar que essa álea presente nas atividades médicas e a insuficiência de avaliação do cumprimento ou não do resultado para se verificar o inadimplemento, sendo necessária também a análise da culpa na própria conduta do profissional, tendem a afastar a responsabilidade civil nessa seara do esquema contratual ordinário $^{283}$, previsto pelos artigos 389 e ss. do Código Civil.

$\mathrm{Na}$ realidade, a responsabilidade dos médicos, apesar de baseada em um contrato, frisa-se novamente, aproxima-se de um padrão aquiliano ${ }^{284}$, seguindo o esquema clássico subjetivo $^{285}$. Ela nasce a partir da existência dos elementos conduta antijurídica e culposa do agente, dano e nexo causal entre a ação antijurídica e o prejuízo à vítima, noção geral esta albergada pelo artigo 186 do Código Civil ${ }^{286}$.

283 “Então não só o comportamento lesivo de um médico funda, em princípio simultaneamente uma responsabilidade de natureza contratual e extracontratual, como existe uma unidade da ilicitude na actividade médica. Esta proximidade manifesta-se no facto de a aceitação do paradigma contratual não ter importado qualquer alteração na avaliação do desvalor da conduta médica, na medida em que se incorporou no vínculo contratual o padrão de comportamento exigível no âmbito aquiliano e que resulta, em larga medida, do conteúdo do juízo de culpa. Verificou-se uma subjectivação do tipo de ilícito contratual”. PEDRO. Rute Teixeira. ob. cit. p. 114.

284 "Independente de ser contratual ou extracontratual, o problema para quem deseja responsabilizar um profissional médico é a prova de sua culpa, pois ela é pressuposto da responsabilidade subjetiva". ROMANELLO NETO, Jerônimo. Responsabilidade civil dos médicos. $2^{\mathrm{a}}$ ed. São Paulo: Biblioteca $24 \mathrm{X}$ 7, 2009. p. 57.

285 "Sendo subjetiva a responsabilidade pessoal do médico, como na realidade o é, não bastará o mero insucesso do tratamento, seja clínico ou cirúrgico, para ensejar o seu dever de indenizar. Caberá à vítima provar não só o dano e o nexo causal como na responsabilidade objetiva, mas também a culpa do médico. CAVALIERI FILHO, Sérgio. ob. cit. p.138. Aliás, conforme nota anterior, o autor expressamente afasta a possibilidade de responsabilização objetiva dos médicos, deixando bem clara a diferenciação entre este conceito e aquele de obrigação de resultado.

286 "Há constante confusão entre pressupostos e fundamentos da responsabilidade civil, o que conduz a grave falhas na verificação da existência ou não do dever de reparar os danos daquele que age e causa prejuízo a alguém. A identificação exata do significado de pressupostos e de fundamentos leva à organização das idéias e à clareza do raciocínio lógico na apreciação do caso concreto. Note-se que não se trata de firula terminológica a distinção entre pressupostos e fundamentos, mas de utilização de instrumental técnicojurídico indispensável na responsabilidade civil. Os pressupostos são ação [ou omissão], o dano e o nexo causal entre a ação e o dano. Os fundamentos podem ser a culpa (dolo, negligência, imperícia e imprudência) ou o risco (previsto em lei ou decorrente da atividade normalmente exercida pelo agente). SILVA, Regina Beatriz da. "Pressupostos da responsabilidade civil na área da saúde". In: SILVA, Regina Beatriz Tavares da. Responsabilidade civil na área da saúde. São Paulo: Saraiva, 2007. p. 09. 
O inadimplemento contratual imputável ao agente é verificado não apenas quando se constata o insucesso no alcance do resultado almejado, o que torna necessário avaliar a situação de acordo com a álea atuante em determinado procedimento médico. A perquirição, no caso, é objetiva, no sentido de que se concentra na constatação da existência ou não de instrumentos adequados que, se utilizados da maneira correta e previsível, poderiam evitar o dano causado ou mesmo possibilitar a realização do objetivo desejado.

Faz-se mister ressaltar que a análise sobre a existência do não cumprimento das obrigações inerentes ao contrato de prestação de serviços médicos já pressupõe, de maneira concomitante, a verificação da existência do dano e do nexo causal.

Verificado o inadimplemento, deve ser estimado o desvalor subjetivo da conduta do profissional, ou seja, se sua ação ou omissão foi culposa. Nesse momento, não se analisa mais a existência de meios adequados ao alcance do resultado, somente se levam em conta as características pessoais do profissional de saúde e as específicas do caso ${ }^{287}$ posto sob sua atuação e em que proporção poderia ser exigida um modo de proceder diferente $^{288}$, apto a evitar os danos causados.

Muitas vezes, por exemplo, em que pese a existência da técnica apropriada, esta não está acessível ao profissional, ou mesmo duas possibilidades cientificamente e igualmente adequadas ao caso concreto abrem-se ao mesmo agente, sendo necessária a

287 "Pouco ou quase nada adianta falar que o médico deve proporcionar ao paciente o melhor da técnica e dos conhecimentos disponibilizados pelo estado da arte médica na ocasião, se ao médico faltam os equipamentos, o pessoal, a estrutura física, as verbas para manutenção dos equipamentos. Nessa caótica situação real, o ideal perde espaço e os deveres do médico devem ser, assim, apreciados segundo o que qualquer outro médico, em sua situação, seria capaz de fazer”. DIAS, José Aguiar. ob. cit. p. 333.

288 "Quando um paciente inesperadamente morre ou sofre danos no curso de um procedimento médico, uma reação comum é atribuir a responsabilidade pela morte ao médico envolvido. Isto não somente pode ser feito pela família, mas pelo próprio hospital que pretende colocar toda a culpa no médico. Pode haver ocasiões em que isto se mostre cabível e o problema claramente é do médico. Frequentemente, todavia, a situação é muito mais complicada. As inadequações do sistema, as específicas circunstâncias do caso, a natureza da psicologia humana e o puro acaso podem se combinar no sentido da produção do resultado, em que a contribuição do médico é relativa ou mesmo sem qualquer culpa. (When a patient unexpectedly dies or is harmed in the course of a medical procedure, a common reaction is to attribute responsibility for the death to the medical practitioner involved. Not only may this be done by the family, but often the hospital itself will tend to lay the blame on the individual doctor. There may be occasions when this will be entirely appropriate, and where the problem clearly does lie with the doctor. Very often, however, the situation is much more complicate. The inadequacies of the system, the specific circumstances of the case, the nature of human psychology itself, and sheer chance may have combined to produce a result in which the doctor's contribution is either relatively or completely blameless)". MERRY, Alan; SMITH, Alexandre McCall. ob. cit. p. 10. 
escolha de uma apenas ${ }^{289}$, razão pela qual não se pode vislumbrar, propriamente, culpa no seu agir, o que impede, portanto, o nascimento da responsabilidade pelos prejuízos advindos.

Entretanto, uma parcela da doutrina entende que quando a obrigação médica for do tipo de resultado, o não atendimento do fim almejado ensejará a responsabilização independentemente de que seja verificada a culpa do profissional ${ }^{290}$, em um verdadeiro esquema objetivo.

Aliás, tal ideia equivocada vem intimamente ligada a uma patente confusão entre os conceitos de obrigação de resultado (e da consequente presunção relativa de culpa advinda deste parâmetro), e a própria responsabilização objetiva ${ }^{291}$. Todavia, como analisado, tais institutos jurídicos possuem conteúdo bastante diverso e com destinações totalmente diferentes.

Obrigações de resultado seriam aquelas em que o não atendimento de uma finalidade proposta, sendo este a consubstanciação do dano, enseja a presunção relativa de culpa do agente e do nexo causal entre a conduta e o dano. A presunção por ser relativa possibilita que o agente médico a elida, mediante a comprovação da existência de fatores imponderáveis, que não necessariamente de força maior, caso fortuito ou culpa exclusiva

289 "[S]e existe uma liberdade do paciente, há também uma liberdade do médico que não pode ser sacrificada pelos interesses de quem quer que seja. O médico não pode, e nem deve, na realidade, aceitar a efetuação de prestações que não correspondam a uma real patologia física ou psíquica, compreendida no sentido bem amplo do reflexo existencial. Além deste limite não pode ir, e o médico não pode renunciar a sua própria capacidade diagnóstica, a sua liberdade. De outro modo, profissão (analisando a raiz da palavra) significa professar com dignidade e liberdade uma arte, bem como uma ideologia. ([S]e c'è una libertà nel paziente c'è anche una libertà del medico che non può essere sacrificata ad interessi di chicchessia. Il medico non può infatti nè deve accedere a prestazioni che non corrispondano ad una reale patologia fisica o psichica sia pure intesa nel senso più ampio proprio del riflesso esistenziale. Oltre questo limite non si può andare, e il medico non può rinunciare alla propria capacità diagnostica, alla propria libertà. D'altra parte professione (andando alle radici delle parole) significa professare in dignità e libertà un'arte vera $\mathrm{e}$ propria, oltre che un'ideologia). BARNI, Mauro. "Responsabilità del medico". In: Il rischio in medicina oggi e la responsabilità professionale. Atti del Convegno di Studio della Federazione Nazionale degli ordini dei Medici Chirurghi e degli Odontoiatri. Milano: Giuffrè Editore, 1999. pp. 115-126. p 124.

290 "A atividade do médico apresenta-se, na maioria dos casos, como obrigações de meios, porém em boa parte também assume esse profissional obrigação de resultado (a exemplo da cirurgia plástica, radiologia, anátomo-patologia) devendo, nesses casos, apurar-se objetivamente a responsabilidade, afastando-se os pressupostos da avaliação da culpa e fixando-se a relação causal entre o fato e o dano. VASCONCELOS, Fernando A. de. ob. cit. p. 47.

2917 "Responsabilidade objetiva decorre da necessidade que se tem de cobrar de quem provocou um dano a competente indenização, sem necessidade de se provar tenha agido com culpa ou dolo. Ou a culpa é presumida pela Lei ou simplesmente se dispensa sua comprovação. No primeiro caso, inverte-se o ônus da prova". Idem. p. 40. Todavia, entende-se neste trabalho que a responsabilidade objetiva não comporta qualquer argumentação de ausência de culpa pelo agente, nascendo independentemente da existência ou não desta, não havendo que se falar, pois, em inversão do ônus da prova. 
de terceiro, aptos a descaracterizar a culpa do agente, rompendo o nexo causal.

Já a responsabilidade objetiva prescinde de qualquer modo da verificação de culpa, não sendo possível afastar a sua incidência, salvo, conforme previsão legal, nos casos de força maior, caso fortuito ou culpa exclusiva de terceiro.

O primeiro conceito é útil para estabelecer o que se deve provar e quem deve proceder a esta prova apta a afastar a culpa e o nexo causal e, consequentemente, a responsabilidade, no caso do agente médico. Por outro lado, o segundo conceito não comporta tal tarefa, sendo a análise da culpa irrelevante para ensejar o nascimento da obrigação de reparar o dano causado.

3.2.1.6. Responsabilidade civil de pesquisadores e patrocinadores por danos ocorridos em sede de pesquisas clínicas com crianças e adolescentes

No âmbito das pesquisas clínicas, há uma variação importante em relação ao que foi tratado nos tópicos anteriores. Essa diversidade consiste no fato de que o pesquisador/patrocinador, ao arregimentar voluntários, esclarecê-los sobre o processo de experimentação e obter-lhes o consentimento, não promete qualquer resultado útil concreto ao paciente, mesmo porque a aferição da possibilidade real de produção deste é um dos objetos principais da pesquisa.

Além disso, eventuais resultados negativos são tidos, desde a celebração do contrato, como aceitáveis de maneira mais marcante do que aqueles previstos nas obrigações de meio ou de resultado ordinárias.

Isso ocorre em razão de que a experimentação tem como fundamento e objetivo precisos verificar, a partir da análise dos resultados obtidos com a realização de certos tratamentos, a eficácia e segurança destes, para que se possa decidir sobre a adequação da aplicação dos mesmos em larga escala ou de maneira comercial. Ainda que subsista uma preocupação terapêutica, o que pode não ocorrer em muitos casos, esta é associada àquela outra preocupação experimental deveras incerta.

De qualquer forma, mesmo que o teste esteja cercado de riscos mais elevados e de benefícios menos palpáveis, obrigam-se os pesquisadores/patrocinadores a conservar a incolumidade física e psíquica dos pacientes, a fim de minorar, de algum modo, os riscos previstos. Esse dever está expressamente previsto na Resolução 196/96 do Conselho 
Nacional de Saúde ${ }^{292}$.

Todavia, ao realizar a pesquisa clínica, pesquisadores/patrocinadores assumem como consequência bastante possível e inerente ao processo a ocorrência de danos. Se visam a aferir certos resultados, que lhes podem trazer benefícios futuros, como por exemplo econômicos decorrentes da comercialização de um fármaco, imprescindível que sejam responsabilizados, portanto, pelos riscos advindos da atividade perigosa ${ }^{293}$ que praticam.

Olhando sob o prisma dos pacientes sujeito de pesquisa, a mesma conclusão se impõe. O encargo advindo dos eventuais riscos não pode ser assumido pelos pacientes, na medida em que o objetivo principal não é a cura ou atenuação de certa patologia, como visto. Se os sujeitos de pesquisa, apenas de maneira mais remota, serão agraciados com um benefício, em termos de proteção da boa-fé e da justiça, conforme a formulação clássica ou nos quadrantes bioéticos delineados, os eventuais prejuízos a que não tenham dado causa não podem ser por eles suportados.

O que se constata, desse modo, é que a formulação tradicional acerca da responsabilidade subjetiva dos agentes de saúde não irá prevalecer quanto às experimentações clínicas.

Como dito, nesse caso das pesquisas, o resultado almejado é obter uma resposta positiva quanto à segurança e eficácia de um procedimento, ainda que o risco seja inerente.

Não há como se falar em obrigação de meio, evidentemente, pois não cabe somente ao pesquisador/patrocinador utilizar todos os instrumentos adequados para a manutenção da saúde do indivíduo.

Pode-se falar em obrigação de resultado, caso considerado como finalidade a ser garantida a prestação de assistência integral ao sujeito de pesquisa, preservando-lhe a incolumidade física. Em tal situação, a não consecução do resultado, agora sim, terá como

${ }^{292}$ V.5 - O pesquisador, o patrocinador e a instituição devem assumir a responsabilidade de dar assistência integral às complicações e danos decorrentes dos riscos previstos.

${ }^{293}$ Não se adota de maneira irrestrita, neste trabalho, a concepção de risco proveito, até porque esta sofre críticas pertinentes. Apenas se busca demonstrar um dos aspectos que justificam a diversidade de tratamento no tocante à responsabilidade pelos riscos envolvidos no caso de experimentações clínicas, em comparação ao que ocorre nas obrigações médicas em geral. Todavia, por si só, este fator não é suficiente, de maneira isolada, para tanto, devendo ser acompanhado de outros elementos que serão demonstrados. Cf. ALONSO, Paulo Sérgio Gomes. Pressupostos da responsabilidade objetiva. São Paulo: Saraiva, 2000. pp. 63-66. 
consequência a responsabilização civil objetiva, com base no artigo 927, do Código Civil e da Resolução 196/96 do Conselho Nacional de Saúde, diferentemente daquilo que ocorre com os serviços médicos em geral.

A resolução 196/96, do Conselho Nacional de Saúde, é taxativa ao determinar a responsabilidade do patrocinador, do pesquisador, da instituição de pesquisa, e promotores do experimento ${ }^{294}$ pelos danos associados aos experimentos realizados, quer diretos ou indiretos, não se permitindo qualquer tipo de renúncia prévia ao seu direito, por parte dos sujeitos de pesquisa, nos seguintes termos:

V.6 - Os sujeitos da pesquisa que vierem a sofrer qualquer tipo de dano previsto ou não no termo de consentimento e resultante de sua participação, além do direito à assistência integral, têm direito à indenização.

V.7 - Jamais poderá ser exigido do sujeito da pesquisa, sob qualquer argumento, renúncia ao direito à indenização por dano. $\mathrm{O}$ formulário do consentimento livre e esclarecido não deve conter nenhuma ressalva que afaste essa responsabilidade ou que implique ao sujeito da pesquisa abrir mão de seus direitos legais, incluindo o direito de procurar obter indenização por danos eventuais.

Não há dúvidas de que, pela análise desse dispositivo, a responsabilidade civil daqueles agentes é do tipo objetiva, tendo em vista que inexiste qualquer referência à necessidade de comprovação de culpa para o nascimento do dever de indenizar os prejuízos tratados.

Apesar da eloquência do comando acima tratado, ele vem previsto em instrumento infralegal. A análise desse não pode ser efetuada de maneira isolada, até mesmo porque o Código Civil, que lhe é superior hierarquicamente, prevê, como regra, a responsabilidade subjetiva ${ }^{295}$. Assim, deve-se perquirir sobre a existência, no mesmo Código Civil, ou em instrumentos normativos que formalmente o equivalham ou superem-

\footnotetext{
294 Resolução 196/96:

II.4 - Pesquisador responsável - pessoa responsável pela coordenação e realização da pesquisa e pela integridade e bem-estar dos sujeitos da pesquisa.

II.5 - Instituição de pesquisa - organização, pública ou privada, legitimamente constituída e habilitada na qual são realizadas investigações científicas.

II.6 - Promotor - indivíduo ou instituição, responsável pela promoção da pesquisa.

II.7 - Patrocinador - pessoa física ou jurídica que apoia financeiramente a pesquisa.

Para evitar repetições desnecessárias, quando no presente trabalho se falar em pesquisador/patrocinador, dentro de tal conceito estarão enquadrados também os agentes acima referidos.

${ }^{295}$ GONÇALVES, Carlos Roberto. Responsabilidade civil. 11 a ed. rev. São Paulo: Saraiva, 2009. p. 24.
} 
no, de fundamento que conceda sustentação ao dispositivo em questão e que propicie a sua aplicação irrestrita.

O artigo 927, parágrafo único, do Código Civil, preceitua haver obrigação de reparar o dano, independentemente de culpa, nos casos previstos em lei, ou quando a atividade normalmente desenvolvida pelo agente do prejuízo acarretar, por característica inerente, riscos para o direito de terceiros. Nota-se que a primeira hipótese, reforçando o que foi dito em parágrafo anterior, não tem valia para a análise em questão, afinal a Resolução 196/96 não possui a qualidade de lei.

Quanto ao segundo aspecto, considerando atividade como a realização habitual de um conjunto de atos interrelacionados e organizados com vistas ao atendimento de um certo objetivo $^{296}$, de maneira segura pode-se afirmar que o dispositivo em comento confere uma sólida sustentação à responsabilidade objetiva dos pesquisadores, patrocinadores e instituição de pesquisa envolvidos.

Segundo a análise apresentada, as atividades habitualmente desenvolvidas pelos agentes acima citados portam em seu lineamento a potencialidade aguda de periclitação dos direitos dos sujeitos de pesquisa. Não se trata de riscos ordinários, que possam ser produzidos por qualquer atividade, mas anormais em relação ao que se verifica no cotidiano ${ }^{297}$.

Os riscos, nas experimentações clínicas, ainda que devam ser tomadas medidas para evitá-los ou minorá-los, são aceitos como efeito colateral deletério possível para a consecução das finalidades almejadas. Ora, quando se fala em aferir a segurança e eficácia de um determinado tratamento, subjacente a essa tarefa está, de modo evidente e quase inexorável, a presença de riscos especiais.

Fato é que os sujeitos de pesquisa estão expostos, continuamente, a potenciais danos ocasionados pelos tratamentos experimentados no âmbito dos testes, e pesquisadores, patrocinadores e instituições aceitam essa possibilidade de modo não relutante.

Destarte, a Resolução 196/96 deve ser entendida, no ponto da responsabilidade

\footnotetext{
${ }^{296}$ GODOY, Claudio Luiz Bueno de. Responsabilidade civil pelo risco da atividade: uma cláusula geral no Código Civil de 2002. São Paulo: Saraiva, 2009. p. 59.

297 "Certo então que, tanto quanto o perigo, quando a ele se vincule a norma, o risco induzido pela atividade do agente, mesmo que não essencialmente perigosa, e menos ainda defeituosa, precisa ser diferenciado, especial, particular, destacado, afinal, se toda e qualquer prática organizada de atos em maior ou menor escala o produz". Idem. p. 97.
} 
civil, como uma regulamentação específica do artigo 927, parágrafo único do Código Civil, podendo as suas disposições ser aplicadas integralmente quanto aos eventuais prejuízos causados em pesquisas clínicas, razão pela qual pesquisadores, patrocinadores e instituições serão responsáveis objetivamente por danos, quer sejam diretos, quer indiretos, devendo indenizá-los de maneira integral, o que abrange os danos patrimoniais e morais ${ }^{298}$.

Apesar da compatibilização, a melhor alternativa, como exaustivamente mencionado, seria a regulação específica das pesquisas clínicas, sobretudo as realizadas com crianças e adolescentes, por meio de lei formal, sem a necessidade de referência a outro instrumento legal construído sob parâmetros diversos daqueles necessários à melhor normatização dos experimentos científicos.

Como amplamente frisado, crianças e adolescentes possuem uma qualidade especial de pessoa em desenvolvimento, sendo mais suscetíveis, portanto, aos eventuais danos causados a sua integridade física e psíquica, pelas atividades desenvolvidas no contexto de uma experimentação clínica da qual fizessem parte. Em virtude de tal questão, o ressarcimento ou compensação dos prejuízos sofridos, no que tange de modo especial ao aspecto moral, deve levar em conta a preocupação em procurar restabelecer, da melhor maneira possível, a normalidade do processo de desenvolvimento do menor.

Ainda que, de maneira geral, a reparação específica seja recomendável ${ }^{299}$, quanto a adultos dotados de plena capacidade, conforme se constata da análise da jurisprudência, admite-se a compensação dos prejuízos à personalidade, denominados morais, mediante uma retribuição em pecúnia, que possibilite à vítima buscar a melhor forma de atenuar os efeitos deletérios produzidos.

Assim, no que concerne às crianças e aos adolescentes, pelos fatores aduzidos e também porque dotados de menor autonomia que impede a livre busca por si próprios dos meios mais adequados à reparação dos danos, o aspecto financeiro da indenização deve ceder lugar à máxima tentativa de reparação "in natura".

De acordo com esse fato, o Juiz deve buscar estabelecer ao infrator a tomada de medidas que visem à plena recomposição, no menor tempo possível, dos direitos

\footnotetext{
${ }^{298}$ Também os estéticos, caso se admita representarem estes uma categoria especial de danos, aderindo-se ao entendimento do enunciado da súmula 381 do Superior Tribunal de Justiça. Não se acolhe, neste trabalho, tal posicionamento, já que os chamados danos estéticos acarretam repercussões materiais ou morais, consubstanciadas no sentimento de vergonha própria ou repulsa pelos demais membros da sociedade.

${ }^{299}$ GARCIA, Enéas Costa. ob. cit. p. 301.
} 
violados, por exemplo, determinando o pagamento de tratamentos médicos e psicológicos, com profissionais de reputação reconhecida, a fim de evitar o prolongamento da lesão.

Importante salientar, no ponto em questão, que o chamado dano moral, ou aos direitos da personalidade, não depende, para sua caracterização, da comprovação de que o prejudicado tenha efetivamente sofrido dor, vexame ou angústia. O ferimento de um direito existencial inerente à pessoa, desde que represente uma quebra séria das expectativas nas relações cotidianas, cuidado este que evita a criação de uma sociedade de pessoas hipersensíveis, demanda a necessidade de sua reparação.

Evidente que a reparação "in natura", como proposto, exige que tenha havido um efetivo prejuízo psicológico, fato tal que, entretanto, se inexistente, pode, de acordo com o caso concreto, impor a obrigação de indenização em dinheiro. O dano, no caso, traduz-se pela não observância do respeito aos direitos da personalidade. Para ilustrar tome-se como exemplo, em outro campo jurídico, um eventual sequestro. Parece óbvio, ainda que não haja um dano psicológico à vítima, que a mera privação de liberdade represente um prejuízo o qual deva ser indenizado.

No caso das pesquisas clínicas, a não obtenção do consentimento informado, especialmente quanto a crianças e adolescentes, pode gerar a responsabilidade dos pesquisadores/patrocinadores e até mesmo dos pais, guardadas as devidas diferenças colacionadas no presente trabalho, mesmo que tenha havido um benefício ao menor e que esteja caracterizada uma real transgressão a sua autonomia.. Situações de urgência, por exemplo, ainda que experimentais ou em que a opinião do menor não deva prevalecer, podem afastar esta responsabilidade.

Observa-se que a Resolução 196/96 fala em assistência integral, a qual se relaciona ao grau de reparação ou compensação dos prejuízos sofridos e que precisa ser total. Não trata propriamente da responsabilidade objetiva integral, aquela em que não se admitem causas excludentes, de qualquer forma excepcionalíssima, e que depende de expressa disposição legal derrogadora do esquema geral do Código Civil, trazido pelo seu artigo 393, "caput” e parágrafo único.

O dispositivo legal citado determina que o devedor não responde pelo caso fortuito ou força maior ${ }^{300}$, sendo entendidos como os fatos cujos efeitos não eram possíveis

${ }^{300}$ Não se realizará a distinção entre estes dois conceitos, até porque na doutrina não há acordo sobre o 
evitar ou impedir, e que interrompem o liame causal entra a ação do agente e o dano sofrido pela vítima. Incluídos neste conceito estão o fato de terceiro ${ }^{301}$ e o fato da vítima, que não deixam de romper o nexo causal.

Ressalta-se que o artigo em comento está previsto na parte do Código que cuida da Teoria Geral das Obrigações, e independente do entendimento de se tratar de regra de aplicação geral de responsabilidade, é aplicável ao ramo ora estudado que, como visto, apesar de se aproximar da responsabilidade aquiliana, não deixa de se referir a um contrato entre pesquisador/patrocinador e sujeito de pesquisa.

Evidente que a análise dessas excludentes de responsabilidade deve ser efetuada de modo deveras cauteloso no caso das pesquisas clínicas, até porque a imprevisibilidade é inerente ao processo em questão. Não basta ao agente alegar que eventual dano foi produzido por um fato imprevisível e inevitável, porque quase todos os prejuízos causados ao sujeito de pesquisa serão ocasionados por tais tipos de acontecimentos. Deverá, em realidade, demonstrar que os danos produzidos não possuem qualquer relação com o tratamento estudado, ou seja, não estão dentro da esfera de risco assumido pelo pesquisador/patrocinador, à semelhança do que ocorre com aquela distinção bem desenvolvida no âmbito do direito do consumidor entre fortuito interno e externo ${ }^{302}$. $\mathrm{O}$ grau de risco assumido em uma pesquisa clínica é muito maior que aquele que o é nas atividades empresariais ordinárias.

De igual modo, o consentimento da vítima não poderá ser alegado, no caso em tela, como excludente, tendo em vista que, como visto anteriormente a exposição do sujeito

acontecimentos rompem o nexo causal entre a conduta do agente e o dano.

301 "Entretanto não é o simples fato de o dano ser provocado por terceiro que elimina a responsabilidade de reparação do indigitado agente. Caracteriza-se o fato de terceiro como excludente, em síntese, apenas quando; (i) a causa exclusive dos efeitos do fato prejudicial seja o fato de terceiro, porque somente então estará eliminado o vínculo de causalidade entre o dano e a conduta do autor; e (ii) o terceiro seja pessoa distinta do autor indigitado do dano e da vítima, bem como não seja, direta ou indiretamente, legal ou contratualmente, subordinado àquele. Ainda, o fato danoso deve ser atribuído ao terceiro independentemente de ser esse imputável ou ter procedido voluntariamente;”. PAULA, Carolina Bellini Arantes de. As excludentes de responsabilidade civil objetiva. São Paulo: Atlas, 2007. pp. 109-110.

302 "Entende-se por fortuito interno o fato imprevisível,e, por isso, inevitável, ocorrido no momento da fabricação do produto. Não exclui a responsabilidade do fornecedor, porque faz parte de sua atividade, liga-se aos riscos do empreendimento, submetendo-se à noção geral de defeito de concepção do produto ou de formulação do serviço. (...). O mesmo já não ocorre com o fortuito externo, assim entendido aquele fato que não guarda relação de causalidade com a atividade do fornecedor, absolutamente estranho ao produto ou serviço, via de regra ocorrido em momento posterior ao da sua fabricação ou formulação. Em caso tal nem se pode falar em defeito do produto, o que, a rigor, já estaria abrangido pela primeira excludente examinada - inexistência do defeito. CAVALIERI FILHO. Sérgio. Programa de responsabilidade civil. $9^{a}$ ed., São Paulo: Atlas, 2010. p. 185. 
de pesquisa ao risco é componente inexorável desse tipo de atividade. Entendimento diverso acabaria por redundar em uma total irresponsabilidade dos pesquisadores/patrocinadores.

Dessa forma, é inegável a responsabilidade objetiva da instituição e dos pesquisadores/patrocinadores envolvidos nas pesquisas clínicas, com base no artigo 927, parágrafo único, do Código Civil, cuja regulamentação é efetuada pela amplamente citada Resolução 196/96, responsabilidade esta não integral, admitindo excludentes, que, não obstante, para a sua configuração, dependam de uma análise bastante restritiva.

\subsubsection{A responsabilidade civil dos pais e tutores}

3.2.2.1. Obrigação de indenizar os filhos ou tutelados por danos ocorridos em pesquisas clínicas

Como analisado nos tópicos anteriores, as pesquisas clínicas são inegavelmente atividades de risco, em que a responsabilidade civil dos seus desenvolvedores é do tipo objetiva, e integral, com indenização prioritariamente efetuada "in natura".

Por outro lado, também foi afirmada a necessidade dos pais, ordinariamente, ou outros responsáveis legais, concederem a devida autorização para a participação dos menores nesses estudos, sem prejuízo em também estes serem ouvidos e terem sua opinião considerada no processo decisório. Caso seja caracterizada uma situação de perigo aos interesses das crianças e dos adolescentes envolvidos, pode-se cogitar a suspensão ou perda do poder familiar, ou destituição da tutela, conforme se abordará. Todavia, nem sempre esse tipo de sanção será suficiente à proteção dos interesses dos menores envolvidos.

Os pais ou responsáveis pelo menor ao permitirem-lhes a participação em experimentos clínicos, necessariamente terapêuticos na ordem jurídica brasileira atual, como estudado, devem fazê-lo sempre com o objetivo de preservação do melhor interesse, sendo imperioso que o teste clínico, além de propiciar um benefício em potencial que suplante os riscos possíveis, não seja um foco de produção de graves lesões aos direitos da personalidade da criança ou adolescente envolvidos. O princípio da precaução deve pautar, sem sombra de dúvidas, a tomada dessa decisão pelos pais e o posterior acompanhamento 
do desenrolar do procedimento científico.

Em qualquer sistema de controle ético do estudo, quer o atual, quer o proposto no presente trabalho, com a participação do Ministério Público, existe a possibilidade de que o ensaio acarrete danos aos sujeitos de pesquisa, ainda que tal chance seja diminuída. A aprovação pelo Comitê de Ética não exclui a responsabilidade dos pais, ou responsáveis, por eventuais prejuízos ${ }^{303}$, uma vez que a eles seja necessário salvaguardar, de maneira prioritária, os direitos infanto-juvenis. O erro do Comitê de Ética não apaga uma conduta reprovável dos pais e responsáveis.

Entretanto, os pais e responsáveis não são diretamente desenvolvedores das atividades de pesquisa, ou seja, não são os imediatos produtores dos focos de risco, tampouco possuem a possibilidade de auferirem, se seguidas as normas vigentes, qualquer ganho com a realização dos estudos, afora aqueles eventuais terapêuticos em relação aos menores sob seus cuidados.

Também não cabe afirmar que a relação entre pais e filhos, nesse caso, possui cunho negocial, na medida em que não há um acordo de vontades destinado à produção de efeitos queridos em comum. Isso decorre porque os deveres dos primeiros estão expressamente condicionados pela lei, sob o denominado poder familiar, e não são passíveis de qualquer modulação pelo exercício da autonomia privada.

Assim, a responsabilidade dos agentes, pais e responsáveis legais será do tipo subjetiva, aquiliana, calcada nos artigos $186^{304}$ e 927, “caput”, do Código Civil, sendo

303 "A responsabilidade civil é instituto aplicável ao direito de família, especialmente à relação de parentalidade, que envolve sujeitos vulneráveis, em fase de desenvolvimento, razão pela qual os pais são responsáveis pela efetivação de todas as condições necessárias à formação e realização existencial dos filhos. Embora essa possibilidade ainda seja admitida com certa restrição, principalmente na jurisprudência, a reparação dos danos patrimoniais e morais decorrentes da violação de deveres familiares é plenamente cabível, desde que presentes os elementos da responsabilidade civil". PRADO, Camila Affonso. Responsabilidade civil dos pais pelo abandono afetivo dos filhos menores. Dissertação (Mestrado pela Faculdade de Direito do Largo São Francisco da Universidade de São Paulo). 237 p. pp. 170-171. No mesmo sentido: "[a]ssim, perfeitamente possível a responsabilização dos pais pelos seus atos que prejudicarem seus filhos - lembrando-se, aqui, novamente que a referida responsabilidade também pode espraiar-se ao âmbito criminal, com a concretização da prática de delitos como os de abandono material (art. 244 do Código Penal), entrega de filho menor a pessoa inidônea (art. 245), abandono moral (art. 247); a supressão ou alteração de direito inerente ao estado civil de recém-nascido (art. 242), a sonegação do estado de filiação (art. 243), entre outros". FEDERIGHI, Wanderley José. $A$ responsabilidade civil dos pais. Dissertação(Mestrado pela Faculdade de Direito do Largo São Francisco da Universidade de São Paulo). São Paulo, 1997. 191p. p. 178.

304 "Do ponto de vista legal, o art. 159 do revogado Código de 1916 e o art. 186 do Código Civil vigente abrigam a hipótese. Ainda assim, a responsabilização dos pais parece causar estranheza, quando não repulsa, à sociedade, à comunidade jurídica". LIMA, Taisa Maria Macena de. "Responsabilidade civil dos pais por negligência na educação e formação escolar dos filhos: o dever dos pais de indenizar o filho 
imprescindível a avaliação da culpa para o nascimento da obrigação de indenizar os prejuízos ocasionados pela participação do menor em pesquisas clínicas.

Conforme dito, quando da análise das obrigações de meio, a constatação acerca da antijuridicidade da conduta se dá conforme um padrão objetivo, do homem médio, sendo que a avaliação da culpa deva ser enfocada sob um aspecto subjetivo, em que se leve em conta as próprias características pessoais, econômicas, sociais e intelectuais do autor do dano, bem como as circunstâncias concretas do caso em questão, para se afirmar a existência ou não do dever de indenizar.

Deve ser frisado que essa avaliação peculiar da culpa ganha especial relevo no âmbito da responsabilidade nas relações entre pais ou responsáveis legais e crianças ou adolescentes, exatamente porque nestas estão envolvidos muitos interesses, além daqueles meramente patrimoniais, especialmente o afeto $\mathrm{e}$ a necessidade patente de desenvolvimento do menor.

Desse modo, afirma-se uma presunção de afeto dos pais e responsáveis para com as crianças e adolescentes. Apenas naquelas situações limite em que reste demonstrada que a permissão de ingresso ou manutenção dos menores como sujeitos de pesquisa se deu por interesses obscuros, que não terapêuticos, ou em que se caracterize uma palpável negligência dos pais e responsáveis no cuidado das crianças e adolescentes, é que restará caracterizada a responsabilidade civil daqueles.

Necessário, nesse sentido, avaliar a situação sob este prisma da posição especial dos pais e responsáveis, para que se possa afirmar a existência da obrigação de indenizar os danos patrimoniais e, especialmente, morais causados. Uma responsabilização sem levar em conta os critérios mencionados pode acarretar uma desestabilização incontornável das relações familiares, o que pode gerar maiores danos aos menores que uma eventual negação do dever de reparação.

Importante ressaltar que o nexo causal entre a conduta permissiva de pais e responsáveis legais e os eventuais prejuízos ocasionados aos menores só estará caracterizado quando aqueles forem efetivamente conhecedores dos dados, inicialmente ou durante a pesquisa, que lhes possibilitem vislumbrar a real probabilidade de ocorrência de dano, ou mesmo o início de sua concretização.

prejudicado. In: PEREIRA, Rodrigo da Cunha (coord.). Afeto, Ética, Família e o novo Código Civil. Belo Horizonte: Del Rey, 2004. pp. 621-631. p. 628. 
Não basta afirmar que a autorização foi concedida, ou mantida, sem se demonstrar que os pais ou responsáveis tiveram conhecimento dos riscos envolvidos ou dos prejuízos causados. É óbvio que a não busca de informações por aqueles agentes, quando deveriam fazê-lo, consubstancia, da mesma forma, a existência do nexo causal e da consequente ilicitude de sua atuação.

Caso se reconheça a obrigação de indenizar aos pais e responsáveis legais do menor, deve-se, igualmente, priorizar a reparação "in natura" dos danos, especialmente aqueles de cunho moral, sendo imperiosa a busca de minimização dos traumas à saúde e à psique causados, restabelecendo a normalidade do processo de desenvolvimento das crianças e adolescentes afetados. O caminho, inegavelmente, pode ser árduo e longo, mas se mostra como o mais adequado ao atendimento dos ditames éticos, constitucionais e legais no que concerne à proteção dos menores ${ }^{305}$.

Todavia, em algumas situações nem sempre haverá cabimento para o modo de reparação acima referido, o que não impede a compensação pecuniária, ainda que imperfeita, a qual responda à demanda legal e social de proteção dos direitos da personalidade das crianças e adolescentes ${ }^{306}$. A mesma ressalva é pertinente à responsabilidade civil dos pesquisadores, patrocinadores instituição envolvidos na pesquisa clínica.

Portanto, não há como sustentar a irresponsabilidade dos pais e responsáveis pelos danos causados às crianças e adolescentes, sendo imprescindível que a análise sobre a adequação da conduta daqueles se dê mediante um enfoque cuidadoso, de proteção do melhor interesse da criança e do adolescente, evitando ao máximo a mera patrimonialização das relações familiares.

305 No mesmo sentido: COSTA, Maria Isabel Pereira. "Família: do autoritarismo ao afeto. Como e a quem indenizar a omissão do afeto? In: Revista Brasileira de Direito de Família. Ano VII, n 32, out./nov. 2005, Porto Alegre: IOB Thomson, 2005. pp. 20-39. p. 37.

306 "É certo que a aplicação da responsabilidade civil a situações como a presente nos leva a pensar se haveria uma funcionalidade perfeita entre os institutos. A priori, entendemos que não, uma vez que a forma de ressarcimento é patrimonial. Entretanto, diante do aparecimento de novos interesses dignos de tutela, deve-se buscar formas de proteção pelo ordenamento jurídico. Por enquanto, o instrumento que encontramos para tutelar interesses existenciais, como o que expusemos [abandono afetivo], é a responsabilidade civil. Talvez, encontremos meios mais funcionais de proteção e promoção à criança e ao adolescente, de modo a resguardar seu crescimento saudável, para incentivar a efetivação do conteúdo da autoridade parental, como um compromisso ético e jurídico dos pais”. TEIXEIRA, Ana Carolina Brochado. "Responsabilidade civil e ofensa à dignidade humana". In: Revista Brasileira de Direito de Família. Ano VII, no 32, out./nov. 2005, Porto Alegre: IOB Thomson, 2005. pp. 138-158. p. 155. 


\subsection{Nexo causal}

\subsubsection{Reflexões gerais e problemática}

A noção de causalidade possui duas funções: determinar a autoria de um dano e a consequente responsabilidade e fixar a extensão do prejuízo reparável ou indenizável ${ }^{307}$. No caso das pesquisas clínicas, em razão do comando trazido pela Resolução 196/96, esta segunda tarefa não será objeto de maiores debates, tendo em vista a imposição de que sejam reparados todos e quaisquer danos sofridos pelo sujeito em razão de sua participação no estudo, não se olvidando as observações efetuadas no item anterior.

De qualquer maneira, ordinariamente, a questão do nexo causal perturba a doutrina civilista desde o século XIX. Há uma patente dificuldade em se estabelecer de que forma um determinado acontecimento pode ser tido como causa/consequência, juridicamente relevante, de outro ${ }^{308}$.

Geralmente, não é possível observar de maneira fácil apenas a existência de um fato específico que se demonstre como razão direta e suficiente de um determinado prejuízo. A complexidade do mundo concreto acaba por determinar, na maior parte das vezes, situações em que se nota a presença de vários fatos inicialmente pertinentes à produção de um certo resultado, razão pela qual se fala em concausas, sucessivas ou simultâneas ${ }^{309}$.

Com a finalidade de solucionar o problema, várias teorias jurídicas foram construídas com vistas a apontar os critérios que permitam imputar a um determinado fato a qualidade de causa de outro acontecimento relevante ao direito, sendo as principais delas a da equivalência das condições, a da causalidade adequada e a da causalidade imediata.

307 LORENZETTI, Ricardo Luis. ob. cit. p. 110.

308 "Na verdade, temos que considerar dois momentos na averiguação do nexo causal. O primeiro diz respeito ao fato, ato ou omissão que venha a ser a causa do dano (dano evento), ou seja, o liame que aí existe entre a conduta lícita ou ilícita e o dano. É o nexo causal físico, material, natural ou de fato, muito próximo das ciências naturais. Porém, num segundo momento, devemos averiguar quais as conseqüências prejudiciais (econômicas ou pessoais), à vítima do dano que podem dar lugar ao pedido de indenização (dano prejuízo). Nessa etapa deveremos precisar a causalidade jurídica, que é o elemento hábil a elucidar quais atores e quais fatos serão considerados pelo Direito, e, a partir daí, dar os limites dos danos ressarcíveis". LOPEZ, Teresa Ancona. Nexo causal e produtos potencialmente nocivos. A experiência brasileira do tabaco. São Paulo: Quartier Latin, 2008. p. 23.

309 GONÇALVES, Carlos Roberto. ob. cit. p. 585. 
Para a primeira, abraçada com as devidas adaptações por nosso Código Penal $^{310}$, qualquer condição que haja concorrido para o dano é considerada causa, permitindo um regresso ao infinito, abarcando como motivo gerador situações naturais que, por um critério de justiça, não poderiam receber tal qualificativo jurídico, sob pena de se imputar a responsabilidade pelos prejuízos a pessoas que em nenhum momento tiveram ligação com o fato analisado.

A segunda, da causalidade adequada, considera como causa o fato suficiente por si à produção do resultado. Deve-se analisar a cadeia causal através de uma aferição hipotética e verificar quais seriam, isoladamente, através de um juízo de razoabilidade sobre o que normalmente ocorre, os fatos mais adequados à produção do resultado danoso $^{311}$, eliminando os acontecimentos tidos, inicialmente, como condições possíveis, mas que não são aprovados por tal avaliação.

A terceira, para boa parte dos autores adotada pelo Código Civil, em seu artigo 403, denominada da causalidade direta e imediata, aduz, em sua forma básica, que causa jurídica é apenas aquele fato que se liga de modo imediato ao prejuízo, sem a incidência de qualquer outra condição sucessiva. Não aquele fato mais próximo temporalmente será considerado como causa, porém o mais determinante para o nascimento do dano. ${ }^{312}$.

Não é intenção aprofundar-se no estudo dessas teorias, bastando reconhecer a extrema dificuldade em se precisar, claramente, e nas situações mais ordinárias, o nexo causal existente entre dois acontecimentos.

Como visto, a experimentação clínica é calcada, basicamente, na incerteza das consequências que de um tratamento estudado podem advir. Nesse cenário, nem sempre é possível definir claramente a ligação entre eventuais prejuízos à saúde sentidos pelos sujeitos e o objeto do ensaio em curso.

Além disso, é muito comum, inclusive no que tange aos medicamentos e outros produtos já devidamente testados e comercializados, que os danos tenham o seu aparecimento retardado no tempo em razão da necessidade de cumulação da substância no organismo, ou mesmo de certas afetações que somente com o decurso de período dilatado se mostrem efetivamente danosas. Tal quadro é agravado no âmbito de tratamentos em

${ }^{310}$ GARCIA, Basileu. Instituições de Direito Penal, v. I, tomo I. $7^{\mathrm{a}}$ ed. rev. e atual. São Paulo: Saraiva, 2008. p. 296.

311 CAVALIERI FILHO, Sérgio. Programa de responsabilidade civil. p. 49.

${ }^{312}$ Idem. p. 52. 
teste exatamente em razão de os prejuízos potenciais, diretos ou conexos, serem pouco ou mal conhecidos. Outras causas concomitantes podem estar relacionadas ao evento, como predisposições genéticas, por exemplo. Importante realçar que, para a medicina, é um conjunto de causas, em diferentes graus, que leva às consequências, danosas ou benéficas $^{313}$.

Diante dessa realidade, torna-se ainda mais dificultoso determinar a efetiva ligação entre certos danos e a participação do sujeito em um ensaio clínico. As noções comuns acerca do nexo causal entre a conduta e os prejuízos sofridos pelos sujeitos de pesquisa não satisfaz totalmente a necessidade de reparação integral dos danos. Na maioria das vezes, é preciso frisar, não é possível discernir um liame direto, facilmente demonstrável. Tendo em vista a dificuldade apresentada é que surgem novas teorias, buscando afastar a situação de incerteza quanto à existência de nexo causal em certos casos e possibilitando uma justa reparação dos prejuízos sofridos.

\subsubsection{Teoria da perda de uma chance.}

A teoria da perda de uma chance surge na França, na década de 1960, por criação jurisprudencial $^{314}$, com o intuito de identificar, em certos casos, o dano do paciente como a eliminação de certa probabilidade de obtenção de um melhor resultado, causada por conduta culposa do profissional médico durante a realização de determinado tratamento ou procedimento. De qualquer forma, em sua feição original, a avaliação da responsabilidade do agente dependerá da verificação de culpa, sendo do tipo subjetiva.

De maneira inicial, deve-se explicar que a teoria comentada no presente item possui, de acordo com a doutrina majoritária, duas vertentes principais bem definidas e com âmbitos e modos de aplicação distintos, visto serem embasadas em elementos diversos da responsabilidade civil.

A primeira, denominada clássica, trabalha com o conceito de dano incerto, e

${ }^{13}$ LORENZETTI, Ricardo Luis. ob. cit. p. 116.

314 "Nos casos de aplicação dessa teoria, o médico, embora agindo com culpa, não é a rigor, o causador do dano. A relação de causalidade que se estabelece entre a culpa do médico e o dano do paciente não é, portanto, natural, mas sim estritamente jurídica. Não há efetivamente um dano, e sim a perda da possibilidade de alguém auferir alguma vantagem". In: ROSÁRIO, Grácia Cristina Moreira do. "A perda da chance de cura na responsabilidade médica". pp. 167-187. In: Revista da Escola da Magistratura do Estado do Rio de Janeiro. v. 11, n 43. Rio de Janeiro, 2008. p. 170. 
nexo causal determinado, quando não se pode precisar se a vítima obteria ou não certa vantagem, mas se pode atribuir a exclusão desta possibilidade a uma conduta do infrator. É modalidade de danos emergentes. O dano é a privação de uma oportunidade de obter um êxito, e não os benefícios que se deixou de lograr em razão do não alcance do sucesso ${ }^{315}$.

Já a segunda centra-se na análise do nexo causal indireto, ou causalidade parcial, baseando-se em probabilidades que permitam imputar a ocorrência de certo dano, ou seja, a não obtenção de cura, ou outro benefício, a um determinado agente ${ }^{316}$. Apesar de ambas serem aplicadas ao âmbito da responsabilidade civil médica ${ }^{317}$ (mesmo no caso de pesquisas clínicas), a análise aqui focada se dará pela segunda variação da teoria.

Isso porque, como tratado, os procedimentos médicos, de uma maneira geral, revestem-se de um alto grau de complexidade, estando sujeitos a inúmeros fatores imponderáveis decorrentes tanto das características dos pacientes, quanto das especificidades do meio que os cercam, existindo uma verdadeira zona aleatória com influência decisiva na consecução dos objetivos esperados. Em outras palavras, pode-se dizer que um mesmo procedimento pode produzir diferentes resultados se aplicado em pessoas diversas ou ainda na mesma pessoa, mas em ambientações diferentes.

Por tais motivos, quando da ocorrência de um dano ao paciente, ou mesmo de não atendimento de um fim proposto, nem sempre é possível identificar um vínculo direto entre uma conduta perpetrada pelo médico e tal prejuízo, podendo tal liame somente ser demonstrado de acordo com um sistema de probabilidades.

O esquema clássico de responsabilização, nesses casos, infelizmente não possibilita a devida responsabilização do agente causador de um ato ilícito, uma vez que nesse modelo exige-se a configuração de um inequívoco nexo causal entre a ação e o

315 SAVI, Sérgio. Responsabilidade civil por perda de uma chance. São Paulo: Atlas, 2006. p. 102.

316 Para uma abordagem completa do tema, cf. a excelente obra de Rafael Peteffi da Silva, Responsabilidade civil pela perda de uma chance: uma análise do direito comparado e brasileiro. São Paulo: Atlas, 2007.

317 Rute Teixeira Pedro afirma que no âmbito das relações médicas a teoria da perda de uma chance é utilizada de maneira equivocada, no sentido de criar uma presunção de nexo causal [causalidade parcial], quando haja uma conduta culposa do médico e um dano ao paciente, sem que seja possível efetivamente determinar o liame entre estes fatos. "Então, o julgador, face às dúvidas sentidas no apuramento do nexo causal entre o acto do médico e o resultado produzido, opta pela solução de presumir essa causalidade, diminuindo, simultaneamente, de forma proporcional, o montante dos danos ressarcíveis, em função da intensidade das dúvidas sentidas. A aplicação da teoria da perda de uma chance, nos casos considerados, equivaleria, portanto, no plano prático, segundo alguns Autores, à existência de uma presunção de causalidade, que seria introduzida pelo órgão jurisdicional, com um contrapeso ou um mecanismo de salvaguarda". ob. cit. p. 286. 
dano $^{318}$. São casos, por exemplo, em que o médico deixa de aplicar certa técnica que poderia, com uma considerável, ainda que não total, probabilidade, provocar a cura do paciente.

Está-se, inegavelmente, no âmbito da responsabilidade contratual, na medida em que o médico deverá empregar todos os meios necessários para a obtenção de uma cura, sendo que em eventual e considerável perda de uma chance por conduta culposa do agente caracterizar-se-á um verdadeiro ilícito negocial.

É necessário frisar também que não se cogitam possibilidades vagas, mas sim de certos resultados, devidamente comprovados cientificamente, que poderiam ser auferidos caso a conduta do agente tivesse sido efetuada de maneira diligente e não culposa $^{319}$.

A probabilidade do liame entre o prejuízo e a conduta do agente deve ser real, e em grau elevado, ainda que não absoluto. Probabilidades pequenas não permitem a aplicação dessa teoria e a consequente responsabilização do profissional médico. A perda da oportunidade há de ser concreta ${ }^{320}$. A chance de cura deve possuir um sólido grau de probabilidade de ocorrência, caso o agente tivesse tomado outra conduta perante os fatos $^{321}$.

Observa-se que tal teoria possui estrita ligação com a identificação das obrigações médicas, já que se analisa exatamente a adequação e correção dos procedimentos adotados pelos profissionais no exercício da atividade e as consequências futuras que eliminam certa chance de obtenção de cura.

A indenização da vítima será integral, de acordo com o dano imputado ao

318 "Atualmente, com o crescente número de demandas judiciais envolvendo o instituto da responsabilidade civil, notou-se que em determinados casos, ainda que se constatasse a ocorrência de uma conduta culposa do agente e um dano efetivo para a vítima, não era possível demonstrar o nexo de causalidade entre ambos, restando o lesado sem o devido ressarcimento. GONDIM, Glenda Goçalves. "Responsabilidade Civil: teoria da perda de uma chance". Revista dos Tribunais. v. 840, ano 94, out. 2005. pp. 11-33. p.11.

319 "Através desta proposta, pacientes sofrem um dano quando se pode constatar, por meio de cálculos de probabilidades, que eles perderam uma chance de recuperar sua boa saúde. (Under this proposal a plaintiff suffers damage when they can establish on the balance of probabilities, that they lost a chance of recovery of better health)". CORBETT, Angus. "A reformulation of the right to recover compensation for medically related injuries in the tort of negligence”. In: The Sydney Law Review. v. 19, n 2. Sydney, june 1997. pp. 141-178. p. 160.

320 KFOURI NETO, Miguel. Responsabilidade civil do médico. p. 67.

3217 "Há que se distinguir os casos de dano futuro palpável de evento hipotético, este último não indenizável. O juiz só poderá aplicar a perda de uma chance quando verificar a existência do vínculo de causalidade,e mais, quando esse vínculo for forte o suficiente para proporcionar ao requerente sucesso na demanda". E mais adiante, completa a Autora: "[a] chance deve ser séria e provável. É rejeitada a indenização de mera suposição”. ROSÁRIO, Grácia Cristina Moreira. ob. cit. p. 174. 
profissional de saúde ${ }^{322}$, salvo situações específicas atinentes ao sistema geral de responsabilidade do Código Civil, como nos casos em que a culpa do agente for de importância reduzida, permitindo a diminuição equitativa do ressarcimento ${ }^{323}$. Nos casos ditos clássicos de incidência da teoria da perda da chance, ao revés, eventual indenização a ser suportada pelo agente em face da vítima será fixada proporcionalmente ao valor que seria obtido se se perdessem todas as chances ${ }^{324}$.

Desse modo, o que fica patente é que a teoria da perda de uma chance, sob o enfoque estudado, busca efetivar a tutela jurídica de situações danosas em que não é possível se identificar um prejuízo imediatamente ligado a uma conduta do agente médico de acordo com o sistema clássico da responsabilidade civil. Procura-se ressarcir aquele dano que se consubstancia na perda de uma possibilidade real de obtenção de determinado resultado positivo. Perda esta imputada, por um juízo de probabilidade, à conduta culposa do profissional.

No âmbito das pesquisas clínicas também é cabível, a princípio, a invocação da teoria destacada. Uma importante adaptação deve ser feita, na medida em que, nesta seara, a responsabilidade do pesquisador/patrocinador é objetiva, razão pela qual a importância de sua conduta para a não obtenção de certo resultado será avaliada independente de ter agido culposamente ou não. Tal constatação não desnatura a aplicação da teoria em análise, tendo em vista que se centra não no elemento subjetivo, mas no elemento objetivo do nexo causal.

Concretizando o quanto abstratamente definido, imagina-se uma situação em que o sujeito de pesquisa, portador de certa doença, recebe um novo tratamento, ainda em estudo, que possivelmente seria tão eficiente, com menos efeitos adversos, do que aqueles já existentes. Nos trâmites iniciais do ensaio em fase III, mostra-se, até aquele momento, inócua a substância pesquisada, havendo um agravamento da doença do sujeito. $\mathrm{O}$ pesquisador continua realizando a pesquisa, acreditando, com base nos dados colhidos nas fases anteriores, que a patologia do sujeito será solucionada, sem administrar os medicamentos ordinários. A doença se agrava, tornando-se incurável, o que poderia ser

\footnotetext{
322 SILVA, Rafael Peteffi. ob. cit. p. 133.

323 Artigo 944, parágrafo único.

$324\urcorner$ “A jurisprudência italiana trata da quantificação da indenização da perda da chance da seguinte forma: reparte o valor do resultado útil esperado e sobre ele faz incidir o percentual de chances que o lesado possuía antes do ilícito ocorrido”. ROSÁRIO, Grácia Cristina Moreira do. ob. cit. pp. 167-168.
} 
evitado, com um grau de probabilidade considerável caso se realizasse o outro tratamento. Em contrapartida, outro paciente-sujeito, na mesma situação, acaba por ser curado de sua doença com o novo tratamento.

No primeiro caso proposto, não há como se afirmar, de maneira totalmente segura, que a não cura se deu por conduta do médico, tampouco que sua atuação foi culposa, na medida em que outra pessoa, na mesma situação, teve o seu problema contornado, como se vê no segundo caso. Entretanto, existe a probabilidade elevada de que o sujeito, se o pesquisador tivesse interrompido a pesquisa e administrado o medicamento cientificamente consolidado, conseguisse obter a cura. Pode-se afirmar, portanto, que a conduta do pesquisador significou a perda de uma chance de cura, podendo este ser responsabilizado pelo dano produzido no hipotético sujeito do primeiro caso, responsabilidade esta que se estende ao patrocinador, ao promotor e à instituição de pesquisa, conforme a Resolução 196/96.

\subsubsection{Teoria da responsabilidade civil pelo incremento dos riscos}

A aplicação da teoria da perda de uma chance é restrita apenas à solução das situações em que a conduta do profissional eliminou chances de cura. Não se cogitam outros tipos de dano que, mesmo produzidos em momento bastante posterior ao procedimento realizado, podem ser ligados, de acordo com um sistema probabilístico sólido, às condutas dos médicos ou pesquisadores/patrocinadores de uma pesquisa.

Por essa razão, deve ser buscado o enquadramento da mesma questão sob uma nova perspectiva, de enorme relevância para o âmbito dos testes clínicos, terapêuticos ou não, haja vista que os prejuízos advindos não estarão necessariamente ligados a eventual não obtenção de cura de uma determinada patologia.

Conforme visto, por ser a medicina uma ciência sujeita a inúmeros fatores variáveis, uma determinada patologia pode demorar um razoável tempo para se manifestar, sendo possível que, em uma eventual investigação sobre esta, revele-se que tal problema possui uma considerável probabilidade de ser decorrente de certo tratamento médico ou pesquisa clínica, realizados em momento anterior.

Importante observar que, no mesmo sentido da teoria da perda de uma chance, o nexo causal entre o dano suportado no futuro e a conduta do médico ou pesquisador em 
momento anterior não segue um esquema claro de certeza, baseando-se em probabilidades relevantes, que permitam o nascimento da responsabilização do agente, ainda que não total $^{325}$.

E poderá tal dano ser, por exemplo, o aumento da probabilidade de ocorrência de uma patologia, cuja ocorrência poderia ser imputada à pesquisa realizada. Em que pese a doutrina analisada referenciar a aplicação da teoria aos casos de responsabilidade subjetiva, por se tratar de uma abordagem que visa a relativizar a verificação do nexo causal, não se enxerga óbice à sua incidência, igualmente ao que foi dito no que concerne à teoria da perda de uma chance, também aos casos de responsabilidade sem culpa.

Nessas hipóteses, fala-se de um incremento dos riscos à ocorrência de determinado prejuízo concreto ao paciente, ocasionado por conduta do pesquisador. A consequência em si não pode ser imputada totalmente e diretamente ao profissional ${ }^{326}$.

Apesar da conduta danosa ser o incremento dos riscos dentro de um contexto de determinado procedimento médico ou científico, nenhuma responsabilização é cabível enquanto os riscos forem apenas potenciais, ou seja, enquanto não haja um concreto prejuízo ao paciente ${ }^{327}$, conferindo a essa teoria, quanto ao dano, um grau de segurança bem mais elevado do que aquele decorrente da teoria da perda de uma chance em sua

325 'Sem dúvida, a formação do nexo causal e sua prova devem fazer parte da responsabilidade 'in concreto', ou seja, do exame caso a caso, com a prudência do juiz, porque a certeza absoluta raramente existe e a probabilidade para levar a fazer alguém responder por perdas e danos deve ser quase uma certeza, A verossimilhança talvez seja o conceito mais adequado ao caso. De outro lado, a diferença de postura no apreciar as provas vai aparecer nos casos com fundamento na culpa e no risco. A situação é muito mais favorável à vítima no caso de risco da atividade, quando havendo o fato e o dano há lugar para indenização, e somente as excludentes legais poderão atuar sobre o nexo". LOPEZ, Teresa Ancona. Nexo causal e produtos potencialmente nocivos. A experiência brasileira do tabaco. p. 34.

326 "Neste quadro, o dano é definido como a transformação de um risco particular em prejuízo. Isto significa que o efeito deletério suportado pelo paciente é uma manifestação do dano, mas não o dano em si. O dano é a transformação do risco específico, cuja prevenção é objeto da obrigação do médico, em prejuízo concreto. Não há, portanto, nenhuma base para ação de responsabilização até que o risco específico não se concretize em prejuízo. Esta, não é baseada na indenização do montante total do prejuízo sofrido pelo paciente. Na realidade, o objetivo da ação é reparar aquela parcela de prejuízo concreto que representa o incremento do risco de ocorrência deste efeito particular pelo qual o médico é responsável. (Within this framework the damage is defined as the transformation of a particular risk of harm into actual harm. This means that the actual harm sustained by the plaintiff is the manifestation of the damage but is not the damage itself. The damage is the transformation of the specific risk of harm, the prevention of which is object of the defendant's duty owed to the plaintiff, into actual harm. There is therefore no cause of action until the specific risk of harm is transformed into actual loss. Further, this cause of action is not based upon recovery of the total amount of the actual harm suffered by the plaintiff. Rather the cause of action is to recover that portion of the actual loss which represents the increased risk of occurrence of that particular loss for which the defendant is responsible)". CORBETT, Angus. ob. cit. p. 164.

327 Já se discute, ainda que de maneira tímida, a possibilidade de responsabilização apenas pelos riscos criados à produção de um efeito adverso, prévia e independentemente da ocorrência deste. In: SILVA, Rafael Peteffi da. ob. cit. pp. 123-133. 
vertente clássica ${ }^{328}$.

Além disso, a indenização devida será fixada de acordo com um cálculo proporcional entre as chances totais de ocorrência daquele dano e o percentual de incremento de riscos imputável à conduta culposa do médico responsabilizado.

Discorda-se parcialmente da teoria ora estudada, tendo em vista que o prejuízo em si está totalmente produzido, apenas não se pode determinar, com grau de certeza exauriente, que a participação do sujeito na pesquisa consubstancia sua causa. Se existe uma probabilidade relevante de que esta relação causa-efeito seja real, em razão da exposição da vítima a riscos, está a se criar uma verdadeira presunção de sua ocorrência. Isso passa a ser o motivo pelo qual se deve entender caracterizado o nexo causal, bem como a reparação ou indenização total do dano ${ }^{329}$. Não existem concausas, no presente caso, que justifiquem a adoção da responsabilização parcial.

Dessa forma, a teoria de incremento dos riscos procura se valer de um esquema de probabilidades a fim de proteger o interesse dos pacientes vítimas de um prejuízo cuja ocorrência não possa ser diretamente imputada à conduta do pesquisador, mas em que a participação do sujeito na pesquisa tenha incrementado, de maneira considerável, os riscos de produção de resultado indesejável.

Em ambas as teorias analisadas, a demonstração do liame é necessária,

$328\urcorner$ "Esta abordagem não é, portanto, dependente de um conhecimento objetivo sobre se o paciente teria ou não se recuperado SE o hospital tivesse efetuado um diagnóstico correto. Ela se liga à razoabilidade da avaliação de riscos feita pelo prestador de serviços médicos ao tempo da decisão sobre a realização de um determinado tratamento. Neste sentido, o dever de cuidado é definido com referência ao conhecimento adequado do profissional de saúde quando da ação ou omissão relevante. O modelo de responsabilidade é do tipo relacional, porque é caracterizado de acordo com a percepção própria do médico e do paciente sobre os riscos e prejuízos. (This approach is not therefore dependent upon objective knowledge about whether or not the plaintiff would have recovered IF the hospital had made a correct diagnosis. It is dependent upon a reasonable health care provider's own assessment of the risk at the point in time when the decision is made to proffer a particular form of medical treatment. In this sense the duty of care is defined with reference to a reasonable health care provider's state of knowledge at the time of the relevant act or omission. The model of responsibility is a relational model of responsibility because it is characterized with reference to the defendant's and the plaintiff's own perceptions of the risks and harms)". CORBETT, Angus. ob. cit p.168.

329 "A jurisprudência [argentina] há muitos anos e até a reforma atual, sustenta que basta a prova do contato do trabalhador com o ambiente laboral ou, explicitando, a fonte de risco, e a presença desses agentes, para se ter como demonstrado o nexo causal. Em outros casos, de transmissão de enfermidades, a solução foi encontrada de um modo simples, argumentando-se que provado o contato com a coisa, em termos genéricos, dá-se por demonstrada a adequação. (La jurisprudencia [argentina] desde hace varios años y hasta la reforma actual, ha postulado que basta la prueba del contacto del obrero con el ambiente laboral o, si quiere, la fuente de riesgo, y la presencia de esos agentes, para tener por demostrado el nexo causal. En otros casos de transmisión de enfermedades la solución se encontró de un modo simple, argumentando que probado el contacto con la cosa, en términos genéricos, se da por demostrada la adecuación)". LORENZETTI, Ricardo Luis. ob. cit. p. 130. 
somente se afastando de um juízo de certeza, muitas vezes inalcançável e criador de inúmeras injustiças, afinal deixa danos sem a devida reparação, para se aproximar de uma avaliação calcada na observação daquilo que concretamente acontece, do que seja razoável e provável esperar como resultado de um fato anterior.

O Direito, como já se viu no decorrer do presente trabalho, não se iguala ou se submete às ciências físicas e naturais. Ele atua de acordo com um critério de justiça, intermediada a aplicação da norma aos fatos pelos valores eleitos como de proteção necessária.

A vítima deve provar, de alguma forma, ainda que não exaustiva, um mínimo razoável (grau considerável de probabilidade) de pertinência entre o tratamento em estudo ao qual foi submetida e os prejuízos alegados. Caso se desincumba da tarefa com sucesso, cria-se uma presunção ${ }^{330}$ de responsabilidade, calcada na probabilidade séria de existência do nexo causal. Se inexistirem indícios seguros, aferidos de acordo com as especificidades da situação litigiosa posta em análise, que demonstrem a real chance dos danos terem sido ocasionados pela participação do sujeito na pesquisa, não há que se referir, portanto, à responsabilidade do pesquisador/patrocinador, instituição e mesmo pais ou responsáveis legais, com as devidas diferenças.

\subsection{Suspensão e perda do poder familiar}

Como vimos amplamente ao longo deste trabalho, a atuação dos pais no exercício do poder familiar deve se dar sempre com vistas ao atendimento, de modo prioritário, ao melhor interesse das crianças e dos adolescentes, buscando a proteção integral de seus direitos garantidos constitucionalmente.

Quando se está diante de uma disfunção na realização dessa tarefa, em que haja um efetivo prejuízo dos interesses dos filhos por conta de uma conduta indesejável dos genitores, ou mesmo de situações excepcionais em que a ausência de um dos pais, ou de

\footnotetext{
${ }^{330}$ Carolina Bellini Arantes de Paula, defende, contrariamente, que "[t]ais soluções [presunção do nexo causal], contudo, afrontam, ainda que justificadas pela nobre defesa do meio-ambiente e do consumidor, os princípios básicos da imputação da responsabilidade civil objetiva, o que acarreta insegurança jurídica. A demonstração efetiva do nexo causal, mitigada nas atividades nucleares, é essencial à imputação da responsabilidade civil objetiva, sob pena de aplicar-se à já criticada responsabilidade automática.".ob. cit.. p. 53.
} 
ambos, possa acarretar, igualmente, danos aos menores, é que se refere à suspensão ou perda do poder familiar.

Observa-se, desde já, que exatamente para o cumprimento de escopo protetivo, a ser verificado no caso concreto específico, é que as hipóteses autorizadoras das medidas abaixo comentadas não são taxativas ${ }^{331}$.

De início, cumpre ressaltar que a suspensão ocorre de maneira temporária, buscando estabelecer uma sanção ao genitor faltoso, mas que lhe possibilite o retorno ao exercício do poder familiar. O período de suspensão serve como uma oportunidade de atenuar os eventuais prejuízos sofridos pela prole, os quais poderiam ser agravados com a presença do pai afastado, bem como para que este proceda a uma reflexão sobre seu modo de agir, para que os eventos prejudiciais não reincidam. É de se frisar que o principal objetivo da suspensão do poder familiar é resguardar os interesses dos filhos, sendo imposta pelo tempo necessário à efetivação dessa finalidade.

Na suspensão, o genitor faltoso acaba sendo destituído, não definitivamente, de todas ou algumas prerrogativas originadas do poder familiar e relativamente a algum ou todos os filhos, conforme a exigência do caso concreto ${ }^{332}$.

Trata-se de medida imposta judicialmente aos pais, de acordo com as situações previstas no artigo 1.637, “caput” c.c., parágrafo único, do Código Civil, quais sejam: abuso de autoridade, faltando os pais aos deveres a estes inerentes, ou arruinando os bens dos filhos; condenação criminal por sentença irrecorrível à pena que exceda a dois anos de prisão. Já nos artigos 22 c.c. 24 , do Estatuto da Criança e do Adolescente, há a referência às situações de não cumprimento dos deveres de guarda, de sustento e de educação.

Constata-se, na realidade, que as hipóteses previstas na lei especial já estão enquadradas naquelas trazidas pela lei geral, demonstrando-se em ambas a preocupação em se proteger, de maneira integral, o estado dos menores como pessoas em desenvolvimento, que requerem cuidados especiais.

De acordo com o dispositivo em questão, o Juiz determinará, em processo

${ }^{331}$ SCAFF, Fernando Campos. "Considerações sobre o Poder Familiar". p. 580.

${ }^{332}$ COMEL, Denise Damo. ob. cit. p. 264. Esta questão não é pacífica em doutrina, existindo entendimentos de que, por uma questão de punição, se suspenso o poder familiar em relação a um dos filhos, esta se estenderá aos demais: "[a]ssim, além da finalidade punitiva, [a destituição do poder familiar] possui também escopo protetivo, na medida em que afasta o filho da convivência com o pai ou a mãe que coloca em perigo a sua integridade física e psíquica. Em razão da gravidade da violação dos direitos e deveres do poder familiar, trata-se de sanção obrigatória, irreversível e extensiva a toda a prole, ainda que o ato tenha sido praticado contra apenas um dos filhos". PRADO, Camila Affonso. ob. cit. p. 133. 
contraditório próprio, a medida que mais se coadune com a proteção dos interesses do menor e de seus haveres, o que pode redundar na suspensão do poder familiar referida ${ }^{333}$. Qualquer parente, o Ministério Público ou outra pessoa que tenha legítimo interesse ${ }^{334}$ podem requerer ao Juiz a adoção do ato em comento.

Nota-se que o abuso de autoridade, hipótese justificadora cuja análise interessa ao presente trabalho, pode ser entendido como qualquer ação ou omissão dos pais que, desbordando dos deveres ínsitos ao conteúdo do poder familiar, tragam aos filhos reais prejuízos, sejam eles de natureza patrimonial, física, psicológica ou moral, revelando um efetivo descumprimento do princípio base da relação familiar em comento: a conduta sempre voltada à garantia do desenvolvimento saudável da criança e do adolescente.

Além disso, não é necessário que a ação ou omissão dos genitores tenha sido realizada de forma dolosa ou culposa, levando-se em conta que, como delineado, a imposição da suspensão do poder familiar tem um caráter mais protetivo aos interesses do menor que propriamente sancionatório aos pais ${ }^{335}$.

Não obstante, deve-se tomar cuidado extremo no trato do assunto, evitando que a existência de qualquer desvio plenamente justificável se transforme em pretexto para imposição do gravame em comento aos pais ${ }^{336}$.

Ademais, não se pode olvidar que a suspensão do poder familiar, em última análise, impede o desejável e necessário convívio entre pais e fillhos, o que pode se mostrar muito mais danoso em relação à manutenção dessa relação, ainda que ocorrido algum tipo de conduta desviada.

Há que se apontar, também, que a sanção traz prejuízos aos próprios pais, pois, na maior parte das vezes, a quebra da relação com os filhos representa um dano deveras grave. Isso até mesmo pode representar um fator negativo à imagem dos genitores perante a sociedade e que pode acarretar sérias consequências deletérias à vida pessoal dos

${ }^{333}$ O artigo 24, do Estatuto da Criança e do Adolescente, traz regra semelhante, reforçando a necessidade de processo judicial para o decreto da suspensão do poder familiar.

334 Esta última hipótese tem previsão no artigo 155, do Estatuto da Criança e do Adolescente.

335 COMEL, Denise Damo. ob. cit. p. 272.

336 "É claro que o princípio da autonomia da família não é absoluto; é cabível a atuação do Estado, mas esta atuação deve ser supletiva. Para tanto, o Estado planeja e organiza sistema corretivo-repressivo que só é acionado a fim de atender a situações de crise no ambiente familiar. O art. 1.635 do Código Civil de 2002, ao enumerar hipóteses de perda do pátrio poder, autoriza a intervenção do Estado na entidade familiar. Em dadas circunstância, a presença do Estado é tão salutar quanto necessária; em outras situações, a interferência do Estado pode ser nociva, revestindo-se de feição policialesca". LIMA, Taisa Maria Macena de. ob. cit. p. 627. 
próprios menores.

Em suma, o que se deseja com o alerta é ponderar que a suspensão do poder familiar cuida de atitude bastante complexa, devendo a conveniência de sua imposição ser analisada sempre em razão do atendimento do melhor interesse dos menores ${ }^{337}$, sem se olvidar, contudo, que, do outro lado da relação, encontram-se pessoas suscetíveis a falhas e passíveis de sofrer reais prejuízos.

Aliás, todas as ressalvas aqui feitas se coadunam com a necessidade já afirmada de que se realize um processo judicial para efetivação da medida, dando plena oportunidade aos pais de se manifestarem, bem como conferindo ao Juiz amplos poderes probatórios.

A autoridade judicial não se limita às declarações contidas nos autos. Ela deve buscar o alcance da chamada verdade real, transcendendo a mera tarefa de imposição de uma sanção a fim de alcançar o sentido de resguardar, da melhor forma possível, os direitos infanto-juvenis envolvidos.

O cabimento da suspensão total do poder familiar, ou mesmo parcial, isto é, de algumas prerrogativas, dependerá do caso concreto posto sob a análise do Magistrado, de forma que lhe caiba analisar qual é a medida mais adequada e qual deve ser o grau de intensidade ${ }^{338}$ a ser aplicado. Nada impede, por exemplo, de o Juiz determinar um acompanhamento psicossocial dos pais ou até mesmo uma simples advertência a eles, em que chame atenção para os erros cometidos e à patente necessidade de que sejam corrigidos de modo breve e eficiente.

Em relação à perda do poder familiar, trata-se da medida mais grave que pode ser imposta aos pais faltosos no exercício da responsabilidade que devem assumir, já que significa a inabilitação completa e permanente para a função que a lei lhes concedia em relação ao filho que tenha sofrido as consequências do desvio cometido.

As hipóteses exaustivas que justificam a perda do poder familiar estão previstas

\footnotetext{
337 "Procura-se, em regra, manter a criança e o adolescente em sua família de origem, que é a encarregada da integração social primária daqueles. Unicamente em casos -limites, previstos em lei, é que se permitirá como que o afetamento do poder familiar. Todavia, mesmo na hipóteses extrema de afetamento do poder familiar, assegurar-se á aos pais inestimável cautela legal, isto é, a decretação da perda ou suspensão do poder familiar dependerá de decisão judicial, onde se assegure o procedimento contraditório, entendendose este, inclusive, como a possibilidade jurídica de os pais interessados se valerem do princípio da ampla defesa, sem a observância do qual faleceria o contraditório". p. 125. ANDRADE, Romero de Oliveira. $o b$. cit. p. 125.

${ }^{338}$ COMEL, Denise Damo. ob. cit. p. 280.
} 
no artigo 1.638, do Código Civil, sendo elas: o castigo imoderado dos filhos; abandono destes; prática de atos contrários à moral e aos bons costumes; incidência reiterada nas faltas previstas como circunstâncias motivadoras da suspensão.

Igualmente, a imposição de tal gravame depende de ato judicial, precedido de um processo em que sejam efetivamente garantidos o contraditório e a ampla defesa. Existe, ainda, a hipótese prevista no artigo 92, do Código Penal, em que haverá perda do poder familiar, necessariamente, como efeito da sentença condenatória, nos casos de crime doloso, punido com reclusão, cometido por parte do genitor contra o filho.

Interessa ao conteúdo deste trabalho, definir os contornos básicos das hipóteses de abandono dos filhos, consideradas como práticas de atos contrários à moral e aos bons costumes. Quanto à reiteração das faltas previstas como ensejadoras da suspensão do poder familiar, exatamente porque já definidas, basta mencionar que não é a mera reiteração por si apta a provocar a perda, entretanto, é aquela repetição que traz efetivos prejuízos aos menores e cujo saneamento menos traumático depende do decreto da perda do poder familiar.

O abandono referido pode ser caracterizado nas hipóteses em que a conduta do genitor exponha o filho a situações de vulnerabilidade física, psíquica, moral e intelectual. Diz respeito à omissão do pai quanto à preservação da saúde, educação e bem-estar do menor, com a provocação de concretos danos ao processo de pleno desenvolvimento biológico e de sua personalidade. Relaciona-se também à falta de cuidado e afeto do pai em relação à prole $\mathrm{e}^{339}$.

Em relação à omissão do pai, não necessariamente coincidirá com os tipos penais do abandono de incapaz e do abandono material, previstos nos artigos 133 e 244, do Código Penal. A sua caracterização pode ocorrer com a configuração de prejuízos menos extensos do que os previstos na legislação criminal, bem como independer, inicialmente, da existência de dolo ou culpa por parte dos pais ${ }^{340}$.

Outra referência é a prática de atos contrários à moral e aos bons costumes, os quais dizem respeito àquelas situações em que a conduta do pai atenta frontalmente àquilo normalmente esperado no desenrolar das relações deste com os filhos. Tais ações tomam como base procedimentos voltados não ao preenchimento das condições necessárias à

\footnotetext{
339 Idem.

340 Idem. p. 289.
} 
garantia do melhor interesse dos menores, e sim à sua exposição a situações degradantes do ponto de vista social, psicológico e moral, ou mesmo direcionadas à satisfação de anseio pessoais dos genitores que fogem ao cumprimento dos deveres do poder familiar. Atua-se de maneira claramente desregrada, ignominiosa, infamante, indecente.

Tudo o quanto dito em relação à suspensão do poder familiar, como a prescindibilidade de culpa ou dolo do genitor a ser destituído, a necessidade de processo contraditório e os legitimados a requerê-la, aplica-se à perda do poder familiar.

Apenas deve ser acrescentado que a cautela para a imposição dessa medida necessita ser ainda maior do que aquela já referida quando da análise da atitude legal menos gravosa. Exatamente por corresponder a uma destituição definitiva e irrevogável $^{341}$ da função em comento, sua imposição não se resume a uma mera subsunção dos fatos às situações abstratamente consideradas pela lei como legitimantes. Na realidade, o questionamento sobre o cabimento da perda do poder familiar leva em conta, como convém destacar, não o seu caráter punitivo, mas a proporção de sua necessidade como fator de preservação dos direitos das crianças e dos adolescentes em situação de prejuízo.

Quanto à tutela, excetuados os casos de incapacidade para o exercício, ou em que o "múnus" é escusável, conforme as hipóteses previstas pelo Código Civil ${ }^{342}$, ou seja, o

341 “Como se vê, no direito estrangeiro há um compromisso manifesto e claro com o princípio da proteção integral do menor. Via de regra, a privação da autoridade paterna pode ser superada, cessados os motivos que a ensejaram, e quaisquer que sejam eles, havendo interesse do filho que assim recomende, o que não se observa no Código Civil. Mas, de qualquer forma, serve a análise para fundamentar o entendimento, esposado há pouco, de que a nova norma do direito brasileiro que coloca perda do poder familiar como causa de sua extinção não se afigura a que melhor atende aos interesses do menor.”. Ibidem. p. 297-298.

342 Art. 1.735. Não podem ser tutores e serão exonerados da tutela, caso a exerçam:

I - aqueles que não tiverem a livre administração de seus bens;

II - aqueles que, no momento de lhes ser deferida a tutela, se acharem constituídos em obrigação para com o menor, ou tiverem que fazer valer direitos contra este, e aqueles cujos pais, filhos ou cônjuges tiverem demanda contra o menor;

III - os inimigos do menor, ou de seus pais, ou que tiverem sido por estes expressamente excluídos da tutela;

IV - os condenados por crime de furto, roubo, estelionato, falsidade, contra a família ou os costumes, tenham ou não cumprido pena;

$\mathrm{V}$ - as pessoas de mau procedimento, ou falhas em probidade, e as culpadas de abuso em tutorias anteriores;

VI - aqueles que exercerem função pública incompatível com a boa administração da tutela.

Art. 1.736. Podem escusar-se da tutela:

I - mulheres casadas;

II - maiores de sessenta anos;

III - aqueles que tiverem sob sua autoridade mais de três filhos;

IV - os impossibilitados por enfermidade;

$\mathrm{V}$ - aqueles que habitarem longe do lugar onde se haja de exercer a tutela;

VI - aqueles que já exercerem tutela ou curatela; 
impedimento é prévio a sua constituição, será destituído o tutor quando negligente ou prevaricador, conforme artigo 1.766, da mesma lei. A análise da conduta do tutor deve se dar sob a ótica do atendimento prioritário do melhor interesse das crianças e dos adolescentes tutelados, nos termos do quanto aduzido no tocante ao exercício do poder familiar.

Portanto, a destituição do tutor também dependerá de decisão judicial em que seja observado amplo contraditório e seja norteado por essa preocupação acerca da proteção integral dos direitos do menor.

É evidente que nessa relação de tutela existe uma diferença fundamental que deva ser tomada em consideração, consubstanciada, precisamente, na maior facilidade de substituição da figura do tutor por outro igualmente idôneo. Esta mesma possibilidade não é cabível de ser efetuada de maneira simples no caso da perda do poder familiar por um ou ambos os pais.

A diversidade do presumido afeto nas relações entre pais e filhos, e tutores e menores tutelados, impõe uma análise diferenciada, que, contudo, pode se demonstrar inoportuna no caso concreto. Em situações excepcionais, o amor e cuidado que unem tutor e tutelado podem ser mais intensos do que aqueles verificados entre a prole e o genitor.

De todo modo, por qualquer ângulo que se enxergue a questão, vale o quanto dito e sublinhado até o presente momento: o norte deve ser, sempre, a preservação mais eficaz dos interesses infanto-juvenis. Não somente por uma imposição normativa estabelecida por todo arcabouço jurídico brasileiro, mas puramente em consideração a uma atitude ética que determine o trato da criança e do adolescente como pessoas em formação, com características próprias que devem ser respeitadas.

O futuro dos menores, se bem trabalhado o presente, significa a construção de uma convivência social voltada ao estabelecimento de padrões que concretizem um efetivo respeito à condição humana, baseada na autonomia e no bem-estar que permitam o desenvolvimento das potencialidades próprias de cada um.

É imprescindível destacar que as medidas comentadas poderão ser tranquilamente aplicadas ao âmbito das pesquisas clínicas quando a participação das crianças e

VII - militares em serviço.

Art. 1.737. Quem não for parente do menor não poderá ser obrigado a aceitar a tutela, se houver no lugar parente idôneo, consangüíneo ou afim, em condições de exercê-la. 
adolescentes for prejudicial a seus direitos, especialmente aos da personalidade, e poder a conduta dos pais e tutores ser enquadrada naquelas hipóteses referidas que justificam tal incidência. Toda análise sobre a plausibilidade dessas medidas dependerá da avaliação dos contornos do caso concreto.

Portanto, a suspensão e destituição do poder familiar, bem como a exoneração da tutela são instrumentos legais colocados à disposição da salvaguarda do melhor interesse das crianças e adolescentes, sem intenção de se tornarem meios próprios de sanção punitiva aos pais e tutores faltosos, devendo a atuação no caso concreto ser precedida de uma reflexão calcada no cuidado e na precaução.

\section{CONCLUSÃO}

A atitude ética de cuidado deve pautar toda a conduta humana, mas de maneira primordial, por força do quanto disposto na Constituição, aquelas atividades que se relacionem, de alguma forma, às crianças e adolescentes, concretizando, desta forma, a proteção integral do melhor interesse da criança.

Observe-se que esta prevalência dos interesses dos menores tem como pressuposto básico a corresponsabilidade entre Estado, sociedade e família na implementação e efetivação dos mecanismos aptos a oferecer o atendimento do melhor interesse da criança e do adolescente.

Há um dever implícito, mais realçado do que em outras áreas, de que a conduta dos membros destes três entes seja antecipatória, que busque evitar violações, através das medidas pertinentes, antes de sua ocorrência, sem exclusão da possibilidade de adoção de meio reparadores, já que os danos produzido aos menores, devido a sua peculiar situação de indivíduo em formação biopsíquica, são potencializados e de difícil correção quando comparados com os prejuízos do mesmo tipo impingidos a seres adultos.

Além disso, a posição de dependência dos menores em relação aos seus pais ou responsáveis legais, por conta de sua ainda não completamente desenvolvida autonomia, impõe a avaliação cuidadosa de atividades que porventura possam colocar em risco a sua integridade física e psíquica, ainda que sob a justificativa de produção de um bem mediato. Soma-se a isso a própria relação de afeto existente entre pais e filhos que pode turvar a visão dos primeiros no que tange ao atendimento dos interesses destes últimos em uma 
perspectiva global.

Desta forma, mostra-se como extremamente relevante que o Estado-legislador normatize as questões referentes a essa relação em situações-limite como aquelas atinentes à pesquisa clínica, sendo imperiosa, também, a participação do Ministério Público como intermediador em tais hipóteses. Aliás, a intervenção pelo "parquet" consubstancia mandamento da Constituição Federal e do Estatuto da Criança e do Adolescente, devendo os membros dele adotar uma postura ativa de controle preventivo, acima de tudo, sem olvidar, contudo, a adoção de medidas que visem à reparação dos prejuízos eventualmente nascidos.

Por fim, cabe ao Estado-juiz, caso se depare com conflitos entre alegados interesses dos menores, pautar sua atuação de acordo com o critério do cuidado, da precaução, tomando suas decisões no sentido da proteção integral da saúde física e psíquica da criança, evitando situações em que os riscos superem os possíveis benefícios que poderiam advir da realização de uma determinada atividade, sempre considerando também a vulnerabilidade dos menores, autonomia reduzida e a sua peculiar relação afetuosa com seus pais.

Não se deve adotar, entretanto, uma postura preconceituosa em relação aos pais ou responsáveis legais, que na maioria das vezes, ainda que após a análise do caso concreto revele-se estarem agido erroneamente, pautam sua conduta com base na preservação da integridade da prole.

Essa atitude especial frente aos interesses existenciais dos menores, como são a saúde e a autonomia, reforça a posição privilegiada de que gozam os chamados direitos humanos ou fundamentais, no contexto das ordens jurídicas internacional e interna, fruto de um longo processo de reconhecimento e sistematização.

Estes direitos encontram o seu respaldo na condição humana, cuja qualidade abstrata principal, alicerce e objetivo do Direito, consiste na potencialidade da autoconsciência de si próprio dentro do processo histórico, ou seja, na autonomia, o que redunda no estabelecimento de garantias individuais e concretas. É a ética da igualdade e da liberdade, conformadas pelo Direito na proporção em que possibilitem a convivência pacífica e saudável das pessoas, que dá suporte aos citados direitos.

Claro que a existência de inúmeros direitos fundamentais, titularizados por todas pessoas, acarreta o risco de colisões entre esses na sua concreção, servindo como padrão 
referencial para a solução destes choques exatamente o supraprincípio da dignidade da pessoa humana.

O conceito de dignidade humana não pode ser manejado de acordo com um conteúdo deveras vago, instrumentalizado de maneira desmedida, sem critérios, mas deve determinar a tomada de um caminho que mais preserve a manutenção da vida saudável e da autonomia da pessoa individualmente considerada.

Essas considerações são de suma importância no âmbito bioético, tendo em vista que neste se lida, em sua formulação mais atual e difundida, com problemas atinentes ao ser humano, à sua existência, à sua saúde, considerando-se aquela sua condição peculiar no mundo natural.

Trata-se a bioética de área multidisciplinar, em que profissionais da saúde, cientistas e juristas, sobretudo, devem buscar a formulação de esquemas e paradigmas que possibilitem o bom termo da contínua tensão existente entre o avanço científico, que pode produzir resultados que permitam a preservação da saúde, de um lado, e o prestígio à autonomia individual, de outro. $\mathrm{E}$ isto se torna mais claro no que tange às pesquisas médicas, tendo em vista que são procedimentos centrados no risco ao sujeito voluntário, realizados com a finalidade de aferição da segurança e eficácia terapêutica de determinados tratamentos médicos, demandando a atenção especial do Direito, responsável, em última análise, pela escolha das decisões sociais axiológicas mais básicas e importantes.

Diante de tal constatação é que se pode afirmar a insuficiência do acompanhamento das pesquisas clínicas por órgãos não estatais, sem maiores garantias constitucionais de independência, os denominados Comitês de Ética em Pesquisa, e, mais uma vez, a inexorabilidade da intervenção do Ministério Público nestas atividades. Importante ressalvar: a conduta do "parquet" deve-se revestir de excepcional cautela, pois muitas vezes uma eventual interrupção de um teste com crianças e adolescentes, que sempre deverá possuir finalidades terapêuticas, pode acarretar sérios prejuízos à saúde destes.

Além disso, neste campo dos testes científicos com seres humanos, ganha grande importância a obtenção do consentimento informado prévio à realização da atividade potencialmente danosa, devendo este não ser encarado apenas como uma etapa burocrática, mas como efetivo instrumento de preservação da autonomia do indivíduo, com a prestação de dados claros, completos e adequados às suas condições pessoais, para que a decisão 
sobre sua participação no experimento seja tomada de forma realmente livre. E esta necessidade está presente mesmo nos casos em que, legalmente, alguém não tenha plena capacidade de decisão, como no dos menores de idade, exatamente por envolver interesses existenciais destas pessoas, patamar mínimo de incidência dos direitos fundamentais e da personalidade.

A vontade das crianças e adolescentes é levada em consideração desde que não represente perigo maior à sua própria existência saudável, sem desconsideração, contudo, da opinião dos próprios responsáveis pelo menor, presumivelmente mais bem preparados e interessados na proteção do melhor interesse daqueles. Eventual conflito entre essas partes deverá ser solucionado pelo Juiz, daí, mais uma vez, a necessidade de intervenção do Ministério Público na atividade de pesquisas clínicas que envolvam as crianças e os adolescentes.

Ademais, por trazerem em seu bojo os riscos à incolumidade física dos seres humanos, as experimentações clínicas estão sujeitas à incidência do denominado princípio da precaução, que determina um estudo prévio, bem informado e discutido, como etapa necessária à decisão, em última análise, sobre a conveniência ou não daquela atividade, considerando os possíveis benefícios que ela possa acarretar. A especialidade desta atividade de risco impõe, dentre outros fatores, como se viu, a necessidade de que sua regulamentação ocorra mediante lei formal, emanada do Poder Legislativo.

Cumpre recordar que com crianças e adolescentes, as pesquisas clínicas somente podem ser realizadas se tiverem objetivo terapêutico e na proporção em que os possíveis benefícios superem os riscos potenciais.

Além disso, exige-se, a partir de tal princípio da precaução, e desde que seja positivo o juízo acima referido, a tomada de medidas que evitem, ao máximo, a transmudação daqueles riscos em prejuízos concretos, ou que possibilitem a ampla e pronta reparação ou indenização destes quando porventura venham a acontecer, tornando imperativa, mais uma vez, a participação do Ministério Público.

Quanto à responsabilidade civil, o esquema tradicional de se analisar as obrigações médicas como de meio, ou seja, que se consideram cumpridas desde que a própria atividade do profissional seja executada de maneira diligente e correta, independentemente do alcance ou não do resultado almejado, mostra-se efetivo apenas naqueles tratamentos com fins exclusivamente terapêuticos. Não se aplica este 
entendimento àquelas atividades cujo resultado é a essência de sua própria existência e viabilidade, como ocorre com as pesquisas clínicas, cuja finalidade, em certa medida, é a aferição da segurança e eficácia de um determinado tratamento. Nesses casos, tais obrigações assumirão o papel de verdadeiras obrigações de resultado.

Todavia, ordinariamente, há nas obrigações de resultado e quando este não tenha sido atingido, uma efetiva presunção relativa de culpa do profissional, mas que pode ser afastada, não possuindo tal questão, pois, qualquer relação com a responsabilidade objetiva.

No caso dos experimentos clínicos, existe um fator agregado originário da peculiar natureza de atividade claramente de risco, assumido por pesquisadores, patrocinadores, promotores e instituições de pesquisa, mediante negócio jurídico com os sujeitos de pesquisa, qual seja a responsabilização objetiva daqueles agentes, com base no artigo 927, do Código Civil, e na Resolução 196/96, que por si só, entretanto, não seria capaz de estabelecer este modo de responsabilização extraordinário, não fosse o quanto previsto no dispositivo legal.

De qualquer modo, é necessária a aferição do dano, decorrente da participação do sujeito no experimento, e do nexo causal entre esta e o prejuízo causado à vítima, sem indagação sobre a culpabilidade do agente.

Nem sempre será possível identificar um vínculo claro entre o dano produzido e a participação da vítima na pesquisa clínica, como, por exemplo, nos casos em que esta ação elimina uma possibilidade real de cura, ou mesmo agrava proporcionalmente os riscos de produção de certo resultado.

No primeiro caso, surge a chamada teoria da perda de uma chance de cura, que gera a responsabilização do agente, na razão em que sua conduta tenha eliminado uma chance real de obtenção de um resultado final positivo. Note-se que a avaliação da perda desta chance será feita mediante um sistema de probabilidades de que aquela determinada conduta pudesse solidamente acarretar a eliminação de uma ou mais chances sérias de obtenção deste resultado útil.

Tal teoria, ainda que com fins louváveis, torna-se de aplicação prática insuficiente, pois concerne tão somente aos casos em que haja perda das chances de cura e não àqueles em que outros danos possam ser produzidos.

Nesse contexto, com a finalidade de afastar tais problemas quanto à teoria da 
perda de uma chance, ainda que não se pretenda, inicialmente, inutilizar esta, surge a teoria do incremento dos riscos, corrigida criticamente no presente trabalho no sentido do estabelecimento da presunção do nexo causal, aplicável em determinados casos e com o objetivo, também, de tutelar aquelas situações não cobertas pelo modelo esquemático clássico de responsabilização.

De acordo com tal teoria, nos casos em que haja um prejuízo ao paciente, mas que não pode ser claramente imputado à participação da vítima na pesquisa clínica, dever-se-á analisar em que medida este fato incrementou os riscos de produção deste prejuízo.

Observe-se que nesses casos, há, desde o início, a possibilidade de produção de certos resultados indesejados. Contudo, verificado posteriormente o nascimento de tais prejuízos, é mister que se proceda a uma séria análise, baseada em métodos de probabilidade, de como a participação do sujeito na pesquisa aumentou o seu grau de exposição aos riscos de produção deste prejuízo. Se há uma não desprezível possibilidade de que aqueles danos estejam ligados aos experimentos clínicos, nascerá o dever de indenizar. De qualquer forma, caberá aos pesquisadores/patrocinadores provar a inexistência desta correlação, quando existam elementos mínimos que permitam a sua presunção.

Já o dever de indenizar dos responsáveis legais do menor que sofreu danos no âmbito das pesquisas clínicas enquadra-se no esquema subjetivo ordinário, com apreciação de culpa, porque além de não estar previsto em exceções legais, não se pode caracterizar a sua atividade, de cuidado e proteção da criança e adolescente, como típica atividade de risco, que aliás, em regra, nenhum proveito trará àqueles.

Além disso, cabível, também, a suspensão ou perda do familiar, ou remoção da tutela, sempre levando em consideração o interesse do menor, em detrimento do aspecto punitivo destas medidas, naqueles casos em que a participação da criança ou do adolescente no experimento clínico mostre-se prejudicial e a manutenção dos poderesdeveres dos responsáveis legais revele-se danosa aos direitos do menor. Neste caso, a avaliação da culpa dos responsáveis legais é despicienda.

De toda sorte, em qualquer caso de responsabilização pelos danos causados em pesquisas clínicas, mormente quando os prejuízos sejam de ordem moral, deve-se, de acordo com o princípio de proteção integral do melhor interesse da criança e do adolescente, prevalecer a tutela específica, buscando restabelecer ao máximo a 
incolumidade física e psíquica do menor, bem como o processo de desenvolvimento saudável.

Portanto, essencial para a realização das pesquisas clínicas com crianças e adolescentes que estas primem pelo atendimento do melhor interesse deles, respeitando a sua qualidade de pessoa em desenvolvimento, bem como os seus direitos fundamentais, especialmente a autonomia, sendo imprescindível, pela própria natureza da atividade analisada e de acordo com os mandamentos constitucionais e legais, a participação do Ministério Público. 


\section{BIBLIOGRAFIA}

Associação Médica Brasileira. Jornal da Sociedade Brasileira de Cardiologia, $\mathrm{n}^{\circ} 88$, jul./ago. 2008, p.11., disponível em http://jornal.cardiol.br/2008/jul-ago/outras/amb.pdf. Acessado em 20.10.2009.

ALONSO, Paulo Sérgio Gomes. Pressupostos da responsabilidade objetiva. São Paulo: Saraiva, 2000

ANDRADE, Romero de Oliveira. In: CURY, Munir (coord.). Estatuto da Criança e do Adolescente Comentado. Comentários jurídicos e sociais. $11^{\mathrm{a}}$ ed. São Paulo: Malheiros Editores, 2010. pp. 119-120.

ARISTÓTELES. A Política. Trad. Roberto Leal Ferreira. São Paulo: Martins Fontes, 2006.

ÁVILA, Humberto Bergman. Teoria dos princípios: da definição à aplicação dos princípios. $5^{\text {a }}$ ed. ampl. e atual. São Paulo: Malheiros, 2006.

AZEVEDO, Antônio Junqueira de. "Crítica ao personalismo ético da Constituição da República e do Código Civil”. In: AZEVEDO, Antônio Junqueira de; TÔRRES, Heleno Taveira; CARBONE, Paolo; (coords.). Princípios do novo Código Civil Brasileiro e Outros Temas. Homenagem a Tullio Ascarelli. $2^{\mathrm{a}}$ ed. São Paulo: Quartier Latin, 2010. pp. 20-31.

BARBOZA. Heloisa Helena. "Responsabilidade civil em face das pesquisas em seres humanos: efeitos do consentimento livre e esclarecido". In: MARTINS-COSTA, Judith; MÖLLER, Letícia Ludwig. Bioética e responsabilidade. Rio de Janeiro: Forense 2009. pp. 205-234.

"Poder familiar em face das práticas médicas". In: Revista do Advogado. Ano XXIV, no 76, junho de 2004. São Paulo: AASP, 2004. pp. 40-46. 
BARNI, Mauro. Diritti - Doveri. Responsabilità del medico dalla bioetica al biodiritto. Milano: Giuffrè, 1999.

"Responsabilità del medico". In: Il rischio in medicina oggi e la responsabilità professionale. Atti del Convegno di Studio della Federazione Nazionale degli ordini dei Medici Chirurghi e degli Odontoiatri. Milano: Giuffrè Editore, 1999. pp. 115-126.

BARNI, Mauro; DELL'OSSO, Giuseppe . "I diritti del soggeto nella sperimentazione e nella pratica medica: aspetti medico-legali”. In DELL'OSSO, Giuseppe (coord.). Responsabilità e progresso medico. Milano: Giuffrè Editore, 1984.

BARROS, Sérgio Resende de. "Direitos humanos da família: dos fundamentais aos operacionais. In: PEREIRA, Rodrigo da Cunha (coord). Afeto, Ética, Família e o novo Código Civil. Belo Horizonte: Del Rey, 2004. pp. 606-620.

BARZOTTO, Luiz Fernando. "Pessoa e reconhecimento - uma análise estrutural da dignidade da pessoa humana". In: ALMEIDA FILHO, Agassiz; MELGARÉ, Plínio (orgs.). Dignidade da pessoa humana. Fundamentos e critérios interpretativos. São Paulo: Malheiros Editores, 2010, pp. 39-67.

BECK, Ulrich. Risk Society. Towards a New Modernity. Trad. para o inglês Mark Ritter. $1^{\mathrm{a}}$ ed em inglês. $7^{\mathrm{a}}$ reimpr. London: SAGE Publications, 2007.

BERG, Jessica W.; APPELBAUM, Paul S.; LIDZ, Charles W.; PARKER, Lisa S. Informed consent. Legal theory and clinical practice. $2^{\mathrm{a}}$ ed. New York: Oxford University Press, 2001.

BITTAR, Eduardo C. B. Curso de ética jurídica: ética geral e profissional. $4^{\mathrm{a}}$ ed. rev. São Paulo: Saraiva, 2007.

BOBBIO, Norberto. A era dos direitos. Trad. Carlos Nelson Coutinho. Rio de Janeiro: 
Campus, 1992.

BOITEUX, Elza Antônia Pereira Cunha; BOITEUX, Fernando Netto. Poluição eletromagnética e meio ambiente: o princípio da precaução. Porto Alegre: Sergio Antonio Fabris Ed., 2008.

CASABONA, Carlos María Romeo. "La investigación con células troncales, técnicas de clonación y otras de reprogramación celular: el debate jurídico y jurídico-penal actual”. In: Revista brasileira de ciências criminais. $n^{\circ}$ 77. São Paulo: RBCCRIM, 2009. pp. 7-39.

CASSETARI, Christiano. "Responsabilidade civil dos pais por abandono afetivo de seus filhos - dos deveres constitucionais". In: Revista IOB de Direito de Família, v. 9, no 50, out./nov. 2008. Porto Alegre, 2008. pp. 87-99.

CAVALIERI FILHO, Sérgio. “A responsabilidade médico-hospitalar à luz do Código do Consumidor". pp. 131-141. In: Revista Forense. v. 346, ano 95. Rio de Janeiro. abr./mai./jun 1999.

Programa de responsabilidade civil. 9a ed., São Paulo: Atlas, 2010.

CHAVES, Antônio. "Pesquisa em seres humanos". In: Revista de Informação Legislativa, v. 27, no 108, out./dez. 1990. Brasília, 1990. pp. 229-252.

COMEL, Denise Damo. Do poder familiar. São Paulo: Editora Revista dos Tribunais, 2003.

COMPARATO, Fábio Konder. Ética: direito, moral e religião no mundo moderno. $3^{\mathrm{a}}$ reimpr. São Paulo: Companhia das Letras, 2006.

A afirmação histórica dos direitos humanos. $2^{\mathrm{a}}$ ed., São

Paulo: Saraiva, 2001. 
CORBETT, Angus. "A reformulation of the right to recover compensation for medically related injuries in the tort of negligence". pp. 141-178. The Sydney Law Review. v. 19, $\mathrm{n}^{\circ}$ 2. Sydney, june 1997.

COSTA, Maria Isabel Pereira da. "A responsabilidade civil dos pais pela omissão do afeto na formação da personalidade dos filhos". In: Revista Jurídica, ano 56, $\mathrm{n}^{\mathrm{o}} 368$, junho de 2008. Porto Alegre, 2008.

"Família: do autoritarismo ao afeto. Como e a quem indenizar a omissão do afeto? In: Revista Brasileira de Direito de Família. Ano VII, $n^{\circ} 32$, out./nov. 2005. Porto Alegre: IOB Thomson. pp. 20-39.

DIAS, José Aguiar. Da responsabilidade civil. $11^{\mathrm{a}}$ ed. revista, atual. de acordo com o Código Civil 2002, e aum. por Rui Berford Dias. Rio de Janeiro: Renovar, 2006.

DINIZ, Maria Helena. O estado atual do biodireito. $2^{\mathrm{a}}$ ed. aum. e atual. de acordo com o novo Código Civil (Lei nº 10.406 de 10.01.2002). São Paulo: Saraiva, 2002.

DONNELY, Jack. Universal human rights in theory and practice. $2^{\mathrm{a}}$ ed. Ithaca: Cornell University Press, 2003.

ELIAS, Roberto João. Comentários ao Estatuto da Criança e do Adolescente: Lei n. 8.069, de 13 de julho de 1990. 4ª ed. São Paulo: Saraiva, 2010.

ELIAS, Telma de Melo. Direito à vida e à saúde no Estatuto da Criança e do Adolescente. Dissertação(Mestrado pela Faculdade de Direito do Largo São Francisco da Universidade de São Paulo. São Paulo, 2005. 142p. p. 14.

ESTADOS UNIDOS DA AMÉRICA. Belmont Report (Relatório Belmont). Disponível em

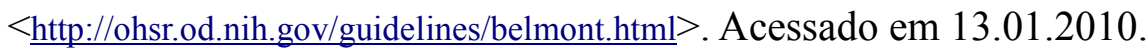

European Medicines Agency (EMEA). Guideline for Good Clinical Practice. 1997, . 
Disponível

$<$ http://www.ema.europa.eu/docs/en_GB/document_library/Scientific_guideline/2009/09/WC5000028 74.pdf>. Acessado em 22.01.2011.

EUSEBÍ, Luciano. "Controllo etico e tutela penale nella sperimentazione in ambito sanitario". In: Rassegna Italiana di criminologia. Indici 1993, Milano: Giuffrè Editore, 1993.

FACHIN, Luiz Edson. "Do pater familias à autoridade parental. Elementos da travessia entre 'pátrio poder', 'poder familiar' e 'autoridade parental'". In: Revista do Advogado. Ano XXXI, nº 112, julho de 2011. São Paulo: AASP, 2011. pp. 99-103.

FEDERIGHI, Wanderley José. A responsabilidade civil dos pais. Dissertação(Mestrado pela Faculdade de Direito do Largo São Francisco da Universidade de São Paulo). São Paulo, 1997. 191p.

FERNANDES, Elizabeth Alves. Bioética e direitos humanos: a proteção da dignidade da pessoa humana na era da genética. Dissertação(Mestrado pela Faculdade de Direito do Largo São Francisco da Universidade de São Paulo). São Paulo, 2008. 163 p.

FERRANDO, Gilda. "L`sperimentazione sull'uomo". In: BARNI, Mauro; SANTOSUOSSO, Amedeo. Medicina e Diritto. Milano: Giuffrè, 1995. pp. 231-257.

FERREIRA, Lucia Maria Teixeira; BITTENCOURT, Sávio Renato. “As políticas públicas e o Ministério Público como agentes garantidores do direito à convivência familiar e comunitária de crianças e adolescentes abrigados”. In: Revista do Advogado. Ano XXVIII, $\mathrm{n}^{0}$ 101, dezembro de 2008. São Paulo: AASP, 2008. pp. 62-69.

FRANÇA, Genival Veloso de. Direito médico. $9^{\mathrm{a}}$ ed. rev. Atual. e ampl. Rio de Janeiro: Forense, 2007.

FREITAS, Corina Bontempo D.; HOSSNE, William Saad. "Pesquisa com Seres 
Humanos”. In: COSTA, Sérgio Ibiapina Ferreira; GARRAFA, Volnei; OSELKA, Gabriel. Iniciação à bioética. Brasília: Conselho Federal de Medicina, 1998. pp. 193204.

FREITAS, Juarez. "Princípio da precaução: vedação de excesso e de inoperância". In: Interesse Público. Ano VII, no 35, Porto Alegre: Notadez Informação, 2006. pp. 3348.

GALINDO, Gilberto Cely. "Principios bioéticos e investigación en clínica humana". In: El horizonte bioético de las ciências. Santafé de Bogotá: Centro Editorial Javeriano, 1995. p. 312.

GAMA, Guilherme Calmon Nogueira da. A parentalidade responsável e o cuidado: novas perspectivas. In: Revista do Advogado, Ano XXVIII, no 101, São Paulo: AASP, dezembro de 2008. pp. 29-36.

GARCIA, Basileu. Instituições de Direito Penal, v. I, tomo I. $7^{\mathrm{a}}$ ed. rev. e atual. São Paulo: Saraiva, 2008. p. 296.

GARCIA, Enéas Costa. Direito geral da personalidade no sistema jurídico brasileiro. São Paulo: Editora Juarez de Oliveira, 2007.

GARRAFA, Volnei. "Bioética e Ciência - Até onde Avançar sem Agredir". In: COSTA, Sérgio Ibiapina Ferreira; GARRAFA, Volnei; OSELKA, Gabriel. Iniciação à bioética. Brasília: Conselho Federal de Medicina, 1998. pp.99-109.

GRANDE, Lydia Feito. “Por qué Bioética?” In: GRANDE, Lydia Feito (ed.). Estudios de Bioética. Madrid: Dykynson, 1997. pp. 3-18.

GODOY, Claudio Luiz Bueno de. Responsabilidade civil pelo risco da atividade: uma cláusula geral no Código Civil de 2002. São Paulo: Saraiva, 2009. 
GOGLIANO, Daisy. “Autonomia, bioética e direitos da personalidade". In: Revista de Direito Sanitário. Vol. 1, n 1, novembro de 2000. São Paulo: LTr, 2000. pp. 107-127.

GOLDIM, José Roberto. "Bioética complexa: uma abordagem abrangente para o processo de tomada de decisão”. In: Revista da AMRIGS, 53 (1): jan.-mar. 2009, Porto Alegre, 2009. pp. 58-63. p. 59. Disponível em <www.bioetica.ufrgs.br $>$. Acessado em 23.08.2010.

"Bioética: Origens e Complexidade". In: Revista HCPA, 26(2). Porto Alegre, 2006 pp. 86-92. p. 87. Disponível em <www.bioetica.ufrgs.br $>$ Acessado em 20.08.2010.

GONÇALVES, Carlos Roberto. Responsabilidade civil. 11 a ed. rev. São Paulo: Saraiva, 2009. p. 24.

GONÇALVES, Vitor Fernandes. "Da proteção da pessoa dos filhos no Brasil e na Inglaterra". In: Revista da Fundação Escola Superior do Ministério Publico do Distrito Federal e Territórios. v.2, n.94, jul./dez. 1994. Brasília, 1994.. pp. 199-216.

GONDIM, Glenda Goçalves. "Responsabilidade Civil: teoria da perda de uma chance”. pp. 11-33. In: Revista dos Tribunais. v. 840, ano 94, outubro de 2005.

GRACIA, Diego. "Cuestión de Principios". In GRANDE, Lydia Feito (ed.). Estudios de Bioética. Madrid: Dykynson, 1997. pp. 19-42.

GUIMARÃES, José Alfredo Cruz. "Responsabilidade médico-hospitalar em face do Direito do Consumidor.” In: Revista de Direito Privado, n 10, ano 3, abr./jun. 2002. Ed. Revista Dos Tribunais. São Paulo. pp. 128-140.

HAMMERSCHMIDT, Denise. "O risco na sociedade contemporânea e o princípio da precaução no direito ambiental". In: Revista dos Tribunais, nº 808, fev. 2003. São Paulo: Revista dos Tribunais, 2003. pp. 39-56. 
HEGEL, Georg Wilhem Friedrich. Fenomenologia do Espírito. Trad. de Paulo Meneses, com a colab. de Karl Heinz Efken e José Nogueira Machado. 4ª ed. Petrópolis, RJ: Vozes: Bragança Paulista: Editora Universitária São Francisco, 2007.

HERMITTE, Marie-Angelè; DAVID, Virginie. "Avaliação dos riscos e princípio da precaução”. In: VARELLA, Marcelo Dias; PLATIAU, Ana Flávia Barros (coords.). Princípio da precaução. Belo Horizonte: Del Rey, 2004. pp. 93-155.

HIRONAKA, Giselda Maria Fernandes Novaes. "Bioética e biodireito: revolução biotecnológica, perplexidade humana e prospectiva jurídica inquietante". In: CANEZIN, Claudete Carvalho (coord.). Arte Jurídica - Biblioteca Científica de Direito Civil e Processo Civil. v. 3, nº 1. Curitiba: Juruá, 2006. pp. 23-37.

"Responsabilidade civil na relação paterno-filial”. In: Novos Estudos Jurídicos, v.7. n.14, abril de 2002. Itajaí, 2002. pp. 69-101

HOBBES, Thomas. Leviatã, ou, Matéria, forma e poder de um estado eclesiástico e civil. Org. Richard Tuck; ed. bras. superv. por Eunice Ostrenky; trad. por João Paulo Monteiro e Maria Beatriz Nizza da Silva; trad. do aparelho crítico por Cláudia Berliner; rev. da trad. Eunice Ostrenky. 2a ed, São Paulo: Martins Fontes, 2008.

HOSSNE, William Saad; VIEIRA, Sonia. "Experimentação com seres humanos: aspectos éticos”. In: SEGRE, Marco; COHEN, Cláudio. Bioética. $2^{\mathrm{a}}$ ed. ampl. São Paulo: EDUSP, 1999. pp. 126-146.

JONAS, Hans. Técnica, medicina y ética. Sobre la práctica del principio de responsabilidad. Trad. para o espanhol Carlos Fortea Gil. $1^{\text {a }}$ ed. em espanhol. Barcelona: Paidós, 1997.

JONSEN, Albert R. "Bioética: Alguns aspectos de sua gênese e de seu desenvolvimento - 
O nascimento da bioética". In: PESSINI, Leocir; DE BARCHIFONTAINE, Christian de Paul. Problemas atuais de bioética. $8^{\mathrm{a}}$ ed. rev. e ampl. São Paulo: Ediçoes Loyola, 2008. p. 47.

KANT, Immanuel. Fundamentação da metafísica dos costumes. Trad. António Pinto de Carvalho. São Paulo: Companhia Editora Nacional.

KELSEN, Hans. Teoria pura do Direito. Trad. João Baptista Machado. $8^{\mathrm{a}}$ ed., $2^{\mathrm{a}}$ tir. São Paulo: WMF Martins Fontes, 2011.

KFOURI NETO, Miguel. Responsabilidade Civil do Médico. $7^{\mathrm{a}}$ ed. rev. atual. e ampl. São Paulo: Editora Revista dos Tribunais, 2010.

Culpa médica e ônus da prova. Presunções, perda de uma chance, cargas probatórias dinâmicas, inversão do ônus probatório e consentimento informado. Responsabilidade civil em pediatria, responsabilidade civil em ginecoobstetrícia. São Paulo: Editora Revista dos Tribunais, 2002.

KIPPER, Délio José; CLOTET, Joaquim. "Princípios da beneficência e não-maleficência". In: COSTA, Sérgio Ibiapina Ferreira; GARRAFA, Volnei; OSELKA, Gabriel. Iniciação à bioética. Brasília: Conselho Federal de Medicina, 1998.

KRAUT, Alfredo Jorge. Los derechos de los pacientes. Buenos Aires: Abeledo-Perrot, 1997.

LEAL, Rosemiro Pereira. "Processo e eticidade familiar constitucionalizada". In: PEREIRA, Rodrigo da Cunha (coord). Afeto, Ética, Família e o novo Código Civil. Belo Horizonte: Del Rey, 2004. pp. 593-606.

LAMENZA, Francismar. Os direitos fundamentais da criança e do adolescente e a discricionariedade do Estado. Tese(Doutorado pela Faculdade de Direito do Largo São Francisco da Universidade de São Paulo). São Paulo, 2006. 205 p. 
LIMA, Fernando Antônio Negreiros. A intervenção do Ministério Público no Processo civil brasileiro como 'custos legis'. São Paulo: Método, 2007.

LIMA, Taisa Maria Macena de. "Responsabilidade civil dos pais por negligência na educação e formação escolar dos filhos: o dever dos pais de indenizar o filho prejudicado". In PEREIRA, Rodrigo da Cunha (coord). Afeto, Ética, Família e o novo Código Civil. Belo Horizonte: Del Rey, 2004. pp. 621-631.

LOPEZ, Teresa Ancona. Princípio da precaução e evolução da responsabilidade civil. Tese(Concurso de Professor Titular da Faculdade de Direito da Universidade de São Paulo). São Paulo, 2008. 232 p.

O dano estético: responsabilidade civil. $2^{\mathrm{a}} \mathrm{ed}$. Ed. Revista dos Tribunais, São Paulo, 1999.

Nexo causal e produtos potencialmente nocivos. A experiência brasileira do tabaco. São Paulo: Quartier Latin, 2008.

LORENZETTI, Ricardo Luis. Responsabilidad civil de los médicos. Tomo I. Buenos Aires: Rubinzal-Culzoni Editores, 1997.

MACHADO, Diego Carvalho. "Autonomia privada, consentimento e corpo humano: para a construção da própria esfera privada na era tecnológica”. In: Revista Trimestral de Direito Civil - RTDC, ano 10, vol. 37, janeiro a março de 2009, Rio de Janeiro, 2009. pp. 17-52.

MACHADO, Paulo Affonso Leme. "O princípio da precaução e a avaliação de riscos”. In: Revista dos Tribunais. v. 856, fev. 2007. São Paulo: Revista dos Tribunais, 2007. pp. $35-50$.

MACINTYRE, Alasdair. A Short History of Ethics. $2^{\mathrm{a}}$ ed. reimp. Oxon: Routledge, 2005. 
MAQUIAVEL, Nicolau. O Princípe e Escritos Políticos. Série "Os Pensadores". São Paulo: Ed. Nova Cultural, 1991.

MARIOTTI, Paolo; MASARAKI, Gianlorenzo; RIZZI, Renato. I diritti dei malati. Giuffrè Editore: Milano, 1993.

MARTINS-COSTA, Judith. "Capacidade para consentir e esterilização de mulheres tornadas incapazes pelo uso de drogas: notas para uma aproximação entre a técnica jurídica e a reflexão bioética". In: MARTINS-COSTA, Judith; MÖLLER, Letícia Ludwig (orgs). Bioética e responsabilidade. Rio de Janeiro: Forense, 2009. pp. 299344.

MATIELLO, Fabrício Zamprogna. A responsabilidade civil do médico. $3^{\mathrm{a}}$ ed. São Paulo: LTr, 2006.

MATOS, Eneas de Oliveira. Dano moral e dano estético. Renovar. Rio de Janeiro, 2008.

MAZZILI, Hugo Nigro. "O Ministério Público e o Estatuto da criança e do adolescente”. In: Revista de Informação Legislativa. Ano 29, nº 114, abr/jun 1992. Brasília: Senado Federal, 1992. pp. 157-198.

MELE, Vincenza. "Bioetica della diferenza nell'accettazione delle biotecnologie: diversità di paradigmi scientifici e/o di culturale". In: COMPAGNONI, Francesco; D'AGOSTINO, Francesco (edd). Il confronto interculturale: dibattiti bioetici e pratiche giuridiche. Bioetica, diritti umani e multietnicità. Milano: San Paolo, 2003. pp. 318-335.

MELGARÉ, Plínio. "Notas sobre a repersonalização do direito civil". In: ALMEIDA FILHO, Agassiz; MELGARÉ, Plínio (orgs.). Dignidade da pessoa humana. Fundamentos e critérios interpretativos, São Paulo: Malheiros Editores, 2010, pp. 150-163. 
MENEGUIN, Silmara. Avaliação de como os sujeitos da pesquisa entendem sua participação em ensaios clínicos num hospital terciário. Tese(Doutorado na Faculdade de Medicina da Universidade de São Paulo). São Paulo, 2009. 189p.

MERRY, Alan; SMITH, Alexandre McCall. Errors, Medicine and the Law. Cambridge: Cambridge University Press, 2001.

MONACO, Gustavo Ferraz de Campos; CAMPOS, Maria Luiza Ferraz. "O Direito de audição de crianças e jovens em processo de regulação do exercício do poder familiar". In: CANEZIN. Claudete Carvalho (coord.) Arte Jurídica - Biblioteca Científica de Direito Civil e Processo Civil. v. 3, nº1, Curitiba: Juruá, 2006. pp. 93105.

MOTA, Joaquim Antônio César. "A criança na pesquisa biomédica". In: CASABONA, Carlos María Romeo; QUEIROZ, Juliane Fernandez (coords.). Biotecnologia e suas implicações ético-jurídicas. Belo Horizonte: Del Rey, 2005. pp. 46-62.

NINO, Carlos Santiago. Ética y derechos humanos. Un ensayo de fundamentación. $2^{\mathrm{a}}$ ed., $2^{\mathrm{a}}$ reimp. Buenos Aires: Editorial Astrea, 2007.

NISHIOKA, Sérgio de Andrade. Regulação da pesquisa clínica no Brasil: passado, presente e futuro. In: Prática Hospitalar, Ano VIII, nº 48, Nov-Dez/2006. p. 25. Disponível em $\leq$ http://www.anvisa.gov.br/medicamentos/pesquisa/artigos/artigo_ph 48 sergio_nishioka.pdf?script=s ci_arttext $\% \mathrm{C} 0 \% 03 \mathrm{~d}=\mathrm{S} 0104-42302006000100025 \& \operatorname{lng}=\mathrm{en} \& \mathrm{nrm}=\mathrm{iso}>$. Acessado em 20 de janeiro de 2011.

O’NEILL, Onora. "Kanthian ethics". In: SINGER, Peter (ed.). A companion to ethics. MALDEN/OXFORD/CARLTON: Blackwell Publishing. pp. 175-185.

OLIVEIRA, Guilherme. Temas de Direito da Medicina. Coimbra: Coimbra Editora, 1999. 
OLIVEIRA, Mariana Massara Rodrigues. Responsabilidade civil dos médicos. Curitiba: Juruá, 2008.

OLIVEIRA, Simone Born de. Da bioética ao direito: manipulação genética e dignidade humana. $1^{\mathrm{a}}$ ed. (ano 2002), $5^{\mathrm{a}}$ tir. Curitiba: Juruá, 2006.

OTERO, Paulo. "Pessoa Humana e Constituição: contributo para uma concepção personalista do Direito Constitucional". In: CAMPOS, Diogo Leite de; CHINELlATO, Silmara Juny de Abreu (coords). Pessoa Humana e Direito. Coimbra: Almedina, 2009. pp. 349-380.

PARADISO, Massimo. "La responsabilità medica dal torto al contratto". In: Rivista di Diritto Civile. $\mathrm{n}^{\circ}$ 3, Anno XLVII, maggio-giugno 2001. Padova: CEDAM, 2001. pp. 325-352.

PAULA, Carolina Bellini Arantes de. As excludentes de responsabilidade civil objetiva. São Paulo: Atlas, 2007.

PEDRO, Rute Teixeira. A responsabilidade civil do médico. Reflexões sobre a noção da perda de chance e a tutela do doente lesado. Coimbra: Coimbra Editora, 2008. p. 82.

PEREIRA, Caio Mário da Silva. Instituições de Direito Civil. v. 5, Direito de Família, 16a ed., Atualizado por Tânia Silva Pereira. Rio de Janeiro: Forense, 2006.

PEREIRA JÚNIOR, Antônio Jorge. "Fundamentos de fiscalização e orientação do poder familiar". In: Revista da Faculdade de Direito da Universidade de São Paulo. vol. 97, jan-dez 2002. São Paulo, 2002. pp. 139-179.

PERELMAN, Chaïm. Ética e direito. Trad. Maria Ermantina de Almeida Prado Galvão [rev. da trad. Eduardo Brandão]. 2a ed. São Paulo: Martins Fontes, 2005.

PESSINI, Leocir; DE BARCHIFONTAINE, Christian de Paulo. Problemas atuais de 
bioética. $8^{\mathrm{a}}$ ed. rev. e ampl. São Paulo: Edições Loyola, 2008.

PINNA, Alice. "Autodeterminazione e consenso: da regola per i trattamenti sanitari a principio generale”. In: Contratto e impresa. n 3, anno 22. Padova: CEDAM, 2006. pp. 589-610.

PRADO, Camila Affonso. Responsabilidade civil dos pais pelo abandono afetivo dos filhos menores. Dissertação(Mestrado pela Faculdade de Direito do Largo São Francisco da Universidade de São Paulo). 237 p.

REALE, Miguel. Filosofia do Direito. 20ª Ed, 8 tir.. São Paulo: Saraiva, 2002.

RODRIGUES, João Vaz. O consentimento informado para o acto médico no ordenamento jurídico português. Elementos para o estudo da manifestação da vontade. Coimbra: Coimbra Editora, 2001.

ROMANELLO NETO, Jerônimo. Responsabilidade civil dos médicos. $2^{\mathrm{a}}$ ed. São Paulo: Biblioteca 24 X 7, 2009.

ROSA, Alexandre Morais da. "O cuidado como critério do princípio do melhor interesse da criança. A questão da destituição do poder familiar”. In: Revista do Advogado, Ano XXVIII, nº 101, São Paulo: AASP, dez. 2008. pp. 7-13.

ROSÁRIO, Grácia Cristina Moreira do. A perda da chance de cura na responsabilidade médica. pp. 167-187. Revista da Escola da Magistratura do Estado do Rio de Janeiro. v. 11, no 43. Rio de Janeiro, 2008.

ROUSSEAU, Jean-Jacques. "Discurso sobre a origem e os fundamentos da desigualdade entre os homens". In: MAFFETONE, Sebastiano; VECA, Salvatore (orgs). A idéia de justiça de Platão a Rawls. São Paulo: Martins Fontes: 2005. pp. 177-210. p. 185.

RUSSO, José. “As sociedades afetivas e sua evolução". In: Revista Brasileira de Direito de Família. Ano VII, no 32, out./nov. 2005. Porto Alegre: IOB Thomson, 2005. pp. 
40-49. p. 41.

SANDS, Philippe. “O princípio da precaução”. In: VARELLA, Marcelo Dias; PLATIAU, Ana Flávia Barros (coord.). Princípio da precaução. Belo Horizonte: Del Rey, 2004. pp. 29-46.

SARLET, Ingo Wolfgang. Dignidade da pessoa humana e direitos fundamentais na Constituição Federal de 1988. $8^{\text {a }}$ ed. Porto Alegre: Livraria do Advogado Ed., 2010.

A eficácia dos direitos fundamentais, $9^{\mathrm{a}}$ ed. Porto Alegre: Livraria do Advogado Ed., 2008.

SAVI, Sérgio. Responsabilidade civil por perda de uma chance. São Paulo: Atlas, 2006.

SCAFF, Fernando Campos. Direito à saúde no âmbito privado. Contratos de adesão, planos de saúde e seguro-saúde. São Paulo: Saraiva, 2010.

"Considerações sobre o Poder Familiar". In: CHINELLATO, Silmara Juny de Abreu; SIMÃO, José Fernando; FUJITA, Jorge Shiguemitsu; ZUCCHI, Maria Cristina. Direito de família no novo milênio. Estudos em homenagem ao Professor Álvaro Villaça Azevedo. São Paulo: Editora Atlas S.A., 2010. pp. 571-582.

SIMON, Jürgen. " Human dignity as a regulative instrument for human genome research". In: MAZZONI, Cosimo Marco (ed.). Ethics and law in biological research. The Hague/London/New York: Martinus Nijhoff Publishers/Kluwer Law International, 2002. pp. 35-45.

SILVA, Cláudia Maria da. "Indenização ao filho". In: Revista Brasileira de Direito de Família. v. 6, no 25, ago./set. 2004. Porto Alegre: Síntese, IBDFAM, 2004. pp. 122147.

SILVA, José Afonso da. Curso de Direito Constitucional Positivo. 33 a ed. Sâo Paulo: 
Malheiros Editores, 2010.

SILVA, Rafael Peteffi da. Responsabilidade civil pela perda de uma chance: uma análise do direito comparado e brasileiro. São Paulo: Atlas, 2007.

SILVA, Regina Beatriz da. "Pressupostos da responsabilidade civil na área da saúde". In: SILVA, Regina Beatriz Tavares da. Responsabilidade civil na área da saúde. São Paulo: Saraiva, 2007.

SILVA, Solange Teles da. "Princípio da precaução: uma nova postura em face dos riscos e incertezas científicas”. In: VARELLA, Marcelo Dias; PLATIAU, Ana Flávia Barros (coords.). Princípio da precaução. Belo Horizonte: Del Rey, 2004. pp. 75- 92.

SIQUEIRA, Maria Fernanda Santos. "Consentimento informado: o direito do paciente à informação, o respeito à sua autonomia e a responsabilidade civil do médico". In: Revista da ESMAPE, vol.13, n 27, jan./jun. 2008. Recife, 2008. pp. 377-409.

SOUZA, Rabindranath V. A. Capelo de. $O$ direito geral de personalidade. Tese(Doutoramento em Ciências Jurídicas pela Faculdade de Direito da Universidade de Coimbra). Coimbra: Coimbra Editora, 1995.

STEINBOCK, Bonnie; ARRAS, John D.; LONDON, Alex John. Ethical issues in modern medicine. $6^{\mathrm{a}}$ ed. Boston: McGraw-Hill, 2003.

SUSTEIN, Cass. "Para além do princípio da precaução". In: Interesse Publico. Ano VIII, n 37. Porto Alegre: Notadez Informação, 2006. pp. 119-171.

TEIXEIRA, Ana Carolina Brochado. "Responsabilidade civil e ofensa à dignidade humana". In: Revista Brasileira de Direito de Família. Ano VII, no 32, out./nov. 2005. Porto Alegre: IOB Thomson, 2005. pp. 138-158.

TEIXEIRA, Ana Carolina Brochado; PENALVA, Luciana Dadalto. “Autoridade parental, 
incapacidade e melhor interesse da criança. Uma reflexão sobre o caso Ashey". In: Revista de informação legislativa. Ano 45, n 180. Brasília: Senado Federal, 2008. pp. 293-304.

TEIXEIRA, Ivan Lobato Prado. Capacidade e consentimento na relação médico-paciente. Dissertação(Mestrado pela Faculdade de Direito do Largo São Francisco da Universidade de São Paulo). São Paulo, 2009. 210p.

TELlES, Marília Campos Oliveira; COLTRO, Antônio Carlos Mathias. "O Estatuto da Criança e do Adolescente: uma lei de gente grande”. In: Revista do Advogado. Ano XXVIII, nº 101, dez. 2008. São Paulo: AASP, 2008. pp. 70-76.

TENGAN, Cristiana; VENANCIO, Paulo César; MARCONDES, Fernanda Klein; ROSALEM, Pedro Luis. "Autonomia e vulnerabilidade do sujeito da pesquisa". In: Revista de Direito Sanitário. vol. 6, ns 1/2/3. São Paulo: LTr, 2005. pp. 25-37.

TOMÉ, Maria João Romão Carreiro. “Algumas considerações sobre a dependência”. In: CAMPOS, Diogo Leite de; CHINELLATO, Silmara Juny de Abreu (coords). Pessoa Humana e Direito. Coimbra: Almedina, 2009. pp. 295-348.

VASCONCELOS, Fernando A de. "A responsabilidade médica no Código de Defesa do Consumidor". pp. 33-54. Revista da Faculdade de Direito da Universidade Federal da Paraíba. Março de 1998. João Pessoa, 1998.

WOLFRUM, Rüdiger. "O princípio da precaução”. In: VARELLA Marcelo Dias; PLATIAU; Ana Flávia Barros (coords.). Princípio da precaução. Belo Horizonte: Del Rey, 2004. pp. 13-28. 